СИБИРСКОЕ ОТДЕЛЕНИЕ РАН

ИНСТИТУТ ЗЕМНОЙ КОРЫ

ИНСТИТУТ ГЕОЛОГИИ АЛМАЗА И

БЛАГОРОДНЫХ МЕТАЛЛОВ

ТЕХНИЧЕСКИЙ ИНСТИТУТ (ФИЛИАЛ)

СЕВЕРО-ВОСТОЧНОГО ФЕДЕРАЛЬНОГО УНИВЕРСИТЕТА

\title{
КАРТА СЕЙСМОТЕКТОНИКИ ВОСТОЧНОЙ СИБИРИ
}

Ответственные редакторы:

д.г.-м.н., профессор Г.С. Гусев,

д.г.-м.н., профессор И.И. Колодезников

Иркутск - Нерюнгри 


\section{Имаева Л.П.}

К27 Карта сейсмотектоники Восточной Сибири: монография / Л.П. Имаева, В.С. Имаев, О.П. Смекалин, Б.М. Козьмин, Н.Н. Гриб, А.В. Чипизубов. - Нерюнгри : Изд-во Технического института (ф) СВФУ, 2015. - 128 с.

Рассматриваются задачи, стадийность и содержание проведения сейсмотектонических исследований, как отдельного вида анализа комплексных геолого-геофизических материалов, используемых для установления тектонической природы проявлений местных землетрясений и связи с отдельныли неотектоническими структурами и современными геодинамическими процессами, протекающими на территории Восточной Сибири. Сейсмогеодинамический анализ проведен для сейсмогенерирующих зон Арктико-Азиатского и Южно-Сибирского сейсмических поясов, а также прилегающего сегмента шельфа арктических морей и активизированных структур Сибирского кратона. В наиболее сейсмически активных сегментах региона изучена структурно-тектоническая позищия основных эпищентральных полей $u$ палеосейсмогенных структур, выделены активные разломы, проведена магнитудная сегментация зон их динамического влияния, определены типы сопряжений активных структур. По степени активности и направленности геодинамических процессов разработаны региональные принципь классификации неотектонических структур с обоснованием дифференцииции их классов, выделены эталонные объекты в различных тектонических обстановках, в формате атрибутивных таблии даны их основные геологогеофизические и сейсмотектонические параметры. Результаты многолетних авторских исследований обобщены в карте сейсмотектоники Восточной Сибири, для которой дается краткое описание принципов и методов ее построения, приводятся наглядные примеры выделения активных разломов, палеосейсмогенных и неотектонических структур, тесно связанных с динамикой очаговых зон сильных землетрясений. Данный подход позволяет приступить к новому этапу исследований проблемы сейсмобезопасности, а созданные региональные сейсмогеодинамические модели могут быть использованы при уточнении исходного сейсмического балла существующих нормативных карт общего и детального сейсмического районирования. Публикация рассчитана на интерес со сторонь студентов, аспирантов, геологов, геофизиков, сейсмологов и инженеров-проектировщиков строительньх объектов 6 сейсмоопасных зонах.

Ключевые слова: сейсмотектонические исследования; сейсмическая опасность, активные разломы; тренчинг, неотектонические структуры, зонирование геодинамической активности, динамика очаговых зон сильных землетрясений, новые геоинформационные системы, сейсмогеодинамические модели, зоны ВОЗ, сейсмические пояса и их сегменты, карта сейсмотектоники Восточной Сибири.

\section{Рецензенты:}

Леви К.Г., д.г.-м.н., профессор, Институт земной коры СО РАН, г. Иркутск; Семенов Р.М., д.г.-м.н., профессор, Иркутский государственный университет путей сообщения

\section{Издание осуществлено при финансовой поддержке Министерства образования и науки РФ по гос. заданию № 5.1771.2014/к}

ISBN 978-5-91243-064-0 (с) Л.П. Имаева, В.С. Имаев, О.П. Смекалин,

Б.М. Козьмин, Н.Н. Гриб, А.В. Чипизубов, 2015

(C) Институт земной коры СО РАН, 2015 


\section{ОГЛАВЛЕНИЕ}

Введение.

Глава 1. Методика сейсмотектонических исследований

(задачи, стадийность и содержание).

Глава 2. Активные разломы сейсмических поясов Восточной Сибири................12

2.1. Активные разломы и оценка их сейсмического потенциала................... 12

2.2. Методы выявления активных разломов...................................... 17

2.3. Определение кинематики активных разломов...............................19

2.4.Установление зависимости возможной магнитуды землетрясений от длины и подвижки активного разлома......................................24

Глава 3. Изучение сейсмогенных структур Восточной Сибири.....................27

3.1. Анализ сейсмодеформаций в рельефе и при тренчинге......................27

3.2. Оценка возраста доинструментальных землетрясений.......................33

3.3. Сейсмодеформации Горно-Алтайского (Чуйского) землетрясения 2003 года...35

3.4. Палеосейсмодислокации Западного Саяна.................................41

3.5. Палеосейсмодислокации Прибайкалья....................................46

3.6. Палеосейсмодислокации Якутии........................................52

Глава 4. Неотектонические и сейсмогеодинамические исследования

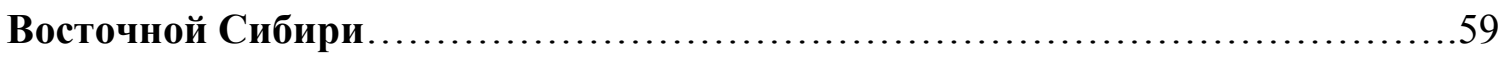

4.1. Главные принципы выделения геодинамически активных

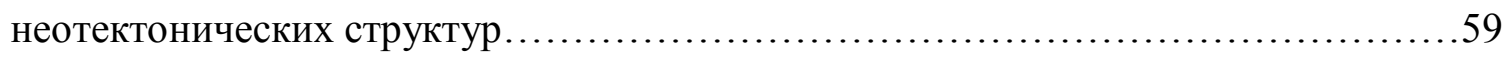

4.2 Составные элементы карты сейсмотектоники Восточной Сибири..............66

Глава 5. Структурно-динамические модели сейсмогенерирующих структур

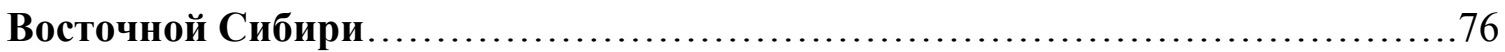

5.1. Южно-Сибирский сейсмический пояс...................................76

5.2. Арктико-Азиатский сейсмический пояс................................... 96

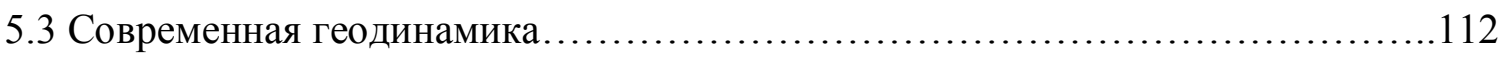

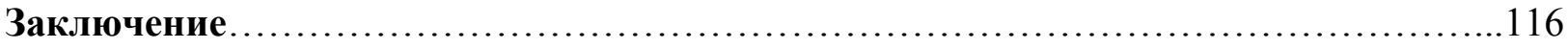

Литература....................................................................... 118 


\section{ВВЕДЕНИЕ}

При проведении работ по установлению вероятных связей разновозрастных геологических структур, а также разнообразных по своей позиции и структурному стилю тектонических элементов горно-складчатых областей Восточной Сибири с сейсмической опасностью, необходимо установить определенные закономерности в динамике разрывных структур и сейсмичности территории. Исследования подобного рода известны в российской и англоязычной научной литературе как самостоятельные сейсмотектонические исследования, главной целью которых являются: «...установление или изучение связи проявлений сейсмичности и тектоники регионов...» (Геологический словарь, 1993).

Другое, более развернутое определение сейсмотектоники приводится американскими учеными, которые утверждают, что сейсмотектоника «...является научной дисциплиной, изучающей взаимосвязь между землетрясениями, активной тектоникой и отдельными разломами региона. Стремится понять, какие данные несут ответственность за сейсмическую активность в конкретном районе путем анализа сочетания региональной тектоники, последних инструментально записанных сейсмических событий, исследования исторических и палеоземлетрясениях, а также неотектонические и геоморфологические данные. Эта информация в дальнейшем может быть использована для количественной оценки сейсмической опасности того или иного региона. При проведении сейсмотектонического анализа территории требуется интеграция большого количества разнородных геолого-геофизических данных...» (международное определение, C. Allen, 1975; R. Wallace, 1977; R. Yeats et al., 1997, J. P. MacCalpin, 2010).

Согласно практике проведения исследований подобного рода, сейсмические показатели используются для характеристики степени устойчивости геотектонического режима, определения зон контрастных тектонических движений, выявления доминирующих направлений подвижек. По глубине расположения очагов землетрясений, группирующихся в линии определенного простирания, судят о глубине заложения разрывов. Динамические параметры очагов дают сведения о величине и направлении сил, которые деформируют и разрушают горные породы. Результаты сейсмотектонических исследований выражаются обычно в виде сейсмотектонических карт, на которые наносятся данные о формах развития неотектонических структур и эпицентральные зоны землетрясений, что позволяет установить связь этих землетрясений с особенностями тектонического (неотектонического) строения местности и использовать эту связь для прогноза мест, силы и частоты землетрясений, а также для со- 
ставления карт сейсмического районирования (Горшков, 1975; Сейсмотектоника..., 1982; Имаев и др., 1990, 2000; Рогожин, Платонова, 2007; Рогожин, 2012).

Особые методические указания и руководства по проведению сейсмотектонических исследований отсутствуют. Наиболее полное обобщение методического характера выполнено более 20-ти лет назад и содержит весьма трудоемкий и дорогостоящий комплекс исследований (Аптикаев и др., 1986). Обзор методов сейсмотектонических исследований, отражающий в основном авторские представления, содержится в обобщении С.А. Несмеянова (2004). Отраслевые нормативы, в которых регламентируются требования к сейсмотектоническим исследованиям (к наиболее подробным можно отнести РД-91.020.00-КТН-042-12), содержат в основном перечень итоговых материалов и не раскрывают содержания исследований. Наиболее обстоятельно содержание таких исследований рассмотрено в нормах атомной отрасли (РБ-019-01).

Сейсмотектонические исследования до сих пор имеют слабое понимание сути и назначения исследований среди большинства специалистов сейсмологов. При этом они внесены в обязательный состав свода норм и правил по Общему сейсмическому районированию (СНиП, 2009). Отсутствие единого подхода и четкой регламентирующей базы часто не позволяет успешно провести сейсмотектонические исследования и ставит под сомнение результаты оценки уровня сейсмической опасности, полученные только методом инструментальных наблюдений. В данном обобщении кратко суммируется многолетний опыт проведения сейсмотектонических исследований в разных регионах сейсмоактивных структур территории Восточной Сибири, приводятся методические указания и обоснования целесообразности использования выбранных геолого-геофизических показателей для целей создания единой карты сейсмотектоники Восточной Сибири. 


\section{ГЛАВА 1. МЕТОДИКА СЕЙСМОТЕКТОНИЧЕСКИХ ИССЛЕДОВАНИЙ (ЗАДАЧИ, СТАДИЙНОСТЬ И СОДЕРЖАНИЕ)}

Как и во всех остальных исследованиях подобного рода, эффективность и достоверность результатов сейсмотектонических исследований во многом обеспечивается соблюдением последовательности или стадийности. В общем составе инженерно-геологических изысканий, сейсмотектонические исследования проводятся на завершающем этапе. Это связано с тем, что при оценке сейсмической опасности необходимы результаты инженерногеологических, геофизических, сейсмологических и геодезических работ. Совместно с сейсмологическими, сейсмотектонические исследования предваряют сейсмическое микрорайонирование. Сейсмотектонические исследования проводятся в три этапа.

На первом этапе проводится сбор исходного материала. Собственно исследования на этом этапе включают в себя совместный анализ всех имеющихся литературных и фондовых материалов по геологическому строению, сейсмическому режиму, неотектонике, истории развития рельефа, глубинному строению, напряженному состоянию и современным движениям земной коры, а также обязательное дешифрирование материалов дистанционного зондирования Земли (Д33). Иными словами, создается и анализируется имеющаяся региональная сейсмотектоническая база данных.

Bторой этап включает более конкретные исследования и связан, прежде всего, с обязательным полевым изучением активных разломов. Методика выявления и изучения активных разломов основана на комплексе дистанционных и структурно-геологических методов, позволяющих по проявлениям в рельефе и в составе молодых отложений выявить активный разлом и закартировать зону связанных с ним деформаций, а также определить тип, амплитуду и среднюю скорость смещений по разломам.

В состав обязательных полевых исследований входит:

- рекогносцировка, маршрутное структурно-геологическое и морфотектоническое (геолого-геоморфологическое) картирование участков активных разломов, установленных на изучаемой площади;

- выбор мест для детального изучения разломов в горных выработках и обнажениях;

- исследования зон разломов методами малоглубинной геофизики (высокочастотная сейсморазведка, электроразведочные работы, георадарная локация разломов);

- проходка и документация горных выработок (или тренчинг);

- изучение вторичных палеосейсмодислокаций;

- отбор образцов на абсолютное датирование в зонах разломов. 
Рекогносцировка подразумевает заверку и прослеживание по простиранию молодых тектонических деформаций, выявленных по дистанционным данным (аэрофото и космоснимки высокой степени разрешения). Маршрутное картирование выполнятся с целью обнаружения признаков позднеплейстоцен-голоценовых смещений, оценки возраста и генетической принадлежности смещенных по разлому форм рельефа, величины этих деформаций, оценки ширины влияния зон разломов по геоморфологическим и геологическим данным, а также для выявления других признаков возможной сейсмической активизации - вторичных (сейсмогравитационных) палеосейсмодислокаций. Геофизические исследования (сейсморазведка, электроразведка, георадарное и микросейсмическое зондирование) позволяют получить данные о строении разреза молодых отложений в процессе выбора мест для проходки горных выработок и оценить общую ширину зоны разлома.

Горные выработки проходятся с целью исследования проявлений разломных зон в молодых отложениях. Этот метод получил название тренчинга и широко используется в связи с изучением структуры активных разломных зон и восстановлением их сейсмической истории. Подробно методика изложена в работе (Палеосейсмология, 2011). Места для проходки горных выработок выбираются преимущественно по структурно-геоморфологическим соображениям. В этом отношении наиболее предпочтительными для заложения канав, шурфов и расчисток являются поверхности аккумуляции рыхлых позднеплейстоцен-голоценовых отложений, маркирующих собой опорные уровни, используемые для возрастной привязки деформаций. Оптимальными для изучения разломов являются канавы длиной в несколько десятков метров (в зависимости от конкретной ситуации) и глубиной 2-5 метра. Документация канав выполняется с целью выявления следов одноактных подвижек по разлому, оценки их кинематики, величины отдельных компонент подвижек, определения пространственных характеристик разлома (азимуты падения и простирания), т.е. данных, необходимых для расчетов по принятию мер защиты от возможных подвижек. Исследования подразумевают детальную зарисовку стенок канав в масштабе: 1:10, 1:20 или 1:50, расчленение разреза молодых отложений, прослеживание слоев с выявлением фрагментов земной поверхности прошлого, существовавшей на момент подвижки (подвижек), выявление и характеристику деформации этих фрагментов, и определение их возраста методами абсолютного датирования.

Результаты полевых сейсмотектонических исследований позволяют количественно охарактеризовать активные разломы. Такими характеристиками являются:

- местоположение, ширина зоны разлома;

- кинематический тип разлома;

- ориентировка и падение сместителя;

- скорость смещений по разлому на последнем этапе геологического развития района; 
- характер смещений (сейсмотектонический, криповый);

- одноактная амплитуда сейсмотектонических подвижек.

В случае отсутствия ярко выраженных активных разломов на поверхности, силу древних землетрясений можно восстановить по параметрам вторичных палеосейсмодислокаций. К таковым, в первую очередь, относятся размеры области, охваченной одновозрастными палеосейсмодислокациями.

Tpemuй этаn (камеральный) подразумевает завершающую обработку результатов как полевых, так и используемых обобщенных фондовых и литературных материалов. Результаты тренчинга используются при этом не только для установления мест пересечения проектируемых объектов с активными разломами, но и для построения сейсмотектонической модели. Основными элементами сейсмотектонической модели (карты зон ВОЗ) являются источники сейсмических воздействий - площадные (домены), характеризующие рассеянную (фоновую) сейсмичность и линейные, отражающие сосредоточенную сейсмичность, т.е. потенциальные очаги сильных землетрясений (сейсмолинеаменты по (Уломов, Шумилина, 1999)). Согласно сложившейся сейсмологической практике, в качестве линейных источников рассматриваются активные разломы. Материалы об активных разломах собираются как в результате специальных полевых исследований, так и по материалам предшественников, если таковые имеются.

Важнейшей составляющей сейсмотектонической модели являются прогнозные магнитуды землетрясений. Оценка максимально возможных магнитуд ожидаемых землетрясений производится по комплексу геолого-геофизических, сейсмологических и сейсмотектонических данных. Оценка магнитуды по комплексу сейсмотектонических данных основывается на глобальных статистических соотношениях между магнитудой землетрясения, протяженностью разрыва и величиной подвижки по нему (Палеосейсмология, 2011). Эти соотношения позволяют оценить магнитуду зоны ВОЗ по конкретным деформациям молодых отложений, параметры которых получаются в результате проведения полевых сейсмотектонических исследований.

Конечным итогом сейсмотектонических исследований является: создание сейсмотектонической модели региона; построение крупномасштабных карт зон возможных очагов землетрясений (ВО3) масштаба 1:1 000 000, 1:200 000-500 000; выделение активных разломов, оценка их параметров и точная привязка относительно проектируемых объектов народнохозяйственного назначения.

Сейсмотектонические исследования позволяют проводить детальную локализацию сейсмической опасности. В ряде случаев это приводит к существенному сокращению участков с высокой (8-9 баллов интенсивности) сейсмической опасностью по сравнению с карта- 
ми общего сейсмического районирования (ОСР), что соответственно удешевляет будущее строительство народно-хозяйственных объектов. В других случаях могут быть найдены новые, ранее неизвестные источники сейсмических воздействий и тогда уровень сейсмической опасности может быть повышен на локальных участках по сравнению с данными ОСР.

При проведении исследований очень важно соблюдение стадийности. Нарушение стадийности иногда может создать видимость сокращения сроков, но всегда отрицательно сказывается на результате. Учитывая нестандартный характер исследований, их выполнение целесообразно только при непосредственном участии специализированной научной организации, имеющей опыт в изучении активных разломов и высокую квалификацию картировочных работ.

Сейсмотектоническое районирование предусматривает разделение территории на области, где ожидаемые местные землетрясения будут настолько слабы, что не окажут воздействия на население и систему его жизнеобеспечения, включая инженерные сооружения (такие области считаются неспособными генерировать землетрясения и могут испытывать лишь сейсмические воздействия от удаленных сильных землетрясений); и области, способные генерировать коровые землетрясения, потому называемые зонами возникновения очагов землетрясений (BO3) и разделяемые по их максимальной возможной магнитуде и частоте. Выделение и параметризация, т.е. оценка сейсмического потенциала зон ВОЗ производится путем комплексного применения двух равноценных групп критериев: сейсмологической и геолого-геофизической.

Сейсмологическая группа включает в себя каталоги произошедших землетрясений: инструментальных, исторических и голоценовых палеособытий, выявляемые по геологическим и геоархеологическим данным, а также инструментальные и макросейсмические показатели распределения интенсивности сотрясений от ощутимых сейсмических событий. Они служат основой всех дальнейших картографических построений. Кроме того, исследования планового распределения эпицентров землетрясений, помимо оценки самих сейсмических воздействий, позволяет очертить очаговые области сильных землетрясений и, тем самым, уточнить геометрию зон ВОЗ. Вторым немаловажным фактором проявления и особенностей сильных землетрясений определенных районов служит информация о механизмах очагов сильных землетрясений, сводный анализ которых позволяет установить напряженнодеформированное состояние среды в тех или иных элементах геологической и неотектонической структуры. 


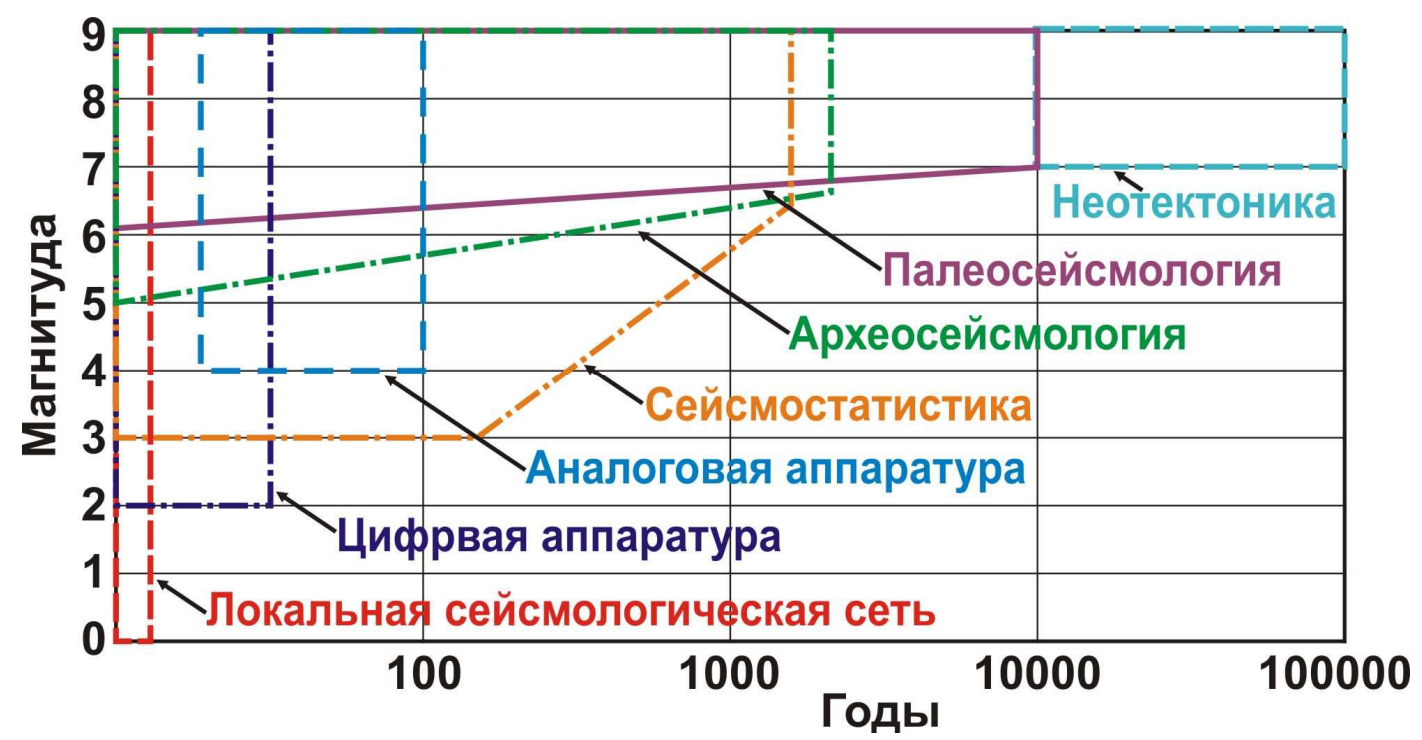

Рис. 1.1. Возможности использования различных методов изучения сейсмичности в зависимости от силы и времени землетрясения (Paleoseismology, 2009)

Обозначение комплекса методов к определению зон вероятных очагов землетрясений (BO3) определенной магнитуды, представляет одну из краеугольных задач современной сейсмотектоники (рис. 1.1). Применение геолого-геофизической группы критериев зон ВОЗ в настоящее время состоит в выделении и параметризации активных геологических структур, в которых землетрясения определенной магнитуды и частоты возникали в недавнем прошлом и потому могут ожидаться в близком будущем. Структурно-кинематические характеристики таких структур определяются геолого-геофизическими методами, тогда как оценка возраста проявлений их современной (недавней) активности производится методами геологического и геохронологического датирования с использованием результатов повторных геодезических измерений, среди которых ведущая роль принадлежит GPS наблюдениям.

Наиболее широко используемым для оценки сейсмической опасности типом активных структур являются активные (живые) разломы. Изучение соотношений магнитуд инструментальных землетрясений, с длиной возникавших при таких землетрясениях сейсмогенных разрывов земной поверхности и смещений по ним, позволило установить статистические соотношения между этими характеристиками, которые используются для оценки сейсмического потенциала активных разломов.

На основе комплексного использования и сопоставления сейсмологических данных (выявление, параметризация и кластеризация землетрясений, определение характеристик их повторяемости и формы очаговых областей) и геолого-геофизических характеристик активных структур (форма, кинематика, оценка сейсмического потенциала) производится картирование и параметризация зон ВОЗ двух типов: линейного и площадного (доменного) и решается проблема сейсмотектонического районирования. 
Линейные зоны ВОЗ в наиболее полном выражении представляют собой зоны активных разломов, к которым приурочены гипоцентры землетрясений. Очаговые области сильнейших из них вытянуты вдоль таких зон. При большой длительности временного интервала зарегистрированных землетрясений, иногда отмечается закономерная миграция гипоцентров вдоль зоны.

Зоны ВОЗ доменного типа, как правило, характеризуются более низким сейсмическим потенциалом, чем соседние с ними линейные зоны. Линейная упорядоченность очагов землетрясений в них отсутствует. Это может иметь разные причины. Во-первых, доменные зоны могут представлять собой совокупности разделенных асейсмичными участками линейных зон ВОЗ меньшего размера, которых не удалось обнаружить из-за слабого структурного выражения и/или недостаточной статистики сейсмических событий. Во-вторых, очаги землетрясений могут располагаться вдоль активной субгоризонтальной зоны разломов (зоны срыва или скольжения одного слоя земной коры по другому) и проектироваться на поверхность рассеянными эпицентрами. В-третьих, сейсмичность может быть приурочена к активной структуре неразломного типа - складке основания или объему земной коры с определенными свойствами, обусловливающими его сейсмическое разрушение, например, массиву.

Указанные задачи определяют два основных направления сейсмотектонических исследований и тесно взаимосвязаны между собой. Материалы полевого изучения активных разломов и вторичных эффектов древних землетрясений, наряду с другими сейсмотектоническими и сейсмологическими данными, ложатся в основу карты зон возможных очагов землетрясений (BО3), что представляется главной целью сейсмотектонических исследований (Трифонов и др., 1988; Рогожин, 2012; Имаев и др., 2000; R. Yeats et al., 1997). Поэтому, перед описанием конкретных результатов по сейсмотектонике территории Восточной Сибири, приведем основные определения и методы изучения активных разломов. 


\section{ГЛАВА 2. АКТИВНЫЕ РАЗЛОМЫ СЕЙСМИЧЕСКИХ ПОЯСОВ ВОС- ТОЧНОЙ СИБИРИ}

\section{1. АКТИВНЫЕ РАЗЛОМЫ И ОЦЕНКА ИХ СЕЙСМИЧЕСКОГО ПОТЕНЦИАЛА}

В конце 40-х годов XX века в геологической и сейсмологической литературе, соответственно американской и европейской, появились два термина-синонима - «активный разлом» и «живой разлом». Исследователи, которые ввели эти понятия в геологический обиход (Wallace, 1949; Толк. словарь, 1977-1978), назвали так разломы, выраженные на земной поверхности, демонстрирующие прямые или косвенные проявления современных тектонических движений и позволяющие тем самым предполагать подобную их подвижность в ближайшем будущем. Позднее, по аналогии с этими терминами, возникло более широкое по охвату структур понятие «активная тектоника» (Active tectonics, 1986).

На современную активность разломов обращали внимание и прежде. Еще в конце XIX века И.В. Мушкетов (1890) высказал соображения о связи землетрясений с разломами. Подробно описывались примеры активизации разломов при сильнейших землетрясениях - СанФранцисском 1906 г. в Калифорнии (Reid, 1910) и Кеминском 1911 г. в Тянь-Шане (Богданович и др., 1914). Но с середины XX в. резко возрос интерес к разломам, как источникам сейсмических и деформационных воздействий на существующие и возводимые сооружения и системы жизнеобеспечения, что сделало активные разломы специальным объектом исследований.

Помимо практического применения, изучение активных разломов и связанных с ними структурных новообразований имеет важное значение для понимания закономерностей и природы современных тектонических процессов территории. В сочетании с геофизическими и петролого-геохимическими данными, характеризующими современные процессы на глубинных уровнях геологической среды, активные проявления тектогенеза на земной поверхности позволяют построить трехмерные модели современного развития тектоносферы. Это может сделать более правдоподобными и доказательными палеотектонические и геодинамические реконструкции геологических событий недалекого прошлого.

Такое важное практическое и теоретическое значение активных разломов заставляет обратить особое внимание на методику их выявления и параметризации. Те или иные аспекты методики изучения активных разломов обсуждались неоднократно в отечественной литературе, хотя авторы таких работ на первых порах не называли эти проявления современного или недавнего разломообразования, активными разломами (Копп и др., 1981, 1997; Солоненко и др., 1968; Со- 
лоненко, 1973; Хромовских, 1981; Трифонов, 1983, 1985; Никонов, 1977; Nikonov, 1995; Трифонов и др., 2002; Трифонов, Караханян, 2004).

Большой вклад в развитие методики внесло изучение конкретных активных разломов, выполненное в разных регионах России и соседних стран, К.Е. Абдрахматовым, В.С. Буртманом, А.В. Ваковым, Т.П. Ивановой, В.С. и Л.П. Имаевыми, Р.М. Лобацкой, Н.В. Лукиной, В.И. Макаровым, Е.А. Рогожиным, В.А. Саньковым, К.Ж. Семинским, С.Ф. Скобелевым, А.Л. Стромом, С.И. Шерманом и другими. Однако до сих пор в отечественной литературе отсутствует целостное и последовательное изложение методики изучения активных разломов.

Поскольку движения по разлому происходят неравномерно и нередко дискретно (эпохи или моменты подвижек чередуются с эпохами покоя), для установления его активности необходимо изучить некий максимально приближенный к настоящему моменту временной интервал, в течение которого проявились бы не только факт активности разлома, но и его параметры (направление, скорость, режим движений и т.п.). Объем этого временного интервала является критическим и основополагающим в определении термина «активный разлом».

По мнению К. Аллена (Allen, 1975), активными следует называть разломы с признаками голоценовых (последние 10 тыс. лет) подвижек. А.А. Никонов (Nikonov, 1995) посчитал необходимым удлинить этот интервал времени до 400 тыс. лет, т.е. отнести к нему также весь поздний и средний неоплейстоцен. Исследования, специально выполненные в Альпийско-Гималайском поясе и на западе США для оценки длительности обсуждаемого интервала времени, показали, что приразломные проявления голоцена и позднего неоплейстоцена (последние 100-130 тыс. лет) необходимы и достаточны для определения активен или нет разлом (Трифонов, 1983, 1985).

Это заключение согласуется с оценками периодов повторяемости подвижек по разломам, с которыми связаны сильные землетрясения. Теоретически, при сохранении свойств нарушенных разломом пород (в его крыльях), неизменности скорости перемещения разделяемых разломом блоков и сохранении общей геодинамической ситуации в регионе, должен оставаться неизменным и период повторяемости подвижек и вызываемых ими землетрясений. Если со времени последней подвижки миновало времени меньше характерного периода повторяемости, то правомерным будет полагать, что подвижка по разлому возможна в геологически недалеком будущем и считать, таким образом, изучаемый разлом активным. И наоборот, значительное превышение продолжительности сейсмического «молчания» разлома после последней подвижки характерного периода повторяемости, дает основание отнести разлом к неактивным. Периоды повторяемости землетрясений в подвижных областях и зонах континентов, выявленные при изучении конкретных разломов, колеблются в пределах от первых сотен до первых тысяч лет, но могут достигать и гораздо больших величин. Так, например, для разлома Умехара в Японии установлен средний период повторяемости подвижек примерно в 14.5 тыс. лет (Kumamoto, 1998). Разумеет- 
ся, говоря о периоде повторяемости подвижек и землетрясений, имеют в виду некое среднее его значение.

Поэтому в целях надежности заключений целесообразно оперировать не единичным, а двойным или тройным интервалом повторяемости, что приводит к тем же цифрам порядка 100 тыс. лет - «Технический регламент проведения работ по общему сейсмическому районированию территории Российской Федерации (ОСР)» (Строит. нормы и правила, 2000). В относительно стабильных регионах (континентальные и океанические платформы и внутриплитные орогены типа Урала или Восточного Казахстана) из-за вялости тектонических движений и редкости землетрясений подобный временной интервал должен включать весь неоплейстоцен, т.е. последние 700 тыс. лет (Трифонов и др., 1993).

Авторы Проекта II-2 «Карта крупных активных разломов Мира» Международной программы «Литосфера» дифференцировали активные разломы по времени последних подвижек, показав разными символами разломы с последними проявлениями активности: (1) - в историческое время, (2) - позднем неоплейстоцене-голоцене и (3) - раннем-среднем неоплейстоцене (среднем плейстоцене в американско-европейской терминологии) (Trifonov, 1995). Такое понимание и ранжирование активных разломов представляется нам оптимальным. Существенно, что оно учитывает и требования строителей АЭС к оценке активности разломов. МАГАТЭ предлагает учитывать подвижки по разломам в течение последних 0.5 млн. лет, а, согласно российским нормам, этот интервал должен достигать 1 млн. лет. В российских условиях, когда нижнесреднеплейстоценовые отложения местами не отделяются от эоплейстоценовых (нижнеплейстоценовых в западной терминологии), а иногда и верхнеплиоценовых, к последней группе активных разломов приходится предположительно относить разломы, выраженные в таких недифференцированных отложениях.

Возможно, что наиболее четкое определение понятия «активный разлом» приведено в «Рекомендациях по оценке эксплуатационных качеств нефте-и газопроводов при природных опасных процессах и событиях, угрожающих людям» (Guideline for Assessing the Performance of Oiland Natural Gas Pipeline Systemsin Natural Hazardand Human Treat Events), подготовленных Национальным институтом строительных наук в 2005 г. (American Life line Alliance. FEMA National Institute of Building Sciences. Reportand Commentary). Согласно этому документу «Активный разлом-это сейсмогенный разлом, который, вероятно, испытает обновление за период времени, когда это может представлять опасность для общества. Разломы обычно рассматриваются, как активные, если подвижки по ним происходили хотя бы один раз за последние 10000-11 000 тысяч лет, но может также считаться потенциально активным при оценке опасности для некоторых случаев (видов сооружений), даже если подвижка про- 
изошла в течение последних 500000 лет». В этом же документе перечислены методы, применяемые при поиске и изучении активных разломов:

1 - анализ имеющихся карт активных разломов территории (при их наличии);

2 - анализ топографических карт;

3 - анализ стереоскопических аэрофотоснимков (при их наличии);

4 - полевое обследование (выполняется квалифицированным геологом);

5 - изучение активных разломов в траншеях;

6 - оценка величин смещений по разрывам с использованием эмпирических методов;

7 - определение подвижек по разломам и вероятности их возникновения с проходкой траншей, отбором образцов, их датированием и анализом.

Предположим, что по некоторому разлому установлены подвижки с периодичностью примерно один раз в 2 тыс. лет, и что последняя подвижка произошла около 10 тыс. лет назад. При этом движений по разлому не было в течение периода времени, включившего несколько средних периодов повторяемости (рис. 2.1, вариант А). В таком случае вероятность возникновения новой подвижки за срок службы сооружения (30-50 лет) очень мала и можно рассматривать такой разлом, как неактивный. Если же при той же повторяемости подвижек последняя из них произошла, скажем, 500 лет назад, то есть время, прошедшее после этого события меньше среднего периода повторяемости или близко к нему, (рис. 2.1, вариант Б) вполне вероятно, что за ней последуют другие и разлом следует считать активным. Следует отметить, что вариант А слишком гипотетичен, так как в таком случае средняя повторяемость подвижек будет уже намного меньше 2000 лет (порядка 6000 тысяч лет).

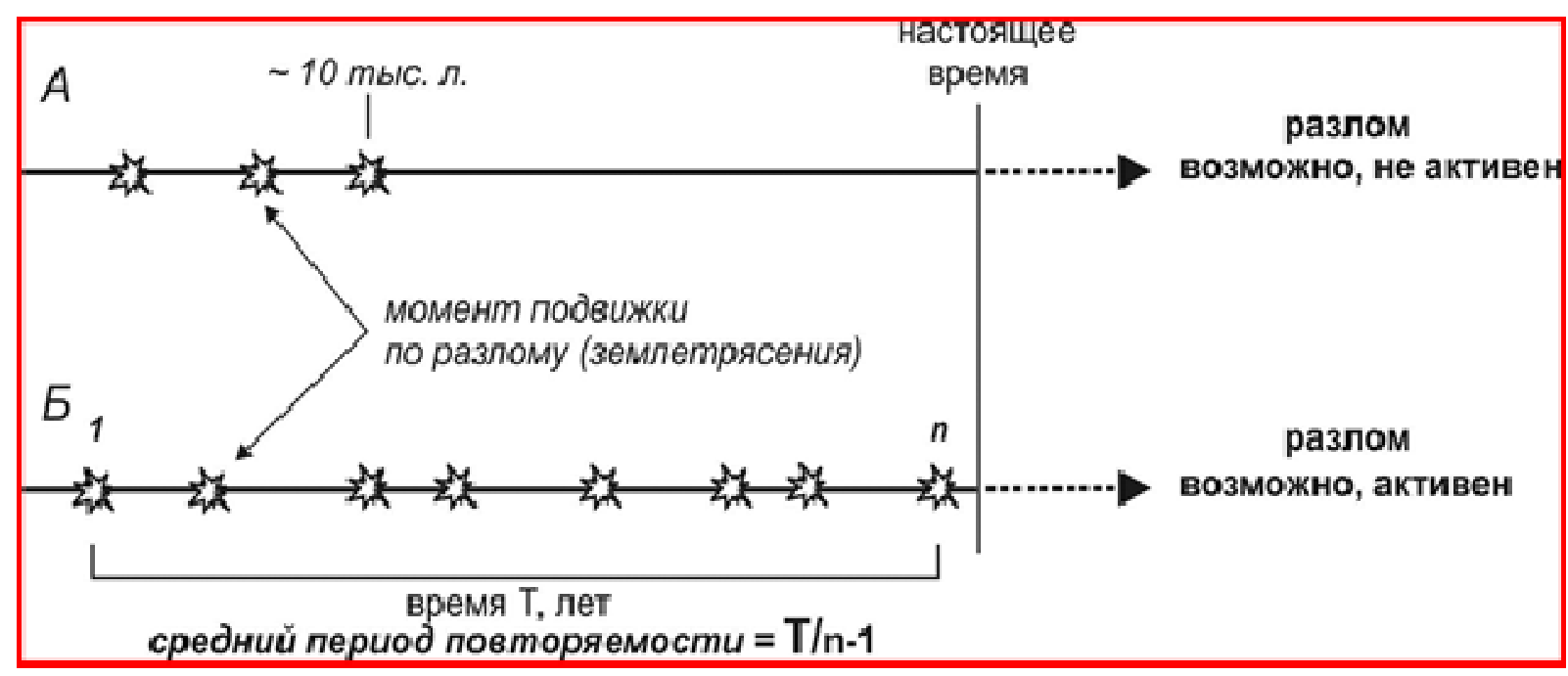

Рис. 2.1. Идеальная схема подвижек по активному (А) и неактивному (Б) разломам. (Схема представлена А.Л. Стромом)

Принятый в идеальной схеме период повторяемости в 2000 лет вполне реален, хотя известны разломы и с гораздо более продолжительными промежутками времени между под- 
вижками. Так, например, для разлома Умехара в Японии установлен средний период повторяемости подвижек примерно в 14-15 тыс. лет. Сделав поправку на возможную неполноту данных, примем в качестве максимального интервал примерно в 20000 лет. Для полной уверенности удвоим или даже утроим это значение. В итоге, можно заключить, что максимальная продолжительность искомого интервала (периода накопления напряжений между сейсмогенными подвижками по активному разлому) может составлять десятки тысяч лет, охватывая весь голоцен плюс некоторую часть позднего плейстоцена. Такая оценка интервала, очевидно, близка к периоду, предложенному В.Г. Трифоновым $(1983,1985,1999)$ для подвижных областей (100-130 тысяч лет).

Методика выявления, параметризации и картирования активных разломов основана на комплексе совместных аэрокосмических и наземных полевых (заверочных) методов, позволяющих по проявлениям в рельефе и молодых отложениях опознать активный разлом, закартировать зону связанных с ним нарушений и деформаций, определить режим (тип, величину, среднюю скорость перемещений и степень дискретности проявлений движений во времени). Большое значение для уточнения указанных характеристик имеет изучение структурных проявлений сильных землетрясений в зоне разлома. Основным методом поиска и картирования активных разрывов, примененным при составлении карты активных разломов исследуемой территории, было дешифрирование космических снимков. Следует только подчеркнуть, что это лишь первый этап, за которым должен обязательно следовать второй, предусматривающий дешифрирование крупномасштабных (обычно 1:50000-1:10000) аэрофотоснимков и космоснимков.

В качестве активных выделялись нарушения, отчетливо выраженные в рельефе в виде прямолинейных, дугообразных или фестончатых уступов протяженностью в сотни метров километры и высотой в первые метры, иногда в первые десятки метров, которые пересекают и смещают мелкие формы рельефа и поверхности выравнивания голоценового (позднечетвертичного) возраста, а также синхронные им отложения. Поскольку в большинстве случаев сейсмогенные разрывы возникают в зонах длительно развивающихся разломов, особое внимание уделялось «подозрительным» формам рельефа в зонах крупных тектонических нарушений, в первую очередь тех, которые ограничивают или примыкают к рифтовым впадинам Байкальской рифтовой зоны (БРЗ). Активные разломы, отчетливо выраженные в рельефе в виде уступов или горизонтальных сдвигов в пределах БРЗ и её горно-складчатого обрамления рассматривались как сейсмогенные, образовавшиеся при резких смещениях при сильных землетрясениях. По совокупности своих морфологических особенностей и по морфоструктурной приуроченности они аналогичны разрывам, образовавшимся при Муйском землетрясении 1957 г. с магнитудой М=7.6 и при многочисленных землетрясениях в Провинции Бас- 
сейнов и Хребтов на западе США (в штатах Невада, Монтана, Айдахо), являющейся достаточно близким тектоническим аналогом БРЗ.

В конечном счете, несмотря на большие возможности использования дистанционных материалов, принятие решения о современной (позднечетвертичной) активности разлома обычно не заканчивается на этом этапе, а требует полевой проверки, по меньшей мере, на отдельных участках разлома.

\section{2. МЕТОДЫ ВЫЯВЛЕНИЯ АКТИВНЫХ РАЗЛОМОВ}

Методика выявления, параметризации и картирования активных разломов основана на комплексе аэрокосмических и наземных методов, позволяющих по проявлениям в рельефе и в молодых отложениях, опознать активный разлом, закартировать зону связанных с ним нарушений и деформаций, определить тип, величину и среднюю скорость перемещений, а также режим - тип и степень дискретности проявлений движений во времени. Большое значение для уточнения указанных характеристик имеет исследование структурных проявлений сильных землетрясений в зоне разлома.

В данном разделе рассматриваются методы распознавания и картирования активных разломов. Предварительное решение этой задачи основано на анализе, во-первых, сосредоточенной сильной сейсмичности (подразумевается, что линии эпицентров приурочены к активным разломам) и, во-вторых, неотектонических данных. Последние представляют собой синтез данных структурной геологии, изучения рельефа и молодых отложений и показывают суммарные деформации новейшего этапа структурообразования, которые, в зависимости от интенсивности блоковой тектоники и выраженности их в современном рельефе региона, характеризуются разной степенью геодинамической активности этих структур в регионе, охватывает разное время от олигоцен-четвертичного до плиоцен-четвертичного.

Поэтому, существенным для решения задачи становится определение тенденций неотектонического развития территории. Но даже после выявления элементов новейшей структуры, характеризующихся признаками поздней подвижности, и обнаружения пространственной приуроченности к ним эпицентров землетрясений, сохраняется неопределенность и неполнота решения. Иногда их удается устранить анализом детальных материалов аэрокосмической съемки, выделяя на них разрывы, нарушающие поверхность молодых отложений и форм рельефа. Критериями активных разломов являются дешифрируемые на изображениях линейные зоны ландшафтных контрастов или полосовые ландшафтные аномалии, представляющие особенности рельефа, рисунка дренажной сети, обводненности, растительности. 
На стадии изучения неотектонической зональности использование космических снимков позволяет наметить структурные элементы и зоны, в которых вероятно существование активных разломов. Убедительные свидетельства активности могут быть обнаружены на космических снимках не мельче 1:200 000. Подчеркнем, что это лишь первый этап, за которым должен обязательно следовать второй, предусматривающий дешифрирование крупномасштабных (обычно 1:50000-1:10000) аэрофотоснимков и космоснимков. Часто выполняется площадное дешифрирование не только выделенных зон, но и окружающей территории, поскольку так можно обнаруживать на земной поверхности, помимо собственно разломов, другие, в том числе нетектонические, проявления землетрясений прошлого (например - сейсмогравитационные). По существу, дешифрирование аэрофотоматериалов, особенно в стереоскопическом изображении, представляет наиболее эффективный практический способ обнаружения активных разломов.

С чем связана необходимость использования крупномасштабных съемок земной поверхности? Дело в том, что при характерных средних скоростях перемещений по континентальным разломам от первых миллиметров до (редко) первых сантиметров в год и периодах повторяемости импульсных разломных подвижек в первые сотни лет - первые тысячи лет, накопленные за голоцен или позднечетвертичное время амплитуды вертикальных, сдвиговых или комбинированных смещений относительно молодых (например, голоценовых) элементов земной поверхности не превышают единиц - первых десятков метров. Нередки случаи, когда величина смещения, скажем, поверхности и тылового шва террасы не превышает 0.5-1 м - величины одной сейсмогенной подвижки по разлому. Очевидно, что обнаружение такого смещения требует крупномасштабных материалов высокого разрешения. Эффективную помощь может оказать использование георадара.

При несомненном наличии некоторых общих черт у всех активных разрывных деформаций, интерпретация форм рельефа, в смысле и возможной обусловленности движениями по разломам или отсутствия связи с ними, каждый раз конкретна. Следует, однако, иметь в виду несколько общих правил такой интерпретации:

1 - следует убедиться, что формирование некоторой линейной формы рельефа не может быть объяснено действием нетектонических (эрозионных, денудационных, мерзлотных и т.д.) процессов;

2 - должно наблюдаться прямое соответствие между величиной накопленных разломных деформаций и возрастом смещаемых элементов рельефа;

3 - как правило, линия предполагаемого активного разлома должна находить отражение в материалах геологической съемки. Известны, однако, случаи, когда даже на недавно изданных геологических картах масштаба 1:200 000 линия доказанного активного разлома представлена как обычный стратиграфический контакт; 
4 - предполагаемый разлом должен логично «вписываться» в систему новейших структур района.

Несмотря на отмеченные возможности использования дистанционных материалов, принятие решения о современной (позднечетвертичной) активности разлома обычно требует полевой проверки, по меньшей мере, на отдельных участках разлома. Ее целью является обнаружение признаков активности в тех или деформациях рельефа и молодых отложений. Наилучшие результаты дает изучение пересекаемых разломом речных долин (изменения их формы, продольного профиля, количества, высоты и разреза террас). В соответствующих ландшафтногеологических условиях активные разломы могут проявляться приуроченностью к ним вулканических построек, мелких озер, родников, линейными очертаниями побережий крупных озер и морей, изменениями морфологии побережий и деформацией террас, распределением заболоченных участков и разных типов растительности, отражающих условия обводненности (Трифонов, 1999, 2001).

Указанные выше прямые методы могут дополняться данными геофизики, газогидрогеохимии и повторной геодезии. Так, признаком потенциальной активности является присутствие в зоне разлома изостатической аномалии. В областях с мощным чехлом рыхлых отложений эффективный и иногда решающий результат дает приповерхностная сейсморазведка и электроразведка. В ряде случаев, особенно при вялости молодых движений, признаками активности могут быть термальные, газовые и гидрогеохимические аномалии. Неоднократно отмечалась в литературе приуроченность к активным разломам гелиевых и радоновых аномалий.

\section{3. ОПРЕДЕЛЕНИЕ КИНЕМАТИКИ АКТИВНЫХ РАЗЛОМОВ}

В публикациях неоднократно обсуждалась информативность аэрокосмических снимков для определения кинематического типа активного разлома. Предварительные соображения о типе разлома могут быть получены анализом структурного рисунка разломной зоны (Трифонов, 1985, Трифонов и др., 1997; Имаева и др., 2010). На рис. 2.2 представлены зоны сбросов, надвигов и сдвигов на мелкомасштабном изображении территории Тувинского и Саянского сегментов Южно-Сибирского сейсмического пояса с разрешением на местности 100 м. 


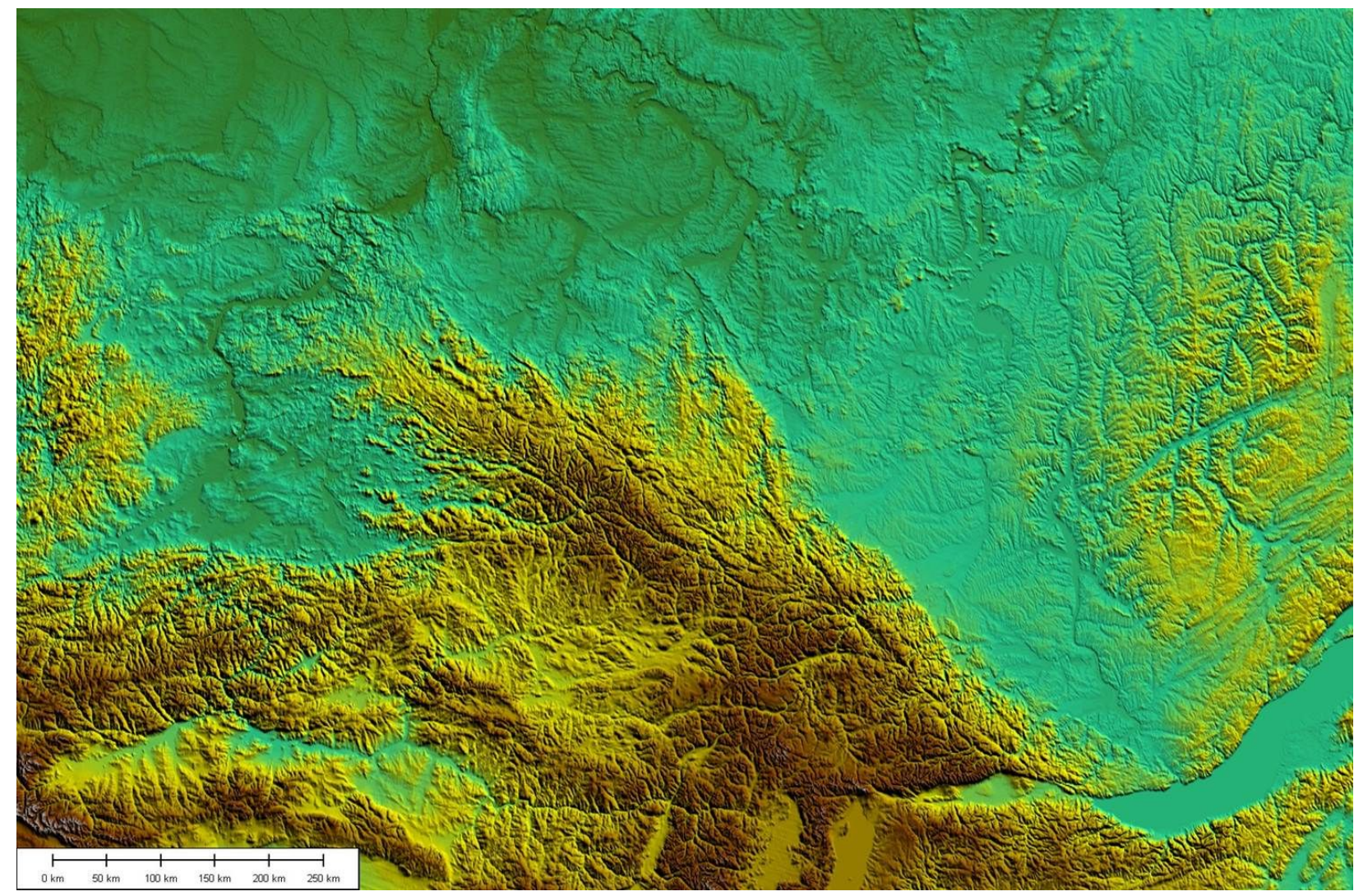

\section{Рис. 2.2. Пример цифровой модели рельефа, на которой отчетливо видны кинематиче- ские типы активных разломов, в частности Главный Саянский разлом}

Сдвиги наиболее прямолинейны и на значительном протяжении их зоны компактны, хотя нередко осложнены оперяющими нарушениями. Они могут быть представлены сдвигами, простирающимися под очень острым углом к основному нарушению (сколы Риделя) или простирающимися под бо́льшим углом сбросами и раздвигами. Оперяющими по отношению к сдвигу могут быть и ряды примыкающих к нему структур сжатия - надвигов, взбросов и молодых складок. Их простирание отличается примерно на $90^{\circ}$ от простирания оперяющих структур растяжения. Кулисные ряды простирающихся под углом к основному сдвигу более мелких сдвигов Риделя или разрывов сжатия или растяжения особенно характерны для его окончаний. Сбросовые зоны отличаются значительной шириной и состоят из ряда сравнительно непротяженных нарушений, расположенных беспорядочно, но простирающихся в одном направлении. В вулканических областях к ним могут быть приурочены цепочки вулканических аппаратов. Надвиговые зоны нередко имеют дугообразный (выпуклый в направлении надвигания) фестончатый рисунок. Характерно омоложение разрывов в направлении надвигания, причем, как показывают геофизические данные и анализ гипоцентрии землетрясений, такой ряд надвигов может на глубине сливаться в единую поверхность срыва.

Сочетание сдвига с оперяющими структурами сжатия и растяжения в миниатюре может повторяться в сейсмогенных нарушениях, возникающих в зонах разломов при сильных землетрясениях. Там сдвиг может выражаться в плане ступенчатым сочетанием бугров выдавливания и рвов растяжения или кулисным рядом структур одного из этих типов. Последнее чаще наблюдается в области затухания сейсмогенной подвижки. Вместе с тем, крупные 
сдвиги нередко состоят из сегментов, расположенных эшелонировано друг относительно друга. В результате сдвигового перемещения между сегментами возникают осложняющие структуры (дуплексы), которые, в зависимости от относительного положения окончаний соседних сегментов, характеризуются условиями либо дополнительного сжатия, либо растяжения.

Такие структуры растяжения, где сдвиги приобретают сбросовую компоненту перемещений и сочетаются по сбросам и раздвигами, часто выражены вытянутыми вдоль зоны разлома впадинами, называемыми pull-apart. В отличие от них, приразломные дуплексы с дополнительным сжатием нередко выражены в рельефе молодыми поднятиями (Sylvester, 1988), но могут образовывать и приразломные вдавленные (рамповые) впадины, если данная область была депрессией еще до начала разломообразования. Такие вдавленные структуры называются впадинами push-inside (Трифонов, Караханян, 2004).

Ярким примером взаимоотношения крупных сдвиговых разломов сейсмогенной природы в горной системе Черского служат сдвиги Улахан и Дарпир прослеживаемые в обрамлении Омулевского блока (рис. 2.3). Разломы отчетливо трассируются на дистанционных аэрофото и космоснимках и представляют собой разломы, с которыми пространственно связаны отдельные землетрясения. Примечательно то, что кинематика движения по этим двум сопряженным сдвигам (с левой компонентой движения - Улахану и правостороннему сдвигу Дарпиру) подтверждается не только комплексом проведенных здесь детальных структурногеологических исследований, но находится также в полном динамическом соответствии с формированием отдельных морфоструктур и решениями фокальных механизмов очагов землетрясений (Имаев и др., 2000).

Чаще всего, линия активного разлома, независимо от его кинематики, дешифрируется на поверхности как уступ некоторой, часто варьирующей по простиранию разлома, высоты. Даже чисто сдвиговые разломы создают уступы в рельефе: нарушаемые поверхности разного генезиса всегда имеют тот или иной наклон и никогда не являются абсолютно горизонтальными, так что при их сдвиговой деформации совмещенными на одной поперечной к разлому линии оказываются их разновысотные участки. Также распространенным, в связи с появлением разломного уступа в рельефе, является заложение вдоль линии разломов ложбин, наличие которых помогает диагностировать активные сдвиги. 


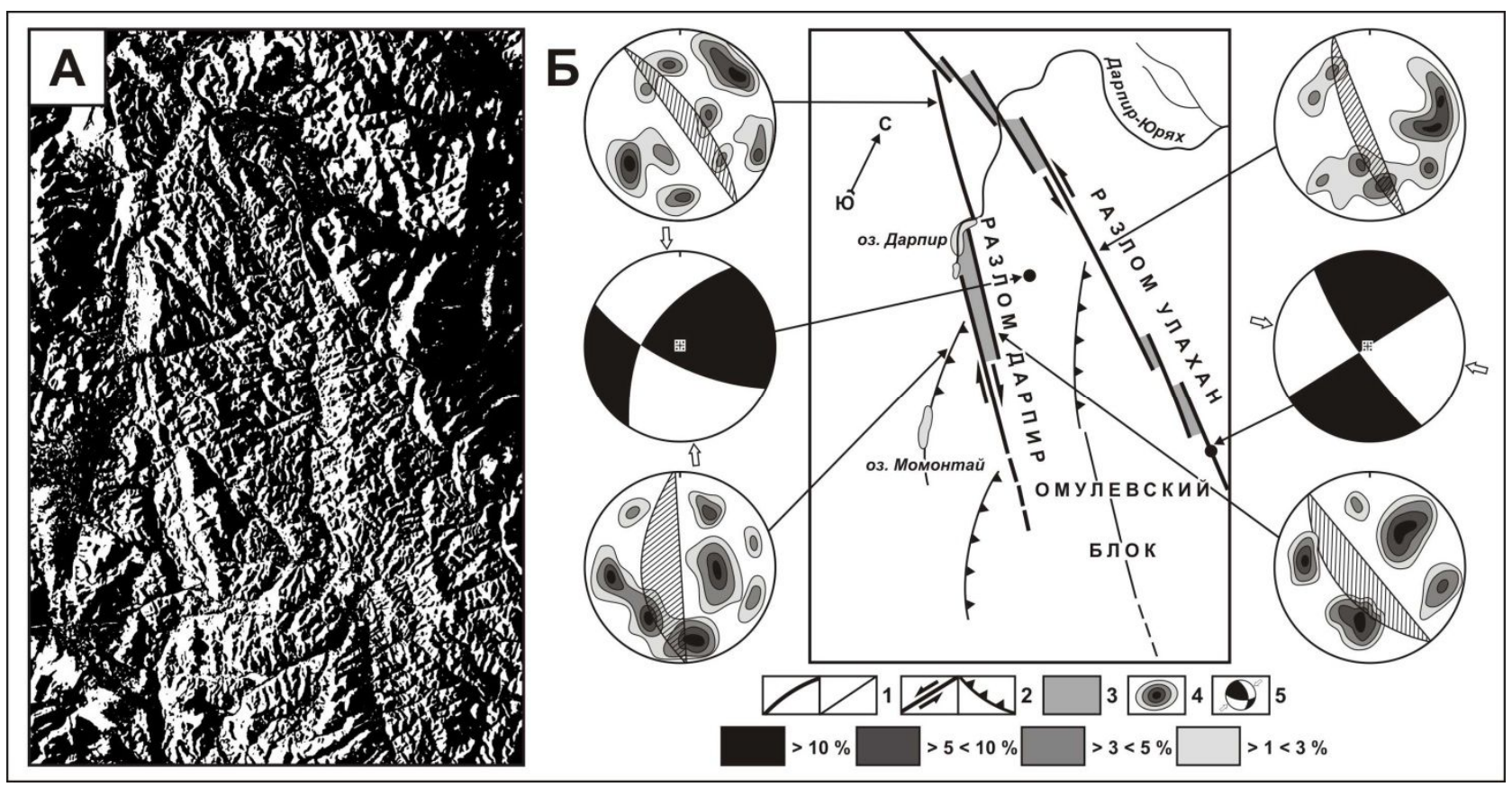

Рис. 2.3. Космоснимок Омулевского блока (А) и фрагмент его дешифрирования (Б) 1 - разломы: генеральные и локальные; 2 - сдвиги и надвиги; 3 - приразломные впадины типа «риll-apart»; 4 - диаграммы трещиноватости горных пород, штриховкой показано положение рабочей плоскости разлома; 5 - фокальные механизмы землетрясений (черная область растяжение, белая - сжатие), стрелками показана ориентачия напряжений сжатия

Дешифрирование крупномасштабных аэрокосмических снимков с разрешениями в метры и десятки метров устанавливает более конкретные признаки активных разломов разного типа. Так, по степени искривления линии разлома на пересечении со средне - и позднечетвертичными формами рельефа различаются крутые и пологие нарушения. По систематическому искривлению русел более или менее уверенно выделяются сдвиговые смещения и оценивается их амплитуда. Разные амплитуды смещения долин и их элементов разного времени заложения указывают на длительность движений. Таким примером является сейсмодислокация Бэрис, которая служит северным продолжением Аата-Суохской сейсмогенной структуры по трассе Хараулахского разлома и представлена прямолинейным секущим разрывом субдолготного простирания длиной 12 км, со сдвиго-сбросовым кинематическим типом движения (рис. 2.4). Смещения некоторых форм рельефа указывают на их преобладающий правобоковый характер. Сейсморвы приурочены к компактному блоку сжатия, аномально развернутому по часовой стрелке к северо-востоку. Несмотря на яркую выраженность основной трассы разлома, на аэрофотоснимках не дешифрируются свежие сейсмотектонические и сейсмогравитационные проявления. 


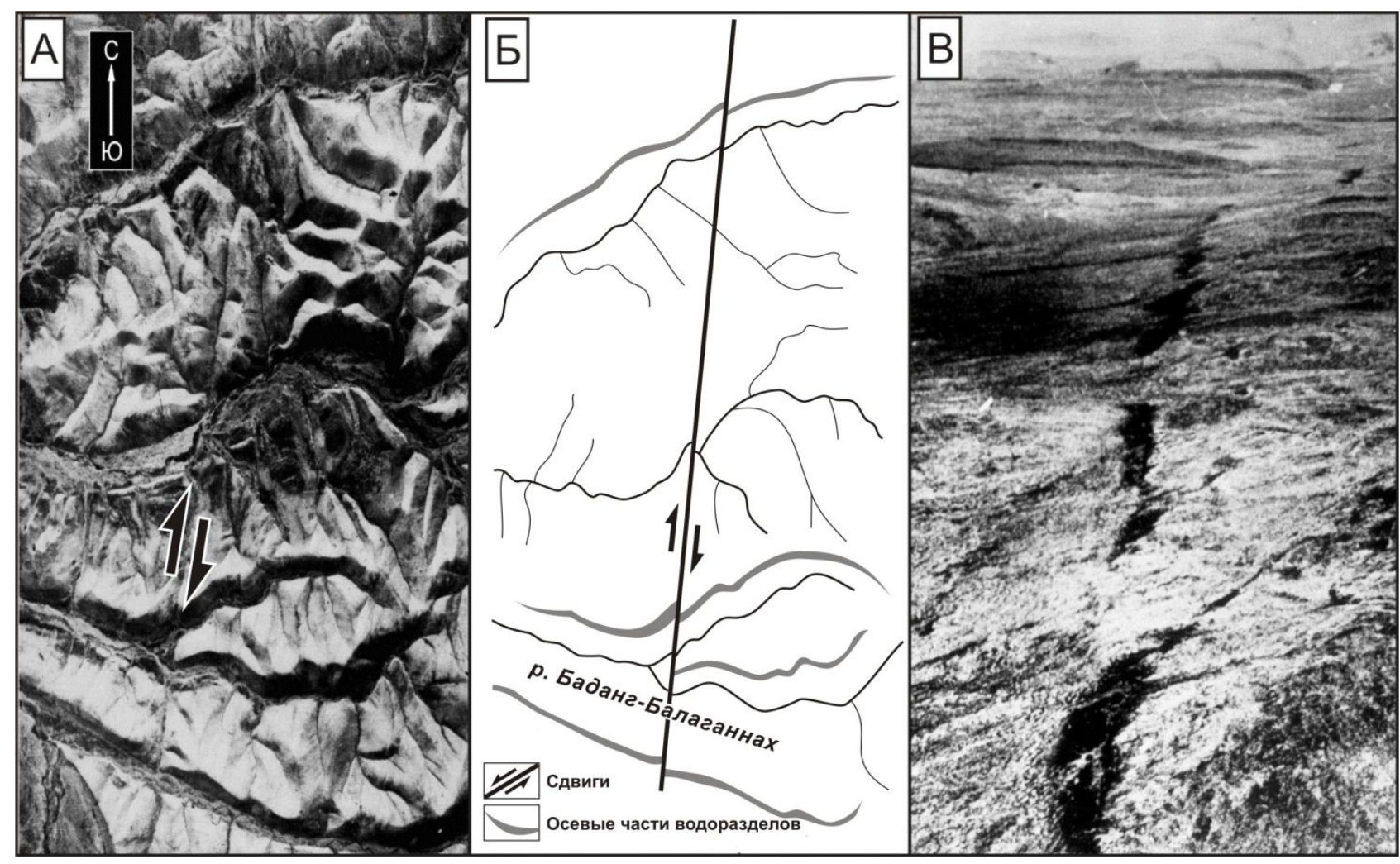

Рис. 2.4. Сейсмодислокация Бэрис

A - аэрофотоснимок сейсмодислокации в виде активного разлома, вскрытого на земной поверхности при Булунских землетрясениях 1927-1928 г2. Стррелками показана плоскость разлома. Б- фрагмент дешифрирования данного снимка. В - сейсмогенные трещины растяжения, фиксируемые в зоне Хараулахских разломов, где возникла сейсмодислокация «Бэрис»

При натурных наблюдениях обнаружено, что разлом представляет собой систему шириной 10-15 м. На склонах и вершинах водоразделов он выражен в виде ложбин шириной 46 м, внутри которых встречаются обломки аргиллитов и песчаников, перетертых в мелкую крошку. Края рвов-ложбин поднимаются крутыми (80-90) отвесными стенками над их днищем на 2.0-2.5 м и сложены преимущественно обломками окварцованных плотных песчаников. Направление движения крыльев данного разрыва уверенно устанавливается по смещению субширотных притоков рек, а также осевых линий водораздельных хребтов. Амплитуда горизонтального смещения западного крыла этого разрыва составила 25-30 м. Смещением оказались затронуты самые молодые отложения флювиогляциального комплекса вплоть до пойменных и надпойменных террас. Указанные сведения, а также анализ трещиноватости пород в плоскости выявленного разлома позволили определить его кинематику как правый сдвиго-сброс. По комплексу сейсмогеологических возраст сейсмодислокации Бэрис оценен нами первой тысячью лет при расчетной магнитуде землетрясения 7.0-7.5. 


\section{4. УСТАНОВЛЕНИЕ ЗАВИСИМОСТИ ВОЗМОЖНОЙ МАГНИТУДЫ ЗЕМЛЕТРЯСЕНИЯ ОТ ДЛИНЫ И ПОДВИЖКИ АКТИВНОГО РАЗЛОМА}

В основе использования активных разломов для оценки $\mathrm{M}_{\max }$ зоны ВОЗ лежат эмпирические соотношения между $\mathrm{M}_{\max }$ и длиной разлома L. Они основываются на уравнении регрессии вида $\mathrm{M}=\mathrm{a}+\mathrm{b} \operatorname{lgL}$, рассчитанном по данным о случившихся землетрясениях, сопровождавшихся возникновением сейсмогенных разрывов. Коэффициенты a и b существенно варьируют в разных регионах и для Земли в целом (Bonilla et al., 1979; Slemmons et al., 1986; Чипизубов, 2008). Наиболее полной сводкой данных, по которым можно судить о соотношениях $\mathrm{M}$ и $\mathrm{L}$, а также $\mathrm{M}$ и $\mathrm{D}$ - величиной сейсмогенной подвижки, сейчас признается работа (Wells, Coppersmith, 1994), по которой обычно и выполняются подобные расчеты. Н.В. Шебалин (Shebalin et al, 2000) выразил зависимость между Mmax и L в графической форме, которая использовалась при общем сейсмическом районировании (ОСР) Северной Евразии и, в частности, России (ОСР-97).

Важное значение приобретает также более тщательное обоснование сегментации крупных разломных зон. Эти зоны, как правило, генерируют землетрясения посегментно (сверхсильные землетрясения типа Чилийского 1960 г. или Аляскинского 1964 г., охватившие несколько сегментов, являются исключениями и не могут приниматься в расчет), и при расчете соотношений $\mathrm{M}_{\max } / \mathrm{L}$ учитывается не общая длина зоны, а длина сегмента. Обоснование сегментации активных зон разломов основано на их детальном картировании и геологогеофизическом изучении особенностей строения.

Полученные эмпирические зависимости между магнитудой землетрясения М и сейсмогенной подвижкой D выражаются уравнением регрессии, подобным приведенному выше для соотношения M/L, хотя данные об отдельных событиях дают больший разброс. Однако основная трудность использования этого соотношения для оценки $\mathrm{M}_{\max }$ состоит не в этом разбросе, а в том, что смещения, выявленные при землетрясениях инструментального периода или приписываемые исследованным палеоземлетрясениям, могут быть меньше смещения, которое способно произвести максимальное для данной активной зоны землетрясение. Лишь для отдельных хорошо изученных разломов в благоприятных ландшафтно-геологических условиях удается разделить суммарное смещение за определенный интервал времени на сумму индивидуальных сейсмогенных подвижек. Идентификация возможно большего ряда смещений при палеоземлетрясениях приближает к оценке максимальной возможной сейсмогенной подвижки. И если длина активного разлома позволяет оценить верхний предел $\mathrm{M}_{\max }$ данной зоны, то выявляемые сейсмогенные подвижки - ее нижний предел. 
Что же касается кинематического типа разлома, то в последние годы появились новые данные о его значении для определения $\mathrm{M}_{\max }$. Было показано (Трифонов, 1985; Трифонов и др., 1997), что при одинаковых магнитудах $\left(\mathrm{M}_{\mathrm{s}}\right)$ землетрясений, сдвиговый тип подвижки приводит обычно к образованию более протяженного сейсмогенного разлома, чем сбросовый тип, а сбросовый сейсмогенный разлом оказывается, как правило, длиннее надвига или взброса. К близким выводам пришли А.Л. Стром (1993) и А.В. Ваков (1992), причем последний, анализировал соотношения магнитуд с размерами очаговой области землетрясений разного кинематического типа, которые определялись по совокупному критерию распространения сейсмогенных разрывов и афтершоков землетрясения.

Исследовались также соотношения магнитуд $\mathrm{M}_{\mathrm{s}}$ с величинами максимальных Dmax и средневзвешенных Dav сейсмогенных смещений по разломам, возникшим при землетрясениях разного кинематического типа (Стром, 1993; Стром, Никонов, 1997). При большом разбросе полученных значений обнаружена тенденция к тому, что величины сбросовых подвижек возрастают более резко с ростом магнитуд, чем подвижек надвиго-взбросового типа, причем это более заметно для величин средневзвешенных смещений, чем максимальных. Цитируемые авторы связывают это с влиянием силы тяжести, наращивающей величину подвижки при сбросовом типе движений. Возрастание Dav сдвига с ростом магнитуд близко или немного выше, чем у сброса, при существенно меньшем разбросе данных (Стром, Никонов, 1997). При этом Dav сдвигов достигают бо́льших значений, поскольку магнитуды сильнейших сдвиговых землетрясений превосходят 8, тогда как магнитуды сбросовых землетрясений более 7.8 неизвестны (рис. 2.5).

Как для внесения поправок в соотношения $\mathrm{M}_{\max } / \mathrm{L}$, так и для оценки количества учитываемых сейсмогенных подвижек по разлому за определенное время при расчете соотношений $\mathrm{M}_{\max } / \mathrm{D}$, решающее значение приобретает определение интенсивности (средней скорости) движений по активному разлому. Она рассчитывается тремя способами: геологическим, сейсмологическим и геодезическим.

Геологическая оценка определяется геолого-геоморфологическими методами (иногда с применением данных приповерхностного сейсмопрофилирования) и получается делением определенной амплитуды смещения на интервал времени, в течение которого оно произошло. Полученная величина представляет собой среднюю скорость движения за этот интервал. Поскольку в течение геологически длительных отрезков времени, измеряемых сотнями тысяч и, тем более, миллионами лет, структура региона, особенно подвижного, заметно эволюционирует, для определения современной средней скорости движений рискованно использовать интервалы времени, превышающие поздний плейстоцен-голоцен или, в крайнем случае, четвертичный период. 


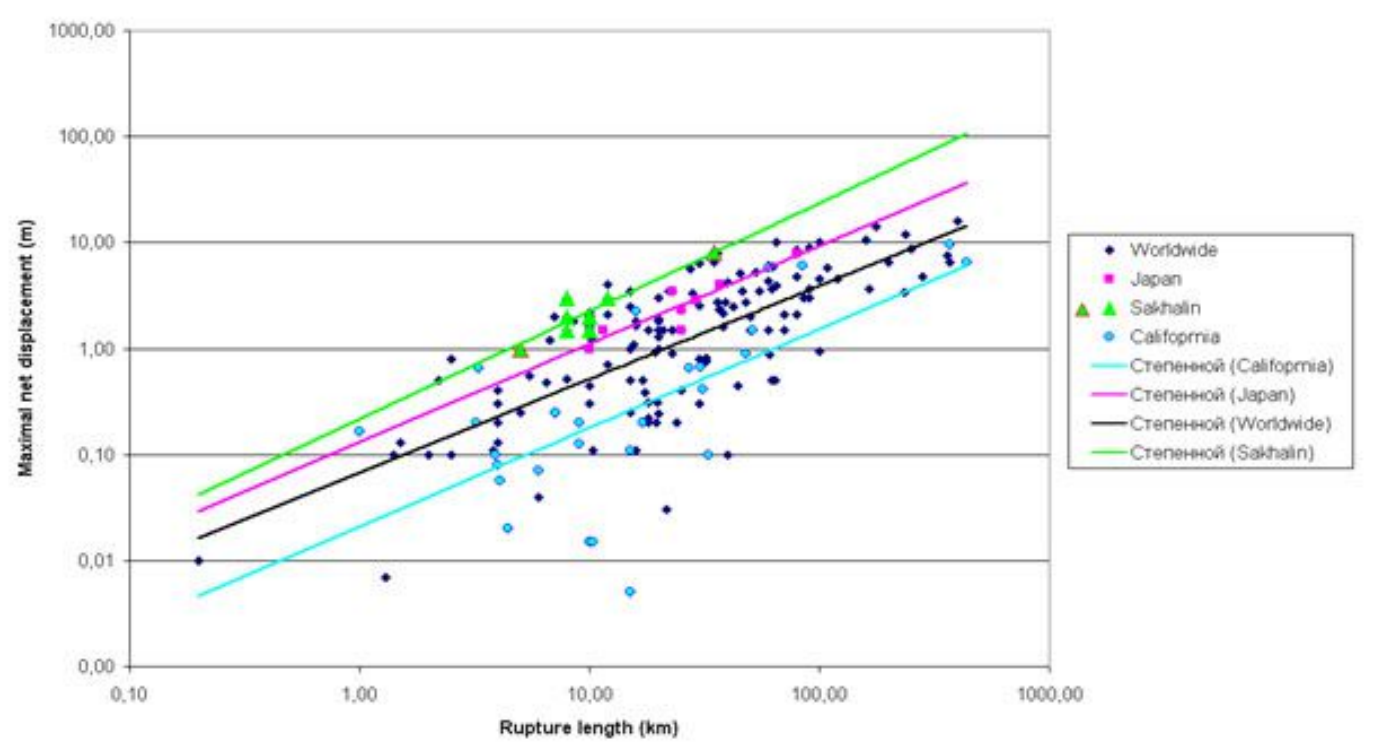

Рис. 2.5. Соотночение максимальных смещений по направлению подвижки $\left(D_{\max }\right) u$ протяженности сейсмогенных разрывов в зависимости от выборки (по (Стром, 1993)) Worldwide - мировые данные (166 событий); Јарап - сейсмогенные разрывы Японии (8 событий); Sakhalin - сейсмогенные разрывы Сахалина (обрамленные треугольники - разрывы Нефтегорского и Углегорского землетрясений; однотонные треугольники - палеосейсмогенные разрывы в висячем крыле Ключевского разлома); California - сейсмогенные разрывы Калифорнии (27 событий). Приведены графики степенных зависимостей вида $D_{\max }=a \times L^{b}$

Поскольку одним из главных доказательств сейсмической активности разломов, являются устанавливаемые в зонах динамического влияния следы сейсмопроявлений и развитие палеосейсмогенных структур (ПСД), то методам их анализа и их пространственному распространению посвящен специальный раздел настоящей работы. 


\section{ГЛАВА З. ИЗУЧЕНИЕ СЕЙСМОГЕННЫХ СТРУКТУР ВОСТОЧНОЙ СИБИРИ}

\section{1. АНАЛИЗ СЕЙСМОДЕФОРМАЦИЙ В РЕЛЬЕФЕ И ПРИ ТРЕНЧИНГЕ}

Палеосейсмологические исследования решают две основные задачи, имеющие важное практическое и теоретическое значение. Одна из них, направленная на установление величины самих палеособытий, касается выделения одноактных и приблизительно одновозрастных палеосейсмодислокаций (ПСД). Вторая связана с определением морфо-кинематических типов активных разломов, по которым происходили эти разрывообразующие палеоземлетрясения. Последнее имеет значение как для определения величины палеоземлетрясений, так и для геодинамических построений или иначе сейсмогенеза территории.

Первая задача может быть успешно решена при проведении детальных работ с массовым вскрытием сейсмогенных микроформ рельефа траншеями и отбором проб на радиоуглеродный анализ. Однако это потребует огромных финансовых затрат. С меньшими затратами данную задачу можно разрешить обычными структурно-геологическими и геоморфологическими методами.

Следующей задачей является выделение разновозрастных подвижек возможно по изменению углов наклона или перегибам (bevelscrest) сейсмогенных уступов. На возможность выделения количества палеособытий по заметным перегибам в поперечных профилях сейсмогенных уступов указывал Р. Уоллес еще тридцать лет назад. В последние годы анализ морфологии сейсмогенных уступов для выделения количества палеособытий стал широко применяться в практических целях (Deng, Liao, 1996; Sanders, Slemons, 1996).

На завершающем этапе определяется возможность разделения многоактных сейсмотектонических уступов появляется в местах пересечения сейсмогенными разрывами долин рек и ручьев с террасовыми комплексами. Здесь следует ожидать отражения разновозрастных вертикальных импульсных подвижек в количестве и высоте террас, обусловленных врезами в результате изменившегося базиса эрозии от этих подвижек. Вышеуказанный подход стал применяться в последнее время во многих регионах мира (Brogan et al., 1991; Deng, Liao, 1996).

Если первые два признака могут и не всегда наблюдаться, то глубина и количество врезов водотоков неизбежно проявляются и однозначно указывают на количество и масштаб сейсмотектонических подвижек, обусловивших изменение местного базиса эрозии.

За более чем 40-летний срок сейсмогеологических исследований в Восточной Сибири 
накоплен довольно обширный материал, свидетельствующий о влиянии сильных палеоземлетрясений на формирование рельефа территории. Из первичных сейсмогенных форм рельефа, приуроченных к узкой полосе выхода сместителя (разрыва) на поверхность, здесь преобладают эскарпы, рвы и плоскодонные грабены, расположенные цепочкой и сопряженные между собой трещины растяжения и валы сжатия, а также надразломные флексурообразные складки. По обе стороны от линии разлома и на значительном удалении возможно развитие вторичных проявлений палеоземлетрясений, вызванных сотрясением грунта. Со стороны горного обрамления - это сели, обвалы. На привпадинных крыльях сотрясение проявляется в виде просадок грунтов, изменения дебита источников. Вторичные проявления, как правило, не имеют весомого значения в палеосейсмической практике, так как могут быть связаны с землетрясениями, не вызывающими вспарывания поверхности $(\mathrm{M}<6)$. Влияние на перестройку рельефа оказывает и само перемещение крыльев разлома в процессе реализации землетрясения. В результате таких движений изменяются русла рек, возникают или, наоборот, осушаются озера и болота, меняются контуры береговых линий, уровни поверхностных и грунтовых вод. В горных районах с этапами сейсмической активизации тесно связано развитие террасовых комплексов.

Геологические методы палеосейсмологических исследований направлены на решение трех главных задач: обнаружение следов сильных палеоземлетрясений в зонах разломов, определение их повторяемости и определение их магнитуд. В ходе исследований возникает четвертая задача - отделить сейсмогенные подвижки по разлому от крипа, для решения которой также разработаны определенные методические приемы.

Чтобы использовать соотношения Mmax/D для оценки Mmax, необходимо определить величины смещений при землетрясениях прошлого. Для выявления следов сильных исторических и доисторических землетрясений в зонах активных разломов решающее значение имеет «тренчинг» - вскрытие разломных зон горными выработками и, прежде всего, поперечными канавами. Тренчинг представляет специальный способ изучения активных разломов, направленный на выявление и датирование подвижек по разлому, величины одноактных подвижек и периода их повторяемости. Итогом является получение данных о примерной магнитуде связанных с подвижками палеоземлетрясений, времени последнего палеоземлетрясения и периоде повторяемости палеоземлетрясений. Очевидно, речь идет именно о сильных землетрясениях, о чем свидетельствует сам факт достижения сейсморазрывом (разрывом очага) земной поверхности. Существует несколько общих правил, которым необходимо иметь в виду при тренчинге:

1 - тренчинг - не способ поиска, а метод изучения уже обнаруженных предваряющими исследованиями разломов; 
2 - наиболее результативны канавы, заложенные в тех точках на линии разлома, где в обоих его крыльях происходило накопление молодых отложений - аллювиальных, морских, озерных. Возможность датирования подвижек снижается, если накопление отложений, примерно соответствующих по возрасту подвижкам, происходило лишь по одну сторону от разлома, либо они не накапливались вовсе;

3 - предпочтительнее для тренчинга участки поверхности, амплитуда смещений которых минимальна среди наблюдаемых, в идеале - оказывается равной величине одноактной подвижки: в таких случаях вероятность того, что канава достигнет следов подвижек, предваряющих последнюю, максимальна;

4 - в общем виде, изучение и интерпретация разрезов в стенках траншеи основана на анализе фаций и мощностей отложений и, в итоге, выделении стратиграфических единиц и их корреляции между крыльями разрыва.

Особенностью наблюдаемых на земной поверхности и изучаемых в стенках канавы импульсных подвижек по разлому является то, что они каждый раз происходят вблизи земной (свободной) поверхности. Практически мгновенное формирование разломного уступа может сопровождаться (но не всегда и лишь при наличии вертикальной компоненты смещений) появлением трещин разваливания уступа или его обрушением сформированием обвальной массы, называемой коллювиальным клином. Затем, в течение какого-то времени, происходит накопление отложений увеличенной мощности в опущенном крыле и уменьшенной (до отсутствия) в поднятом, чаще при подвижке в водной среде.

Коллювиальные клинья - прислоненные к разломному уступу и выклинивающиеся с удалением от него линзы несортированного обломочного (нередко грубообломочного) материала. По составу клин соответствует коренным породам и покровным отложениям, залегавшим прежде на склоне выше разломного уступа, и является продуктом их катастрофического переотложения, которые связывают с сильным сейсмическим событием. Иначе говоря, клин, в отличие от отложений, смещенных сейсмогенным разрывом и перекрывающих его, точно соответствует моменту землетрясения (рис. 3.1).

Каждой подвижке соответствует свой комплекс вторичных структур и отложений, по возрасту перекрывающих ее. Расшифровка соотношений разновременных комплексов, а затем их датирование и позволяет восстанавливать последовательность, величину и возраст подвижек и связанных с ними сильных землетрясений. При этом полезным является использование такого понятия, как событийный горизонт (eventhorizon), который, в идеале, представляет собой некоторую поверхность, возраст которой «равен» возрасту подвижки (землетрясения). Один из первых удачных примеров подобных исследований в мировой литературе 
приведен в работе К. Си (Sieh, 1978), вскрывшего зону разлома Сан-Андреас в долине руч. Паллет.

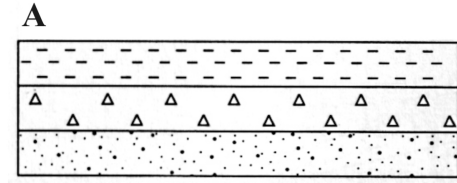

В (Событие 1)

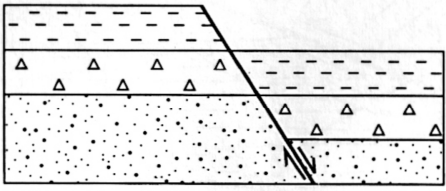

С (Формирование коллювиального

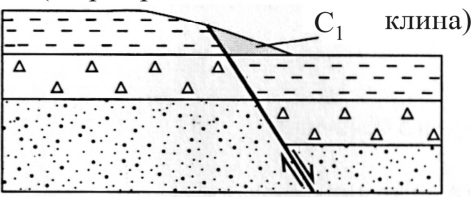

D (Событие 2)

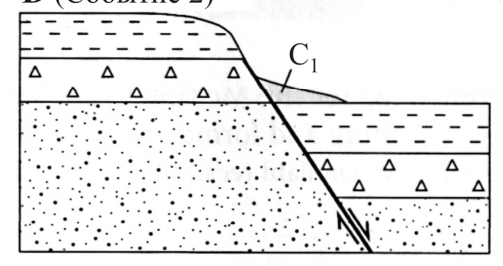

$\mathbf{E}$ (Формирование коллювиального

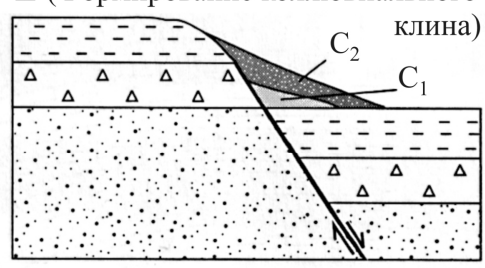

F (Событие 3)

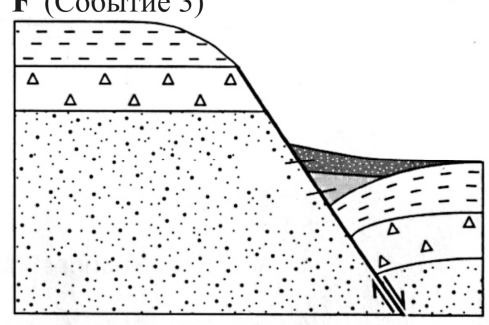

$\mathbf{G}$ (Формирование коллювиального

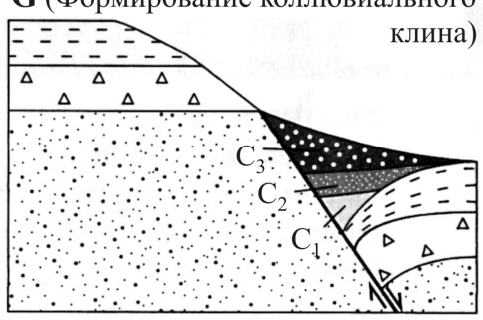

Рис. 3.1. Схема развития сейсмотектонического уступа в результате трех палеособытий, предложенная Дюс. МакКалпиным (Paleoseismology, 1996)

Каждое новое разрывообразование устанавливается по сформированному коллювиальному клину $C 1, C 2$ и $C 3$

Существуют и другие, помимо «тренчинга», методы регистрации палеоземлетрясений, хотя обычно получаемые с их помощью результаты менее определенны. Так, Р.Е. Уоллес (Wallace, 1977) показал, что ломаный профиль сбросового уступа может указывать на сейсмическую дискретность вертикального смещения, при которой крутизна соответствующей части склона зависит от длительности его эрозии, т.е. возраста подвижки. По данным Р.Е. Уоллеса, полученным в западной части Большого Бассейна США, выполаживание уступа происходит как за счет эрозии его верхней части, так и аккумуляции продуктов разрушения внизу. Самые свежие уступы, не древнее первых тысяч лет, характеризуются в рыхлых отложениях наклоном $\sim 35^{\circ}$ и резким изломом в верхней части. Уступы, возникшие 12 тыс. лет назад, имеют наклон 20-25, а более древние уступы выполаживаются до 8-9; при этом постепенно сглаживается верхний излом уступа. Указанные наклоны разновозрастных уступов нельзя безоговорочно экстраполировать в другие регионы, поскольку наклоны зависят как от литологии осадков, так и климатических условий. Однако общий подход может быть 
использован в каждом регионе отдельно для возрастного разделения уступов не только сбросовых, но и возникающих в зонах надвигов и взбросов.

Сейсмическая импульсность сдвиговых перемещений по активному разлому может быть выявлена по дискретности амплитуд горизонтальных смещений форм рельефа в рассматриваемом сегменте разлома (Wallace, 1980, 1987; Трифонов, 1985; Trifonov et al., 1995). Метод основан на том, что в зоне разлома непрерывно формируются все новые пересекающие его мелкие водотоки. Со временем большинство их исчезает (сменяется новыми подобными формами), а часть закрепляется в виде устойчивых элементов дренажной сети. Иначе говоря, среди существующих сейчас форм, количество водотоков убывает по мере удревнения времени их заложения. Если по разлому происходили непрерывные сдвиговые перемещения, на гистограмме соотношения амплитуда смещения - количество смещенных водотоков, будут представлены все амплитуды на фоне убывания больших амплитуд, накопившихся за длительное время. Если движения по разлому происходили в виде сильных сейсмических импульсов, разделенных эпохами полного или относительного тектонического покоя, на гистограмме будут представлены лишь некоторые амплитуды, соответствующие подвижкам при одном, двух, трех и т.д. землетрясениях, а промежуточные значения амплитуд будут отсутствовать или их количество окажется редуцированным.

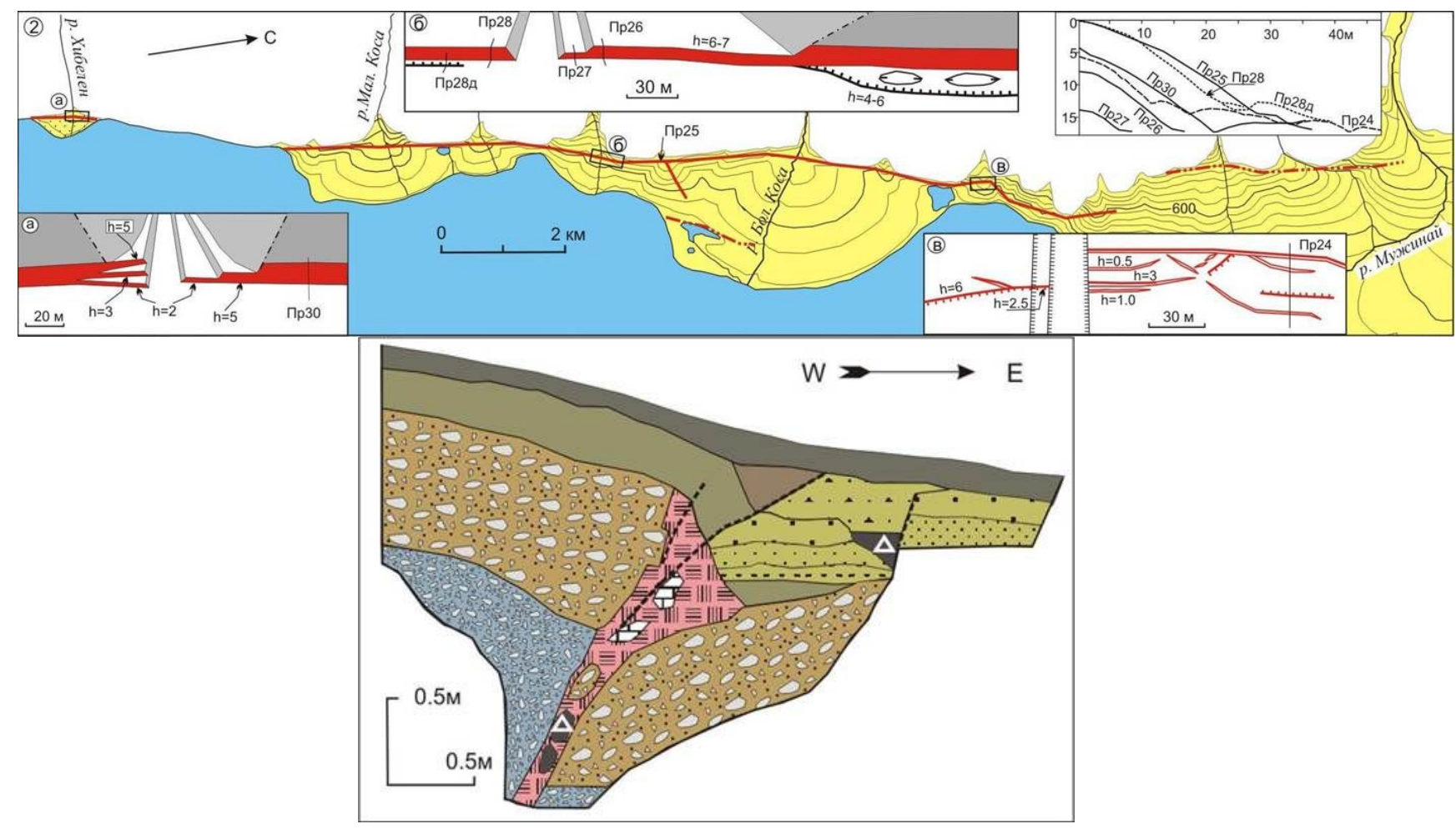

Рис. 3.2. Пример проведенных тренчинговых работ в районе Северобайкальского разлома На верхней схеме показано детальное картирование и морфометрия, на нижнем-схематический разрез канавы 
Косвенными свидетельствами сильных палеоземлетрясений и соответственно объектами, изучением которых можно определить возраст события, являются крупные приразломные оползни (особенно с большими величинами их горизонтального перемещения относительно вертикального спуска), сейсмогенные изменения береговых линий и пр. Примером проведенных тренчинговых работ могут служить приводимые ниже разрезы в плоскостях крупных структурообразующих разломов Байкальской рифтовой зоны - Северобайкальского и Баргузинского (рис. 3.2, 3.3).
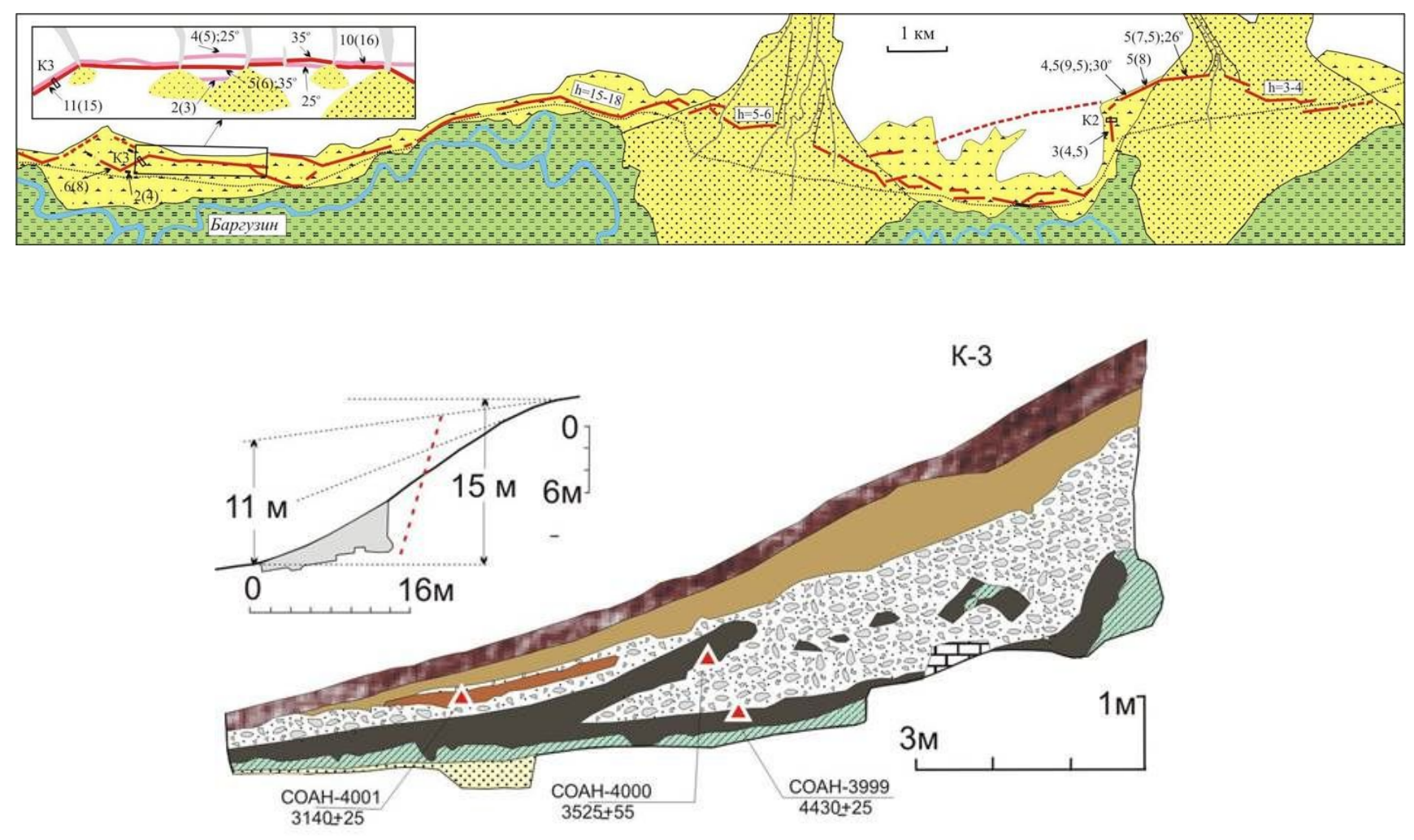

Рис. 3.3. Пример документации сейсмогеологических работ в зоне Баргузинского разлома (Чипизубов и др., 2000)

Верхняя часть рисунка - детальео картирование сейсмогенных дислокаций в зоне разлома. На нижнем рисунке представлена документаџия канавы с указанием расположения радиоуглеродных возрастов и положения канавы на профиле сейсмогенного

Показательны также и исследования, проведенные на северном побережье оз. Байкал, где пройденные траншеи вскрыли Кичерский активный разлом, к которому приурочена одноименная палеосейсмодислокация. Характер деформаций в пределах зоны разлома покзан на разрезе, а местоположение и внешний вид канавы - тренгчинга приведен ниже (рис. 3.4). 

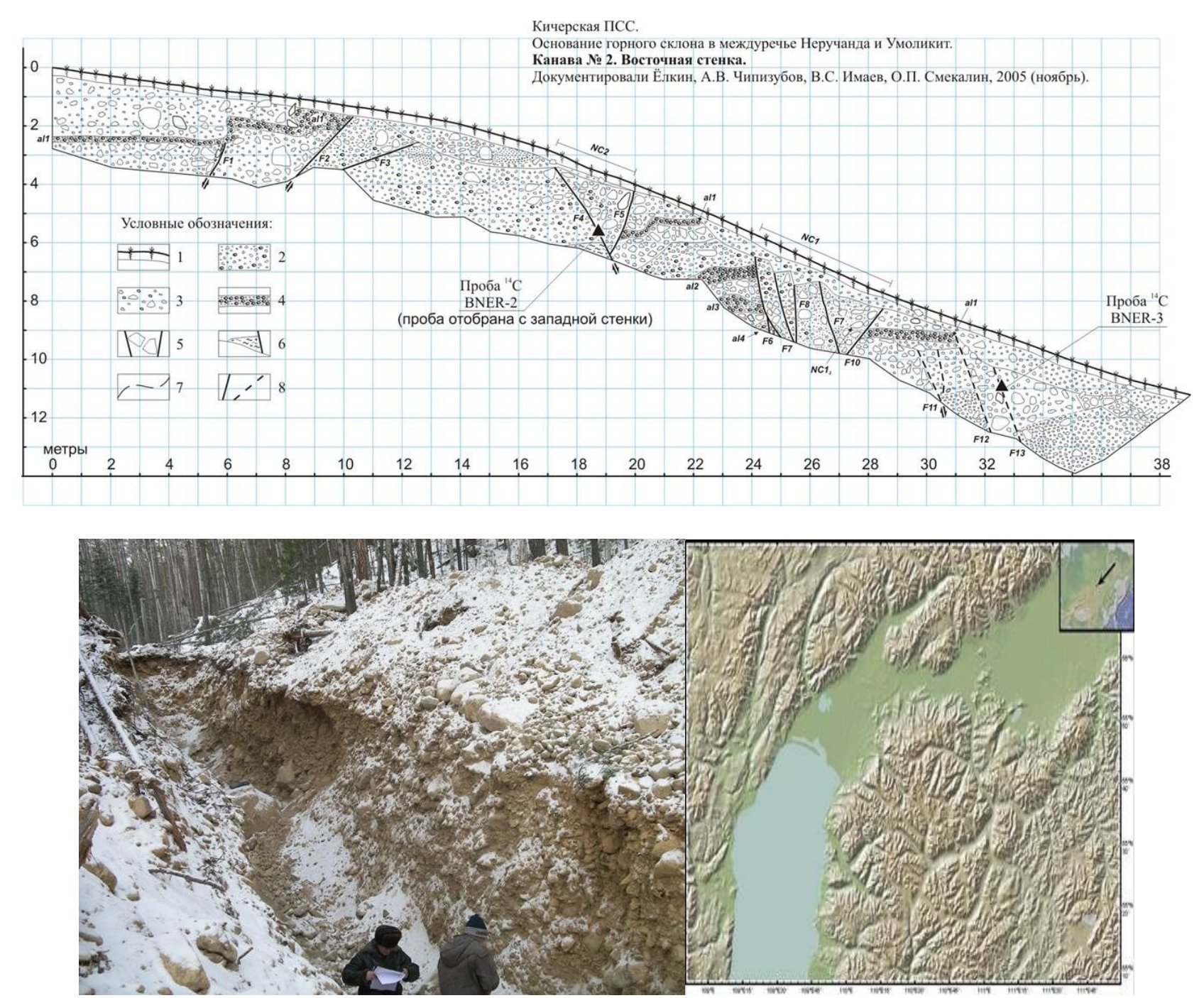

Рис. 3.4. Пример тренчинга в районе северного Байкала

\section{2. ОЦЕНКА ВОЗРАСТА ДОИНСТРУМЕНТАЛЬНЫХ ЗЕМЛЕТРЯСЕНИЙ}

Датирование землетрясений прошлого осуществляется путем определения и сопоставления возрастов природных или антропогенных объектов, испытавших сейсмическое воздействие (преддата) и возникших после него (постдата). Реже удается геологически зафиксировать момент самого сейсмического события. Такими показателями собственно землетрясений являются так называемые коллювиальные клинья (продукты обвала материала склона возникшего разломного уступа) в зонах сейсмогенных разломов и сейсмогенные разрушения археологических объектов. Определение возраста подвижки (землетрясения) включает в себя датирование коллювиального клина или разрушенного археологического объекта и наиболее древней части перекрывающих их образований.

Методы датирования доинструментальных землетрясений голоцена и конца плейстоцена разделяются на относительные и абсолютные (табл. 3.1). К первым относятся методы детальной биостратиграфии с ее разновидностями - археостратиграфической (датирование 
отложений по содержащимся в них артефактам) и палинологической (спорово-пыльцевым анализом), климатостратиграфический, палео - и археомагнитный, тефрохронологический и другие приемы геологической корреляции молодых комплексов горных пород.

Таблица 3.1

Классификация методов возрастного датирования, применяемыхв палеосейсмологии (по Дюж. МакКэлиину (Paleoseismology, 1996))

\begin{tabular}{|c|c|c|c|c|c|}
\hline \multirow[b]{2}{*}{ Типы методов } & \multirow[b]{2}{*}{ Методы } & \multicolumn{4}{|c|}{ Типы результатов } \\
\hline & & 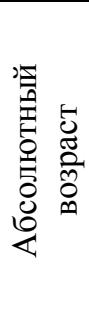 & 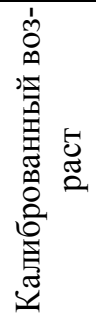 & 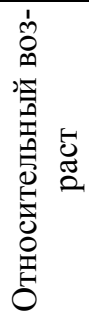 & 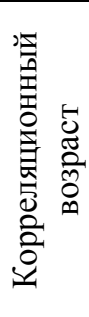 \\
\hline \multirow{3}{*}{ Календарный } & Исторические сводки & $\boldsymbol{\Delta}$ & & & \\
\hline & Дендрохронологический & $\boldsymbol{\Delta}$ & & & \\
\hline & Сезонно-слоистый & - & & & \\
\hline \multirow{4}{*}{ Изотопный } & Радиоуглеродный $\left({ }^{14} \mathrm{C}\right)$ & $\Delta$ & o & & \\
\hline & $\mathrm{K}-\mathrm{Ar}$ и ${ }^{39} \mathrm{Ar}-{ }^{40} \mathrm{Ar}$ & - & $\circ$ & & \\
\hline & Урановая серия & $\Delta$ & 0 & & \\
\hline & Космогенные изотопы ${ }^{210} \mathrm{~Pb},{ }^{36} \mathrm{Cl}$ и др. & - & o & & \\
\hline \multirow{2}{*}{ Радиоактивный } & Люминесцентный & $\Delta$ & $\Delta$ & o & \\
\hline & Электронно-резонансный & - & - & o & \\
\hline \multirow{5}{*}{ Химико-биологический } & Аминокислотный & o & - & - & o \\
\hline & Обсидиан и тефра-гидратный & 0 & - & - & $\mathrm{o}$ \\
\hline & Лихенометрический & o & $\Delta$ & $\Delta$ & o \\
\hline & Почвенно-химический & 0 & - & - & $\mathrm{o}$ \\
\hline & Химический & o & - & - & 0 \\
\hline \multirow{5}{*}{ Геоморфологический } & Развитие почвенных горизонтов & & $\mathrm{o}$ & - & - \\
\hline & Выветривание пород и минералов & & o & - & - \\
\hline & Морфометрия & & $\circ$ & $\boldsymbol{\Delta}$ & $\boldsymbol{\Delta}$ \\
\hline & Скорость осадконакопления & & 0 & - & - \\
\hline & $\begin{array}{l}\text { Соотношение геоморфологических элемен- } \\
\text { тов }\end{array}$ & & 0 & $\boldsymbol{\Delta}$ & $\boldsymbol{\Delta}$ \\
\hline \multirow{6}{*}{ Корреляционный } & Литостратиграфический & & & o & $\Delta$ \\
\hline & Тефрохронологический & & & o & $\Delta$ \\
\hline & Палеомагнитный & & & $\circ$ & - \\
\hline & Палеонтологический & & & 0 & $\Delta$ \\
\hline & Археологический & & & o & $\Delta$ \\
\hline & Стабильные изотопы & & & $\circ$ & - \\
\hline
\end{tabular}

Примечание: $\mathbf{\Delta}$ - адаптированные к датированию палеоземлетрясений в голоцене $и$ наиболее часто используемые методы, - - наиболее подходящие методы для получения соответствующего результата, о - менее подходящие методы.

Среди «абсолютных» методов наиболее эффективны радиоизотопные. Чаще других применяется радиоуглеродное датирование, временной интервал которого (максимум, до 50 тыс. лет) практически перекрывает временной интервал, необходимый для выявления активных разломов и палеоземлетрясений, значимых для параметризации современных зон ВОЗ. 
Ниже приводятся конкретные примеры обнаруженных и обследованных палеосейсмогенных структур в разных частях Восточной Сибири, приуроченные к отдельным сегментам сейсмических поясов и, как правило, трассирующие отдельные активные разломы.

\section{3. СЕЙСМОДЕФОРМАЦИИ ГОРНО-АЛТАЙСКОГО (ЧУЙСКОГО) ЗЕМЛЕТРЯСЕНИЯ 2003 ГОДА}

На юге Сибири, в пределах Горного Алтая, на территории Северо-Чуйского хребта 27 сентября 2003 г. произошло сильнейшее за всю историю сейсмологических наблюдений землетрясение с магнитудой М=7.3 и интенсивностью в эпицентре 9 баллов (Старовойт и др., 2003). С сейсмотектонической и сейсмологической позиции эпицентральная зона этого сейсмического события была детально обследована и изучена осенью 2003 года. Были выявлены и задокументированы основные типы сейсмодислокаций, связанные с выходом на поверхность сейсмического очага и сильными сотрясениями местности в результате главного толчка. Результаты исследований позволили выяснить геологическую структуру, породившую эту сейсмическую катастрофу, а также составить представление о строении сейсмического очага на глубине.

Палеосейсмогеологические работы, проведенные в предшествующий землетрясению период на территории Горного Алтая, дали возможность не только предвидеть возможность возникновения землетрясений такой силы в этой части Российской Федерации, но и установить период их повторяемости в течение последних девяти тысяч лет с магнитудой 7.0-7.5 и периодом повторяемости от 1000 до 2000 лет (Рогожин, Платонова, 2002). На основе палеосейсмологических исследований, направленных на выявление и датирование нарушений рельефа, связанных с древними сейсмическими событиями, для Чуйско-Курайской зоны Горного Алтая был оценен сейсмический режим в течение голоцена, для чего проведено совместное использование сейсмологических материалов об умеренных и слабых современных землетрясениях с одной стороны, и палеосейсмологических данных о сильнейших древних сейсмических событиях - с другой (Рогожин и др., 2004). Был построен график повторяемости землетрясений, базирующийся на имеющихся инструментальных, исторических и вновь собранных палеосейсмологических материалах. Полученные результаты свидетельствуют о прямолинейности построенного графика повторяемости землетрясений в исследованной зоне. То есть сейсмический режим Горного Алтая в голоцене оставался неизменным.

Сразу после землетрясения в эпицентральной зоне было проведено предварительное полевое обследование последствий землетрясения (Геодаков и др., 2003). Землетрясение 27 сентября 2003 г. сопровождалось образованием многочисленных нарушений земной поверх- 
ности (сейсмодислокаций). Возникли как первичные - система сейсморазрывов, так и вторичные, сейсмогравитационные и вибрационные сейсмогенные нарушения. К вторичным дислокациям относятся возникшие в результате землетрясения оползни, горные обвалы, осыпи и камнепады, сейсмогравитационные отседания склонов, выбросы разжиженного песчаноглинистого материала в виде грифонов и грязевых вулканчиков и компенсационные проседания земной поверхности. Подземные толчки привели к нарушению естественных форм рельефа в основном в горной части плейстосейстовой области землетрясения.

В ходе вспарывания земной коры очаг землетрясения вышел на поверхность в виде протяженной (около 20 км), сглаженной S-образной в плане системы первичных сейсморазрывов. Эта система разрывов ориентирована в целом в запад - северо-западном направлении, нарушает дневную поверхность на восточном погружении Северо-Чуйского хребта, не считаясь с рельефом. Сейсморазрывы выстроены в ортогонально сопряженную систему трещин сжатия и растяжения, характеризующую подвижку в очаге как практически чистый сдвиг в горизонтальной плоскости. Трещины растяжения представляют собой колоссальные зияющие рвы шириной до 0.1-10 м, длиной до 500 м и глубиной до 30 м. Структуры сжатия выражены более короткими (до 50 м) линейными валами вспучивания и сдваивания почвенного покрова высотой до 1.5 м. По отдельным трещинам произошло горизонтальое смещение, особенно четко выраженное в местах пересечения трещин с дорогами. Максимальная амплитуда горизонтального смещения по отдельным трещинам составляет 0.5 м.

При палеосейсмогеологических исследованиях, проведенных за несколько лет до Горно-Алтайского землетрясения в Чуйско-Курайской зоне (Рогожин, Платонова, 2002), в северной части Курайской впадины были обнаружены хорошо выраженные в рельефе линейные эскарпы, обрамляющие с севера и юга активную Центрально-Курайскую антиклинальную гряду запад - северо-западного простирания параллельно ориентировке ЧуйскоКурайской системе впадин. Эти эскарпы были вскрыты траншеями. В результате «тренчинга» выяснилось, что и северный, и южный эскарпы развились над активными современными разломами, вдоль которых в недавнем прошлом происходили импульсные сейсмические подвижки. То есть, оба эскарпа представляли собой выходы на поверхность очагов сильнейших землетрясений прошлого. Результаты радиоуглеродного датирования палеопочвы, захороненной в этих клиньях, проведенные сотрудниками лаборатории Института географии РАН под руководством О.А. Чичаговой, показали, что такие сейсмические события могли

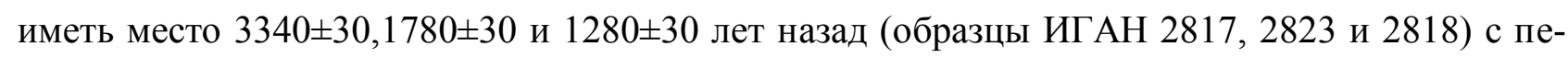
риодом повторяемости от 500 до 1500 лет.

Интересно, что при Горно-Алтайском землетрясении 2003 г. описанный эскарп вновь обновился (рис. 3.5). Вдоль подстилающего его разрыва в верхней части сглаженного склона 
за счет поднятия южного крыла возник крутой уступ высотой 30-40 см, верхняя часть которого обрушилась и образовала цепь микрооползней и небольших осыпей рыхлого материала в просевшем северном крыле. В подножье уступа наметилась извилистая зияющая трещина шириной 3-5 см. В целом обновленная дислокация зоны разлома очень напоминает первичный сейсморазрыв взбросового типа.

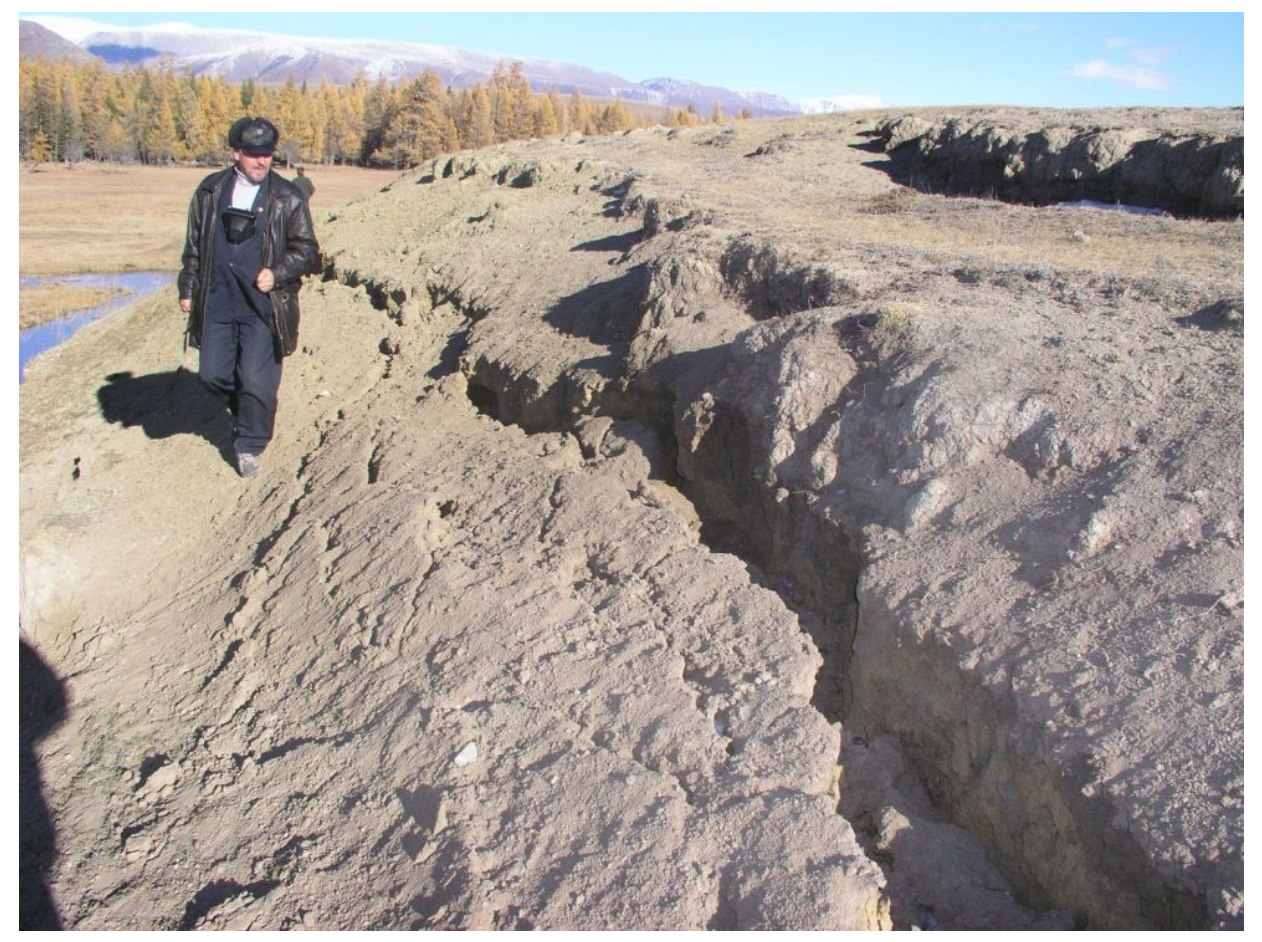

\section{Рис. 3.5. Эскарп на северном крыле Центрально-Курайской антиклинальной гряды (октябрь 2003 г.)}

Самый масштабный след землетрясения, крупный оползень на правом борту долины р. Талдура, в 7 км к западу от Бельтира, приурочен к зоне выхода очага на поверхность и пространстивенно тяготеет к области древних оползней (рис. 3.6). При этом стенка отрыва последних по времени оползневых масс точно ложится в зону распространения первичных сейсморазрывов, один из которых, по всей видимости, явился заколом на поверхности склона, инициировав сход оползня. Оползень отсел по стенке отрыва высотой около 150 м и продвинулся в долину на расстояние не меньше 100 метров. Объем оползневой массы по приблизительным подсчетам составляет около 30 млн. м³. Подобные оползни и оплывины гораздо меньших масштабов образовались на склонах долин рек Чаган и Чаган-Узун. 

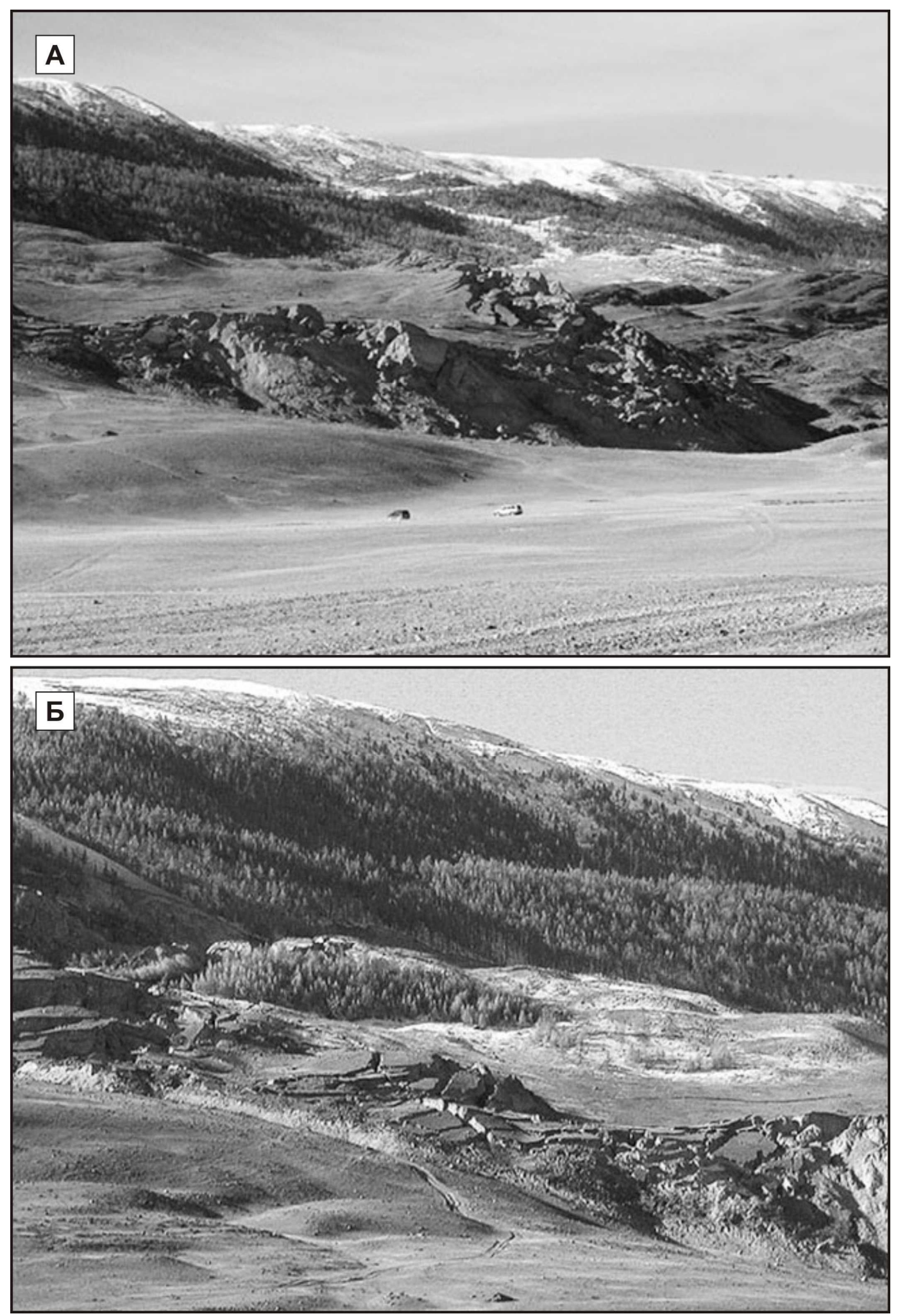

Рис. 3.6. Сейсмогенный оползень-обвал, возникиий в результате катастрофического землетрясения 27 сентября 2003 года

А - общий вид оползня, Б - сейсмогенные трещины, нарушающие тело оползня. Видно фронтальное нагромождение отдельных гльюб

Широкая область охвачена обвалами скальных пород. Приурочены они в основном к отвесным скальным выступам, при этом отдельные скатившиеся глыбы достигают размеров одноэтажного дома. Сотрясения проявились также в нарушениях целостности задернованно- 
го рыхлого чехла на склонах в привершинной части положительных форм рельефа и в частичном его перемещении с образованием характерного надвигания дерна в нижних частях склонов (рис. 3.7, 3.8).
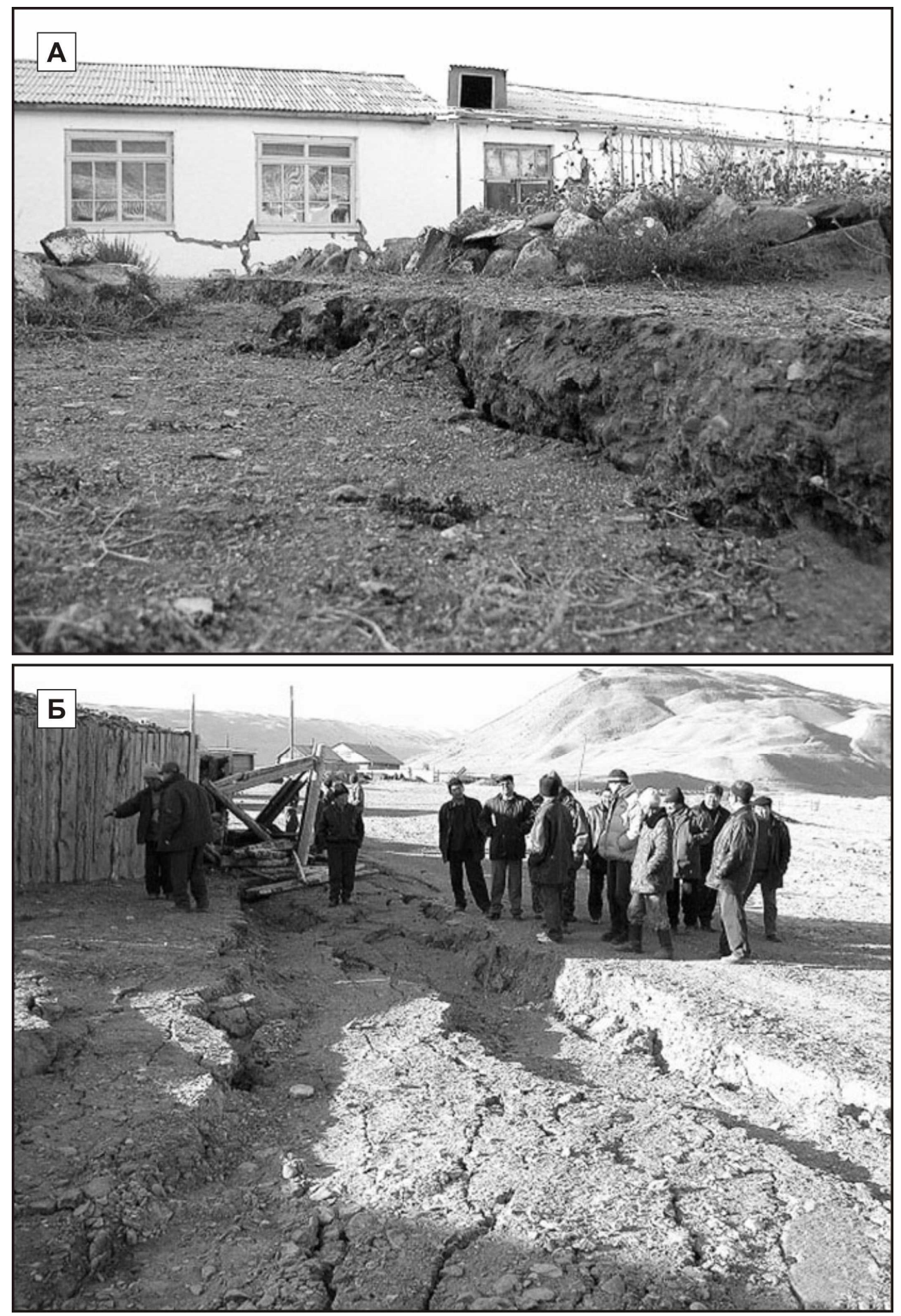

Рис. 3.7. Сейсмогенные трещины деформирующие постройки с. Бельтир

$A$ - взброс с амплитудой вертикального перемещзения в 60-80 cм, пересекающий здание больницы, $B$ - трещины, по которым произошло просаживание грунта и смещение отдельных построек 


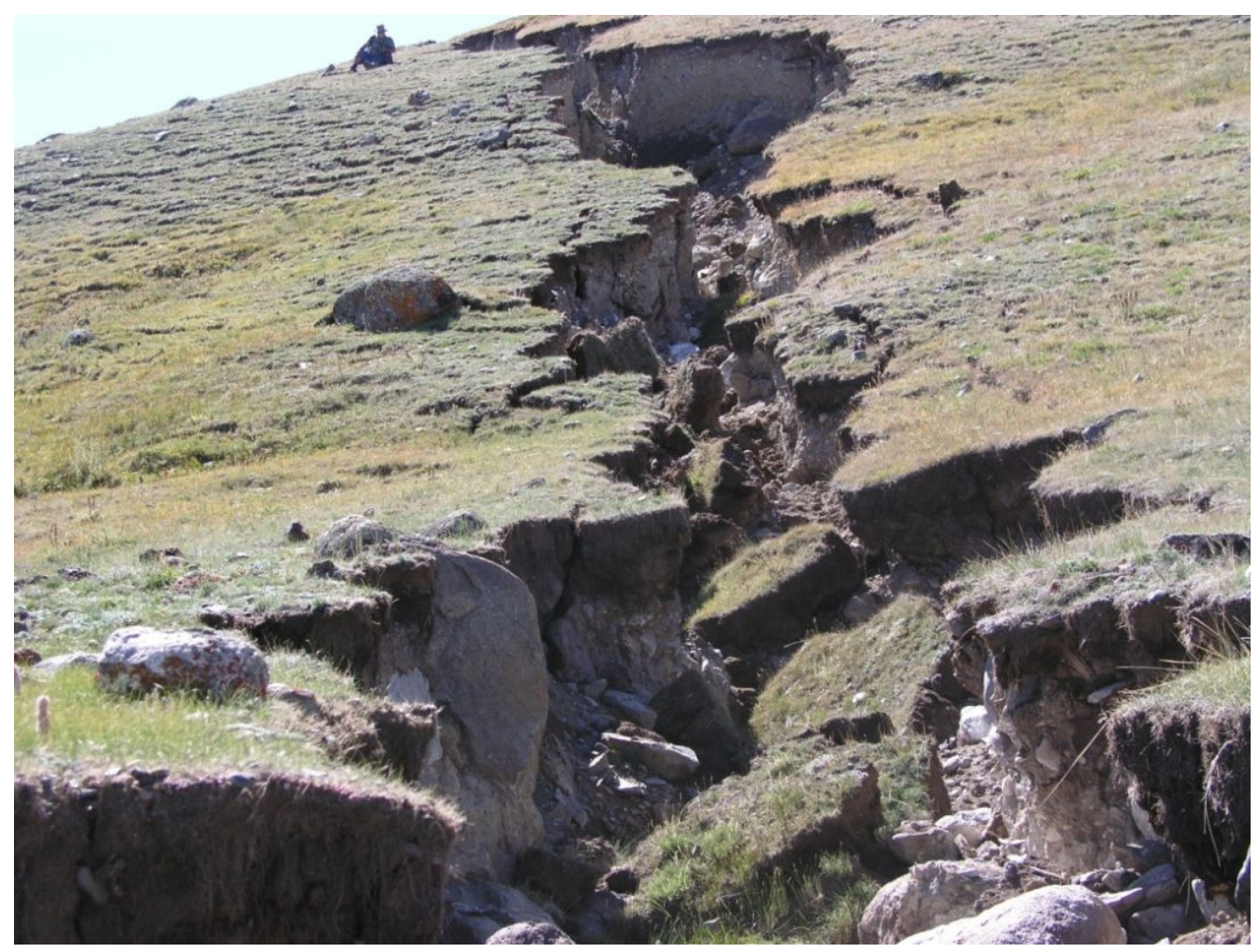

Рис. 3.8. Современные трещины-отрывы, возникиие в результате Горно-Алтайского землетрясения 2003 года

Примечательно, что склоны водоразделов крупных водотоков плейстосейстовой области разбиты разломами - сколами, рассекающими коренные породы и по которым отчетливо читаются сдвиговые смещения. Несомнено, что такие разломы не потеряли своего сейсмического потенциала, хотя связаны, скорее всего, с палеоземлетрясениями недалекого прошлого (рис. 3.9).

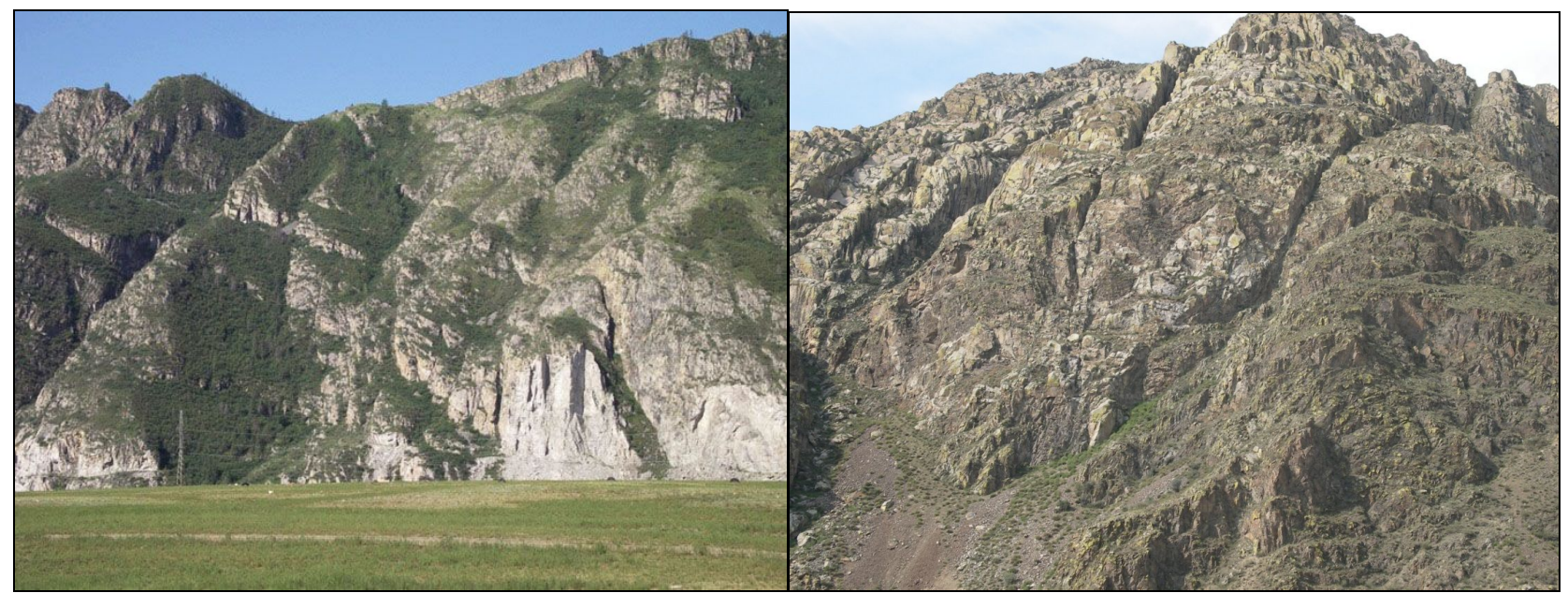

Рис. 3.9. Сдвиговые сейсмогенные разломы, рассекающие карбонатные толщии Горного Алтая 


\section{4. ПАЛЕОСЕЙСМОДИСЛОКАЦИИ ЗАПАДНОГО САЯНА}

В пределах сейсмоопасной зоны Тувы находится несколько палеосейсмотектонических дислокаций. Это палеосейсмодислокации Ат-Чол-Дуг, Узун-Хем, Кодура-Холь. Имеется и серия сейсмогравитационных обвалов под общим названием Кара-Холь. Параметры сейсмотектонических палеосейсмодислокаций (ПСД) приведены в таблице 3.2. Наиболее важные и близкие к комбинату будут описаны по первоисточникам ниже.

\section{Палеосейсмотектонические дислокации}

Таблица 3.2

(Вдовин, Зеленков, 1982, Аржанников, Зеленков, 1995)

\begin{tabular}{|c|c|c|c|c|c|c|c|c|c|}
\hline \multirow[t]{2}{*}{$\mathrm{N}$} & \multirow{2}{*}{$\begin{array}{c}\text { Название } \\
\text { ПСД }\end{array}$} & \multicolumn{2}{|c|}{$\begin{array}{c}\text { Координаты } \\
\text { центра }\end{array}$} & \multicolumn{3}{|c|}{ Параметры ПСД } & \multirow{2}{*}{$\begin{array}{l}\text { Тип сме- } \\
\text { щения }\end{array}$} & \multirow{2}{*}{$\begin{array}{l}\text { Магни- } \\
\text { туда }\end{array}$} & \multirow{2}{*}{$\begin{array}{c}\text { Источ- } \\
\text { ники }\end{array}$} \\
\hline & & $\varphi$ & $\lambda$ & $\mathrm{L}$ & $\mathrm{D}$ & $\mathrm{H}$ & & & \\
\hline 1 & 2 & 3 & 4 & 5 & 6 & 7 & 8 & 9 & 10 \\
\hline 12 & Узун-Хем & 52.28 & 94.96 & 3.2 & - & 3 & Взброс & 7.0 & 3 \\
\hline 14 & Ат-Чол-Дуг & 52.16 & 95.58 & 4 & $?$ & 2.5 & Л. сд.-в. & 7.0 & $1,2,3$ \\
\hline 15 & Кодура-Холь & 52.29 & 96.42 & 24 & $?$ & 3 & Л. сд. & $6.9 / 7.4$ & 4 \\
\hline 16 & Кара-Джарик & 51.37 & 96.19 & 1 & - & 4 & Взброс & 7.0 & 3 \\
\hline
\end{tabular}

Примечание: L - длина сейсмодислокаций; D - горизонтальное смещение; $H$ - вертикальное смещение; М -магнитуда землетрясения. Порядковый номер сейсмоструктуры соответствует номеру внемасштабного знака на схеме активных разломов.

Источники: 1 - Вдовин, Зеленков, 1982; 2, 4 - Аржанников, Зеленков, 1995; 3 - Аржанников, 1998.

ПСД Ат-Чол-Дуг впервые описана в работе В.В. Вдовина и П.Я. Зеленкова (1982). Структура расположена в среднем течении р. Ат-Чол-Дуг - правый приток р. Улуг-О. Она представлена разрывом, смещающим ледниковые отложения, и выражена в рельефе уступом северо-западного простирания высотой 1.5-2.5 м на протяжении 4 км (рис. 3.10). Дополнительные исследования, проведенные С.Г. Аржанниковым (2000), показали, что по элементам внутренней структуры (кулисообразное размещение разрывов, выраженных уступами) подвижка является, скорее всего, сдвиго-взбросом. Максимальная амплитуда взброса оценивается в 4.5 м, а сдвиговая составляющая количественно не определена ввиду отсутствия явных реперов. Судя по морфологической выраженности и степени сохранности различных фрагментов палеосейсмодислокации (Вдовин, Зеленков, 1982), ее формирование происходило в два этапа. Западный фрагмент (длина 2 км, смещение 2 м) отвечает более раннему сейсмическому событию, а восточный фрагмент (длина 4 км, смещение 2.5 м) сформировался при более позднем палеособытии (Аржанников, 2000). Исходя из этих параметров, наиболее реальная магнитуда первого палеособытия должна находиться в пределах 6.7-6.8, а второго $-6.8-7.0$. 


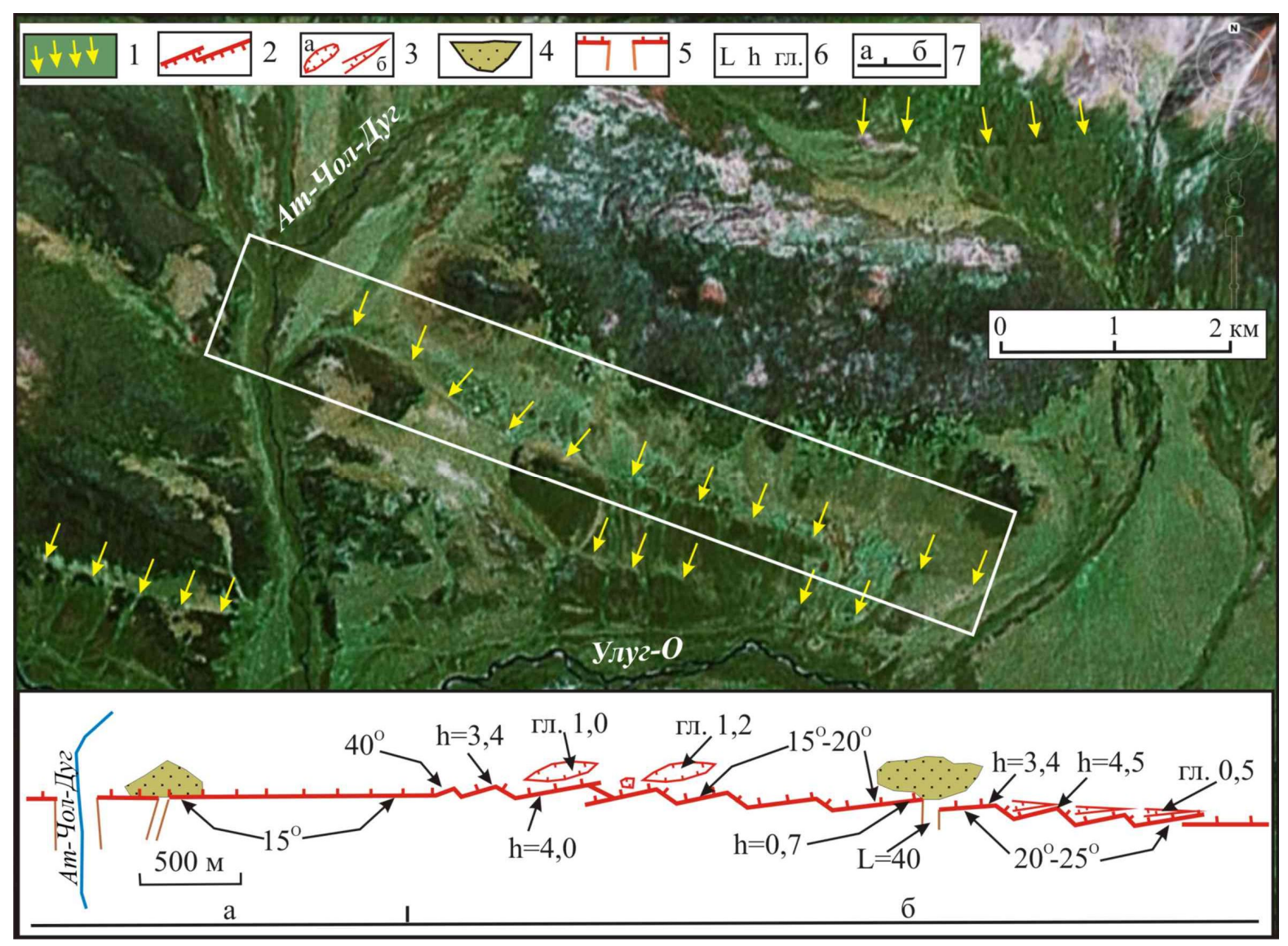

Pис. 3.10. Схема ПСД Ат-Чол-Дуг на дистанционном снимке "Google»

Ситуачия на врезке по данным С.Г. Аржанникова (2000): 1 - трассировка палеосейсмодислокаций; 2 - сейсмотектонические уступь; 3 - грабенообразные и клиновидные присдвиговые опускания; 4 - спущенные озера;5 - долины прорыва в сейсмотектоническом уступе; 6 параметры ПСД (гл. - глубина опускания в $м, h$ - выссота уступа в $M, L$ - иирина долин прорыва в м); 7 - древние (а) и молодые (б) ПСД

ПСД Кодура-Холь расположена на правом борту долины р. Бол. Енисей в 30 км юговосточнее пос. Тоора-Хем (рис. 3.11, 3.12). Ее длина составляет 24 км. Сейсмогенные деформации в рельефе представлены трещинами растяжения, валами сжатия, уступами, сейсмогравитационными отесданиями и оползнями. Разрывы деформируют высокую пойму, комплекс террас, склоны и междуречья. Простирание структуры меняется с 85-90 на западном фланге до $45^{\circ}$ в центральной части и вновь до $85-90^{\circ}$ на восточном окончании. Крупномасштабные деформации в виде кулисообразных микрограбенов протяженностью до 250 м, шириной до 40 м, и более протяженных долинообразных понижений глубиной до 8, а также сейсмогенных уступов высотой до 4-7 м более или менее отчетливо видны даже на объемной модели рельефа. В плане основные разрывы имеют S-образную форму, что и определяет разнообразие типов нарушений, составляющих внутреннюю структуру палеосейсмогенной дислокации. Если на флангах, имеющих широтную ориентировку, проявились сдвиги, то в центральной части, северо-восточного простирания, преобладающими были сбросы. В целом 
структура характеризуется как левосторонний сдвиг. Исходя параметров ПСД Кодура-Холь $(\mathrm{L}=24, \mathrm{D}=3)$, наиболее реальная магнитуда должна находится в пределах $7.3(\mathrm{MD})-6.8(\mathrm{ML})$ или $7.4(\mathrm{MD})-6.9(\mathrm{ML})$.

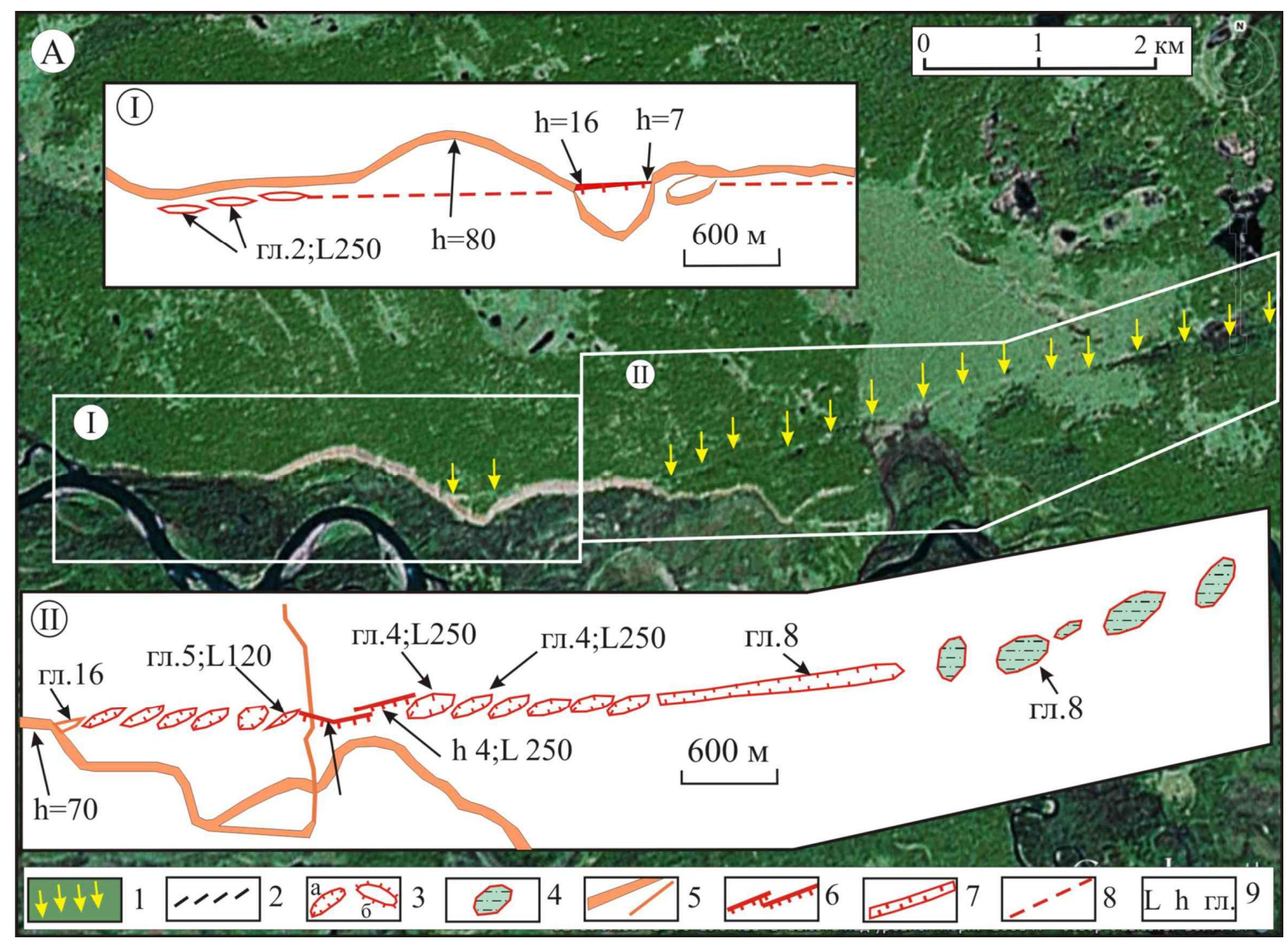

Pис. 3.11. Фрагменты I и II ПСД Кодура-Холь на дистанционном снимке "Google» Ситуачия на врезках по данным С.Г. Аржанникова (2000): 1 - трасса ПСД; 2 - разрывные кулисы; 3 - кулисообразные микрограбены (а) и валообразные поднятия (б); 4 - впадины, иногда заполненные водой; 5 -террасовые уступь; 6 - сейсмотектонические уступы; 7 долинообразные понижения; 8 - предполагаемые сейсмодеформации; 9 - параметры элементов ПСД (гл. - глубина опускания в м, $h$ - высота уступа в.,$L-$ длина в м)

Каа-Хемский разлом, начинаясь в правобережье р. Енисей в верховьях р. Беделиг, прослеживается в северо-восточном и близширотном направлениях, где по его зоне фиксируется левостороннее смещение верховий рек Беделиг, Орта-Хем, Уйлуг-Хем, Эйлиг-Хем и ДемирСуг с амплитудой до 3.5 км. Далее по простиранию он контролирует развитие южного борта Турано-Уюкской впадины, проходит в верховьях правых притоков рек Тапса, Дерзиг, где по данным Ю.В. Чудинова (1959) зона разлома состоит из сближенных параллельных субширотных разрывов и по их зонам наблюдается левостороннее смещение с амплитудой 1-2 км. Суммарная амплитуда сдвига в этом районе достигает 10 км (Чудинов, 1959). Затем, просле- 
живаясь по южному фасу хр. Донгул-Тайга, разлом в виде дуги уходит на юго-восток в район бассейна р. Ужеп и распадается на серию сближенных субмеридиональных нарушений, где контролирует горстовую структуру хр. Ыдык. Южнее разлом выражен тектонической долиной р. Улуг-Шивей.

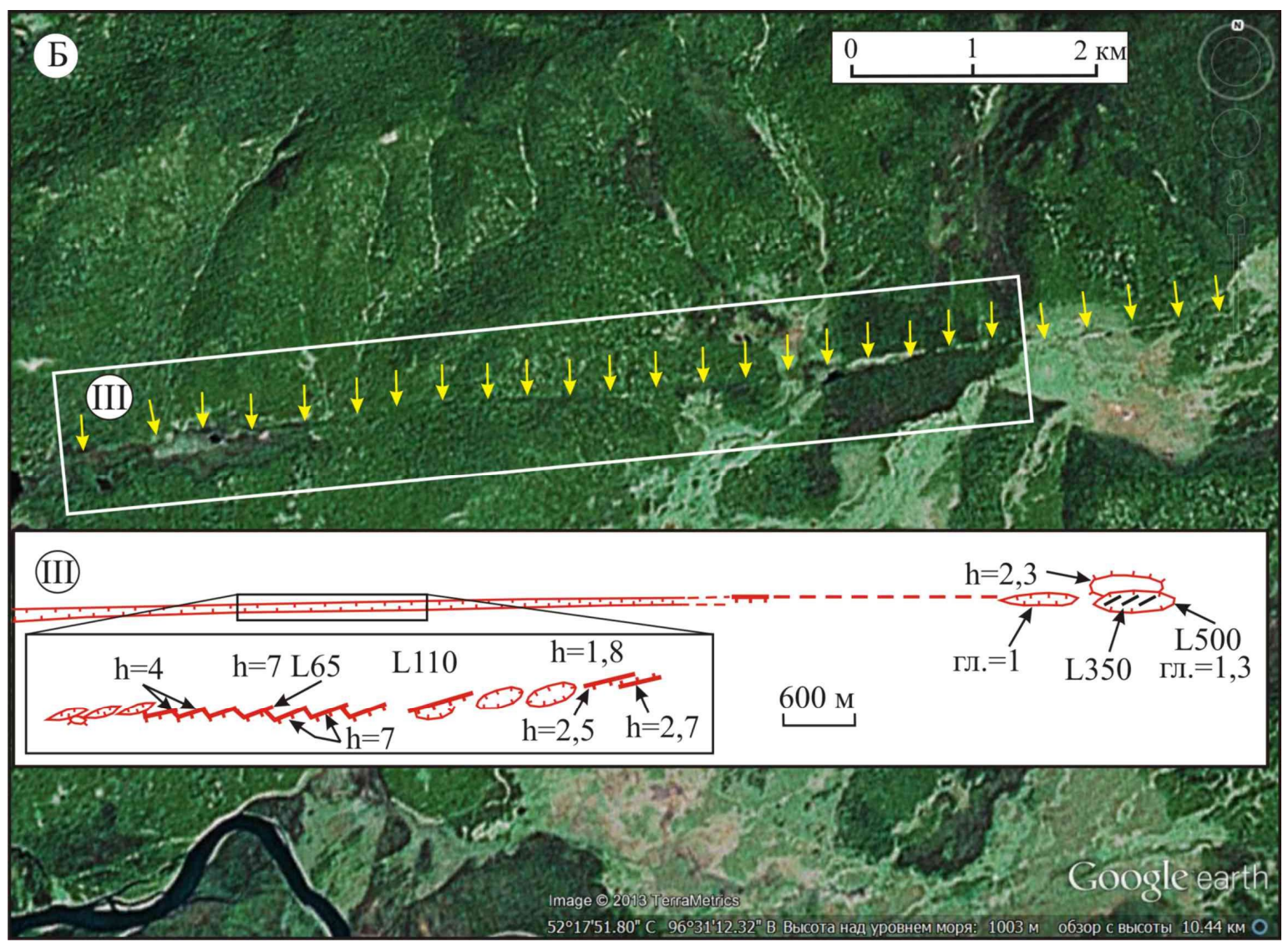

\section{Pис. 3.12. Фрагмент ІІІ ПСД Кодура-Холь на дистанционном снимке "Gооgle». Ситуация на врезке по данным С.Г. Аржанникова (2000)}

По данным аэровизуальных наблюдений и дешифрирования ДДЗ можно полагать, что для сегментов Каахемского разлома с субмеридиональной ориентировкой свойственна преимущественно правосдвиговая кинематика смещения; для субширотных сегментов - взбросовая. Сдвиговые смещения молодых форм рельефа в долине р. Шуй выражены ярко и свидетельствуют о неоднократных сейсмогенных подвижках (рис. 3.13).

Горизонтальное смещение молодых форм рельефа - распадков и водоразделов на западном склоне северной части хр. Ыдык и на западных склонах хр. Час-Тайга - позволяет оценить суммарную амплитуду молодых (познеплейстоцен-голоценовых) правосдвиговых движений в 150-200 м. При этом нет признаков значительных вертикальных подвижек. 


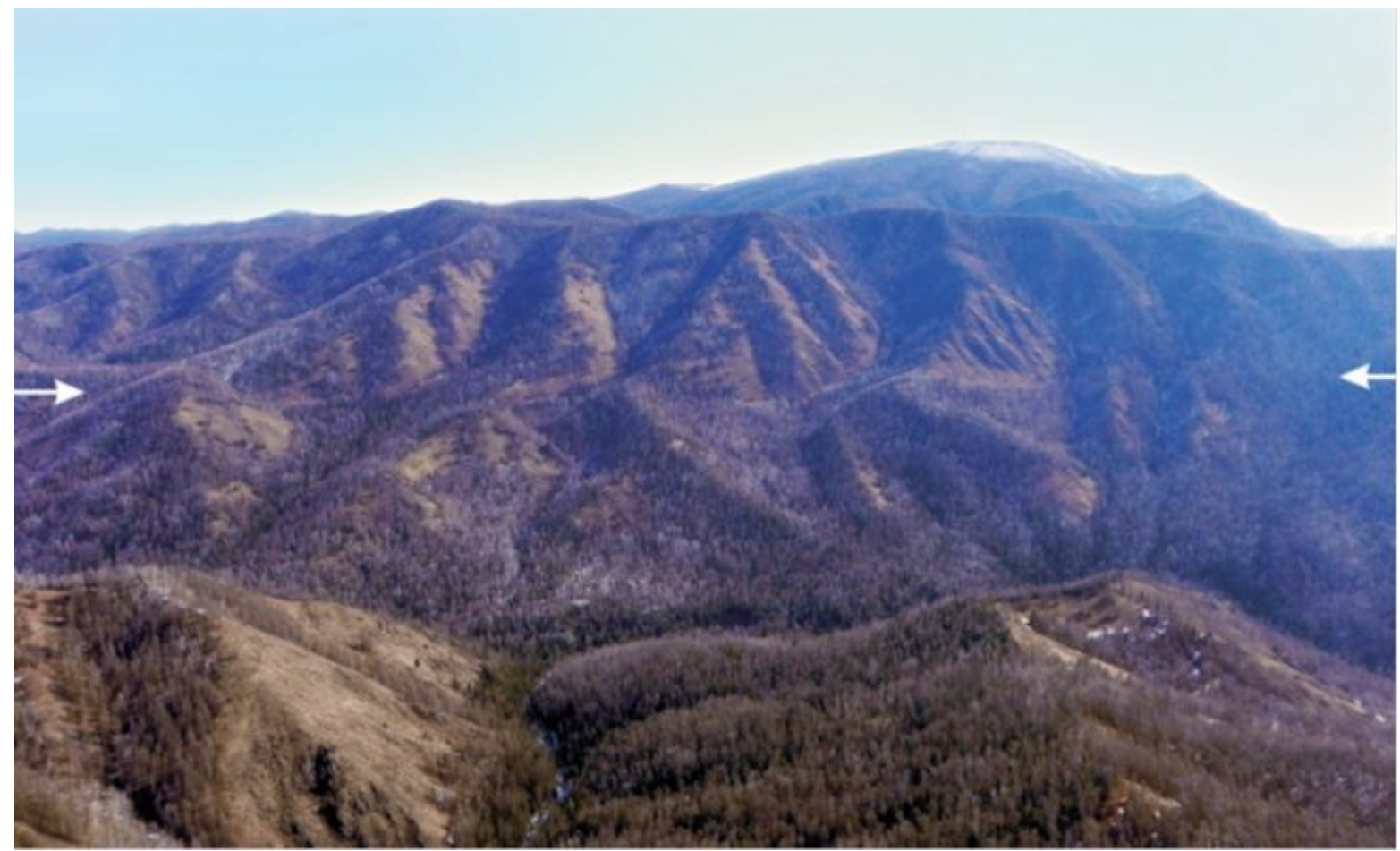

Рис. 3.13. Правый сдвиг в правом борту р. Шуй (по (Рогожин и др., 2012))

В пользу взбросовой кинематики смещений на близширотно ориентированном сегменте зоны разломов Каа-Хем может свидетельствовать плановая конфигурация молодых уступов на западном отрезке хр. Академика Обручева. Это хорошо видно на примере уступа в левом борту р. Биче-Оо (рис. 3.14), который отделяет поднятие хр. Академика Обручева от наклонной предгорной равнины, четко описывая контуры подножий. На пересечении с речными долинами уступ вдается вглубь хребта, отступая в противоположную сторону на водоразделах.

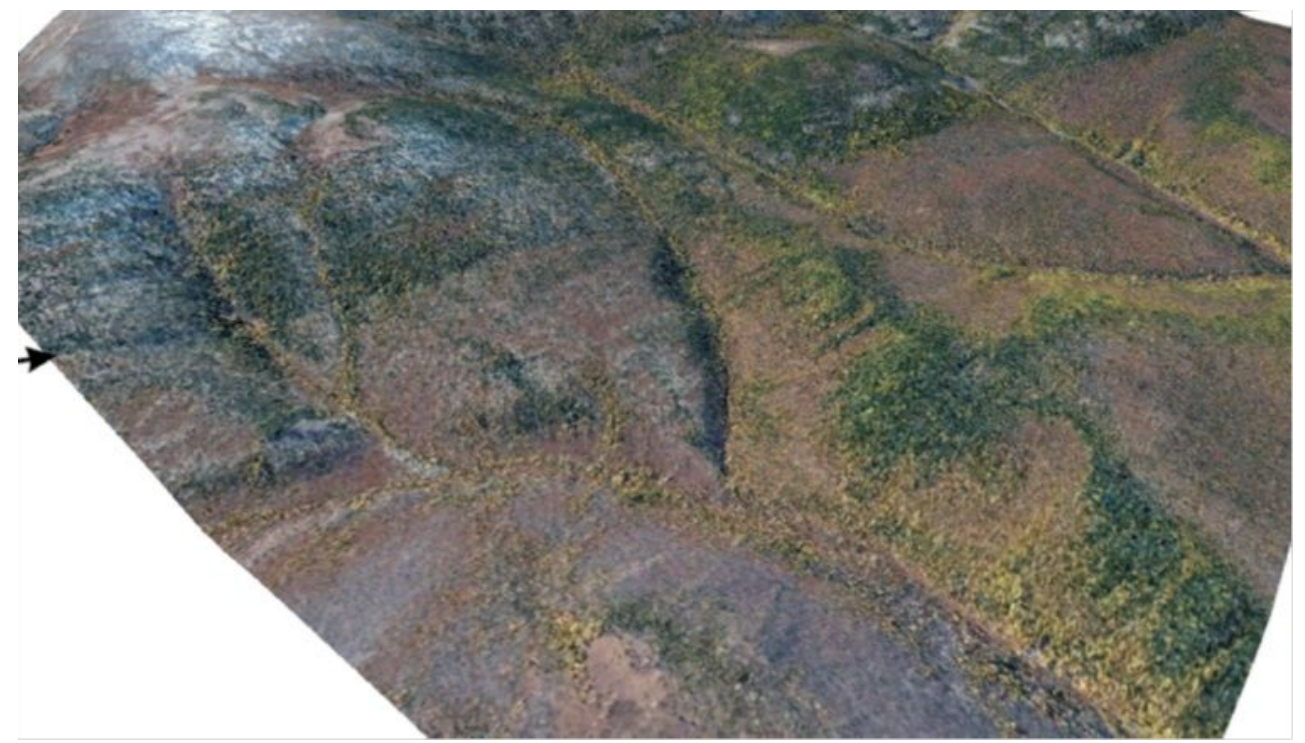

Рис. 3.14. Предположительно взбросовый молодой тектонический уступ (указан стрелками) в левом борту р. Биче-Оо (по (Рогожин и др., 2012)) 
Таким образом, проявления долгосрочных молодых смещений по близмеридиональному и близширотному сегментам зоны разлома Каа-Хем, во-первых, позволяют квалифицировать этот дизъюнктив как активный на современном этапе, а во-вторых, предположить, что очаги землетрясений 2011 и 2012 гг. были связаны именно с этими отрезками разлома.

\section{5. ПАЛЕОСЕЙСМОДИСЛОКАЦИИ ПРИБАЙКАЛЬЯ}

Основная роль в формировании структурного каркаса Байкальской рифтовой зоны принадлежит глубинным разломам, по которым в условиях преобладающего субгоризонтального растяжения, ориентированного по линии северо-запад - юго-восток, развиваются системы сбросовых нарушений (Мишарина, 1967). Наиболее активно этот процесс идет в бортах впадин Байкальской котловины, ориентированной на северо-восток, т.е. ортогонально к вектору растяжения. В качестве яркого примера развития разломов такой конфигурации и кинематики является Среднекедровская палеосейсмодислокация, прослеженная на западном борту оз. Байкал, в привершинной части Байкальского хребта, где возникший в результате палеоземлетрясения разлом рассекает склоновые отложения с хорошо видимой левосдвиговой компонентой движения (рис. 3.15). В центральной своей части разлом расщепляется на два параллельных друг другу отрезка отстоящих на расстоянии в 6-8 метров. Сама плоскость разломов подчеркнута сорванными склоновыми отложениями и отчетливым уступом, при котором нижнее висячее крыло опущено в направлении к водной поверхности оз. Байкал.

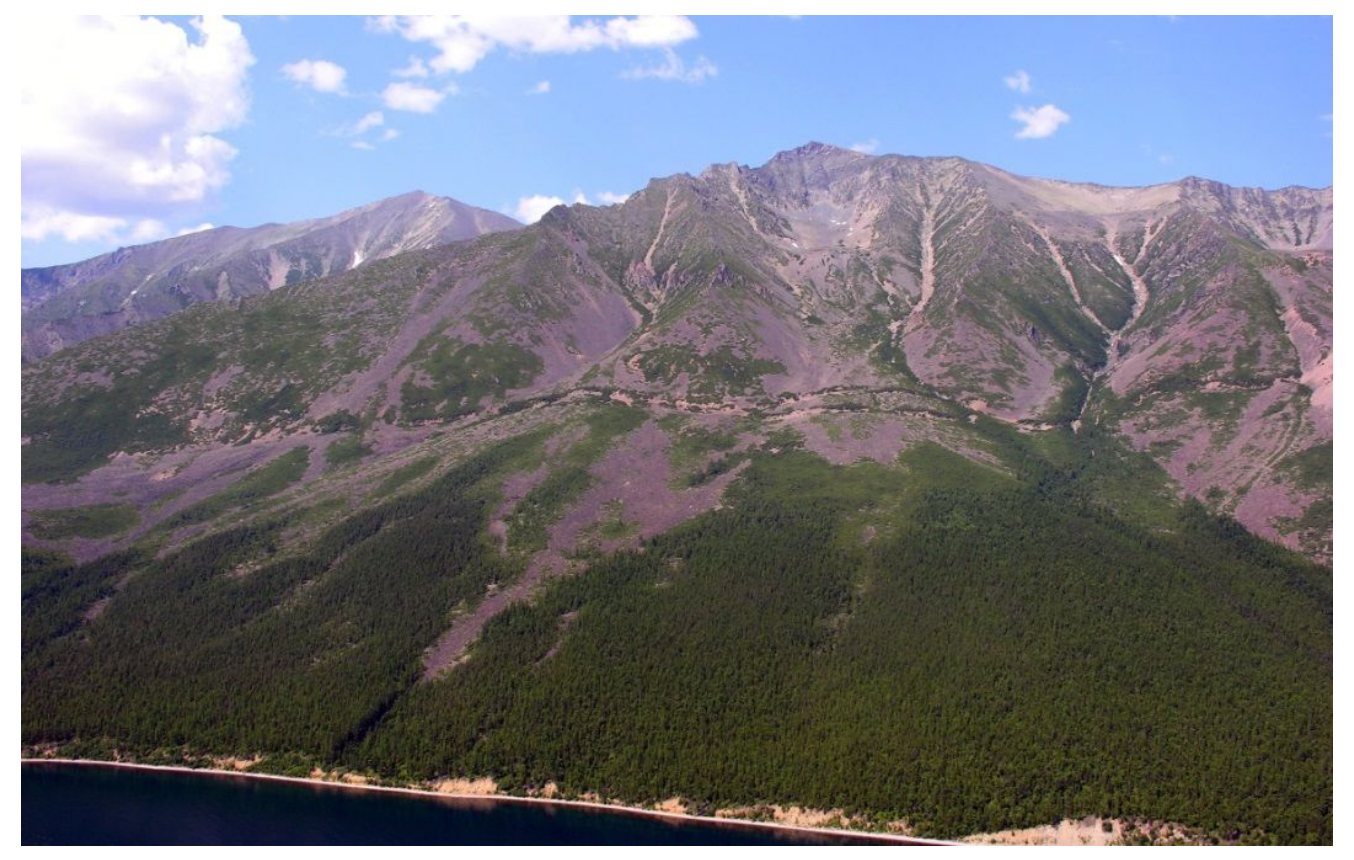

\section{Рис. 3.15. Фрагмент Среднекедровской палеосейсмодислокации, отчетливо выраженный в рельефе Байкальского хребта}

Установлено, что для широтно ориентированных разрывов фланговых отрезков БРЗ характерно сочетание сбросовых и сдвиговых перемещений. Юго-западный, наиболее изу- 
ченный в палеосейсмологическом отношении, фланг БРЗ представлен цепочкой разновеликих впадин, северные борта которых контролируются зоной Тункинского сброса, а южные Байкало-Мондинским разломом. Между собой впадины разделены неотектоническими блоками с кристаллическими перемычками, рост которых значительно отстает по скорости от роста самого Тункинского поднятия. К зоне Тункинского разлома приурочены Торская и Тункинская палеосейсмогенные структуры, протягивающиеся вдоль северных границ одноименных впадин (рис. 3.16).

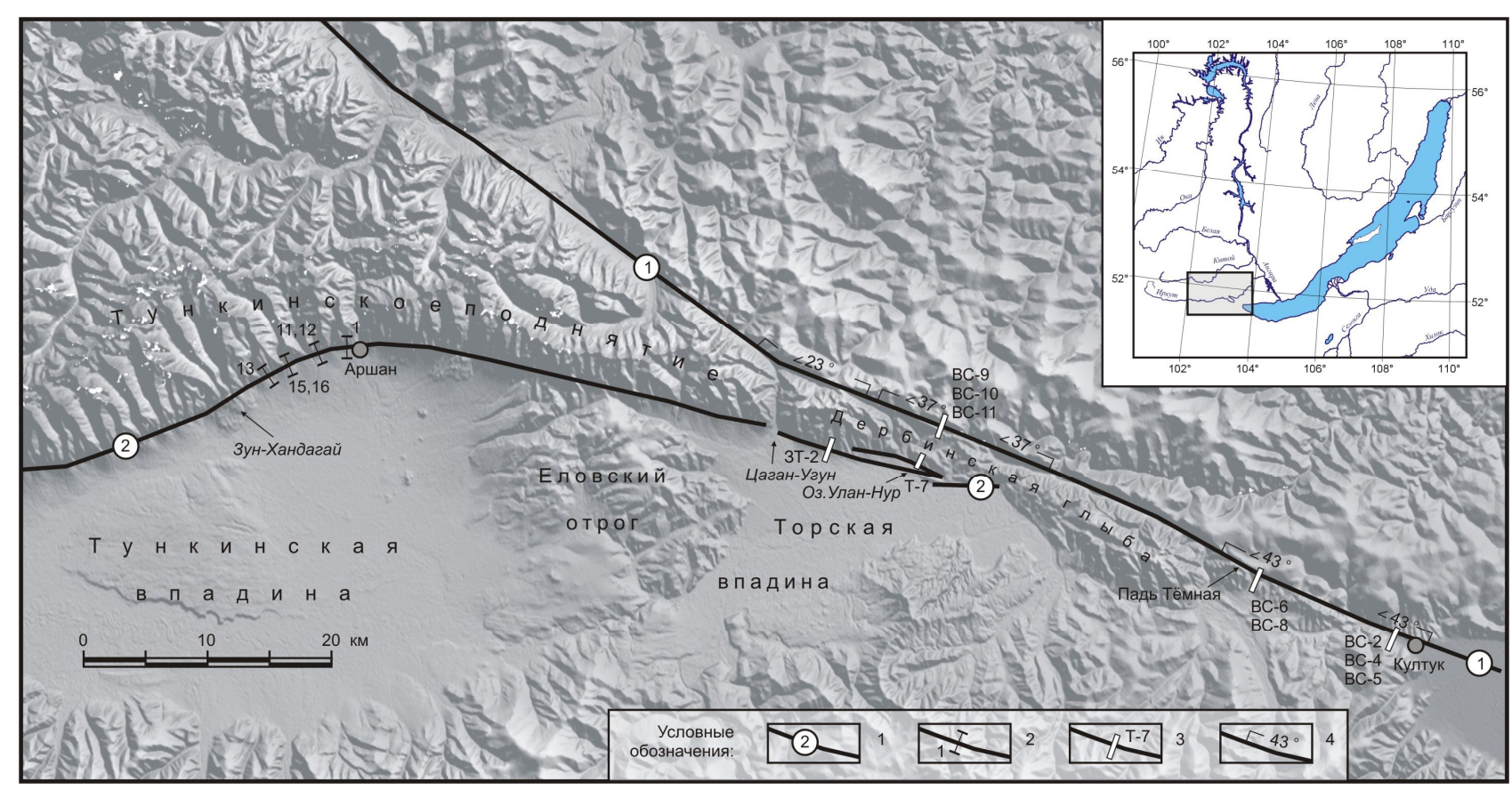

\section{Рис. 3.16. Схема объектов палеосейсмологических исследований в Юго-Западном При-} байкалье, упоминающихся в настоящей работе (Смекалин и др., 2007)

1 - зоны активных Главного Саянского (1) и Тункинского (2) разломов; 2 - профили через сейсмогенные уступы и их номера; 3 - участки тренчинга с указанием номеров канав; 4 сегментация зоны Главного Саянского Разлома по максимальным углам наклона поверхности уступа по результатам морфометрических исследований

Сейсмогенное вскрытие Тункинского разлома с перерывами охватывает весь отрезок разлома от северо-восточного окончания Торской впадины до хандагайского конуса выноса (12 км западнее пос. Аршан). Морфометрическими и тренчинговыми исследованиями дислокаций установлены разновозрастность вскрытия и различие в механизмах реализации палеоземлетрясений на торском и аршанском участках разлома, связанные со структурногеологическими особенностями строения бортов впадин и зоны сочленения Еловской кристаллической перемычки с Тункинским блоковым поднятием.

В палеосейсмологическом отношении юго-западный фланг представляет собой исключительное явление для всей Байкальской рифтовой зоны. Здесь на относительно небольшой площади в зонах двух региональных структурных элементов - Тункинского и Главного Са- 
янского разломов - проявились сейсмогенные подвижки разных кинематических типов сбросового, сбросо-сдвигового, взбросового и взбросо-сдвигового, причем ширина разделяющей сбросы по Тункинскому и взбросы и сдвиги по Главному Саянскому разлому Дербинской гранитной глыбы в районе Торской впадины не превышает пяти километров. Разнообразие генетических типов сейсмодеформаций может свидетельствовать о несколько ином, чем в самой Байкальской впадине, поле тектонических напряжений, возможно о случае переходного состояния, когда оси растяжения и сжатия близки к горизонтальной плоскости.

Более простыми, с точки зрения преобразования рельефа, представляются деформации, связанные с палеоземлетрясениями Восточно-Саянской структуры в зоне Главного Саянского разлома. В результате трех разрывообразующих землетрясений, произошедших за последние 8 тысяч лет, были вновь сформированы или обновлены дислокации на отрезке разлома протяженностью около 60 км от пос. Култук (юго-западное окончание байкальской котловины) до верховьев р. Цаган-Угунь (к северу от западной оконечности Торской впадины). Дислокации лежат в пределах широкой (до 800 м и более) зоны древнего позднеархейского заложения структурного шва, выполненного ультрамилонитами, филлонитами, и маркируют практически прямолинейный выход сместителя на поверхность, часто осложненного оперяющими разрывами с закономерным проявлением левосторонней сдвиговой структуры.

В зависимости от морфологии деформируемого рельефа дислокации представлены различными типами. Наиболее часто встречающийся случай - деформация склонов югозападной экспозиции. Здесь следы палеоземлетрясений выражены в виде обратных уступов (обращены в сторону склона), имеющих высоту до нескольких метров (рис. 3.17). О возрасте обновления уступов можно судить по их крутизне. Согласно общепринятым представлениям, основанным на эмпирических и теоретических разработках, при одинаковых высоте, геологических, климатических и прочих условиях тот уступ моложе, чья поверхность круче, тоесть, выделение разновозрастных сейсмогенных подвижек возможно по изменению углов наклона или перегибам сейсмогенных уступов.

На основании морфометрических и тренчинговых исследований установлено, что возраст деформаций Восточно-Саянской палеосейсмогенной структуры (ПСС) дважды изменяется в сторону увеличения при прослеживании их с востока на запад. Так, если в канавах в районе пос. Култук и пади Темная вскрытые деформации свидетельствуют об их неоднократном обновлении в голоцене, в том числе и в результате последнего события (около 5001000 лет назад), то в канавах, расположенных западнее, деформации, связанные с этим палеособытием, отсутствуют. Наличие нескольких эпицентральных областей в пределах единой Восточно-Саянской ПСС подтверждается и разделением всех уступов на три группы по такому параметру, как крутизна их поверхности. Наиболее крутые уступы $\left(40-43^{\circ}\right)$, генети- 
чески связанные с последним обновлением структуры, прослеживаются в пределах ее восточного фланга. Далее в западном направлении угол уклона уступов сменяется на $30-37^{\circ}$ и на $12-23^{\circ}$ на западном фланге. Более редким для Восточно-Саянской структуры является положение разрыва, когда он проходит по склону с северо-восточной экспозицией. В подобных случаях деформации выражены в виде спрямленных полосовидных фрагментов склонов повышенной крутизны (до 50). Другим основным типом деформаций по зоне Главного Саянского разлома является закономерное, последовательное расположение сопряженных между собой рвов растяжения и валов сжатия с характерной для левостороннего сдвига структурой. Такие деформации, как правило, прослеживаются на участках структуры, занимающих широкие плоские водоразделы или аккумуляционные формы, достигающие в поперечнике сотни метров.

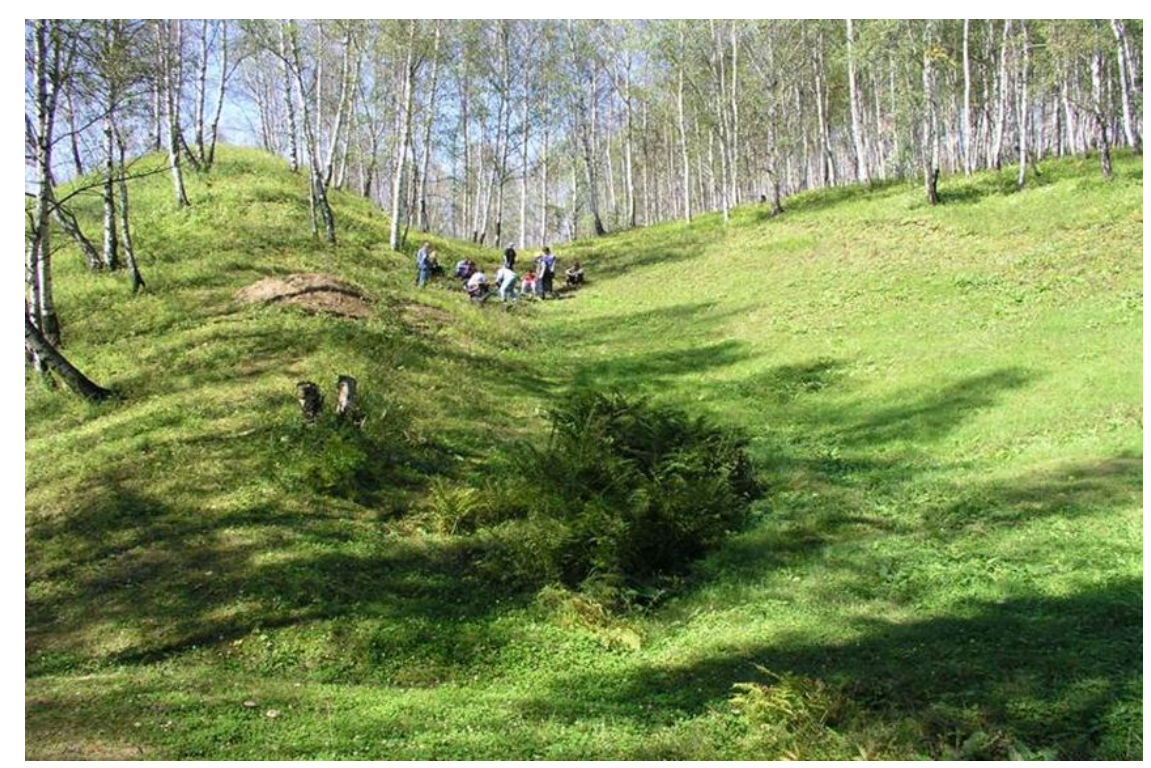

\section{Рис. 3.17. Обратный уступ (взброшено подгорное крыло) в зоне Култукской ПСД}

Амплитуды горизонтальной деформации тех или иных форм рельефа определяются двумя параметрами: количеством подвижек и амплитудами при каждой из них. Первый из этих параметров тесно связан с возрастом самого деформируемого элемента рельефа, т.е. амплитуда горизонтальной деформации является функцией от возраста деформируемого элемента и скорости движения по разлому. Необходимо также учитывать вклад различных эрозионных процессов в изменение облика деформированных элементов рельефа. Совокупностью этих факторов определяется чередование вдоль простирания структуры максимальных и минимальных амплитуд сдвига. Комплексное использование морфометрических и тренчинговых (данных полученных при проходке канавы вкрест сейсмогенного разлома) данных об абсолютных и относительных возрастах деформаций позволило установить, что амплитуда левостороннего сдвига при последнем палеособытии составила 4.7 м (величина 
смещения молодой эрозионной ложбины на окраине пос. Култук). В районе пади Темная более древняя (позднеплейстоценовая) долина шириной около 60-65 метров смещена на 60 метров (Чипизубов, Смекалин, 1999).

К настоящему времени в Прибайкалье установлено более 40 палеоземлетрясений с $\mathrm{M=7.1-8,} \mathrm{из} \mathrm{которых} \mathrm{только} 24$ датировано по ${ }^{14} \mathrm{C}$. В таблице 3.3 приведен список датированных на настоящее время палеоземлетрясений Прибайкалья. Такие палеособытия выделены в зонах Окино-Жомболокского, Баргузинского, Главного Саянского, Тункинского, Парамского, Приморского, Северобайкальского, Уколкитского и Хамбинского разломов (рис. 3.18). На рисунке вынесено местоположение всех палеосейсмодислокаций под номерами соответствующих таблице 3.3, причем размеры установленных палеоочагов показаны в виде расчетных эллипсов, длинные оси которых совпадают с величиной разрыва в очагах землетрясений.

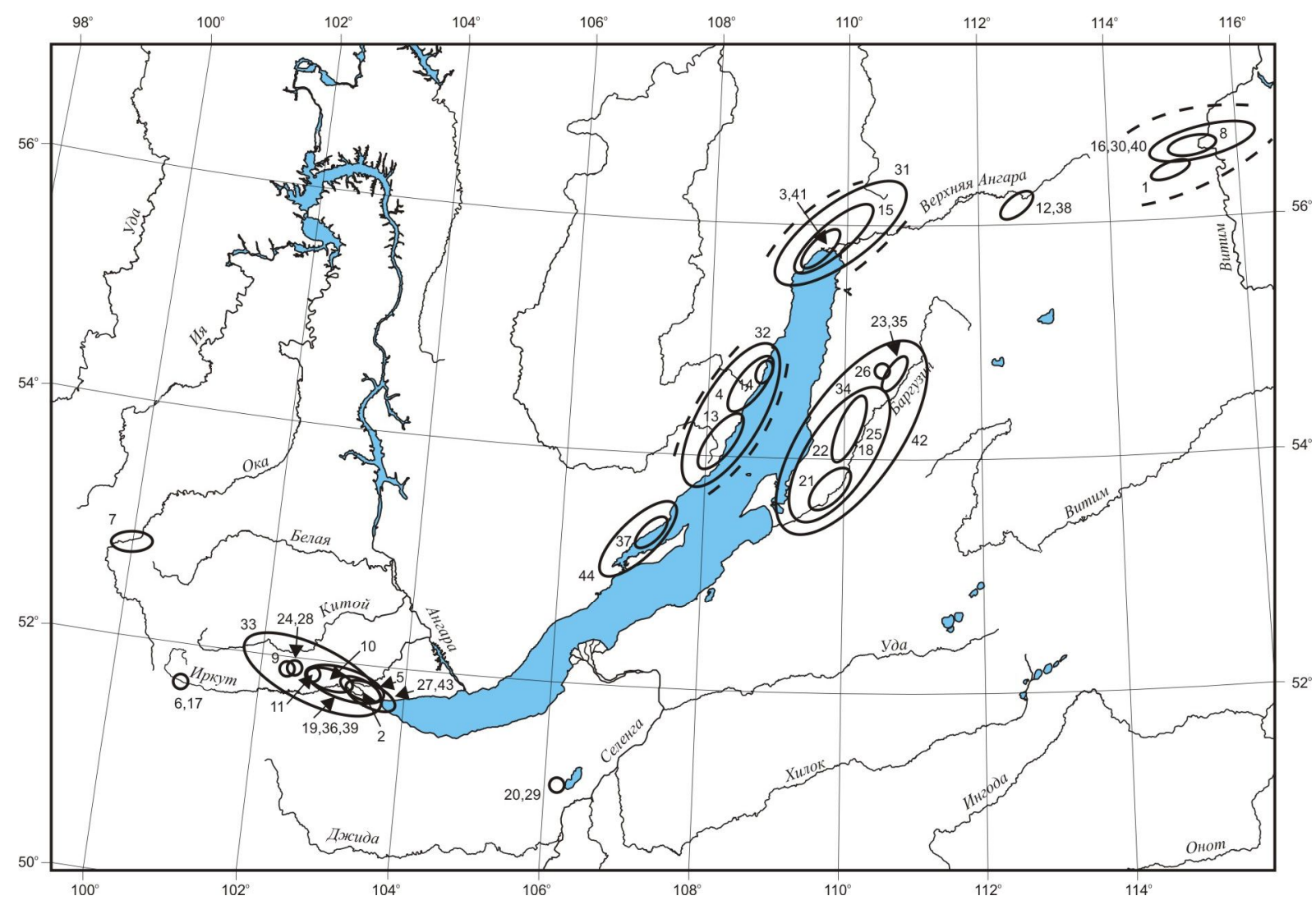

Рис. 3.18. Карта палеоземлетрясений Прибайкалья (Чипизубов и др., 2009

Номера палеоземлетрясений приведень согласно таблиць 3.3. Длинная ось эллипса соответствует протяженности вскрывшегося фрагмента разрыва. Площадь эллипса оконтуривает район возможного проявления вторичных сейсмогенных деформачий 
Таблица 3.3

Список палеоземлетрясений Прибайкалья

\begin{tabular}{|c|c|c|c|c|c|c|c|c|}
\hline \multirow{3}{*}{$\begin{array}{l}\text { № } \\
\Pi / \Pi\end{array}$} & \multirow{3}{*}{$\begin{array}{c}\text { Возраст события, лет } \\
\text { (крутизна уступов в } \\
\text { градусах) }\end{array}$} & \multirow{2}{*}{\multicolumn{2}{|c|}{$\begin{array}{c}\text { Координаты } \\
\text { центра }\end{array}$}} & \multirow{2}{*}{\multicolumn{3}{|c|}{$\begin{array}{c}\text { Амплитуда смещения } \\
\text { (D) в м }\end{array}$}} & \multirow{3}{*}{$\begin{array}{l}\text { Длина } \\
\text { (L) } \\
\text { в км }\end{array}$} & \multirow{3}{*}{$\begin{array}{c}\text { Магни- } \\
\text { туда } \\
\text { (M) }\end{array}$} \\
\hline & & & & & & & & \\
\hline & & & & $\begin{array}{l}\text { верти- } \\
\text { кальн. }\end{array}$ & гор. & $\begin{array}{l}\text { инте- } \\
\text { грал. }\end{array}$ & & \\
\hline 1 & 2 & \multicolumn{2}{|c|}{3} & 4 & 5 & 6 & 7 & 8 \\
\hline 1 & 1725 г? & 56.42 & 114.97 & 6 & & & 15 & $7.4-7.9$ \\
\hline 2 & $1742 \Gamma ?<438 ; 40^{\circ}$ & 51.75 & 103.55 & 0.5 & 1 & 1.1 & 40 & 7.1 \\
\hline 3 & $38-40^{\circ}$ & 55.77 & 109.57 & 6.5 & & & $>30$ & 7.6 \\
\hline 4 & $38-43^{\circ}$ & 54.47 & 108.57 & 6.5 & & & 75 & 7.9 \\
\hline 5 & $508-1071 ; 37^{\circ}$ & 51.75 & 103.55 & 1 & 5 & 5.1 & 46 & 7.7 \\
\hline 6 & $497-654$ & 51.68 & 100.95 & $?$ & & & $?$ & \\
\hline 7 & $679-797$ & 52.80 & 100.00 & 1.5 & 2 & 2.3 & 24 & 7.4 \\
\hline 8 & $37^{\circ}$ & 56.62 & 115.32 & 5 & & & 21 & 7.4 \\
\hline 9 & $1315-1742 ; 44^{\circ}$ & 51.90 & 102.37 & 0.9 & 1.8 & 2.0 & 10 & 7.3 \\
\hline 10 & $1406-2056 ; 30^{\circ}$ & 51.80 & 103.40 & 5 & 8 & 8.6 & 46 & 8.0 \\
\hline 11 & $2464-2809$ & 51.85 & 102.97 & 0.7 & 2.1 & 2.2 & 23 & 7.4 \\
\hline 12 & $34^{\circ}$ & 56.17 & 112.59 & 4 & & & 13 & 7.3 \\
\hline 13 & $31-36^{\circ}$ & 54.17 & 108.37 & 6 & & & 70 & 7.8 \\
\hline 14 & $31-36^{\circ}$ & 54.73 & 108.80 & 6 & & & 50 & 7.7 \\
\hline 15 & $32-35^{\circ}$ & 55.97 & 109.98 & 6.5 & & & 60 & 7.8 \\
\hline 16 & $30-33^{\circ}$ & 56.60 & 115.40 & 7.5 & & & $>21$ & 8.0 \\
\hline 17 & $<3360$ & 51.68 & 100.95 & $?$ & & & $?$ & \\
\hline 18 & $3574-3730$ & 54.17 & 110.14 & $?$ & & & $?$ & $(7.0)$ \\
\hline 19 & $3271-4435$ & 51.87 & 103.87 & $3-4$ & $7-8$ & 8.3 & 60 & 8.0 \\
\hline 20 & $<4299 ; 31^{\circ}$ & 51.13 & 106.18 & 2 & & & $2-3$ & 7.3 \\
\hline 21 & $3990-4840 ; 32-36^{\circ}$ & 53.75 & 109.13 & 6.5 & & & 45 & 7.7 \\
\hline 22 & $3990-4840 ; 32-36^{\circ}$ & 54.17 & 109.81 & 6.5 & & & 58 & 7.8 \\
\hline 23 & $3990-4840 ; 32-36^{\circ}$ & 54.61 & 110.58 & 6.5 & & & 33 & 7.6 \\
\hline 24 & $5257-5907$ & 51.92 & 102.47 & 0.45 & 1.35 & 1.5 & 34 & 7.2 \\
\hline 25 & $30^{\circ}$ & 54.10 & 110.10 & 5.5 & & & $?$ & 7.5 \\
\hline 26 & $30^{\circ}$ & 54.80 & 110.53 & 7 & & & 20 & 7.6 \\
\hline 27 & $6482-7681$ & 51.87 & 103.87 & $3-4$ & $7-8$ & 8.3 & 95 & 8.0 \\
\hline 28 & $7091-7385$ & 51.92 & 102.47 & 0.9 & 1.8 & 2.0 & 10 & 7.3 \\
\hline 29 & $>7668 ; 22-27^{\circ}$ & 51.13 & 106.18 & 4.5 & & & $2-3$ & 7.5 \\
\hline 30 & $24-30^{\circ}$ & 56.60 & 115.40 & $10-20$ & & & $>21$ & \\
\hline 31 & $\left(30^{\circ}\right)$ & 55.87 & 109.77 & $20-30$ & & & 95 & 10 \\
\hline 32 & $24-29^{\circ}$ & 54.43 & 108.42 & 24 & & & 150 & \\
\hline 33 & $8522-9500$ & 51.87 & 102.87 & $3-4$ & $7-8$ & 8.3 & 95 & 8.0 \\
\hline 34 & $9116-9305 ; 24^{\circ}$ & 54.83 & 110.58 & 6.5 & & & 124 & 8.1 \\
\hline 35 & $9116-9305 ; 24^{\circ}$ & 54.61 & 110.08 & 6.5 & & & 33 & 7.6 \\
\hline 36 & $8720-10074$ & 51.88 & 102.73 & 4.1 & 7.1 & 8.1 & 70 & 8.0 \\
\hline 37 & $20-24^{\circ}$ & 53.33 & 107.28 & 5 & & & 25 & 7.5 \\
\hline 38 & $22^{\circ}$ & 56.17 & 112.59 & & & & 13 & 7.3 \\
\hline 39 & 10386-11187 & 51.88 & 102.73 & 4.1 & 7.1 & 8.1 & 70 & 8.0 \\
\hline 40 & $20^{\circ}$ & 56.60 & 115.40 & $3-4$ & & & $?$ & \\
\hline 41 & $20-22^{\circ}$ & 55.87 & 109.77 & 6.5 & & & $?$ & 7.6 \\
\hline 42 & $20^{\circ}$ & 54.61 & 110.31 & 9.5 & & & 180 & 8.2 \\
\hline 43 & 12095-13049 & $(51.87$ & 103.87) & $?$ & & & $?$ & \\
\hline 44 & $15-19^{\circ}$ & 53.27 & 107.10 & 5 & & & 95 & 7.9 \\
\hline
\end{tabular}


Палеосейсмологическими исследованиями, кроме палеособытий с обычными амплитудами смещения от 2-3 до 6-7 м, выявлены раннеголоценовые палеосейсмодислокации с амплитудами аномального вертикального смещения в 15-20 м (Парамский разлом), в 24 м (Северобайкальский разлом) и в 20-30 м (Кичерский разлом), которые при отсутствии тренчинговых исследований могли бы предполагаться одноактными. Мощные (20-50 м), пока нерасчлененные сейсмогенные уступы, находятся в зонах Тункинского, Уколкитского и Баргузинского разломов. Симптоматично, что в зонах этих разломов, а также в зонах Приморского и Главного Саянского наиболее мощные палеоземлетрясения происходили 9-10 тыс. лет назад (Чипизубов и др., 2008). К этому же времени относится образование ПСД Малиновка на одной из ветвей С3 фланга зоны Главного Саянского разлома, связанная с сильнейшим (M=7.9-8.0) палеоземлетрясением (Аржанников и др., 2000).

\section{6. ПАЛЕОСЕЙСМОДИСЛОКАЦИИ ЯКУТИИ}

Для обнаружения сейсмодислокаций, подтверждающих активность выделенных разломов, использовался палеосейсмогеологический метод, основы которого заложены Н.А. Флоренсовым (1976) и В.П. Солоненко $(1962,1973)$, что позволило существенно дополнить немногочисленные данные сейсмостатистики, характеризующие высокий уровень сейсмической активности исследуемой территории. Одним из его основополагающих приемов является выявление на аэрофото и космоснимках морфологических следов палео и современных землетрясений. При этом определялись местоположение сейсмодислокаций, интенсивность (возможная магнитуда) землетрясения, при котором возникла дислокация, а также вероятное время ее возникновения, исходя из размеров дислокации, морфологической выраженности и типа первичных (сейсмотектонических) и вторичных (сейсмогравитационных) деформаций.

При анализе аэрофото и космонимков были выявлены участки, где обнаружены скопления сейсмодислокаций различного генезиса. В конечном счете, к настоящему времени на территории Восточной и Южной Якутии было обнаружено и описано порядка 28 сейсмодислокаций, связанных с палеокатастрофами. Наиболее характерные из них приведены ниже.

Наиболее ярким примером такой сейсмогенной структуры служит палеосейсмодислокация Бэрис, которая является северным продолжением трассы Хараулахского разлома. Она представлена прямолинейным секущим разрывом субдолготного простирания длиной 12 км, со сдвиго-сбросовым кинематическим типом движения (рис. 3.19). Смещения некоторых форм рельефа указывают на их преобладающий 
правобоковый характер. Несмотря на яркую выраженность основной трассы разлома, на аэрофотоснимках не дешифрируются свежие сейсмотектонические и сейсмогравитационные проявления.

При натурных наблюдениях обнаружено, что разлом представляет собой систему шириной 10-15 м. На склонах и вершинах водоразделов он выражен в виде ложбин шириной 4-6 м, внутри которых встречаются обломки аргиллитов и песчаников, перетертых в мелкую крошку. Края рвов-ложбин поднимаются крутыми $\left(80-90^{0}\right)$ отвесными стенками над их днищем на 2-2.5 м и сложены преимущественно обломками окварцованных плотных песчаников. Направление движения крыльев данного разрыва уверенно устанавливается по смещению субширотных притоков рек, а также осевых линий водораздельных хребтов. Амплитуда горизонтального смещения западного крыла этого разрыва составила 25-30 м. Смещением оказались затронуты самые молодые отложения флювиогляциального комплекса вплоть до пойменных и надпойменных террас. Указанные сведения, а также анализ трещиноватости пород в плоскости выявленного разлома позволили определить его кинематику как правый сдвиго-сброс. По комплексу возраст сейсмодислокации Бэрис оценен нами первой тысячью лет при расчетной магнитуде землетрясения 7.2-7.5.

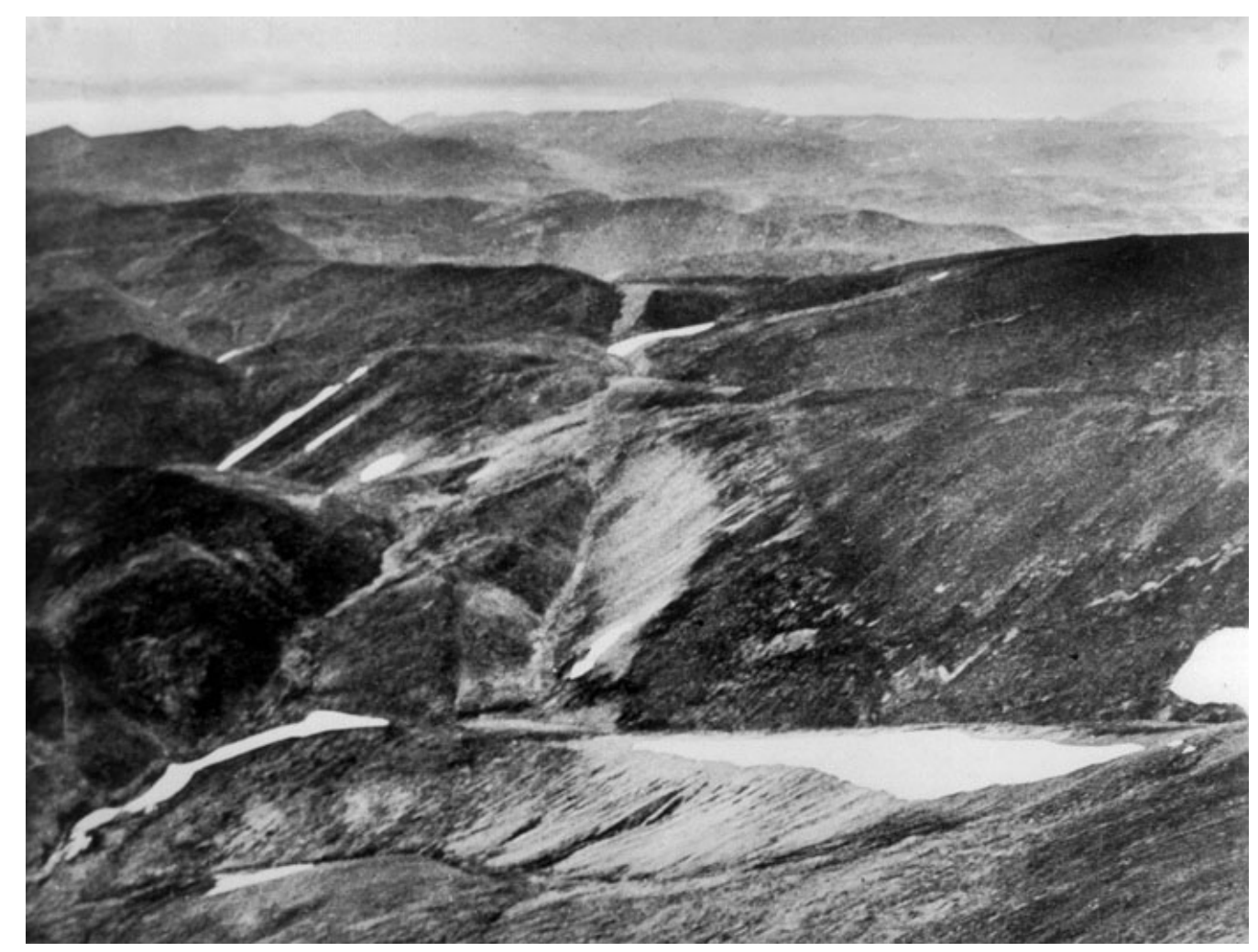

Рис. 3.19. Сейсмодислокация Бэрис в виде системы рвов, вскрытых на земной поверхности при Булунских землетрясениях 1927-1928 г2. (M=7.0) 
Особо впечатляет среди них сейсмогенная плотина, которая была обнаружена на северо-западном фланге системы разлома Улахан (бассейн р. Тирехтях, левый приток р. Мома) Г.С. Гусевым во время проведения работ картированию зон разломов. Им была задиагностирована обвальная плотина высотой до 55-70 метров, перекрывающая один из правых притоков Тирехтяха (р. Ерюн-ТасТах) (Мокшанцев и др., 1977). Образовавшееся, вследствии землетрясения озеро, затем было спущено за счет прорыва этой плотины (рис. 3.20). Согласно радиоуглеродным определениям возраста обломков древесины, обнаруженных в основании этого обвала предполагаемый возраст палеоземлетрясения соответствует рубежу в 1000-1110 лет (Важенин, 1992, 2000).
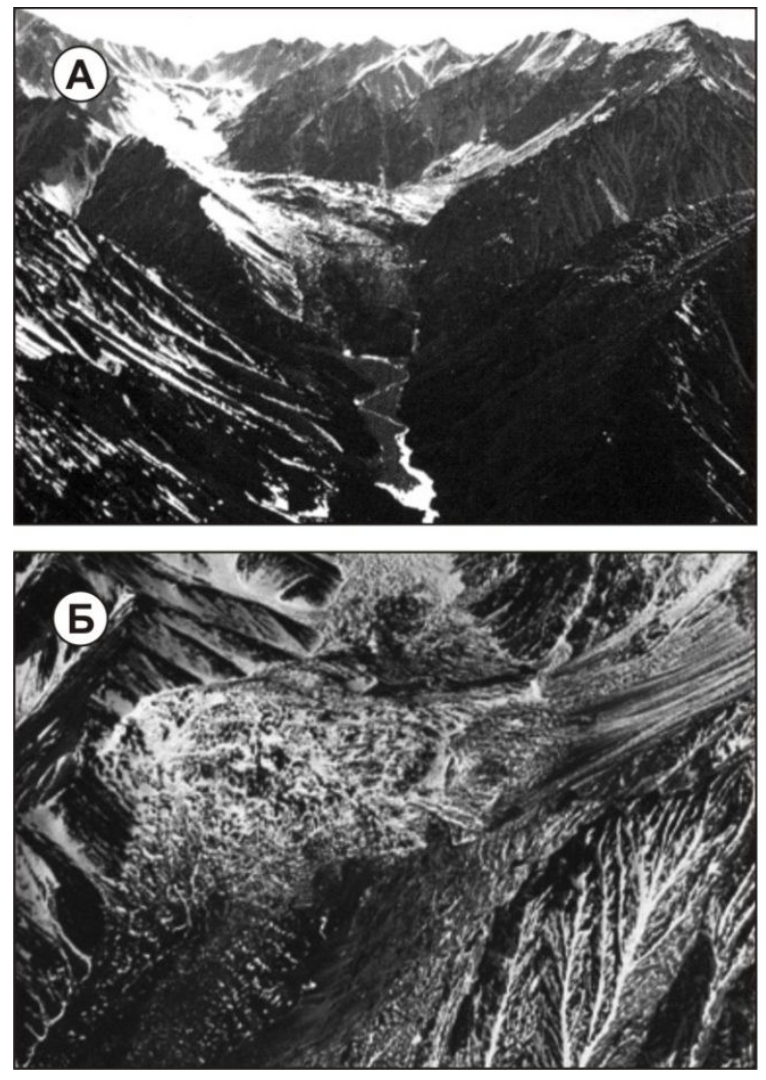

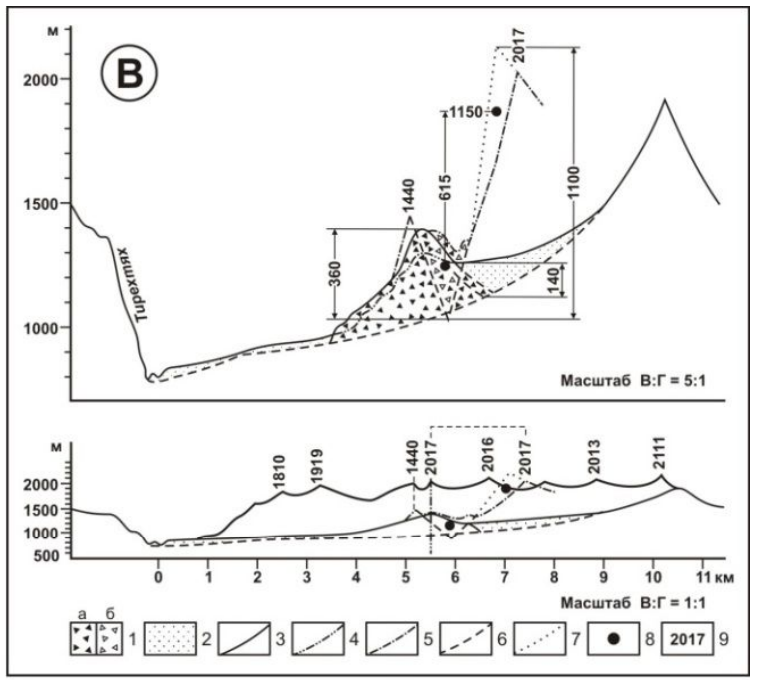

(Г)

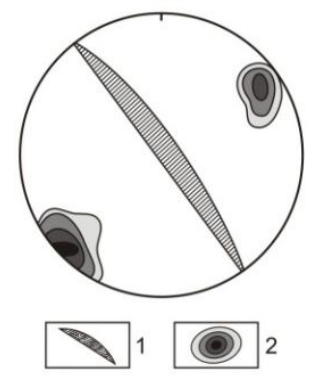




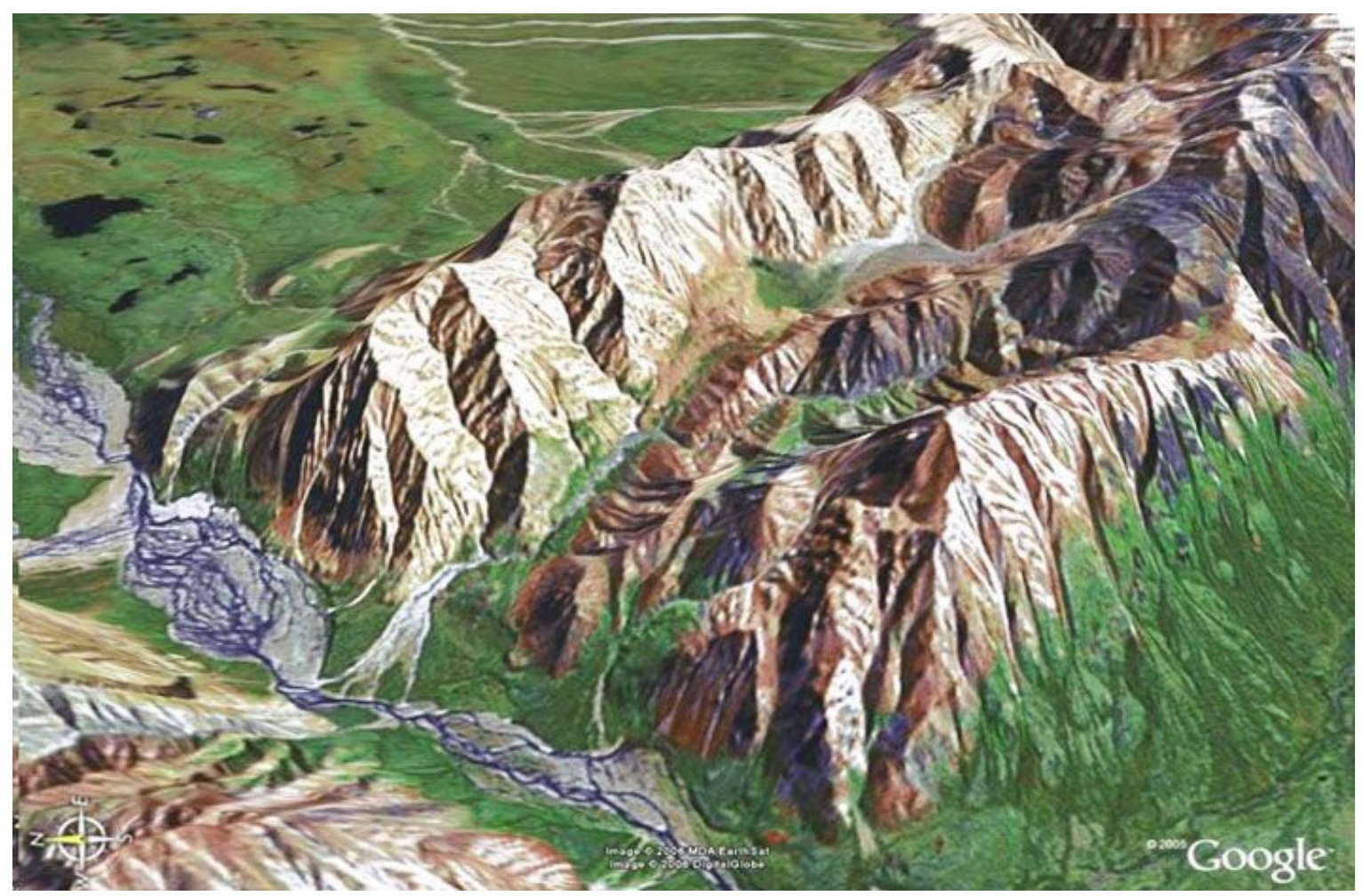

Рис. 3.20. Сейсмогенная плотина Ерюн-ТасТах (левый приток р. Мома)

$A$ - вид спереди (видно, что плотина перекрывает верховья р. Ерюн-Тас-Тах);Б - вид сверху (видно тело обвала, перекрывщего долину реки и стенку отрыва);B - поперечный профиль, проведенный через сейсмогенную плотину (по (Б.П. Важенин, 1992, 2000)); 1 - плоскость активного разлома; 2 - изолинии плотности трещчин в круговых диаграммах трещчиноватости горных пород. Трехмерная модель рельефа района сейсмогенной плотины, полученная при помощи материала поисковой системы «Google». Стрелками показана сама плотина и залегающее выше нее тело обвала

В ходе выполнения исследовательских работ по изучению сейсмической опасности и современной геодинамики Токинского Становика (восточная часть Алдано-Станового блока) аэровизуально был обнаружен отчетливый сейсмогенный скарп в окрестностях р. Б. Туксани (Токинский Становик), что указывает на высокую сейсмическую активность этой территории в недалеком геологическом прошлом (рис. 3.21). 


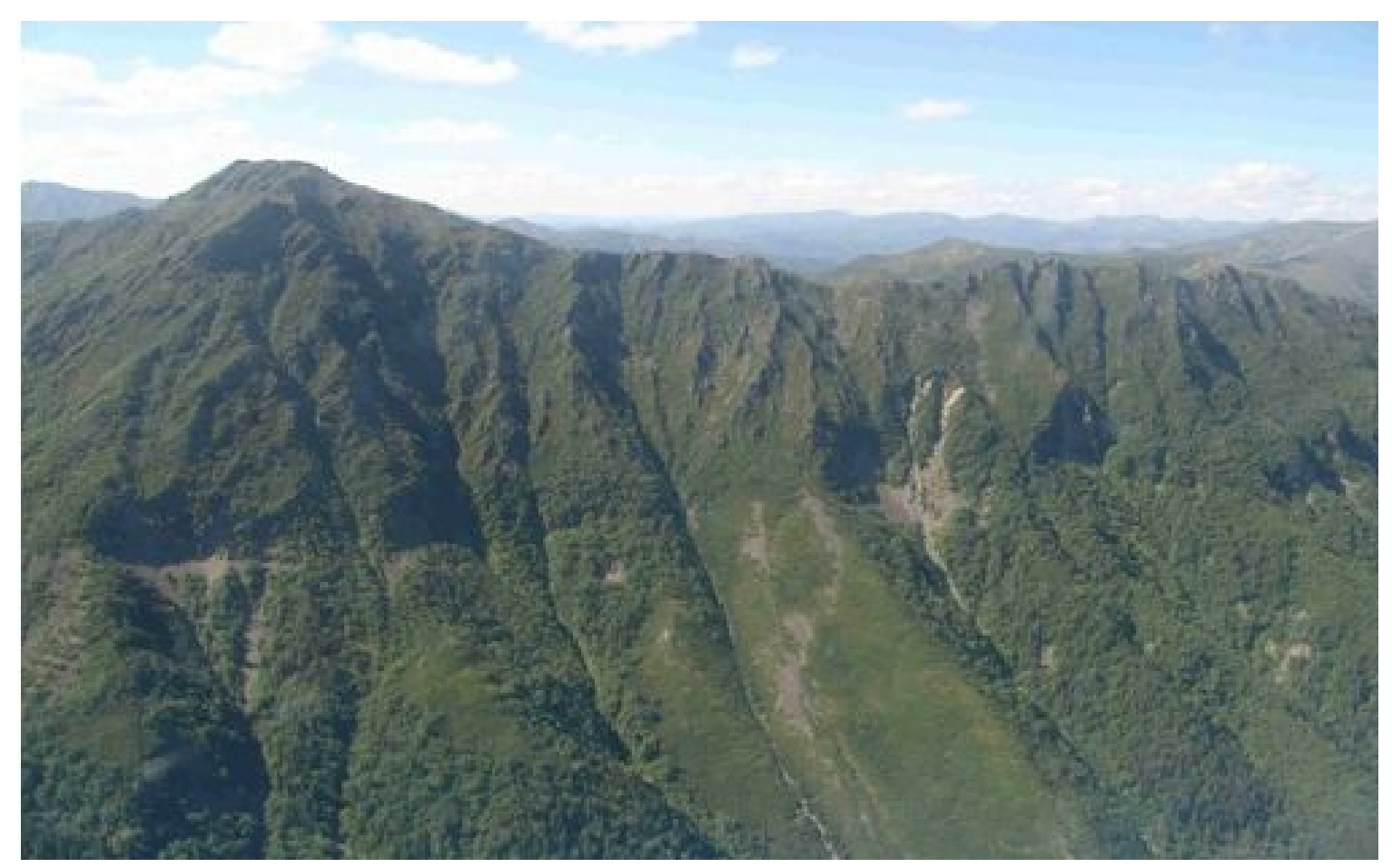

Рис. 3.21. Сейсмогенный скарп в районе Токинского Становика (верховья р. Б. Туксани)

В результате детальных маршрутных исследований 1984 г. была выявлена значительная по размерам палеосейсмогенная структура, расположенная вблизи устья р. Алгамы (бассейн р. Учур) (рис. 3.22). Предварительно указанная структура была обнаружена нами на аэрофотоснимках и топографических картах, как аномально выраженная в рельефе. При полевом обследовании водораздела в устье рек Алгамы и Гонама (бассейн р. Учур) выяснилось, что блок протерозойских песчаников (гонамская свита) был сдвинут по разлому северо-западного направления (азимут простирания 320-325) на 150 м (установлено по смещению водораздельной линии) к востоку - юго-востоку таким образом, что отчасти перегородил субдолготную прямолинейную долину р. Алгамы. 


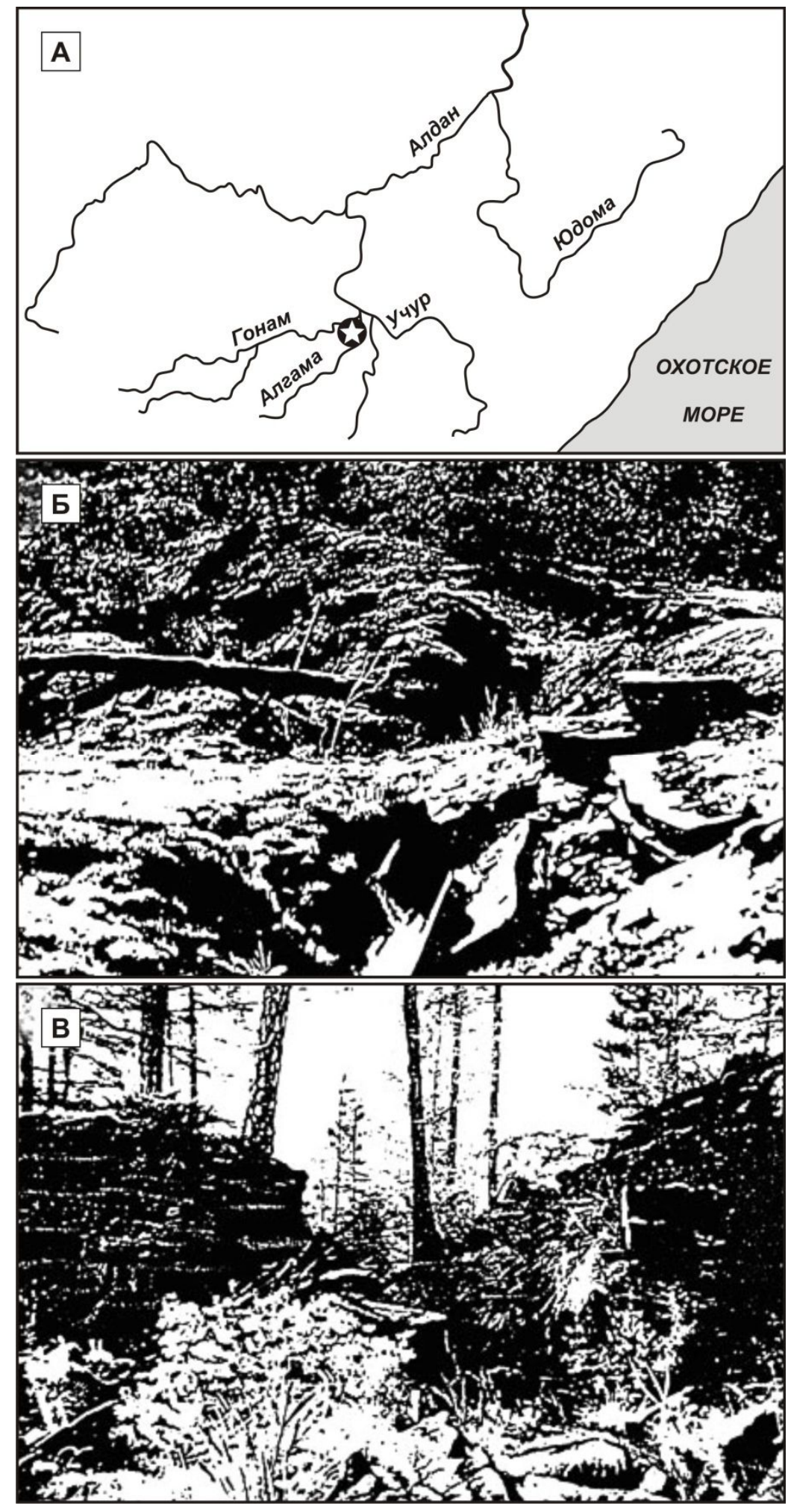

Рис. 3.22. Сейсмодислокация «Алгама»

$A$ - местоположение дислокации (помечено звездочкой); 5 - сейсмогенные pвы; $B$ - зона разлома

Отторженец имеет размеры - 0.7x1.5 км, с залеганием пород $170^{\circ}$, угол падения $15^{\circ}$, в то время как в основной части водораздела коренные породы имеют азимут простирания $7^{\circ}$. Пространство водораздела между отторженцем и материнским блоком (в тылу отрыва) разбито системой кулисообразных трещин, морфологически выраженных сейсморвами 
(простирание $320^{\circ}$ ), заполненных делювиальным материалом, перекрывающим в названных рвах почвенный слой. Такие нарушения земной поверхности могут указывать на их сейсмогенный характер. Зона отрыва занимает по ширине примерно 1.5 км, наблюдаемая частота трещин отрыва составляет одна на 20-25 м, при их ширине 2.0-2.5 м. Рвы имеют резкие прямые стенки, по их краям в протерозойских песчаниках развиты зеркала скольжения со сбросо-сдвиговыми смещениями (азимут падения 500, угол падения 85-90). Видимая амплитуда горизонтального перемещения между соседними рвами 3-6 м. Тип смещения - правый сдвиг с простиранием на восток-юго-восток. На дне этих рвов растут кустарники и молодые лиственницы 50-60-летнего возраста, в то время как на водоразделе, в основном, распространены лиственничные деревья с возрастом 200-300 лет. Оценка возраста выполнена по спилам деревьев с помощью подсчета годовых колец. Плоскость разлома хорошо фиксируется и на противоположном (правом) борту р. Алгамы. Здесь (по азимуту $320^{\circ}$ ) наблюдается ров глубиной 10-12 м и шириной 10-15 км. Далее ров продолжается на юго-восток и его следы отмечены на протяжении всего водораздельного склона вплоть до вершины.

При нанесении координат исследуемого места на карту эпицентров землетрясений, возникло предположение, что данное образование, возможно обусловлено сильным землетрясением конца прошлого века (Новый каталог..., 1977). Оно в донесении Иркутской магнитно-метеорологической обсерватории зафиксировано как значительное сейсмическое событие, происшедшее 8 августа 1895 г., в «Якутской области по реке Учуру притоку Алдана в 40 верстах от стойбища Учур, которое находится при пересечении Учура дорогой с Алдана на Удский Острог. Здесь тунгусы наблюдали сильное землетрясение, во время которого катились с гор камни и валялись деревья». Землетрясение продолжалось с перерывами от 8 августа до 20 октября 1895 года. Дислокация подобного вида и размера, согласно сейсмогеологических исследований В.П. Солоненко и др. (Живая тектоника..., 1966), имеет, вероятно, сейсмогенное происхождение и может возникнуть при землетрясении с магнитудой 7.0 (интенсивность сотрясения в эпицентре землетрясения не менее 9 баллов). 


\section{ГЛАВА 4. НЕОТЕКТОНИЧЕСКИЕ И \\ СЕЙСМОГЕОДИНАМИЧЕСКИЕ ИССЛЕДОВАНИЯ \\ ВОСТОЧНОЙ СИБИРИ}

\section{1. ГЛАВНЫЕ ПРИНЦИПЫ ВЫДЕЛЕНИЯ ГЕОДИНАМИЧЕСКИ АКТИВНЫХ НЕОТЕКТОНИЧЕСКИХ СТРУКТУР}

В основу сейсмотектонических исследований положена концепция о структурнодинамическом единстве геофизической среды и закономерно развивающихся в ней сейсмогеодинамических процессах, методические основы которой разработаны в Институте физики земли РАН (Уломов, 1995; Shebalin et al., 1995; Уломов, Шумилина, 1998), а в дальнейшем дополнены (Уломов, 2011; Гусев, Имаева, 2012; 2014). В региональном плане они адаптированы и модифицированы сотрудниками лаборатории инженерной сейсмологии и сейсмогеологии Института земной коры СО РАН (Чипизубов и др., 2008, 2009; Имаев и др., 1990, 1994, 1998, 1999, 2000, 2001, 2007, 2013; Смекалин и др. 2007, 2010; Имаева и др., 2000, 2010, 2011, 2012, 2013; 2014).

При выполнении исследований по сейсмическому районированию на территории Восточной Сибири (Монгольский, Алтай-Саяно-Байкальский, Верхоянский, Арктический и Приамуро-Приморский сейсморегионы) авторским коллективом был разработан и апробирован комплексный подход для решения задач сейсмотектонического анализа в зонах сейсмогенерирующих структур с различным типом геодинамического режима. Он базируется на структурно-геометрическом изучении деформаций в зонах с определенным типом напряженного состояния земной коры и выявлении закономерностей формирования очаговых зон сильных землетрясений.

Составными частями этого метода являются проведение детальных работ по установлению структурных парагенезисов активных разломов и типов позднекайнозойских складчатых и разрывных деформаций, изучение структурно-тектонической позиции основных эпицентральных полей; крупномасштабные тектонофизические, палеосейсмологические, морфотектонические и неотектонические исследования, морфометрические построения, дешифрирование крупномасштабных дистанционных материалов и снимков лазерного сканирования. Для создания региональных сейсмогеодинамических моделей были применены новые геоинформационные системы управления электронной базой данных сейсмотектонических параметров, в атрибутивных таблицах которых даны их основные геолого-геофизические и сейсмотектонические параметры. Как показывает опыт международных совместных иссле- 
дований, именно такой набор фактических данных обеспечивает наиболее обьективную информацию о происходящих сейсмогеодинамических процессах.

Главной целью сейсмотектонических и сейсмогеодинамических исследований настоящей работы является выявление и сейсмологическая параметризация сейсмогенерирующих структур (СГС) на территории Восточной Сибири и в сопредельных регионах для создания трехмерной модели зон ВОЗ. Зоны ВОЗ выделяются и параметризуются путем комплексного анализа сейсмологических и сейсмотектонических данных на первоначальной основе выделения и параметризация геодинамически активных неотектонических зон (ГАНЗ), которые могут генерировать землетрясения.

ГАНЗ, с позиции системного анализа, рассматривается как пространственно локализованный целостный объект с многофакторным взаимодействием его основных компонентов в разрезе земной коры и верхней мантии (литосфере) - корово-мантийный вариант; в разрезе литосферы и нижней мантии - суперглобальный вариант. Классификация ГАНЗ представляет собой систему, состоящую из 10 классов. Каждый из них характеризуется набором признаков: геодинамической обстановки формирования геологических структур; скоростями горизонтального (по данным GPS, геолгическим и геоморфологическим даным) и вертикального движения геологических тел (мм/год); размерами их пластических (пликативных) и разрывных деформаций; направлениями силовых тектонических полей; морфструктурными типами эндогенного рельефа суши морей, их высотами и значениями контрастности; геофизическими (величины теплового потока и поля силы тяжести, сейсмической томографии); глубинного строения (мощность земной коры, глубина залегания поверхности Мохоровичича и астеносферного слоя, мощность верхней и нижней мантии).

Необходимость анализа новейшей (позднеплиоценовой-четвертичой) структуры изучаемой территории определяется тем, что новейшая тектоника представляет собой тот структурный каркас, в который вписываются ГАНЗ и другие проявления молодой и, особенно, современной тектонической активности, с которой могут быть связаны сейсмические явления. Новейшая стадия неотектонического этапа, несмотря на относительно небольшую свою продолжительность, характеризуется более или менее значительной эволюцией и изменчивостью геодинамических условий, режима тектонических движений и структурного плана. По этой причине нужно определить тенденции этих изменений и опираться, прежде всего, на наиболее молодые элементы этого плана.

Неотектонический анализ, по самой сути новейшей тектоники, предусматривает выполнение широкого комплекса структурно-геоморфологических исследований, называемых также морфоструктурными. Главной их целью является установление закономерностей пространственного распределения высотной дифференциации земной поверхности, типов и ин- 
тенсивности ее эрозионно-денудационного расчленения, различных типов рельефа и коррелятных им отложений. Эти закономерности прямо или опосредованно отражают формы неотектонических структур, позволяют осуществить структурно-геоморфологическое районирование территорий и выделять аномальные зоны с повышенными градиентами изменений характеристик земной поверхности. Их сопоставление с результатами структурногеологического анализа, геофизическими данными (аномалиями геофизических полей) и геодинамический контроль позволяют намечать различного рода и разных рангов ГАНЗ.

Эти исследования включают разноранговый анализ топографических карт, масштаб которых изменяется от 1:2500000 до 1:100000, аэрофотоснимков и космических изображений также разных масштабов, пространственного разрешения и территориального охвата. Для указанных целей весьма полезны также цифровые модели рельефа (DEM) с разрешением 30" и 3", соответствующие масштабам топографических карт примерно 1:1000000-1:500000 и 1:100000. В качестве априорной информации должны быть использованы геологические, структурные, палеотектонические, неотектонические и другие специальные карты и материалы, в том числе характеризующие строение глубинных слоев коры и верхней мантии.

Одной из главных проблем, связанных с выявлением новейших ГАНЗ на платформах, является связь глубинных и приповерхностных, древних и молодых структур платформенных территорий (степень и формы связи, пространственные и временные закономерности). Такой анализ неизбежно требует рассмотреть платформу вместе с обрамляющими ее подвижными областями, с которыми платформа находится в достаточно известном или прогнозируемом динамическом взаимодействии и которые оказывают на нее более или менее далекое воздействие (Макаров, 1996).

В таком случае ГАНЗ могут быть квалифицированы по разным параметрам: по протяженности, ширине, структурно-морфологическому типу, интенсивности проявления, глубинности заложения, рангу, характеру напряженного состояния в ее пределах (отвечающему сжатию, растяжению, сдвигу или какому-то промежуточному), степени наследования и соответствия древним структурным элементам, дальности нахождения от активных элементов системы, которой они принадлежат и с которыми они, может быть, генетически связаны, по соответствию гравитационным, магнитным и тепловым аномалиям и ряду других параметров. На их основе выполняется сравнительное ранжирование ГАНЗ по своему энергетическому и сейсмическому потенциалу. Для разных частей платформ эти оценки могут различаться.

Необходимость анализа новейшей позднекайнозойской (позднеплиоценовочетвертичной) структуры изучаемой территории определялся тем, что новейшая тектоника представляет собой тот структурный каркас, в который вписываются активные разломы и 
другие проявления современной тектонической активности, напрямую связанные с региональной сейсмичностью. Поскольку в ходе длительного развития новейшей структуры происходили ее изменения, нужно определить тенденции этого развития и выделить те структурные элементы, которые возникли или продолжали унаследовано развиваться в его позднеплиоценовую-четвертичную стадию. Именно такие структурные элементы чаще всего характеризуются проявлениями активной тектоники, и в местах их распространения следует сосредоточить поиски активных разломов и других форм новейшей тектонической активности.

Содержание этого нового термина в сейсмотектоническом анализе в существенной мере определяется ключевыми словами, которые составляют понятие «геодинамически активная неотектоническая зона». Это геодинамика (геодинамический), активность (активный), неотектоника и зона

Следует напомнить, что геодинамика согласно Строительным нормам и правилам (1981) - это раздел тектоники, изучающий силы, действующие на планету и ее оболочки, и явления, которые имеют место на ее поверхности; или раздел общей геотектоники, изучающий динамику земной коры или Земли и исследующий физические условия тектонических движений и деформаций.

По С.В. Аплонову (2001), геодинамика определена как наука о физической сущности процессов эволюции твердой Земли. Конечная ее цель - на основе известных геологогеофизических фактов, используя фундаментальные законы физики и современный математический аппарат, построить непротиворечивую модель эволюции нашей планеты. Д.Л. Теркот и Дж. Шуберт (1985) определяют геодинамику как науку, изучающую движения и деформации, происходящие в земной коре, мантии и ядре, и их причины.

В современной геодинамике выделяют ту ее часть, которая изучает современное, (от первых лет до первых сотен лет) геодинамическое состояние земной коры, процессы пространственно-временного перераспределения вещества и энергии в земной коре (движения и упругие деформации, тепломассоперенос) и различные формы проявления этих процессов. При этом нередко имеют в виду процессы, которые изучаются с помощью инструментальных повторных или непрерывных наблюдений (Сидоров и др., 2000). Физическая же его суть, физические условия, порождающие деформации земной коры, при этом фактически не подразумеваются, являясь объектом рассмотрения или, по крайней мере, учета в основном в специальных работах тектонофизического содержания. В связи с развитием и широким распространением концепции тектоники литосферных плит, в которой геодинамические построения и реконструкции занимают ключевое место, использование термина «геодинамика» 
было в значительной мере монополизировано и распространено не только в область тектоники, но и в области литолого-фациального анализа, стратиграфии.

Согласно определению Н.А. Логачева с соавторами (1991), под активностью понимается мера суммарного комплексного воздействия на литосферу или земную кору многокомпонентной системы частных эндогенных процессов, приводящих к последовательному преобразованию ее структуры. Она фиксируется отклонением от некоторого уровня интенсивности проявления основных тектонических процессов и их параметров: скоростей и амплитуд движений, теплового потока, магматизма, сейсмичности и некоторых других, косвенно отражающих мощность литосферных энергетических источников.

В работах С.И. Шермана с коллегами впервые был предложено понятие геодинамически активная литосфера ГАЛА (Шерман и др., 1999). Их причинно-следственные связи, взаимообусловленность и вклад каждого из соответствующих параметров в суммарную оценку геодинамической активности литосферы (или только земной коры, или менее крупных ее слоев и объемов) далеко не всегда поддаются количественному определению.

Попытки применения оценок комплексного анализа геолого-геофизических материалов неоднократно предпринимались ранее и были предложены Г.И. Рейснером с соавторами, предложившими внерегиональный метод анализа активности (сейсмической) структур литосферы, представлявший собой комплексную оценку активности при помощи учета комплекса геолого-геофизических данных (Рейснер и др., 1980, 1993; Гитис и др., 1986).

Зона - широко используемый термин, обозначающий участок земной поверхности или, точнее, некоторый объем земной коры или литосферы, характеризуемый каким-либо общим признаком или совокупностью признаков, генетически связанных с вещественными, структурными и/или геодинамическими особенностями, выделяющими его из окружающего пространства. В литературе встречаются весьма разнообразные понятия, связанные с термином «зона» в его геодинамическом значении: зона разломов, зона глубинных разломов, зона смятия, зона динамического влияния разломов, активные геодинамические зоны, деструктивные зоны, зоны скалывания, зоны дробления, зоны активизации; тектонически активизированные зоны земной коры, деформационные зоны, мобильные зоны, неомобильные зоны, лабильные зоны, активные зоны платформ, сейсмогенерирующие, сейсмогенные, сейсмоактивные и сейсмоопасные зоны.

Ниже нами приводятся главные принципы выделения геодинамически активных неотектонических структур, используемые при сейсмотектоническом анализе территории, которые согласно методическим указаниям (Гусев и др., 2011; Гусев, Имаева, 2014) базировались на следующих утверждениях: 
І. Принцип системного анализа. Неотектоническая зона с позиции системного анализа рассматривается как целостный объект, структурно локализованный пространственновременным образом, с многофакторным взаимодействием его основных компонентов.

II. Принцип иерархической системности. Классификация неотектонических зон представляет собой многоуровненную систему, состоящую из 10 классов, характеризующихся дифференциацией активности геодинамической процессов. По степени интенсивности неотектонических движений они объединены в три группы:

А - (1-3) - классы низкой активности (1 - чрезвычайно низкой, 2 - очень низкой, 3 низкой);

Б - (4-6) - классы умеренной активности (4 - малоумеренной, 5 - среднеумеренной, 6 - повышенноумеренной);

В - (7-10) - классы высокой активности (7 - умеренновысокой, 8 - высокой, 9 очень высокой, 10 - чрезвычайно высокой).

Абсолютное значение цифрового кода определяется соблюдением принципа атрибутивности.

III. Принцип атрибутивности. Каждый класс неотектонической активности характеризуется свойственным ему набором признаков, представляющих геодинамическую обстановку формирования геологических структур в составе неотектонической зоны:

1 - структурно-вещественных (параметры площадей и объемов новейших осадочных и магматических геологических тел; параметры площадей, объемов и петрофизических характеристик осадочных и магматических геологических тел предшествующих этапов развития и их пликативных и метаморфических преобразований);

2 - разломных (параметры новейших разломов и их динамические и кинематические характеристики);

3 - геофизических (характеристики в пределах неотектонических зон: величины теплового потока; поля силы тяжести (гравимметрических) аномалий; глубин залегания кристаллического фундамента в пределах платформенных и пассивноокраинных единиц; мощностей земной коры; глубины залегания поверхности Мохоровичича; величины мощности верхней (литосферной) мантии; мощности астеносферного слоя; сейсмическая активность);

4 -морфоструктурных (качественные и количественные характеристики современного рельефа и их размерность, направленность, интенсивность и контрастность вертикальных и горизонтальных движений).

IV. Принцип унаследованности. Особенности геодинамической активности неотектонических структур и граничных разрывных зон зависят от степени унаследованности струк- 
турных, кинематических и динамических особенностей формирования геологических тел предшествующих этапов развития (субстрата новейших структур).

V. Принцип объективизации и взаимообусловленности. Для характеристики признаков геодинамической активности неотектонических структур использованы только достоверные исходные данные, взаимообусловленных геологических процессов и явлений.

VI. Принцип унификации - единство плана информационного языка описания всех признаков каждого класса геодинамической активности неотектонических структур.

VII. Принцип многосторонности. Привлечение для каждого класса геодинамической активности неотектонических структур возможно большого числа геологических, геофизических, геохимических, геодезических, дистанционных признаков и GPS данных.

VIII. Принцип оптимизации сопоставимости. Использование для характеристики каждого класса геодинамической активности неотектонических структур наиболее оптимальных и сопоставимых, т.е. необходимых и достаточных признаков.

Ниже приводятся характеристики классов активности неотектонических структур в зависимости от конкретной геодинамической зоны, в которой проводятся эти исследования (табл. 4.1).

Таблица 4.1

Основные характеристики классов активности неотектонических структур в различных тектонически

\begin{tabular}{|c|c|c|c|c|c|c|c|c|c|c|c|c|}
\hline \multirow{3}{*}{$\begin{array}{c}\text { Геодина- } \\
\text { мический } \\
\text { тип зоны }\end{array}$} & \multirow{3}{*}{$\begin{array}{c}\text { Разновидности тектонических } \\
\text { обстановок геодинамических } \\
\text { групп и признаки неотектониче- } \\
\text { ской } \\
\text { активности классов }\end{array}$} & \multicolumn{10}{|c|}{$\begin{array}{c}\text { Группы и классы неотекто- } \\
\text { ническойактивности }\end{array}$} & \multirow{3}{*}{$\begin{array}{l}\text { Эталонные } \\
\text { зоны }\end{array}$} \\
\hline & & \multicolumn{3}{|c|}{$\begin{array}{c}\text { Низкой } \\
\text { актив- } \\
\text { ности }\end{array}$} & \multicolumn{3}{|c|}{$\begin{array}{c}\text { Уме- } \\
\text { ренной } \\
\text { актив- } \\
\text { ности }\end{array}$} & \multicolumn{4}{|c|}{$\begin{array}{l}\text { Высокой } \\
\text { активности }\end{array}$} & \\
\hline & & 1 & & 3 & 4 & 5 & 6 & 7 & 8 & 9 & 10 & \\
\hline \multicolumn{13}{|c|}{ А. Континентальная внутриплитовая группа } \\
\hline \multirow{5}{*}{$\begin{array}{c}\text { 1. Плат- } \\
\text { форменные }\end{array}$} & $\begin{array}{l}\text { 1.1. Поднятия относительно вы- } \\
\text { сокие (500-2000м) }\end{array}$ & & + & + & + & + & & & & & & Сибирская \\
\hline & $\begin{array}{l}\text { 1.2. Поднятия умеренные } \\
\text { и низкие }(0-500 \text { м) }\end{array}$ & + & + & + & & & & & & & & Западно-Сибирская \\
\hline & $\begin{array}{l}\text { 1.3. Опускания умеренные } \\
(0-500 \mathrm{M})\end{array}$ & + & + & & & & & & & & & Карская \\
\hline & 1.4. Опускания глубокие (>500) & & & & & & + & & & & & $\begin{array}{c}\text { Предверхоянский } \\
\text { прогиб }\end{array}$ \\
\hline & 1.5. Краевые прогибы (>1000) & & & & + & + & & & & & & Скифская \\
\hline \multirow{2}{*}{$\begin{array}{l}\text { 2. Внутри- } \\
\text { континен- } \\
\text { тальные } \\
\text { рифтовые }\end{array}$} & 2.1. Рифтовые троги (долины) & & & & & & & & + & + & + & Байкальская \\
\hline & 2.2. Плечи рифтов & & & & & & & & & + & & $\begin{array}{l}\text { Хамардабан- } \\
\text { Баргузинская }\end{array}$ \\
\hline \multirow{3}{*}{$\begin{array}{l}\text { 3. Пассивно- } \\
\text { окраинные }\end{array}$} & $\begin{array}{l}\text { 3.1. Окраинноконтинентальные } \\
\text { рифты }\end{array}$ & & & & & & & & + & & & $\begin{array}{l}\text { Центрально- } \\
\text { Лаптевская }\end{array}$ \\
\hline & 3.2. Шельфы & & & + & + & & & & & & & Восточно-Сибирская \\
\hline & 3.3. Прибрежные низменности & & & & & + & + & & & & & $\begin{array}{c}\text { Индигиро- } \\
\text { Нижнеколымская }\end{array}$ \\
\hline
\end{tabular}




\begin{tabular}{|c|c|c|c|c|c|c|c|c|c|c|}
\hline \multicolumn{11}{|c|}{$\begin{array}{l}\text { Б. Группа дивергентных границ литосферных плит и } \\
\text { внутриплитовой океанической структуры дна океана }\end{array}$} \\
\hline \multirow{4}{*}{$\begin{array}{l}\text { 4. Океани- } \\
\text { ческие }\end{array}$} & $\begin{array}{l}\text { 4.1. Океанические рифты и сре- } \\
\text { динноокеанические хребты }\end{array}$ & & & & & & & + & & Хребет Гаккеля \\
\hline & $\begin{array}{l}\text { 4.2. Абиссальные равнины океа- } \\
\text { нов с мощным } \\
\text { осадочным чехлом }\end{array}$ & & & & & & + & & & $\begin{array}{c}\text { Котловина Амундсе- } \\
\text { на }\end{array}$ \\
\hline & 4.3. Океанические валы & & & & & & & + & & Вал Зенкевича \\
\hline & $\begin{array}{l}\text { 4.4. Океанические } \\
\text { пассивные поднятия }\end{array}$ & & & & & & & + & & Поднятие Обручева \\
\hline \multicolumn{11}{|c|}{ В. Группа конвергентных границ литосферных плит (надсубкционная) } \\
\hline \multirow{4}{*}{$\begin{array}{c}\text { 5. Повтор- } \\
\text { ного горо- } \\
\text { обра-- } \\
\text { зования } \\
\text { (дейтеро- } \\
\text { орогенные) }\end{array}$} & $\begin{array}{l}\text { 5.1. Внутриплитовые орогены } \\
\text { нерасчлененные }\end{array}$ & & & & & + & + & + & + & Байкало-Витимская \\
\hline & $\begin{array}{l}\text { 5.2. Крупные впадины и прогибы } \\
\text { внутриплитовых орогенов }\end{array}$ & & & & & + & + & + & & Монголо-Охотская \\
\hline & $\begin{array}{l}\text { 5.3. Окраинноплитовые орогены } \\
\text { нерасчлененные }\end{array}$ & & & & & + & + & & & Верхояно-Колымская \\
\hline & $\begin{array}{l}\text { 5.4. Крупные впадины и прогибы } \\
\text { окраинноплитовых орогенов }\end{array}$ & & + & + & + & & & & & Колымо-Омолонская \\
\hline \multirow{2}{*}{$\begin{array}{c}\text { 6. По- } \\
\text { кровно- } \\
\text { складчатые }\end{array}$} & 6.1. Аккреционно-колизионные & & & & & & + & & & Кавказская \\
\hline & $\begin{array}{l}\text { 6.2. Аккреционно-колизионно- } \\
\text { активноокраинные }\end{array}$ & & & & & & & + & + & $\begin{array}{l}\text { Корякско- } \\
\text { Камчатская }\end{array}$ \\
\hline \multirow{4}{*}{$\begin{array}{l}\text { 7. Острово- } \\
\text { дужные }\end{array}$} & 7.1. Террейны океанических плит & & & & & & + & & & Алеутская котловина \\
\hline & $\begin{array}{l}\text { 7.2. Аккреционные призмы, } \\
\text { внешние дуговые поднятия и } \\
\text { преддуговые прогибы }\end{array}$ & & & & & & & & + & Малокурильская дуга \\
\hline & $\begin{array}{l}\text { 7.3. Вулкано-плутонические ост- } \\
\text { ровные дуги и их террейны }\end{array}$ & & & & & & & + & + & Алеутская дуга \\
\hline & $\begin{array}{l}\text { 7.4. Глубоководные } \\
\text { задуговые бассейны }\end{array}$ & & & & & & + & & & $\begin{array}{l}\text { Командорская котло- } \\
\text { вина }\end{array}$ \\
\hline \multirow{2}{*}{$\begin{array}{c}\text { 8. Шель- } \\
\text { фовые заду- } \\
\text { говые бас- } \\
\text { сейны }\end{array}$} & $\begin{array}{l}\text { 8.1. Поднятий и } \\
\text { неглубоких опусканий }\end{array}$ & & & & & + & & & & Беринговская \\
\hline & 8.2. Глубоких опусканий & & & & & + & + & & & Охотская \\
\hline \multicolumn{11}{|c|}{ Г. Трансформная граница литосферных плит } \\
\hline $\begin{array}{l}\text { 9.Транс- } \\
\text { формный } \\
\text { разлом }\end{array}$ & 9.1. Трансформный разлом & & & & & & & + & & Хребет Гаккеля \\
\hline
\end{tabular}

\section{2. СОСТАВНЫЕ ЭЛЕМЕНТЫ КАРТЫ СЕЙСМОТЕКТОНИКИ ВОСТОЧНОЙ СИБИРИ}

В результате, приведенных выше, методических приемов, построений и предшествующих схем, приводимых в работах Г.С. Гусева и Л.П. Имаевой, 2011, 2014; Уломова, 2011, нами была получена оценка активности неотектонических структур для территории Восточной Сибири (рис. 4.1). 


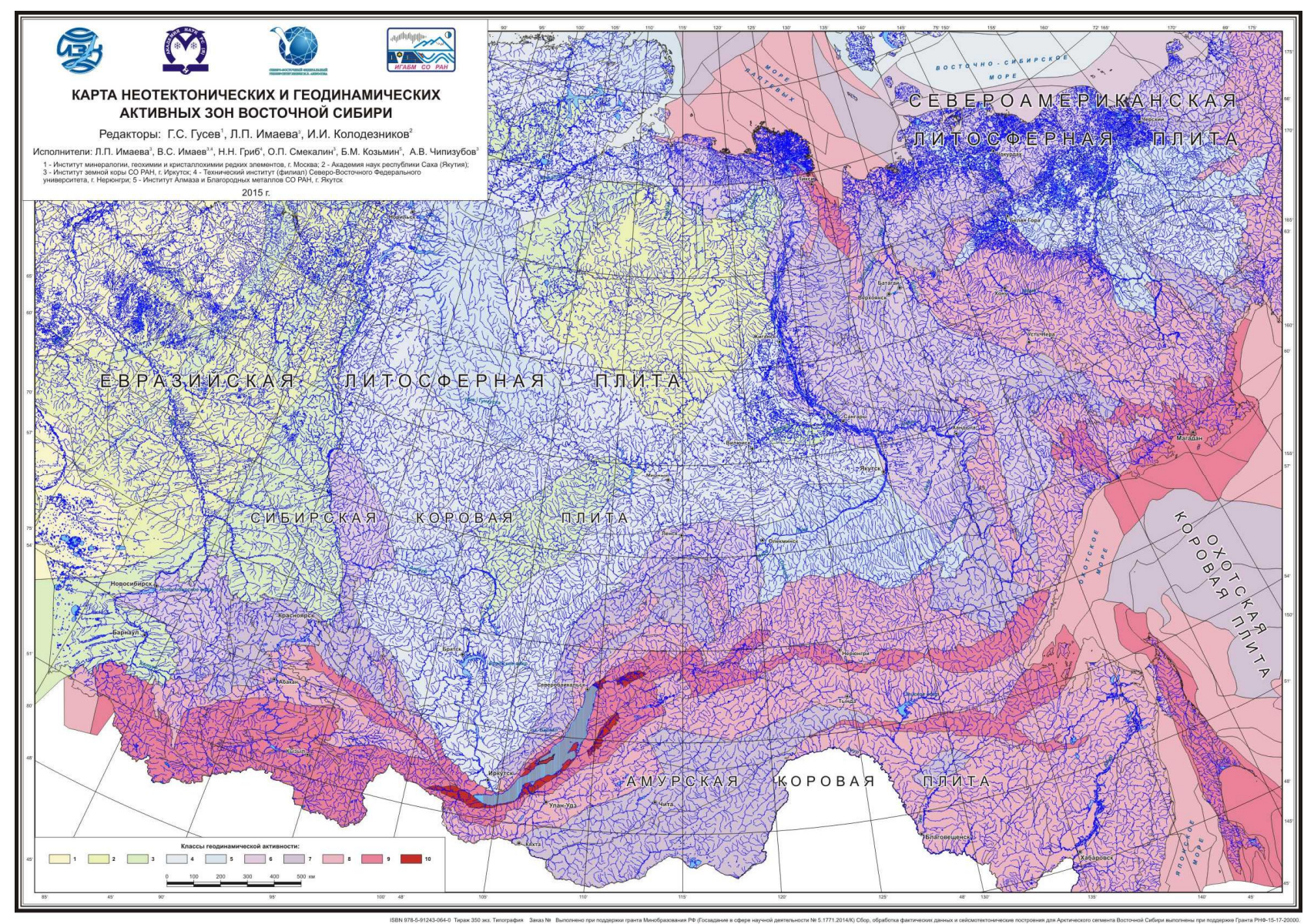

Рис. 4.1. Карта неотектонических геодинамических активных зон Восточной Сибири

Плановое распределение эелементов ГАНЗ в пределах Восточной Сибири показывает, что наиболее высокими показателями активности характерны для южной границы Сибирской платформы (Южно-Сибирский орогенный пояс) и ее северо-восточного обрамления (Верхояно-Колымская складчатая область), хотя линейность структур на востоке от платформы выражена не так эффектно, вместе с тем вся территория к востоку от р. Лена отличается также весьма высокими значениия ГАНЗ. Для центральных областей Сибирской платформы характерны невысокие, но в то же время и не нулевые значения активности.

К категории геодинамически активных зон принадлежит также, очевидно структуры так называемого шовного типа: шов краевой, шов структурный, шовная зона (Несмеянов, 2004). На исследуемой территории Восточной Сибири к таким структурным зонам приурочены как современные сильные землетрясения (рис. 4.2, 4.3), так и палеособытия (рис. 4.4). В 1951 г. в Кыллахском блоке Южного сектора Верхоянского складчато-надвигового пояса отмечено Сетте-Дабанское землетрясение с $\mathrm{M=6.5}$ (рис. 4.2). Его механизм очага выявил две субдолготные плоскости сместителя. По одной из них (северо-восточной) устанавливаются правые сдвиги, по другой (северо-западной) - левые. 


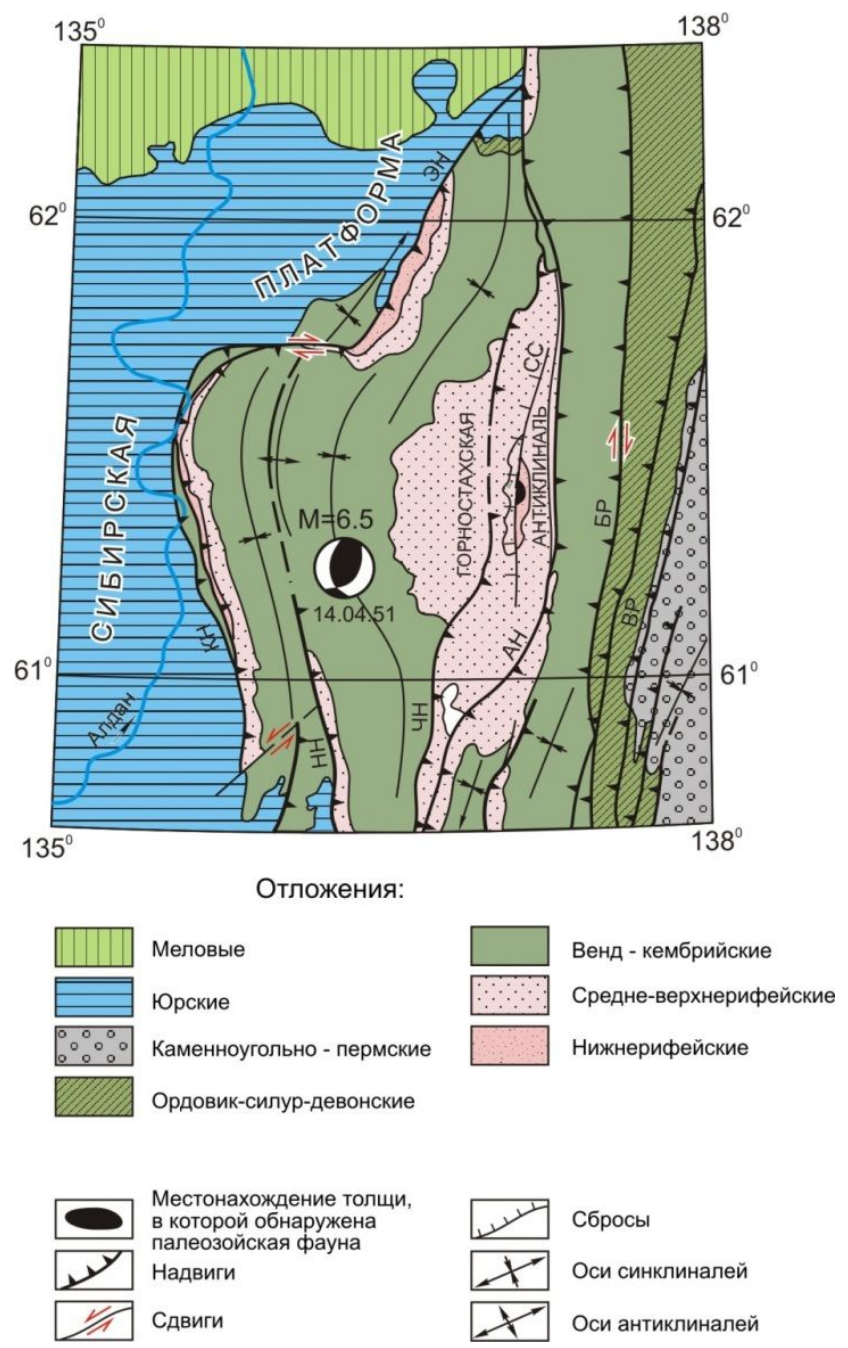

Рис. 4.2. Структурная схема Кыллахского блока центральной части Южно-Верхоянского сектора (по (Прокопьев, Дейкуненко, 2001) с добавлениями) Разломы: КН - Кыллахский надвиг, ЭН - Эбейке-Хаятинский надвиг, НН - Нельканский надвиг, ЧН - Чагдинский надвиг, АН - Акринский надвиг, БР - Бурхалинский разлом, ВР - Восточно-Сеттедабанский разлом, СС-Светлинский сброс

8 октября 1974 г. в восточной части в Березовском прогибе отмечено Средне-Ленское (Меличанское) землетрясение с $\mathrm{K}=13-14$ и $\mathrm{M=5.5-5.7} \mathrm{(рис.} \mathrm{4.3),} \mathrm{эпицентр} \mathrm{которого} \mathrm{располо-}$ жен в бассейне р. Бирюк, левого притока реки Лены (Козьмин, 1984). Его механизм (правый взбросо-сдвиг по субдолготной плоскости) полностью отражает стиль тектонических деформаций в зоне контакта (по Жуинскому разлому) структур Предпатомского прогиба и Алданской антеклизы, а также направленность сейсмотектонической активизации от структур Байкало-Патомского складчато-надвигового пояса к Сибирской платформе. 

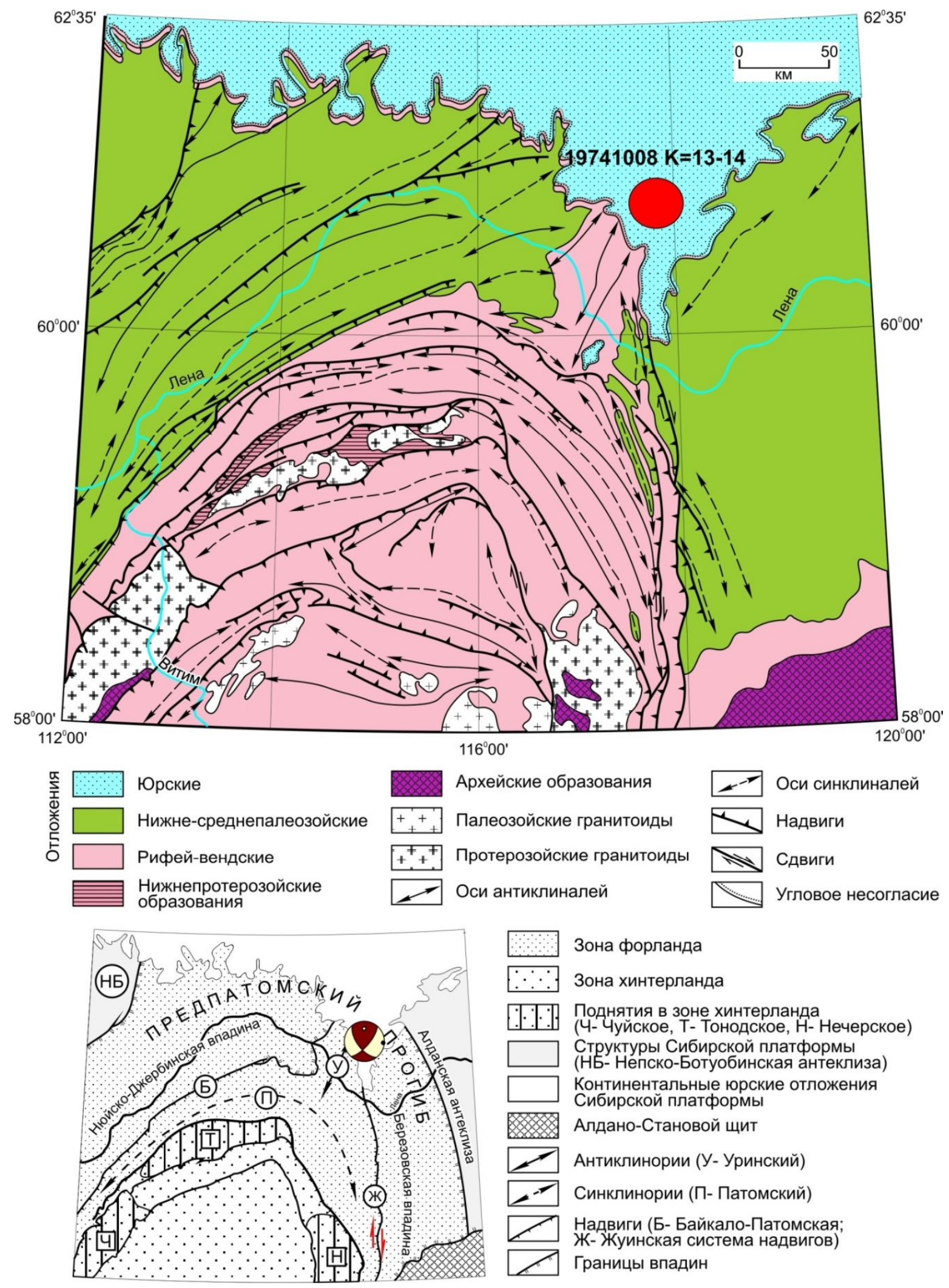

... П. Поднятия в зоне хинтерланда

Структуры Сибирской платформы

(НБ- Непско-Ботуобинская антеклиза)

Континентальные юрские отложения

Сибирской платформы

Алдано-Становой щит

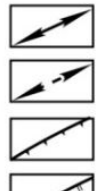

Антиклинории (У-Уринский)

Синклинории (П- Патомский)

Надвиги (Б- Байкало-Патомская; Ж-Жуинская система надвигов)'

Границы впадин

\section{Рис. 4.3. Структурная схема Байкало-Патомского складчато-надвигового пояса. Внизу показана схема тектонического районирования (по (Тектоника Якутии, 1975; Прокопьев, Дейкуненко, 2001) с дополнениями)}

Выявление на северо-западном фланге Главного Саянского разлома палеосейсмодислокаций, связанных с палеособытием с $\mathrm{M} \approx 8$ (Аржанникова и др., 2005), свидетельствует о зна- 
чительно большем сейсмическом потенциале этого сегмента данной шовной зоны. Ее потенциал видимо значительно больше, чем он был принят в комплекте карт ОСР-97 (M=6.5). Наиболее ярко сейсмодеформации проявлены в долине р. Кингаш (рис. 4.4).

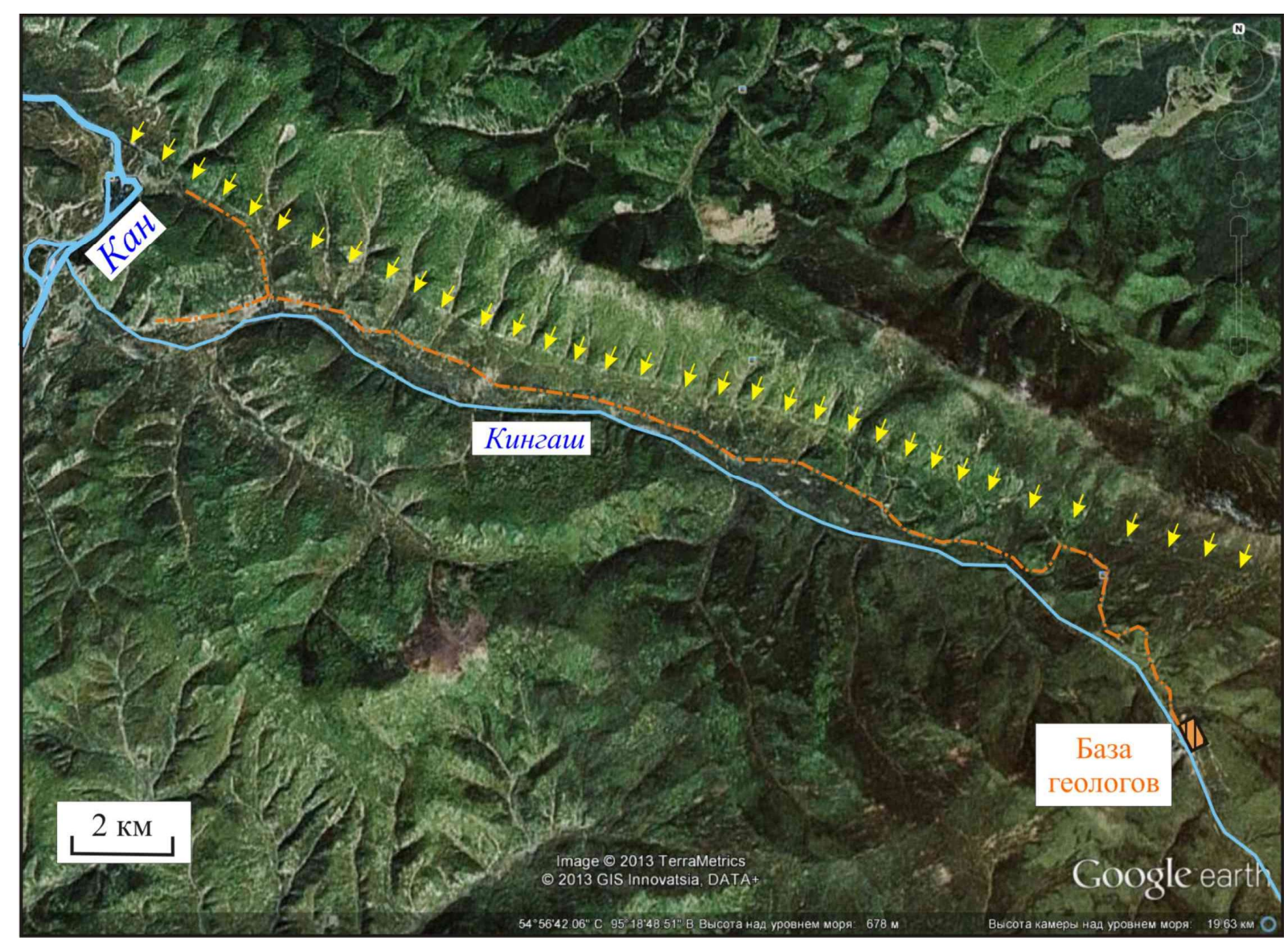

Рис. 4.4. Наиболее яркое проявление сейсмодеформаций Кингаш ПСД (почти непрерывная линия светлого тона, пересекающая многочисленные распадки) отмечена стрелками

Морфологический облик краевой шовной зоны приведен ниже (рис. 4.5). Различные проявления сейсмодеформаций в шовных зонах, по-видимому, связаны с разными геодинамическими режимами неотектонической жизни тектонических структур, на что обращали внимание многие российские предшественники. 


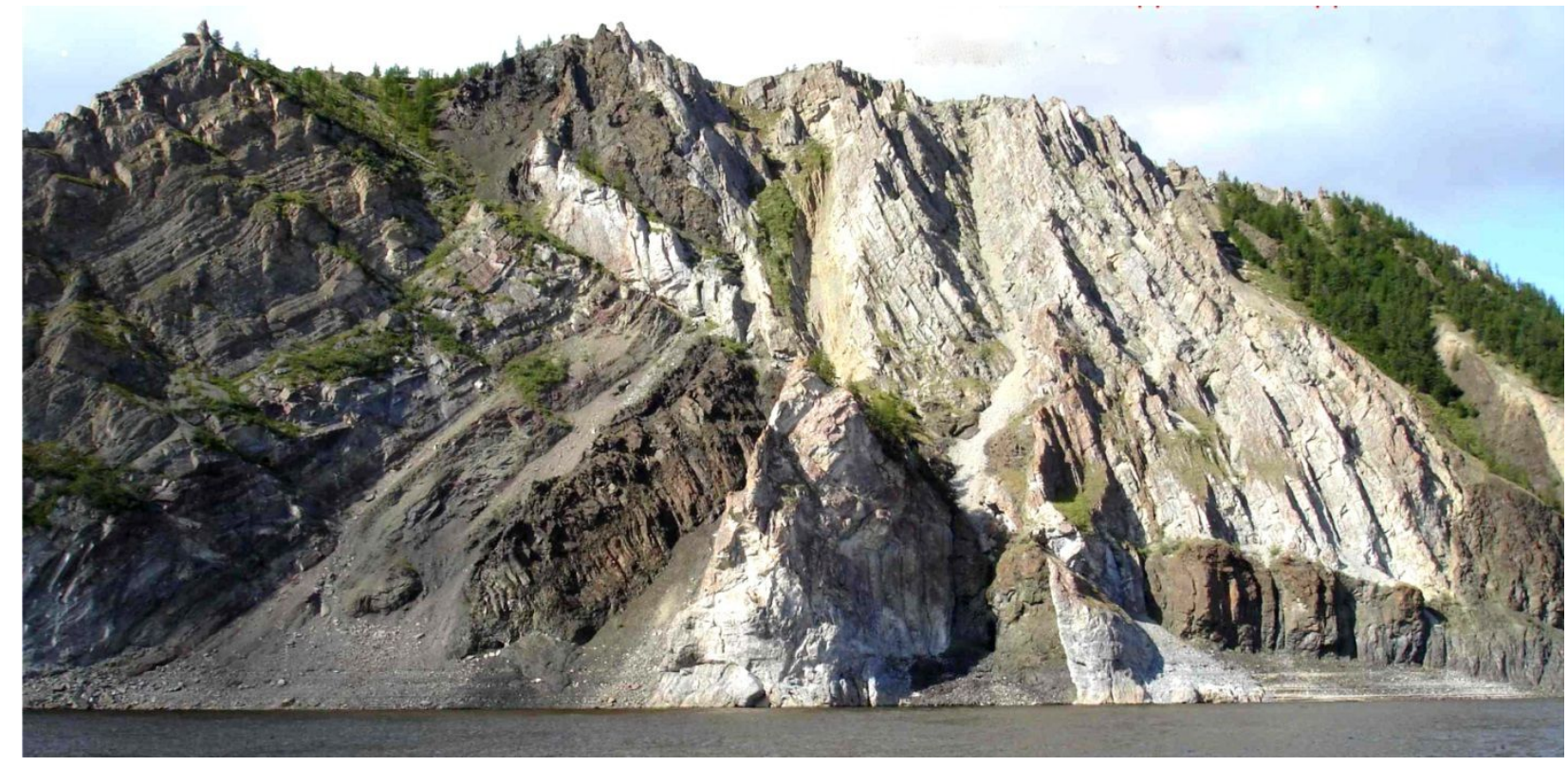

Рис. 4.5. Чекуровский надвиг, по которому отложения горно-складчатого Верхоянского комплекса надвинуты на отложения Сибирской платформы (фото А.В. Прокопьева)

Важнейшей составляющей сейсмотектонической модели являются прогнозные магнитуды землетрясений. Оценка максимально возможных магнитуд ожидаемых землетрясений производится по комплексу геолого-геофизических, сейсмологических и сейсмотектонических данных. График распределения магнитуд землетрясений, выполненный для разных зон неотектонически активных структур России, наглядно отображает высокую степень корреляционной зависимости $\mathrm{M}_{\text {мах }}$ от степени геодинамической активности неотектонических структур (рис. 4.6).

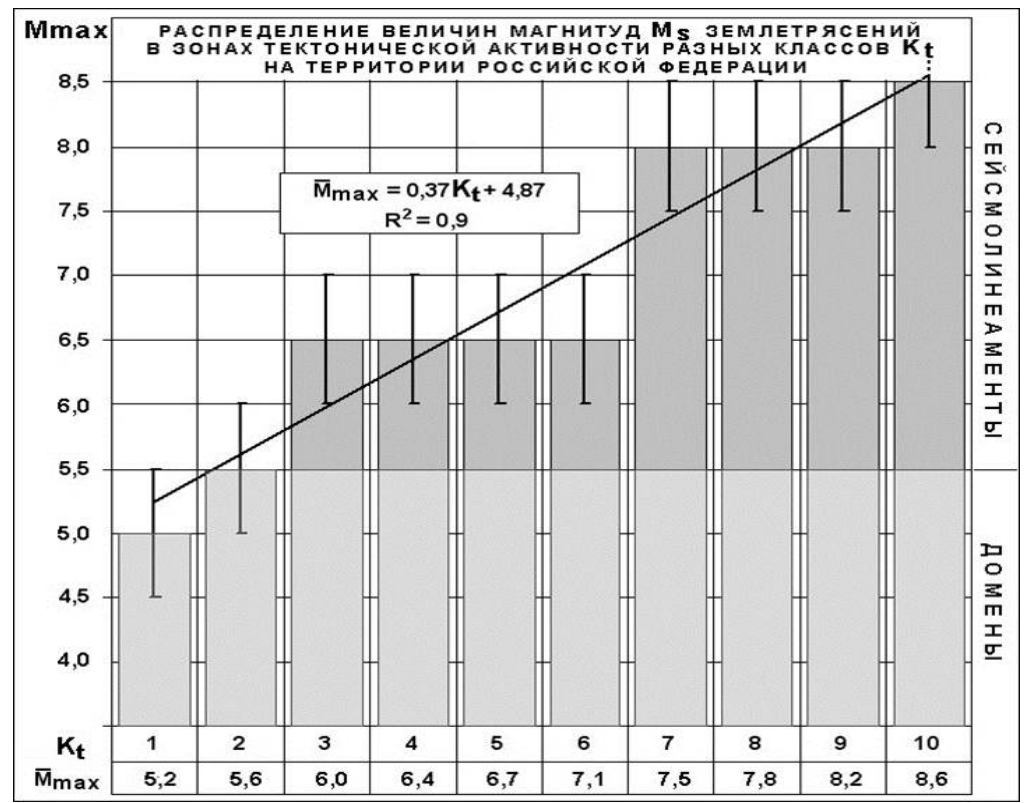

Рис. 4.6. Распределение магнитуд землетрясений в разных зонах неотектонически активных структур России (по (Уломов и др., 2011)) 
Как отмечалось раннее, выделение и параметризация, т.е. оценка сейсмического потенциала зон ВОЗ производится путем комплексного применения двух равноценных групп критериев: сейсмологической и геолого-геофизической. Приведенная карта планового распределения эпицентров землетрясений Восточной Сибири (рис. 4.7) была построена при компиляции данных, полученных региональными отделениями геофизической службы РАН и СО РАН, а также при использовании каталогов местных землетрясений, которые доступны по литературным источникам и свободно находятся в интернет-ресурсах на сайтах (Мackey et al., 2003; http:// www.seismos-u.ifz.ru/).

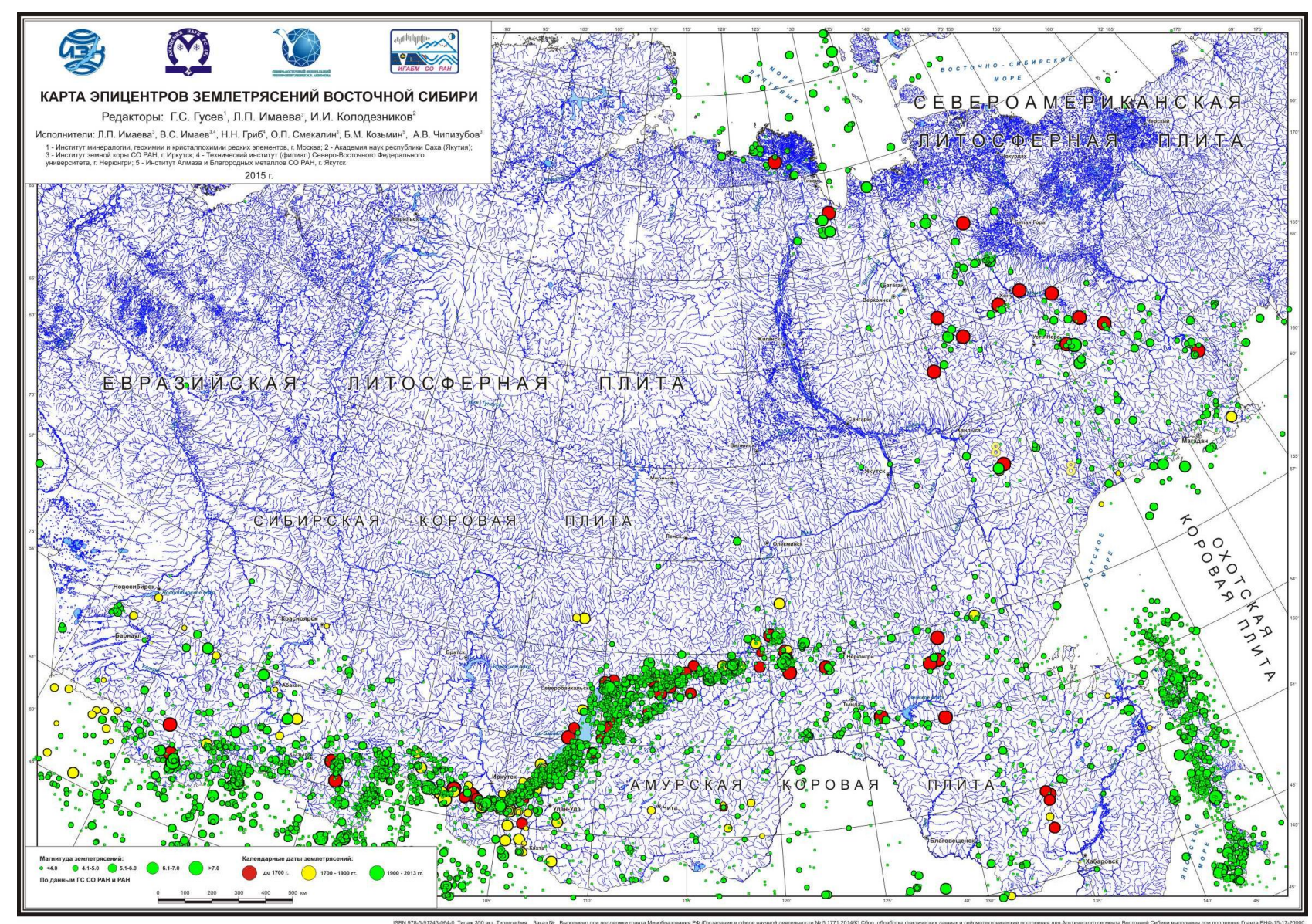

\section{Рис. 4.7. Карта эпицентров Восточной Сибири}

Составлена по компилячионным данным геофизической службы РАН и СО РАН, а также литературным данным и из интернет-ресуров (Mackey et al., 2010; http: // www.seismosu.ifz.ru).

Анализ планового распределения эпицентров землетрясений на территории исследований показывает на приуроченность Южно-Сибирского сейсмического пояса к южной границе Сибирской платформы в области развития горно-складчатых орогенных структур Алтая, Саян, Тувы. Далее, пространственно тяготея к области Байкальской рифтовой зоны, проявления сейсмичности образуют эпицентральные поля Олекмо-Становой области и соединяются с сейсмичностью побережья Охотского моря. Другой, Арктико-Азиатский сейсмический 
пояс, прослеживается от побережья моря Лаптевых и прослеживается через систему структур Верхояно-Колымской горно-складчатой области на юго-восток, соединяясь с сейсмичностью побережья Охотского моря и п-ва Камчатка.

Другим немаловажным фактором проявления сильных землетрясений определенных районов служит информация о механизмах очагов сильных землетрясений, сводный анализ которых, позволяет установить напряженно-деформированное состояние среды в тех или иных элементах геологической и неотектонической структур. Фокальные механизмы очагов землетрясений, произошедшие на территории Восточной Сибири приводятся на рис. 4.8. Факты приводимых решений механизмов очагов землетрясений, были скомпилированы из многочисленных работ разных авторов и интернет-ресурсов, находящихся в свободном доступе на соответствующих сайтах американской геологической службы (Мельникова, 2008; Радзиминович и др., 2004; Старовойт и др., 2003; Еманов и др., 2012; Козьмин, 1984; Имаева и др., 2010; Imaeva et al., 2015; http://earthquake.usgs.gov/earthquakes/).

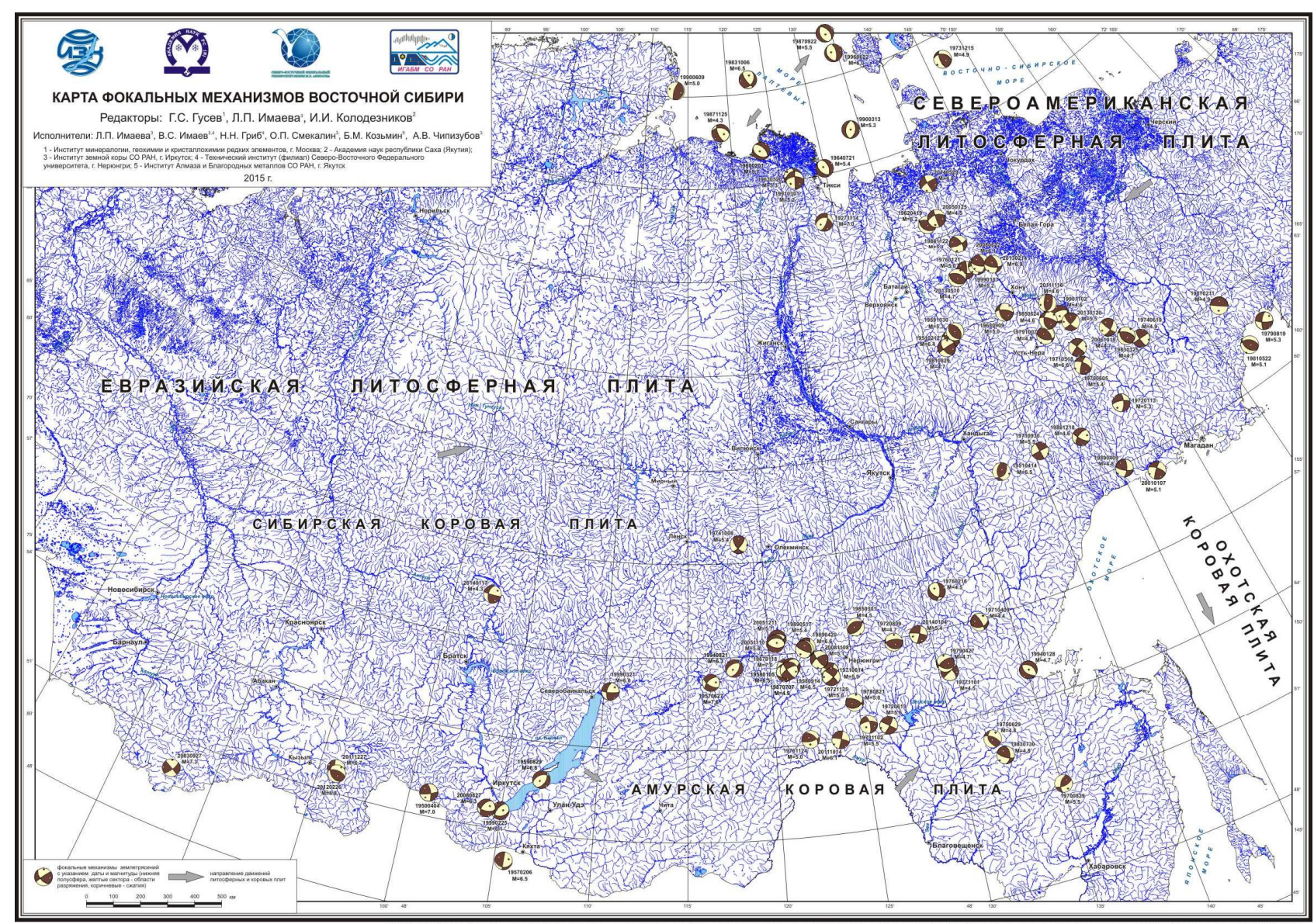

Рис. 4.8. Карта фокальных механизмов очагов землетрясений Восточной Сибири

Одним из главных выводов, следующих из рассмотрения планового распределения эпицентров землетрясений и решений фокальных механизмов их очагов, является то, что вся 
наблюдаемая современная сейсмичность и местоположение древних палеоземлетрясений группируются в протяженные сейсмические пояса, пространственно тяготеющие к южной и восточной границе Евразийской литосферной плиты. А тип напряженно-деформированного состояния земной коры указывает на превалирование процессов горизонтального сжатия вдоль всей континентальной части этой границы (за исключением Байкальской рифтовой области) и фрагментирование по геодинамическому принципу на отдельные сегменты Южно-Сибирского и Арктико-Азиатского сейсмических поясов.

Применение геолого-геофизической группы критериев зон ВОЗ в настоящее время состоит в выделении и параметризации активных геологических структур. Материалы детального изучения активных разломов и вторичных эффектов древних землетрясений, наряду с другими сейсмотектоническими и сейсмологическими данными, ложатся в основу карты зон возможных очагов землетрясений (ВО3). В результате проведенных многолетних исследований, все установленные активные разломы были вынесены нами на соответствующую топографическую основу территории Восточной Сибири с возможной установленной магнитудой генерируемых ими землетрясений (рис. 4.9).

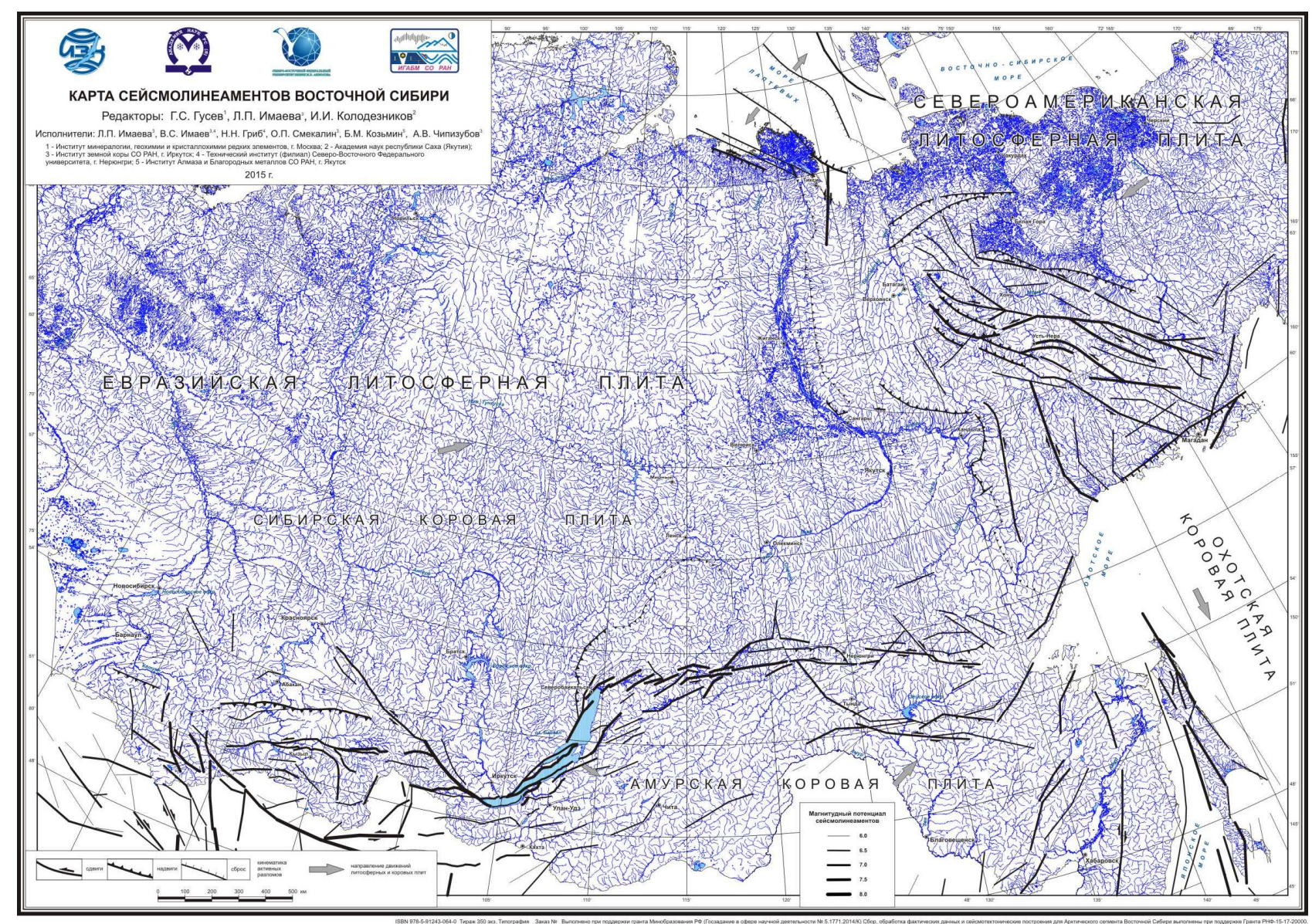

Рис. 4.9. Карта сейсмолинеаментов Восточной Сибири с предполагаемой магнитудой возможных землетрясений и установленной кинематикой смещения по активным разломам 
В конечном итоге весь собранный и проанализированный материал был обьединен в сводную карту сейсмотектоники, на которую была вынесены изолинии сейсмической активности в легенде ОСР-2014, которые сотвествуют карте В - с периодом повторяемости землетрясений в тысячу лет (рис. 4.10).

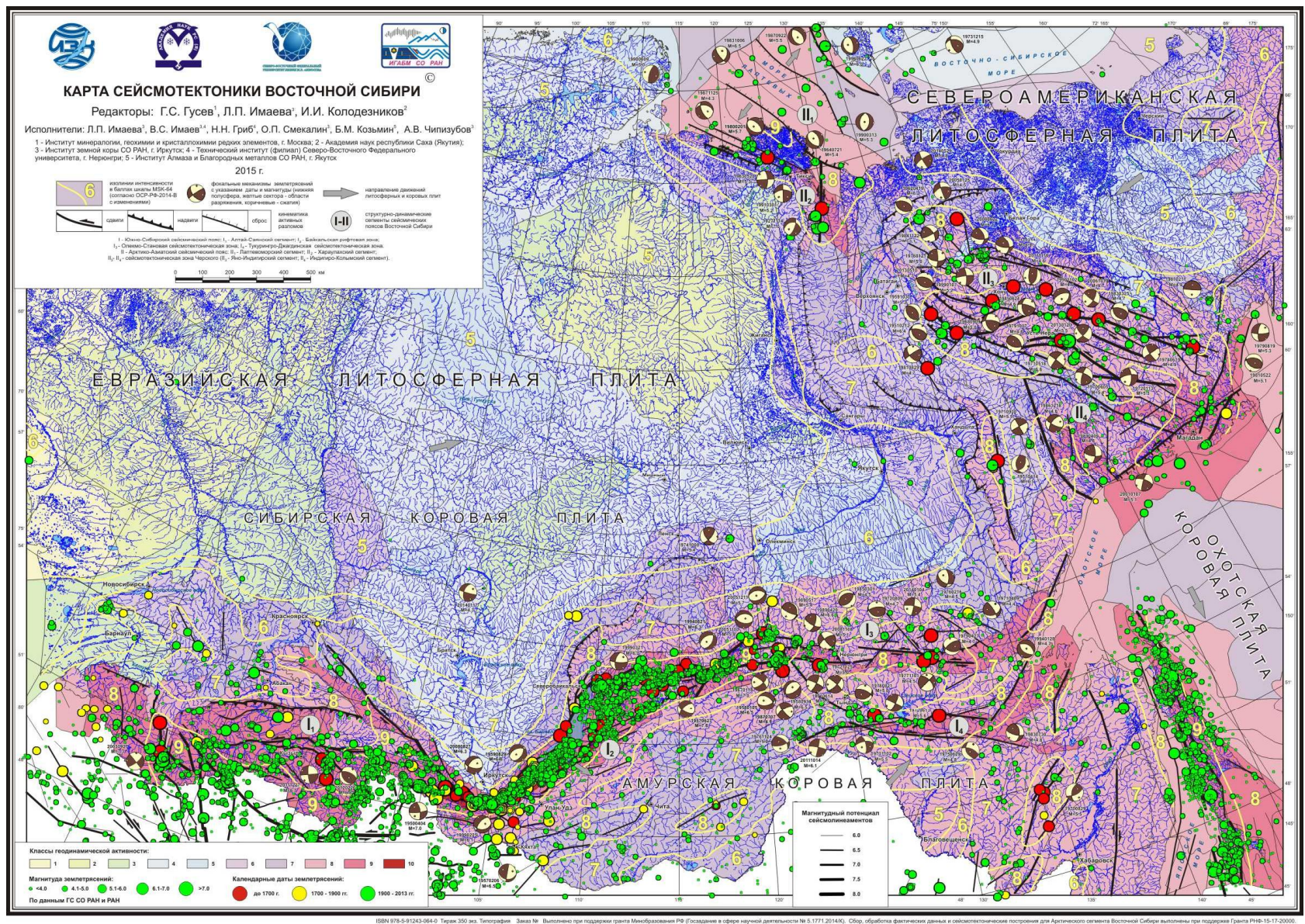

Рис. 4.10. Карта сейсмотектоники Восточной Сибири 


\section{ГЛАВА 5. СТРУКТУРНО-ДИНАМИЧЕСКИЕ МОДЕЛИ СЕЙСМОГЕНЕРИРУЮЩИХ СТРУКТУР ВОСТОЧНОЙ СИБИРИ}

Плановое распределение землетрясений в Восточной Сибири контролируется формированием Южно-Сибирского и Арктико-Азиатского сейсмических поясов, которые приурочены к границам крупных литосферных плит - Евразийской, Североамериканской, Китайской и Охотоморской (рис. 4.7). Южно-Сибирский сейсмический пояс прослеживаются в виде единой широкой полосы практически непрерывающейся сейсмичности широтного простирания вдоль южного края Сибирской платформы от западных отрогов Алтая на западе, через Саяны, Туву и систему Байкальских рифтовых впадин в центральной своей части, горную систему Станового хребта на востоке вплоть до побережья Охотского моря. (Имаева и др., 2012; 2013; 2014).

На северо-востоке Азиатского континента многолетними геолого-структурными и сейсмологическими наблюдениями выявлен гигантский Арктико-Азиатский сейсмический пояс (ААСП), соединяющий проявления сейсмичности в Северном Ледовитом и Тихом океанах (Зоненшайн, Савостин, 1979; Coook et al., 1986; Имаев и др., 2000). Ниже рассмотрим структурно-динамические модели отдельных, наиболее изученных, сегментов сейсмических поясов Восточной Сибири.

\section{1. ЮЖНО-СИБИРСКИЙ СЕЙСМИЧЕСКИЙ ПОЯС}

Землетрясения Южно-Сибирского сейсмического пояса формируют в пределах влияния южных границ Сибирского кратона единую протяженную Алтае-Саяно-БайкалоСтановую коллизионную зону, характеризующуюся определенными парагенезисами сейсмотектонических структур, контролирующих собой динамику очаговых зон крупных землетрясений. Детальное рассмотрение особенностей развития главных разрывных структур и формирование тесно связанных с ними морфоструктурных элементов позволили выделить в пределах единой структуры Южно-Сибирского сейсмического пояса отдельные сегменты: Алтай-Саянский, Тувинский, Байкальский и Становой сегменты.

Структурный рисунок активных разломов Алтая подчеркивает собой развитие территории как составной части единой Алтае-Саянской новейшей орогенной области, расположенной вдоль южной границы Сибирской платформы и включает в себя горные массивы Русского и Монгольского Алтая, достигающих максимальных величин поднятий 4.0-4.5 км. Активные разрывные структуры на Алтае образуют специфическую, ортогональную в плане разрывную структуру, развивающуюся в виде системы сближенных субпараллельных пра- 
вых сдвигов субдолготного (северо-западного) простирания развитых вдоль горных сооружений в Монгольском Алтае и веерообразно раскрывающихся к западу и северу на территории Русского Алтая в виде взбросов, надвигов и сдвигов.

Детальные исследования динамики процессов выделения сейсмической энергии в виде эпицентров землетрясений разных энергетических уровней (M=3.5-7.3), показывают, что основная масса сейсмической энергии, реализуемой в виде отдельных эпицентров землетрясений, пространственно тяготеют к горным сооружениям развитыми на территории Русского и Монгольского Алтая, объединяясь в общие сейсмические полосы, вытягивающиеся в субдолготном направлении и связанные с формируемой в современное время правобоковой транспресионной сдвиговой границы такого же простирания. Среди главных разрывов выделяются своей активностью Кобдинский, Шапшальский, Чарышско-Теректинский, КурайскоЧуйский правые сдвиги, а также надвиги субширотной ориентации - главный фас Алтая (Алейско-Саянский-Минусинский) (Рогожин, Платонова, 2002; Имаев и др., 2007).

Развитые восточнее активные разломы Саяно-Тувинской подвижной зоны представляют собой северо-восточные взбросы с преобладающей левосдвиговой составляющей. Это Саяно-Минусинский, Кандатский, Джебашский, Саяно-Тувинский и др. разломы. В Восточном Саяне большинство активных разломов сохраняет эту же ориентировку, но известны и северо-западные - например, Главный Саянский разлом - взброс с левосторонним сдвижением. Возможно, что в неотектоническом плане формирование северо-западных и северовосточных сейсмогенных структур (левых взбросо-сдвигов) связано с общим выдавливанием горных масс в направлении к северу на малоактивную часть Сибирской платформы по системе блоков-инденторов, ограниченных этими сдвигами.

Далее на восток граница Евразийской и Китайской плит выражена широтным фрагментом Байкало-Станового сейсмического пояса, который представляет собой широкую полосу эпицентров землетрясений (до 250-300 км), вытянутую вдоль южной окраины Сибирской платформы. Сейсмичность трассируется от оз. Байкал на западе в направлении к Удской губе Охотского моря на востоке. С начала века здесь отмечено свыше 30 тыс. землетрясений. Пояс включает в себя две части: Байкальскую рифтовую зону (БРЗ) на западе, охватывающую территорию Прибайкалья, и ее продолжение на восток Олекмо-Становую сейсмическую зону (ОС3), тяготеющую к Южной Якутии и Северному Приамурью (рис. 5.1). Названные части пояса существенно различаются между собой как по особенностям сейсмического режима, так и по геодинамическим условиям формирования структур земной коры. 


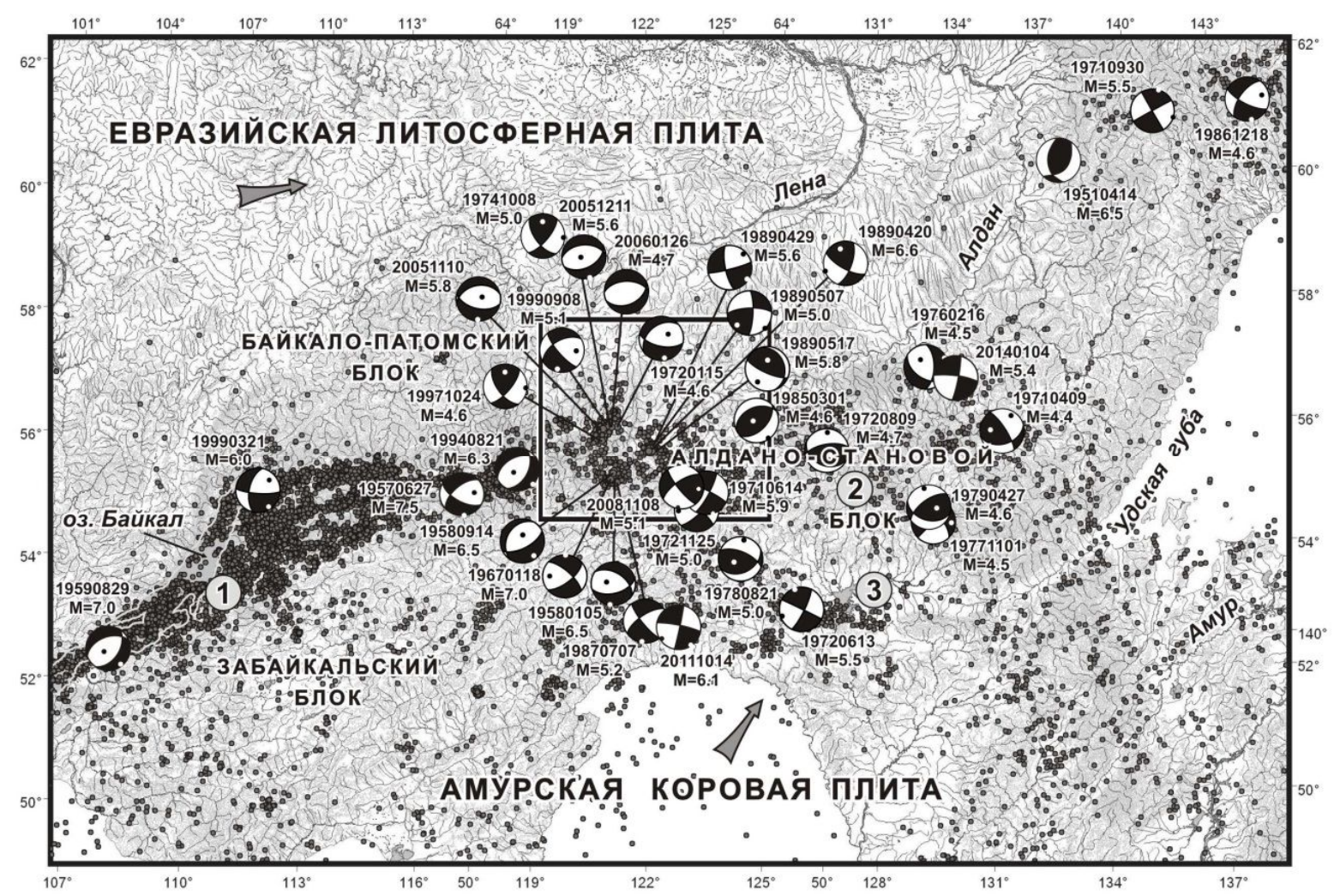

\section{Рис. 5.1. Сейсмические проявления в буферной зоне между Евразийской и Амурской литосферными плитами в течение $X X$ и начала XXI веков}

Рассматриваемая территория является областью контакта фронтальных сегментов Байкало-Витимского и Алдано-Станового супертеррейнов (Тектоника, геодинамика..., 2001), представляющих собой коллаж микроконтинентов с раннедокембрийской корой, причленение которых к Сибирскому кратону началось в протерозое и завершилось в позднем мезозое, когда прекратил свое существование Монголо-Охотский океанический бассейн. Рифейские, палеозойские и раннемезозойские офиолиты, комплексы активных и пассивных континентальных окраин отмечены в различных частях Монголо-Охотской сутуры, к северу от которой располагаются сооружения Байкало-Витимского и Алдано-Станового супертеррейнов, а к югу структуры Монголо-Охотского пояса.

В пределах Алдано-Станового супертеррейна широко распространены продукты мезозойской тектоно-магматической активизации, образующие несколько протяженных поясов, параллельных друг другу, которые накладывались на гетерогенный раннедокембрийский фундамент. Они выражены поясом гранодиоритовых батолитов Станового хребта, ЮжноАлданской системой впадин, выполненной мощными (до 5 км) угленосными толщами юры и неокома, субщелочными и щелочными вулканическими и интрузивными образованиями триасово-раннемелового возраста, широко распространенными на южной окраине Алданского щита. Эти зоны в совокупности соответствуют активной континентальной окраине мезо- 
зойского возраста (Имаев и др., 2000; Разломная тектоника..., 1976; Тектоника, геодинамика..., 2001).

Природа имеющих здесь место современных сейсмотектонических процессов связана с геодинамическими условиями, возникшими в пограничной зоне между Евразийской и Амурской литосферными плитами, сближение которых в восточном-северо-восточном направлении способствовало образованию в рельефе крупной зоны скучивания земной коры. Деформация и коробление земной коры в условиях сжатия привела к ее разделению на отдельные микроплиты и блоки, подновлению древних и образованию новых разрывных нарушений, которые их ограничивают. По существующим геотектоническим представлениям зона контакта Забайкальского и Алдано-Станового блоков тяготеет к бассейну р. Олекмы и представлена северо-восточным флангом Байкальской рифтовой системы, юго-западной частью Алданского щита Сибирской платформы, Становой складчатой областью, Монголо-Охотским складчатым поясом и его восточным Тукурингра-Джагдинским сектором.

Современные протяженные системы горных поднятий данного региона различного простирания, рассекаемые «живыми» разломами, начали формироваться в неогене после длительного периода пенепленизации в позднем мелу-палеогене (Имаев и др., 2000; Николаев и др., 1979; Николаев и др., 1982; Тектоника, геодинамика..., 2001). Их высокая сейсмотектоническая активность продолжается в настоящее время.

В кайнозойский структурно-вещественный комплекс здесь были объединены разрывные и морфоструктурные элементы в виде разломно-блоковых структур (РБС), которые сформировались на последнем этапе тектонической эволюции региона в обстановке рифтогенеза и дифференциальных субвертикальных и горизонтальных движений блоков, ограниченных зонами активизированных разломов.

Учитывая природу кайнозойских морфоструктурных элементов, степень контрастности тектонического рельефа и кинематический тип господствующих активных разломов, на исследуемой территории было выделено пять разломно-блоковых структур регионального плана, между которыми нет четкой границы: Чаро-Токкинская и Кодаро-Удоканская, охватывающие северо-восточное окончание Байкальской рифтовой зоны (БРЗ); Западно-Становая, тяготеющая к Олекмо-Становой зоне (ОС3) в пределах Становой орогенной области; Тукурингра-Джагдинская, как восточный фрагмент Монголо-Охотского складчатого пояса и, наконец, Темулякитская, разделяющая сейсмогенные структуры БРЗ и ОСЗ (рис. 5.2). При этом в Чаро-Токкинской и Кодаро-Удоканской РБС (Забайкальский блок) отмечается заметно меньшая по сравнению с Западно-Становой и Тукурингра-Джагдинской структурами (Алдано-Становой блок) степень унаследованности кайнозойской морфоструктуры от их докайнозойского структурного плана. Рифтовые впадины и разделяющие их дифференцированные 
новейшие сводово-блоковые поднятия в целом наложены и резко, часто вкрест простирания, «перерабатывают» древние структуры (Имаев и др., 2000; Тектоника, геодинамика..., 2001).

Наиболее мобильна система сопряженных диагональных сдвигов северо-восточного (Кодаро-Удоканская РБС) и северо-западного (Западно-Становая РБС) простирания, являющаяся главной сейсмогенерирующей структурой на западном фланге Алдано-Станового блока (рис. 5.1 и 5.2). Она включает большое число прямолинейных тектонических нарушений протяженностью в первые сотни километров, которые кулисообразно протягиваются сближенными субпараллельными группами, формируя на флангах морфотектонические структуры (миниблоки) сжатия или растяжения. При этом, более молодыми в Западно-Становой, Тукурингра-Джагдинской и Темулякитской РБС являются северо-западные, а в КодароУдоканской РБС - северо-восточные разломы, к которым приурочены основные поля локальных сгущений сейсмичности: Олдонгсинское (А), Олекминское (Б) и Южно-Якутское (B), где отмечены сильные землетрясения с магнитудами $\mathrm{M}=4.5-7.0$ и интенсивностью в эпицентре 6-9 баллов (шкала MSK-64) (Козьмин, 1984). К рассматриваемым разломам приурочены также зоны милонитизации, низкотемпературного диафтореза и брекчирования мощностью до нескольких сотен метров.

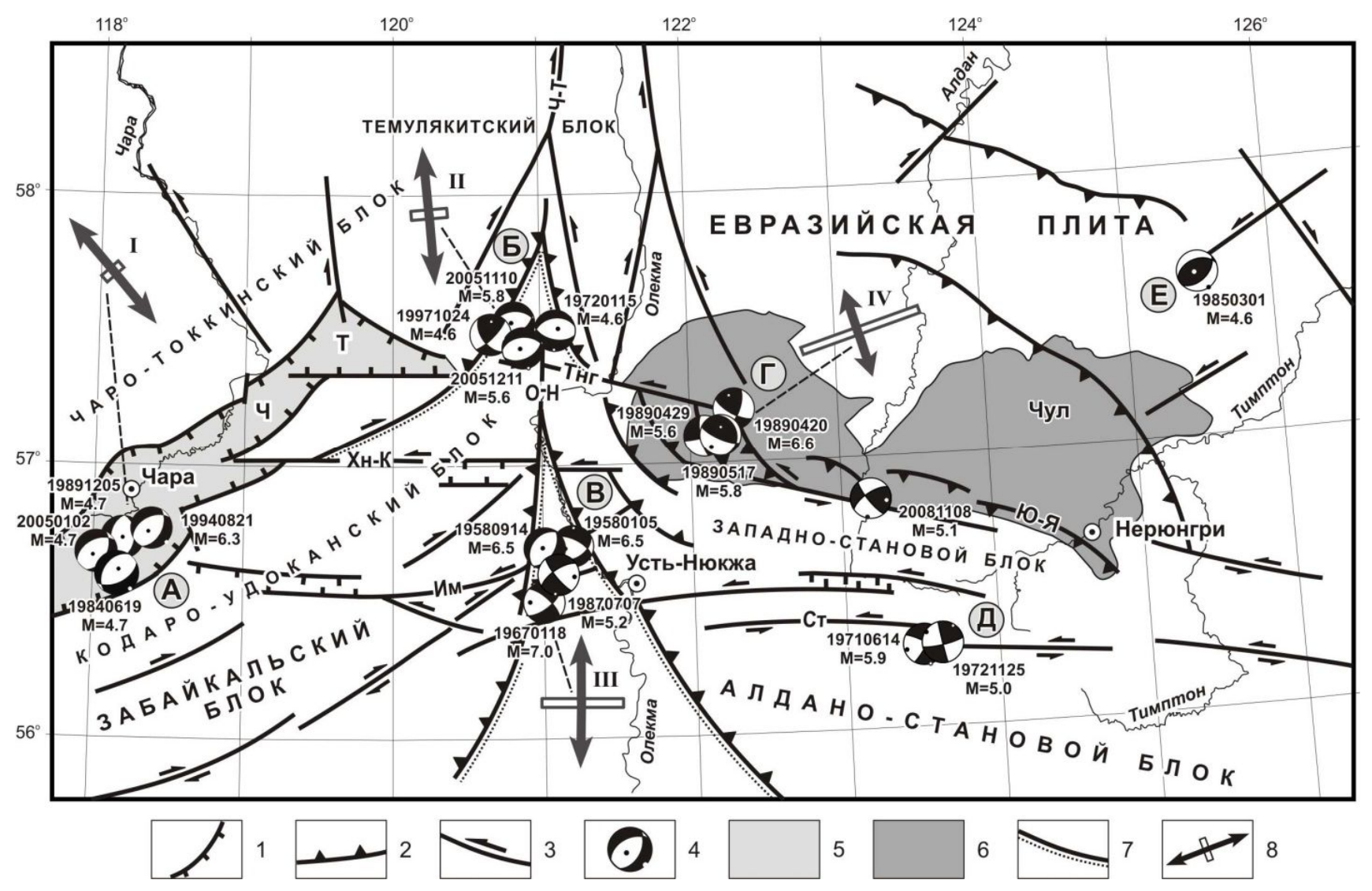

Рис. 5.2. Схема сейсмотектоники западного фланга Алдано-Станового блока 1 - сбросы; 2 - взбросы и надвиги; 3 - сдвиги (Хн-К-Хани-Кудулинский, Тнг - Тунгурчинский); 4 - направление и скорость современных движений плит и блоков в см/год (Бочаров, 
Замараев, 1991; Apel et al., 2006; Calais et al., 1998); 5 - круговые диаграммы фокальных механизмов сильных землетрясений (черная точка внутри диаграммы - положение оси сжатия, белая - оси растяжения), произошедших: 1 - 05.01.1958 г.; 2 - 14.08.1958 г.; 3 - 18.01.1967 г.; 4 - 14.06.1971 г.; 5 - 15.01.1972 г.; 6-25.11.1972 г.; 7 -01.03.1985 г.; 8-07.07.1987 г.; 9 20.04.1989 г.; 10 - 29.04.1989 г.; 11 - 17.05.1989 г.; 12 - 21.08.1994 г.; 13 - 24.10.1997 г.; 14 11.12.2005 г.; 15 - 10.12.2005 г.; 6 -кайнозойские впадины; 7 -мезозойские отложения Чульманской впадины. Эпищентральные поля: $A$ - Олдонгсинское; $Б$ - Олекминское; $B$ - Южноякутское; Г-Ларбинское; Д-Тимптонское; Е-Тимптонское

Центральной (осевой) структурой между Кодаро-Удоканской и Западно-Становой системами служит Темулякитская РБС (междуречье Чары и Олекмы). Она включает ряд параллельных и сочленяющихся под острым углом субмеридиональных дизьюнктивов, которые сформировали в ее пределах мозаику пластин, линз и блоков разной величины. Поскольку долготное простирание осевой зоны Темулякитского разлома является в данном районе доминантным, то оно подчиняет примыкающие с запада северо-восточные разрывы КодароУдоканской системы, а с востока - северо-западные и субширотные структуры ЗападноСтановой системы. Сейсмотектоническая позиция всей группы землетрясений, тяготеющей к данному району, определяется пространственным сопряжением Темулякитской РБС (осевая зона), Кодаро-Удоканской и Западно-Становой РБС по типу обратной Y-структуры. В соответствии с такой ориентировкой РБС по северо-восточным и северо-западным разломам должны фиксироваться сдвиги и сдвиго-взбросы, а между ними по разломам субширотного плана наблюдаться сбросовые смещения. Подобная обстановка действительно выявляется в бассейне среднего течения р. Олекмы, где по данным решения 4-х фокальных механизмов (1, 2, 3 и 8 на рис. 5.2) землетрясений, отмеченных в 1958-1987 гг., в их очагах действовали субдолготные горизонтальные напряжения растяжения и имели место сбросовые перемещения по субширотным плоскостям разрывов. Это также подтверждают выявленные палеосейсмодислокации в виде сейсморвов субширотного простирания Тас-Юряхской и ХаниКудулинской разломных зон, возникших после крупных подземных толчков в среднем течение р. Олекмы. Идентичная ситуация наблюдается сейчас в районе Олдонгсинского эпицентрального поля (А, рис. 5.2), где в 2005-2009 гг. был зарегистрирован крупный рой землетрясений с M=4.5-6.0 (6-8-баллов в эпицентральной зоне). Первоначально землетрясения роя происходили здесь в обстановке сжатия, но в дальнейшем сказалось влияние субдолготного растяжения, поэтому самые крупные события имели сбросовый фокальный механизм, а их эпицентры были приурочены к субширотным локальным зонам растяжения (Радзиминович и др., 2004).

Напряженное состояние земной коры Западно-Становой РБС обусловлено субгоризонтальным сжатием, ориентированным в северо-восточном направлении (фокальные механизмы 9-11, рис. 5.2). Вследствие этого, здесь и в центральной части Алданского щита разви- 
лась сеть молодых сдвигов северо-западного и северо-восточного простираний соответственно лево и право-сдвиговой кинематики, образующих X-образные пары. Сдвиговый характер перемещения по этим разломам подтверждается широко распространенными в обнажениях системами близвертикальных трещин с характерной горизонтальной штриховкой на их поверхностях, характером однотипного смещения геологических границ, параметрами фокальных механизмов тяготеющих к ним землетрясений: Южно-Якутское (В), Ларбинское (Г) и Тимптонское (Д) эпицентральные поля (рис. 5.2). Амплитуды латеральных смещений по указанным дизъюнктивам на геологических картах оцениваются величинами от нескольких сотен метров до нескольких километров. Они следятся к северу через Чульманскую впадину, отчетливо смещая ограничивающие её надвиги и взбросы, а также продолжаются на юг в пределы Становой области, где смещают мезозойские батолиты (Имаев и др., 2000). Продолжение этих разломов можно видеть в Монголо-Охотской складчатой системе и на северной окраине Буреинского массива. Формирование подобной системы диагональных разломов может быть связано с заключительными этапами коллизии Буреинского массива и Алдано-Станового блока (Тектоника, геодинамика..., 2001).

Данные закономерности в проявлении сейсмичности, характере полей тектонических напряжений и развитии определенных парагенезисов разломов, возникших в переходной зоне от БРЗ к ОСЗ, определили пространственную ориентацию разломно-блоковых структур, которые образовались при взаимодействии Байкало-Витимского (Забайкальского) и АлданоСтанового блоков. Первый, под влиянием байкальского поля тектонических напряжений (растяжения вкрест простирания структур) смещается на юго-восток относительно Сибирской платформы со скоростями 0.5-0.7 см/год (по данным GPS наблюдений) (Calais et al., 1998). Второй, зажатый между Евразийской, Амурской плитами и Забайкальским блоком, перемещается к востоку относительно Евразийской плиты с меньшей скоростью до 0.3-0.5 см/год (линейно-угловые геодезические измерения на Олекминском и Ларбинском геодинамических полигонах) (Бочаров, Замараев, 1991). В силу этого в бассейне р. Олекмы формируется система взбросов и надвигов противоположной вергентности к фронтальным структурам Забайкальского блока. 


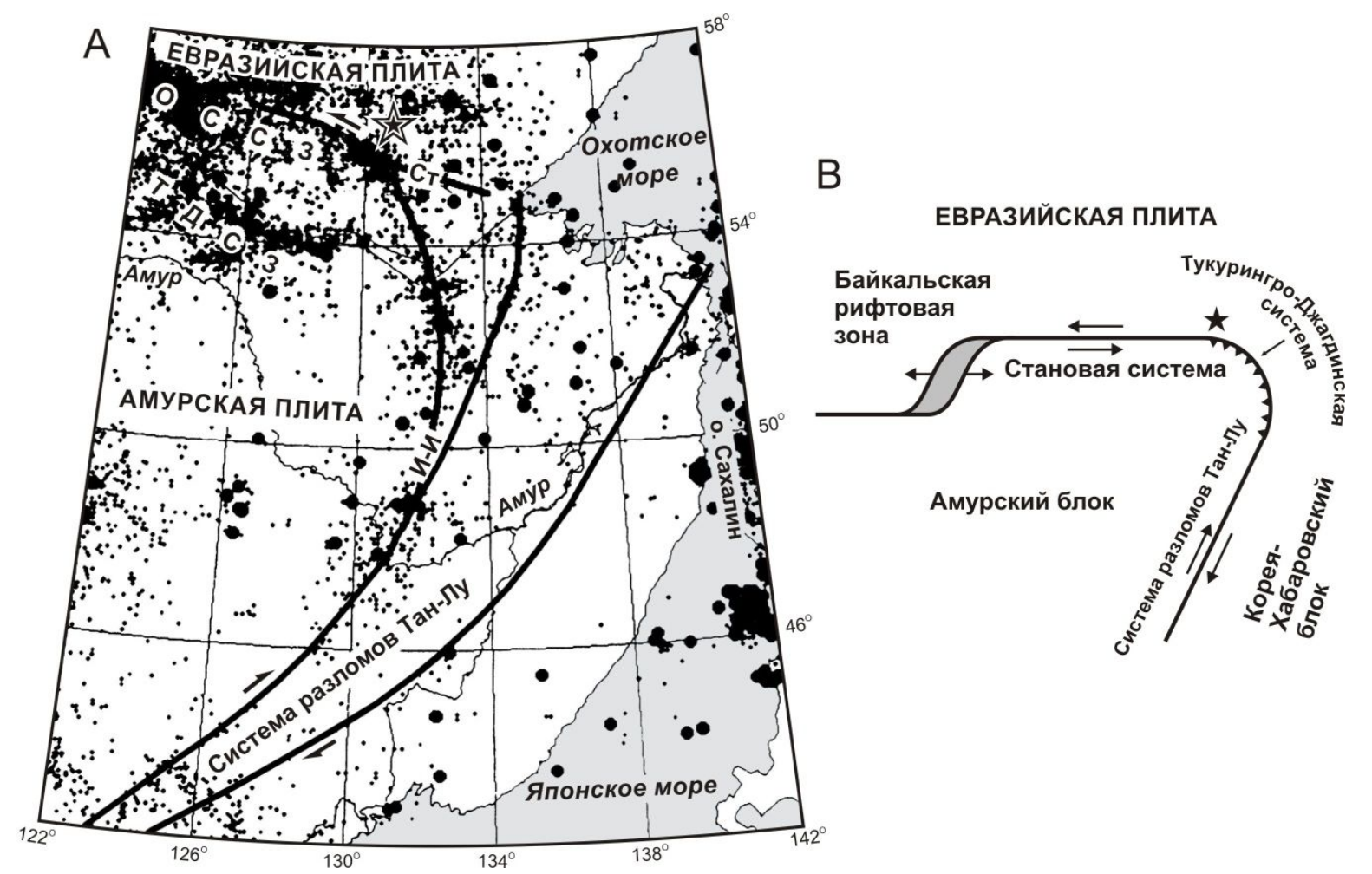

Рис. 5.3. Структура эпицентральных полей землетрясений и расположение основных структурных элементов в Южной Якутии и Приамурье (по (Mackey et al., 2003)) с дополнениями авторов

Сейсмотектонические зоны: ОССЗ - Олекмо-Становая, ТДСЗ - Тукурингра-Джагдинская. Разломы: Сm - Становой, И-И - Итун-Иланский. Звездочкой помечено кайнозойское поле вулканитов Токинского Становика

В пределах центральной части и восточного окончания Алдано-Станового блока по своей структурно-тектонической позиции выделяется ряд сейсмогенных структур, приуроченных к нескольким крупным геотектоническим зонам: на севере - Алдано-Учурской зоне поднятий, входящей в краевую активизированную часть Сибирской платформы, в центральной части - Становой складчатой области, а на юге - Предстановой денудационной ступени, орографически представленной Верхнезейской впадиной и Тукурингра-Джагдинской разломно-блоковой структурой восточного сегмента Монголо-Охотского складчатого пояса. Выявленные новейшие структуры рассматриваются в комплексе с ограничивающими их разрывными нарушениями и проявлениями местной сейсмичности. Приводятся также данные о мощности земной коры и особенностях распределения аномалий геофизических полей. На рис. 5.3 показаны восточные окончания Олекмо-Становой (восточный фланг БайкалоСтанового сейсмического пояса) и Тукурингро-Джагдинской зон (восточное окончание Монголо-Охотского линеамента) в виде сгущений эпицентров землетрясений, которые тяготеют к сейсмогенным структурам Алданского щита Сибирской платформы, Становой и МонголоОхотской орогенных областей, находящихся в зоне взаимодействия Евразийской и Амурской плит. При этом наиболее отчетливо следятся зоны влияния краевых швов или сутур 
(Становой, Тукурингра-Джагдинский и др.). Названные разломы выделялись по их значительной (> 100 км) протяженности, влиянию на процессы кайнозойского осадконакопления, разграничению ими крупных блоков земной коры, уверенному дешифрированию на аэрофото и космоснимках, приспособленностью к их трассам местной гидросети, приуроченностью к ним эпицентров землетрясений, смещению ими террасовых уровней, наличию в их зонах влияния древних и современных сейсмодислокаций и др. Разломы низших порядков различались по их небольшой длине, они чаще соответствовали ответвлениям от главного разрыва, а также разграничивали крупные морфоструктуры на составные части. Таким является Итун-Иланский разлом, выделенный в поле сейсмичности и пересекающий шовные зоны Становой и Тукурингра-Джагдинской сутур (рис. 5.4).

В пределах данной территории можно выделить три крупных геоблока: ЦентральноАлданский (I), Восточно-Алданский (II) и Тукурингра-Джагдинский (III). На их наличие указывают, например, отдельные элементы глубинного строения, отраженные в изолиниях на схемах мощности земной коры (км), где граница Мохоровичича в областях морфологически выраженных поднятий, как правило, имеет тенденцию к погружению, а в областях развития отрицательных структур - к подъему (Суворов, Корнилова, 1985; Тектоника, геодинамика..., 2001). Так, в пределах Центрально-Алданского блока толщина земной коры может достигать 48-60 км. При этом в зоне умеренных неотектонических поднятий (Гонамский и УчуроИдюмский блоки) залегание границы Мохоровичича фиксируется на глубине 38-40 км, а к югу в зоне интенсивных сводово-блоковых движений (Токинский Становик) происходит ее погружение до 52 км. Идентичная толщина земной коры характерна и для ВосточноАлданского геоблока (44-48 км). Крупные геоблоки подразделяются по их различной направленности, интенсивности и контрастности неотектонических движений (Имаев и др., 2000) существующей сетью активных разломов на систему более мелких структур. В составе крупного Центрально-Алданского геоблока наиболее значимы новейшие блоки: Токинского Становика (1), Сутамский (2), Гонамский (3), Учуро-Идюмский (4) и др. 


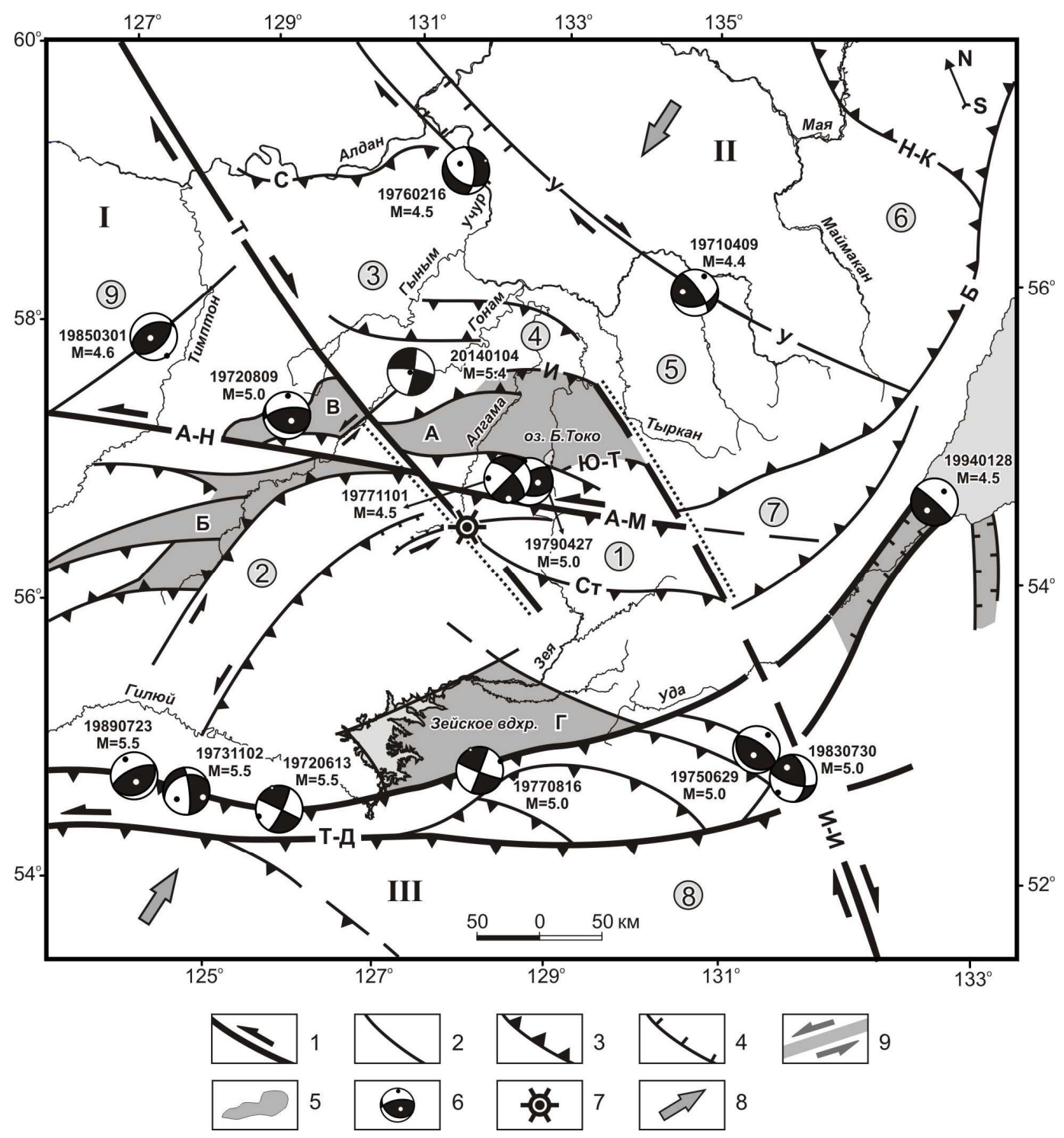

Рис. 5.4. Схема разломно-блоковых структур центральной и восточной частей Алдано-Станового блока

1 - главные сейсмогенерируюшие структуры сдвиговой кинематики; 2 - разломы неизвестной кинематики; 3 - надвиги; 4 - сбросы; 5 -мезозойско-кайнозойские впадины ( $а$ - Токинская, б - Атугей-Нуямская и Гонамские, в - Ытылмджинская, г-Верхнезейская и Удская); 6 - диаграммы фокальных механизмов землетрясений (черная точка внутри диаграммы - положение оси сжатия, белая - оси растяжения), рядом проставлена дата возникновения землетрясения; 7 - кайнозойское поле базальтов; 8 - направление действия регионального поля тектонических напряжений. Римскими ициррами обозначены крупные геоблоки: I - Центрально-Алданский, II - Восточно-Алданский, III -Тукурингра-Джсагдинский. Арабскими иифрами в кружках помечены новейшие блоки (структуры): 1 - Токинский Становик, 2 - Сутамский, 3 -Гонамский, 4 - Учуро-Идюмский, 5 - Тырканский, 6-Батомгский, 7 - Джугжурский, 8 Баджальский, 9 -Тимптонский. Буквенные обозначения: главные разломы (A-H - AтутейНуямский, А-М - Авгенкуро-Майский, Т - Тыркандинский, У - Улканский, И-И - ИтунИланский, Т-Д - Тукурингра-Джагдинский), краевые швы (Б - Беликчанский, Н-К - НельканоКыллахский, Сm - Становой) и другие разрывные нарушения (Ю-Т - Южно-Токинский, ИИдюмский, С-Суннагинский)

Самое высоко поднятое (2100-2300 м абсолютной высоты) складчатое сооружение Токинского Становика представляет собой интенсивно развивающийся неотектонический блок, 
сложенный преимущественно архейскими породами. С севера он оконтурен четко выраженной в рельефе линией Южно-Токинского надвига с амплитудой вертикальных тектонических движений 1000-1200 м. Центральная часть блока раздроблена серией разломов преимущественно субширотного и северо-западного простираний. Наиболее значительный из них - Авгенкуро-Майский сдвиго-взброс длиной около 400 км. Разлом вытянут от р. Алгама на западе предположительно до Удской губы Охотского моря на востоке. Он отчетливо дешифрируется на космических снимках в виде непрерывной линии запад-северо-западной ориентации. Это направление выдерживается на большей части его трассы, пересекая водоразделы и подчиняя себе элементы гидросети разобщенных бассейнов рек Лены и Амура. На водоразделах нарушение фиксируется в виде борозд, ложбин и полос. В бассейне верхнего течения p. Алгама упомянутый линеамент соединяется диагональной (северо-западного направления) перемычкой с Атугей-Нуямским разломом. Вблизи перемычки в южной части Токинского Становика выявлено поле (площадью 200 кв. км) оливиновых базальтов, где имеется около 20 вулканов «центрального типа». Авгенкуро-Майский дизъюнктив сейсмоактивен на всем протяжении. Прямолинейность его трассы, почти крутое залегание плоскости сместителя, общий структурный рисунок и параметры фокальных механизмов землетрясений 01.11.1977 г. и 27.04.1979 г., отмеченных в его зоне влияния (рис. 5.4), позволяет определить тип кинематики разлома как сдвиго-взброс (надвиг). Отчетливо выраженный скарп с падением плоскости разрыва на юг в направлении Верхнезейской впадины, обнаруженный во время полевых работ вдоль северного склона одного из хребтов Токинского Становика вблизи Авгенкуро-Майского разлома, однозначно указывает на высокую тектоническую и сейсмическую активность последнего.

Интенсивные дифференцированные восходящие движения Токинского Становика обусловили резкую расчлененность его рельефа (относительные превышения до 1200-1300 м) и крутизну склонов. Вследствие этого здесь развиты преимущественно гравитационные процессы, повсеместно распространены мощные грубообломочные делювиальные и делювиально-пролювиальные шлейфы и конуса выноса, часты проявления обвалов. Некоторые из них имеют сейсмогенный характер (верховья р. Сам-Анкикит и долина р. Б. Туксани) (Имаев и др., 2000; Николаев и др., 1982).

Авгенкуро-Майский разлом с амплитудой вертикального перемещения 500-700 м делит Токинскую морфоструктурную область на два района - Северный и Южный. Северный район Токинской морфоструктуры - высокогорный массив (абсолютная высота до 2300 м) с альпинотипным рельефом, выработанным в эпоху последнего (позднечетвертичного) оледенения. Район с юга и севера оконтурен линиями крупных разрывных нарушений (АгенкуроМайский и Южно-Токинский). В нем регистрируется повышенный уровень сейсмической 
активности (землетрясения с $M=2.5-6.5)$ и выявлен ряд сейсмодислокаций (Имаев и др., 2000; Козьмин, 1984). К названному району тяготеет значительная положительная аномалия в поле силы тяжести. Его современная активность подтверждается также высоким тепловым потоком, измеренным вблизи оз. Большое Токо, со значениями до 80 мвт/м². Здесь же фиксируется широкое проявление наледных процессов (Имаев и др., 2000).

Южный район Токинской морфоструктурной области имеет низко-среднегорный слабо расчлененный рельеф со средними абсолютными высотами 1500-1700 м. Уровень сейсмичности здесь меньше, чем в Северном районе. Магнитуды отмеченных землетрясений - 2.55.0. Эпицентры слабых подземных толчков равномерно заполняют всю территорию района с небольшой их концентрацией вблизи его северной границы. Южной границей этого района служит Становой разлом, который в виде дугообразной зоны шириной 8-10 км прослеживается по участкам рассланцевания и диафтореза в архейских и протерозойских породах (рис. 5.4). Разлом обладает здесь умеренной сейсмической активностью, а магнитуда местных землетрясений не превышает 4.5 .

Сутамский блок (2) расположен на западе региона и отделяется от Токинского Становика субмеридиональным отрезком р. Алгамы. Его северная граница отвечает АтугейНуямскому разлому, южная - фиксируется эрозионно-тектоническим уступом высотой 30 60 м, обрывающимся к Верхнезейской впадине. В пределах Сутамского блока находятся ряд мезозойско-кайнозойских впадин (Атугей-Нуямская, Гонамские) (б, рис. 5.4). Так, узкая субширотная Атугей-Нуямская впадина (100x8 км) сочленяется с горным обрамлением по ступенчатому эрозионно-тектоническому уступу высотой 300-400 м. По северному борту депрессии, выполненной среднеюрскими угленосными отложениями, фиксируется близширотный Атугей-Нуямский разлом длиной до 250 км, представленный зоной повышенной трещиноватости и брекчированности мезозойских песчаников. Вдоль разлома на поверхности тектонических трещин часто встречаются зеркала скольжения, указывающие на преобладающие сдвиговые перемещения. На космоснимках разлом выражен контрастной полосой фототона, отвечающей резкому уступу в рельефе. В геофизических полях Атугей-Нуямский дизъюнктив представлен резкой градиентной ступенью (Имаев и др., 2000). Южным ограничением Атугей-Нуямской, а также Гонамских и Ытымджинской впадин (в) являются надвиги. Такая кинематика поддерживается данными распределения отрицательных гравитационных аномалий. Они в виде протяженных линейных зон повышенных градиентов (гравитационных уступов) локализованы примерно параллельно разломам, трассируемым вдоль южных бортов перечисленных впадин, но смещены от них к югу на расстояния от нескольких до 1015 км. Это может свидетельствовать о надвиговой природе этих разрывных нарушений. Подвижки такого же типа (надвиг-взброс) имели место также при землетрясении 09.08.1972 г. на 
южной окраине Ытымджинской депрессии. Рельеф Сутамского блока - среднегорный с абсолютными высотами 1500-2000 м, глубина расчленения достигает здесь 800-1000 м. В его центральной части фиксируются отдельные кулисы Станового разлома, к зоне влияния которого приурочены эпицентры редких землетрясений с $\mathrm{M}=3.5-4.5$. Все это указывает на более низкий темп сейсмотектонических движений в Сутамском блоке по сравнению с блоком Токинского Становика.

Гонамский блок (3) тяготеет к юго-восточной части Алданского щита (рис. 5.4). Он представляет собой горст, преимущественно архейских кристаллических пород, осложняющий южное крыло Гонамского сводового поднятия. В рельефе блок выражен сложной ветвящейся системой горных хребтов альпинотипного облика (Нингамского, Ытымджинского, Сутамо-Гонамского), характеризующихся глубоким (до 1000 м абсолютной высоты) расчленением, узкими гребневидными водоразделами, крутыми склонами, покрытыми сплошными осыпями. В плане Гонамская морфоструктура представляет собой куполовидное поднятие, рассечённое крупным Тыркандинским разломом северо-западного простирания, на две неотектонические ступени высотой соответственно 1500-1700 м и 1700-2300 м. Тыркандинский глубинный разлом трассируется на расстояние 600 км от устья р. Тимптон до среднего течения р. Алгамы, где образует разломный узел с Южно-Токинским, Атугей-Нуямским и Авгенкуро-Майским дизъюнктивами.

Зона влияния упомянутого разрыва представляет собой ряд кулис, пространственное расположение которых указывает на возможные подвижки вдоль разлома по типу правого сдвига. Он контролируют местоположение нижнепротерозойских трогов и мезозойских грабенов, а также гранитоидов и основных интрузий архейского, протерозойского и мезозойского возраста. Тыркандинский разлом отчетливо диагностируется по цепочкам линейных магнитных аномалий, а в поле силы тяжести распознается по резкой градиентной ступени (Разломная тектоника..., 1976). К трассе этого дизъюнктива приурочены эпицентры землетрясений с M=2.5-4.5. В устье р. Сутам, в месте предполагаемого пересечения Тыркандинским разломом р. Гонам, наблюдается резкий изгиб русла реки и выходы в ней коренных пород. На правом борту долины р. Гонам выявлены площадные сейсмогравитационные срывы делювиального материала.

Учуро-Идюмский блок (4) включает в себя небольшие сводовые поднятия фундамента по северной окраине Токинской впадины (Арбарастахское, Идюмо-Хайканское), образующие цепь возвышенностей, обрывающихся к югу тектоническим уступом высотой 300-400 м. В центре Учуро-Идюмского блока на поверхность выходят породы фундамента, поднятые до высоты 1700-1800 м. Реки Идюм и Алгама пересекают эти поднятия, врезаясь на глубину до 100 м, и образуют узкие неразработанные, крутосклонные долины с врезанными меанд- 
рами. Водоразделы здесь узкие, скалистые, гребневидные, реже широкие плоские, со структурными уступами на склонах. Подобный рельеф характерен и для восточной части блока. Следы новейшей и современной активизации особенно ярко проявились по южной границе данного блока с Токинской впадиной в районе Идюмского надвига. Субширотный Идюмский надвиг (200-250 км длиной) отделяет Учуро-Идюмский блок от мезозойских отложений Токинской впадины. Он представляет собой серию крутых надвигов (до 45-50) с падением плоскостей разломов как северной, так и южной вергентности. В обнажениях по р. Алгаме плоскость этого разрывного нарушения четко фиксируется зоной повышенной раздробленности и трещиноватости юрских песчаников, соприкасающихся с протерозойскими известняками. По многочисленным зеркалам скольжения повсеместно устанавливаются взбросовые и надвиговые подвижки.

Разлом отчетливо выделяется по геофизическим материалам полосой линейновытянутых аномалий, окаймляющих фоновые значения гравитационного и магнитного полей. На относительную тектоническую активность этого разлома в кайнозойское время указывают его отчетливая выраженность, наличие эрозионных ложбин в основании плоскости разлома, многочисленные фасеты на фронтальной плоскости, осыпи и курумы. Разлом сейсмически активен. Ежегодно в его зоне влияния регистрируется несколько слабых землетрясений $(\mathrm{M} \leq 3.0)$, хотя также имеют место одиночные сильные события, как, например, землетрясение 3.02.1999 г. с М=4.5, сопровождаемое серией афтершоков (около 40 событий). По результатам структурных исследований, проведенных по рекам Алгама и Идюм в зоне Идюмского надвига, в этой части Учуро-Идюмского хребта были выявлены молодые формы рельефа (уступы, повышенная дислоцированность пород вблизи разломов, образование небольших складок и др.), а также проявления сейсмогравитационных процессов.

Тырканский блок (5) выделен на востоке исследуемой территории. В структурном отношении он представляет собой Идюмо-Хайканский выступ кристаллического фундамента. Его рельеф выражен несколькими крупными среднегорными массивами, сложенными архейскими породами с абсолютными высотами 1600-1900 м. Они ориентированы в северозападном и субширотном направлениях (восточная часть Учуро-Идюмского хребта). Лишь в средней части морфоструктуры встречаются небольшие «пятна» юры. Юго-восточная окраина района имеет пониженные высоты преимущественно до 1100 м и сравнительно плоскогорный рельеф. Западной границей блока является Итун-Иланский (по другим авторам Юлан-Ютонгский) разлом (Huang et al., 1996; Mackey et al., 2003), сопровождаемый «облаком» эпицентров землетрясений в Приамурье (рис. 5.1 и 5.3). Структурно он представляет западную ветвь системы разрывных нарушений Тан-Лу с правосдвиговой компонентой смещения, продолжающуюся из Северного Китая на территорию России. 
Вблизи пересечения Итун-Иланского разлома с Тукурингра-Джагдинской разломной системой он характеризуется взбросо-надвиговым смещением (параметры фокальных механизмов землетрясений 29.06.1975 г. и 30.07 .1983 (г, рис. 5.4), образуя с ней дуплексную зону сжатия. Далее, отдельными кулисами, Итун-Иланский разлом следится в северо-западном направлении и, рассекая структуры Станового свода, контролирует восточные окраины Токинской впадины. В пределах Тырканского блока фиксируется повышенный уровень сейсмической активности. Здесь зарегистрирован ряд землетрясений с $\mathrm{M}=2.5-5.0$, тяготеющих к зонам влияния Итун-Илонского и Улканского разломов.

Токинская впадина (a) - мезокайнозойский прогиб, ограниченный крупными дизъюнктивными нарушениями большой амплитуды, выраженными в рельефе тектоническими уступами. Южная граница соответствует зоне Южно-Токинского надвига (амплитуда вертикальных тектонических смещений до 1200 м), северная - проходит по Идюмскому взбросу (амплитуда 300-400 м). Субширотный Южно-Токинский надвиг длиной более 200 км является одним из крупных разрывных нарушений региона. Он характеризуется крутыми углами падения плоскости сместителя (60-70). Его горизонтальная амплитуда надвигания архейских кристаллических образований на мезозойские толщи впадины составляет первые километры. При этом сопряженные с надвигом юрские и нижнемеловые отложения южной окраины Токинской впадины интенсивно дислоцированы в полосе шириной до 5-7 км. На местности разлом выражен резким тектоническим уступом. Рельеф впадины сформирован на песчаносланцевых отложениях юры и нижнего мела со слабым (3-5) наклоном к центру (Имаев и др., 2000; Николаев и др., 1982), что обусловило развитие его платообразной формы, слабую выраженность структурных форм, пологость склонов и плавность сочленений. Поверхности водоразделов здесь плоские и пологоувалистые, имеющие высоты в центральной части 9501100 м, а по окраинам - до 1200 м. Поверхность Токинской впадины сложно дифференцирована, на фоне спокойного платообразного рельефа выделяются ряд возвышенностей и котловин.

В ее южной части к юго-западу от устья р. Туксани среди мезозойских отложений отмечен выход архейских пород. Морфологически эта возвышенность (массив Беранджа) представляет собой группу островерхих гольцов с отметками до 1551 м, расположенных в пределах почти правильного семиугольника диаметром около 16 км. По склонам гольцов широко развиты осыпи. Река Алгама антецендентно пересекает названную возвышенность в северо-восточном направлении, разделяя ее на две примерно равные части. Повсеместно на левом борту р. Алгамы отмечаются на склонах следы сейсмогравитационных проявлений. Эти сведения позволяют предположить, что морфологическая выраженность Токинской впадины сохранилась лишь за счет ее отставания в поднятии от окружающих горных сооруже- 
ний. Практически всю площадь Токинской впадины занимает Алгаминский минимум поля силы тяжести. Уровень сейсмичности внутри самой впадины крайне низок $(\mathrm{M} \leq 2.5)$, но возрастает в ее северной и южной краевых частях.

Верхнезейская отрицательная морфоструктура (г) относится к ТукуринграДжагдинскому геоблоку и расположена на крайнем юге территории исследований. В целом, впадина разграничивает Тукурингра-Джагдинское и Становое сводово-блоковые поднятия. На севере границей впадины служит эрозионно-тектонический уступ высотой 30-60 м, который обрывает денудационную поверхность. Современная аккумулятивно-денудационная поверхность Верхнезейской впадины имеет абсолютные отметки 350-450 м и полого наклонена к северу. Ее формирование обусловлено мезо-кайнозойским тектоническим этапом, в период которого происходило погружение фундамента впадины и заполнение ее рыхлым материалом. Максимальная мощность рыхлых кайнозойских отложений составляет здесь около 500 м (Николаев и др., 1979).

Анализируя геометрический рисунок Тыркандинской шовной зоны (юго-восточный фланг) и Итун-Иланского разлома системы Тан-Лу (северо-западный фланг) можно диагностировать здесь наличие зоны сжатия, возникшей в области динамического влияния разломов по типу правого сдвига. К ней тяготеет крупный морфотектонический блок транспрессионного типа со структурами Токинского Становика и Токинской впадины. При правобоковом смещении вдоль рассматриваемых разрывных нарушений на северной и южной периферии и внутри названного блока закономерно возникла сеть близширотных сдвиго-взбросов и надвигов с падением сместителей в южном и северном направлениях. На рис. 5.4 эта сопряженная правосдвиговая система разломов (Тыркандинский и Итун-Иланский) показана как главная морфоконтролирующая и сейсмогенерирующая структура региона.

Сейсмогеодинамика. Протяженная (свыше 3 тыс. км) зона деструкции земной коры между Байкалом и Охотским морем, маркируемая проявлениями сейсмичности за более чем 100-летний период наблюдений на юге Сибири и Дальнем Востоке несомненно обусловлена современным транспрессионным (сжатие со скольжением) сближением Амурской и Евразийской плит в восток-северо-восточном направлении. Источником такого взаимодействия может являться столкновение Индийского субконтинента с окраинными структурами Евразии, под влиянием которого произошла коллизия и формирование отдельных микроплит и блоков различного размера на территории Китая и Монголии (Plate tectonic..., 1984; Tapponier, Molnar, 1979), в том числе в пределах Забайкалья и Приамурья. Это убедительно фиксируется проявлениями сейсмичности, которые оконтуривают границы блоков. В нашем случае пространственное размещение эпицентров землетрясений (рис. 5.1) отчетливо обосновывает выделение в буферной межплитной зоне упомянутых плит двух блоков: Забайкальского 
и Алдано-Станового. Указанный факт находит отражение в структуре рельефа исследуемой территории, развитии здесь системы активных разрывных нарушений (сдвигов, взбросов и надвигов), утолщении земной коры и возникновении крупных горных сооружений, представляющих значительную область скучивания земной коры под влиянием сжатия.

Сопоставление результатов сейсмотектонического анализа территории с данными измерений на геодезических полигонах в Южной Якутии и материалами космического позиционирования (GPS наблюдения), выполненными в последние годы, подтверждает наличие этой контактной зоны и объясняет в ней механизм блокового взаимодействия, что позволило представить модель современной сейсмогеодинамики (рис. 5.5).

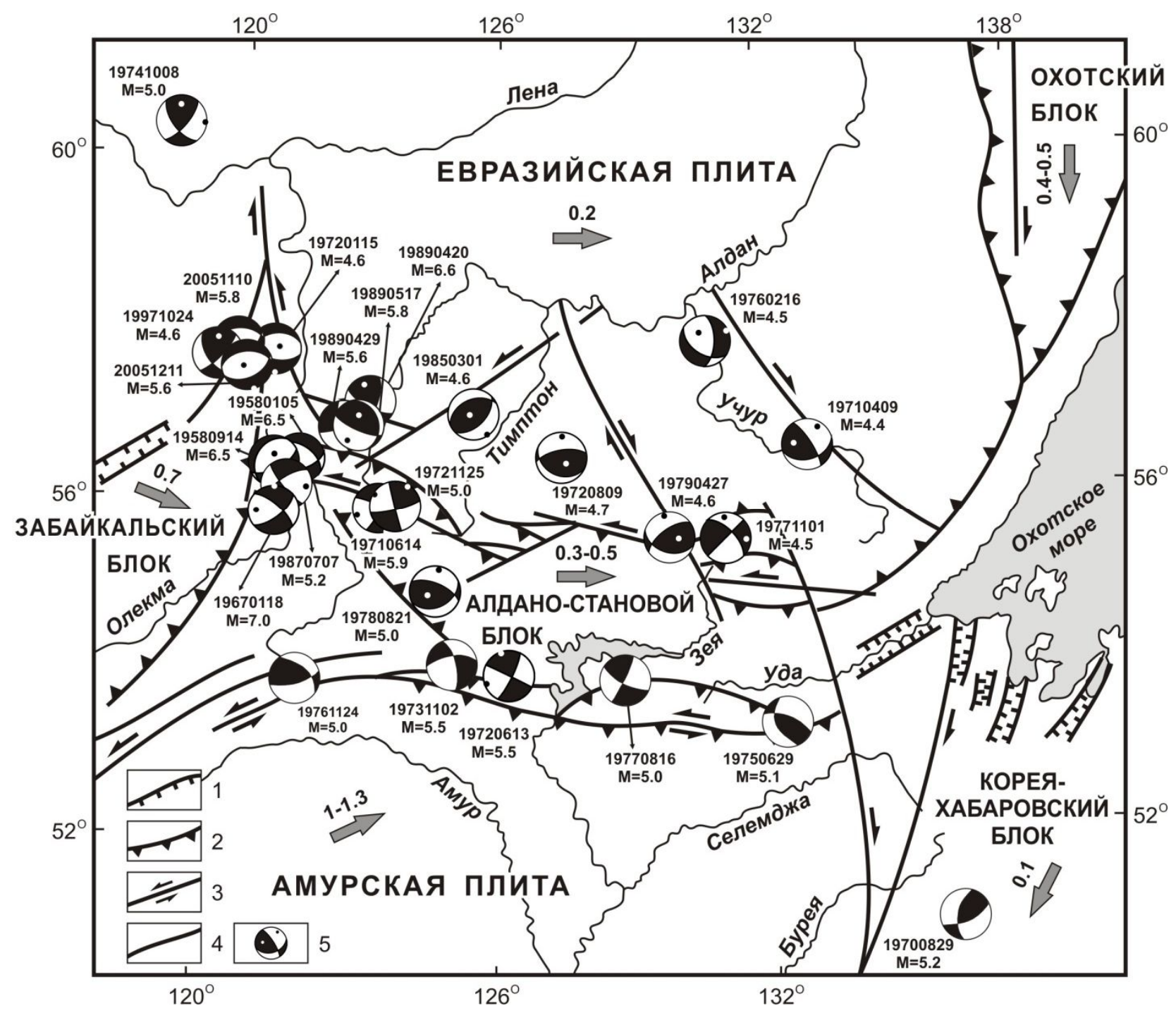

Рис. 5.5. Принципиальная схема взаимодействия структур, развитых в зоне влияния Евразийской и Амурской литосферных плит

1-4 - разломы: 1 - сбросы, 2 - взбросы и надвиги, 3 - сдвиги, 4 - неустановленной кинематики. Стрелками показаны направление движения плит и блоков, рядом их скорость смещения (см/год) по геодезическим и GPS данным (Бочаров, Замараев, 1991; Apel et al., 2006; Calais et al., 1998; Mackey et al., 2003) 
Алдано-Становой блок, зажатый между Забайкальским блоком, Евразийской и Амурской плитами, испытывает давление со стороны Забайкальского блока. Последний в связи с раскрытием Байкальского рифта смещается к юго-востоку со скоростью $0.5-0.7$ см/год (Саlais et al., 1998) и способствует перемещению Алдано-Станового блока на восток к Охотскому морю (рис. 5.5). Это не противоречит результатам триангуляционных измерений на геодинамических полигонах в районе Станового хр., где средние скорости горизонтальных смещений реперов в восточном направлении достигают 0.3 см/год (Бочаров, Замараев, 1991). При этом в зоне контакта Забайкальского и Алдано-Станового блоков в условиях сжатия возникли определенные парагенезисы активных разломов: Кодаро-Удоканские правые сдвиги, взбросо-сдвиги Темулякитской РБС, Западностановые левые сдвиги и параллельные им надвиги. Эти разломно-блоковые структуры геометрически сопряжены между собой по кинематическому типу обратной Ү-структуры. Подобный тип смещения способствует появлению на внешних флангах данной структуры областей сжатия, а внутри нее - области растяжения. Указанные соотношения находят отражение в морфоструктурных элементах современного рельефа в бассейне среднего течения р. Олекмы и подтверждаются решениями фокальных механизмов Олекминских землетрясений и группы Чаруода-Олдонгсинских событий. При этом, здесь вдоль долины р. Олекмы также формируется система взбросов и надвигов противоположной вергентности к фронтальным структурам Забайкальского блока (рис. 5.2 и 5.5$)$.

С юга на Алдано-Становой блок оказывает воздействие Амурская плита, которая смещается к восток-северо-востоку со скоростью 1-1.3 см/год (Apel et al., 2006) и поддерживает его движение в восточном направлении. В итоге, рассматриваемые структуры одновременно смещаются к востоку, но за счет меньшей скорости движения Алдано-Становой блок отстает от Амурской плиты, что способствует развитию на их границелевых сдвигов. Это согласуется с данными геоморфологических исследований в пределах Тукурингро-Джагдинской зоны, где Южно-Тукурингрский разлом трассируется вдоль полосы контрастного сочленения Верхне-Урканской впадины и поднятия хр. Тукурингра. Здесь названный разлом смещает влево (к западу) молодые (плейстоцен-голоцен) руслово-пойменные отложения в верховьях небольших северных притоков р. Уркан (правого притока р. Зеи). Максимальная амплитуда таких смещений достигает 0.8 км. В этом случае средняя скорость горизонтальных движений по типу левого сдвига, если считать, что смещение происходило с начала верхнего плейстоцена (130 тыс. лет), будет составлять 0.5-0.6 см/год (Николаев и др., 1979). Кроме того, подвижки типа левого сдвига подтверждаются параметрами фокальных механизмов сильных землетрясений (левые сдвиги, надвиги, взбросы), отмеченных в Тукурингра-Джагдинской зоне в 1972-1989 гг. (рис. 5.4). 
На восточном фланге Алдано-Станового блока (восточные части Олекмо-Становой и Тукурингра-Джагдинской сейсмотектонических зон) также отчетливо прослеживается влияние его смещения на восток. Геолого-геофизический анализ морфотектоники новейших структур этих зон позволил выявить блок сжатия (Токинский Становик и Токинская впадина) в виде мощной зоны скучивания земной коры между окончаниями двух крупных сопряженных Тыркандинской и Итун-Иланской правосдвиговых систем, простирающихся в северо-западном направлении и действующих как единая динамопара. Для нее характерно: инверсия современного рельефа во впадинах, ограничения их системами встречных надвигов и взбросов противоположной вергентности, значительные скорости вертикальных новейших и голоценовых движений в блоковых структурах (эффект выжимания) и высокая степень сейсмической активности.

При пересечении названными сдвиговыми системами субширотной зоны разрывов Станового краевого шва сформировался особый класс структур - ряд дуплексов сжатия (Qidong, Peizhen, 1984), обладающих наибольшим сейсмическим потенциалом. Ранее заложившиеся линеаменты мезозойского передового предгорного прогиба, фрагменты которого в виде Токинской впадины и целого ряда более мелких приразломных депрессий (Итымджинской, Атугей-Нуямской и др.) сохранились в настоящее время среди неотектонических поднятий, сложенных кристаллическими породами. В настоящее время они также затронуты процессами инверсии и ограничены системами надвигов и взбросов. Такое взаимоотношение между разрывами двух генеральных направлений: широтного - характерного для шовной границы между Алданским щитом и Джугджуро-Становой областью (Атугей-Нуямский и Авгенкуро-Майский левые сдвиго-взбросы), и диагонального (Тыркандинский и ИтунИланский правые сдвиги) отражает динамику взаимодействия блоков вблизи северовосточной границы Амурской плиты. При этом одним из источников возникновения северозападного сжатия, под влиянием которого происходит активизация названных сдвигов, в частности Итун-Иланского разлома, проникающего в пределы Алданского щита, скорее всего, являются движения по протяженной системе разломов Тан-Лу в Северном Китае, а также воздействие о стороны зоны Тихоокеанской субдукции (Малышев и др., 2006).

Процесс направленного перемещения к востоку Алдано-Станового блока совместно с Амурской плитой способствует также формированию на крайнем востоке в пределах Северного Приамурья и юга Дальнего Востока субдолготных структур сжатия, представленных крупной горной системой (хребты: Турана, Буреинский, Баджальский и др.), и появлению за ней, восточнее, структур растяжения в виде Тугуро-Амгинских впадин (рис. 5.5).

Комплексный анализ геолого-геофизических, структурно-тектонических, тектонофизических, наземных геодезических и GPS данных, а также построение дополнительных схем, 
характеризующих новейший этап развития и морфотектонический план горно-складчатого обрамления юга Сибирской платформы, позволил оконтурить здесь два активных в настоящее время региональных блока (Забайкальский и Алдано-Становой), возникших в буферной зоне при сближении Евразийской и Амурской литосферных плит.

Предложенная модель сейсмогеодинамики отражает процесс направленного перемещения к востоку Забайкальского и Алдано-Станового геоблоков, а также Амурской плиты, которые, двигаясь с разными скоростями, смещаются относительно друг друга и стабильной Евразийской плиты в субширотном направлении (рис. 6). При этом, для пограничной зоны Забайкальского и Алдано-Станового блоков выявлена мозаика разломно-блоковых структур в условиях смены тектонического режима растяжения (северо-восточное окончание Байкальского рифта) на сжатие (Становая и Тукурингра-Джагдинская складчатые системы).

Восточный фланг Алдано-Станового блока располагается в области как динамического влияния восточного сегмента транспрессионной области между Евразийской и Амурской литосферными плитами, так и активного воздействия со стороны зоны Тихоокеанской субдукции. Вследствие этого здесь имеют место системы активных разрывных нарушений (сдвигов, взбросов и надвигов), утолщение земной коры и возникновение крупных горных сооружений, представляющих значительную область скучивания под влиянием северовосточного сжатия (Токинский Становик в Южной Якутии, хребты Турана, Буреинский, Баджальский в Приамурье и др.). Результатом этих процессов явилось образование на востоке Алдано-Станового блока дуплекса сжатия в зоне динамического влияния двух крупных сопряженных правосдвиговых систем северо-западного простирания - Тыркандинского и Итун-Иланского. Возникновение Итун-Иланского сдвиго-взброса, входящего в систему активных разломов Тан-Лу, протягивающихся параллельно обрамлению Японского и Охотского морей, обусловлено, по-видимому, влиянием Тихоокеанской субдукции и особенностями сейсмотектоники Северного Китая.

Таким образом, рассматривая общий сейсмогеодинамический режим обширной территории обрамления юга Сибирской платформы в Забайкалье, Приамурье, на Дальнем Востоке, в Северном Китае и Монголии, можно составить объективную картину протекающих здесь сейсмотектонических процессов и пытаться прогнозировать динамику их развития. 


\section{2. АРКТИКО-АЗИАТСКИЙ СЕЙСМИЧЕСКИЙ ПОЯС}

Комплексные геолого-геофизические и сейсмологические исследования выявили на территории северо-востока Азии протяженный Арктико-Азиатский (ААСП) сейсмический пояс (Имаева и др., 2011; Chapman, Solomon, 1976; Mackey et al., 2007), геодинамические процессы в котором являются индикаторами сейсмотектонических деформационных преобразований земной коры в зонах контактного взаимодействия крупных литосферных плит (Североамериканской и Евразийской). В пределах ААСП зарегистрировано около 100 тыс. сейсмических событий, среди которых более чем 20 были катастрофическими (M>6.5) и представляли собой реальную угрозу населению. В структурно-тектоническом плане ААСП подразделяется на несколько крупных региональных сегментов (Лаптевоморский, Хараулахский, Черского и Охотоморский) с развитием в их пределах характерных структурных парагенезисов, связанных с определенным типом напряженного состояния земной коры (Имаев и др., 2000, 2009; Козьмин и др., 2001). Каждому из названных сегментов соответствуют ряд специфических особенностей сейсмотектонических процессов, собственная структура пространственно-временного распределения сейсмических событий, поля тектонических напряжений, характерные типы активных разломов, индивидуальные характеристики геофизических полей и др. Все эти данные позволяют лучше понять тектоническую природу местных землетрясений и решить проблему прогноза изменений сейсмического режима в пространстве и во времени.

Арктический (Лаптевоморский) сегмент. Сейсмичность в акватории Северного Ледовитого океана представлена «цепочкой» эпицентров землетрясений, прослеживающихся параллельно линии островов Шпицберген - Земля Франца Иосифа - Северная Земля от трансформного разлома Де-Гира, трассируемого между островами Шпицберген и Гренландия, к устью реки Лены. Пространственно она тяготеет к структурам срединноокеанического хребта Гаккеля, вытянутого на 1700 км при ширине 80-160 км от Гренландского шельфа к шельфу моря Лаптевых. В Арктической сейсмической зоне с начала века отмечено свыше 150 местных землетрясений с магнитудой 4.5-7.0. Очаги землетрясений груп-

пируются здесь, главным образом, в пределах земной коры (Аветисов, 1996; Fujita et al., 1990).

Арктический хр. Гаккеля входит в мировую систему подводных срединноокеанических хребтов Земли и является ее северным фрагментом, продолжающим Североатлантический срединно-океанический хребет в бассейн Северного Ледовитого океана. Сейсмичность хребта Гаккеля обусловлена процессами рифтогенеза и соответственно растяжением земной коры, вызывающим спрединг океанического дна (Грачев и др., 1973; Savostin, Karasik, 1981; Grachev, 1982). Это подтверждается данными фокальных механизмов (сбросо- 
вые подвижки в очагах местных землетрясений) и особенностями пространственного распределения магнитного поля. Так, в центральной части хр. Гаккеля число аномалий магнитного поля составляет 47, а на его южном окончании оно уменьшается до 6. При этом скорость спрединга понижается от 0.6-0.7 см/год в центре рифта хр. Гаккеля до 0.3 см/год на его южном окончании (Карасик, 1968).

Имеющиеся в настоящее время морские геофизические данные, позволили выявить характерные особенности строения шельфа (Аветисов, Гусева, 1991; Аветисов, 1996; Грамберг и др., 1990). Основными структурными единицами шельфа являются протяженные грабены и разделяющие их поднятия (горсты), занимающие его южную часть, и образующие рифтовую систему моря Лаптевых. По последним данным, она прослеживается далее на север за пределы изученной территории и, по-видимому, сочленяется в области континентального склона с зоной хр. Гаккеля.

Выявленные зоны эпицентров землетрясений (Лено-Таймырская и Новосибирских островов) совместно с основной полосой, возможно, оконтуривают на шельфе моря Лаптевых два блока: западный (Лаптевоморский) и восточный (Новосибирских островов), расположенных по обе стороны от границы Евразийской и Североамериканской плит. При этом, на западной границе Лаптевоморского блока (район Таймыра) и восточной границе блока Новосибирских островов (район шельфа Восточно-Сибирского моря) по данным фокальных механизмов (рис. 5.6), по-видимому, существует режим сжатия как реакция на рифтинг, действующий в пределах основной зоны эпицентров (хр. Гаккеля). Именно образование названных блоков, возможно, объясняет наличие диффузной сейсмичности на шельфе моря Лаптевых. 


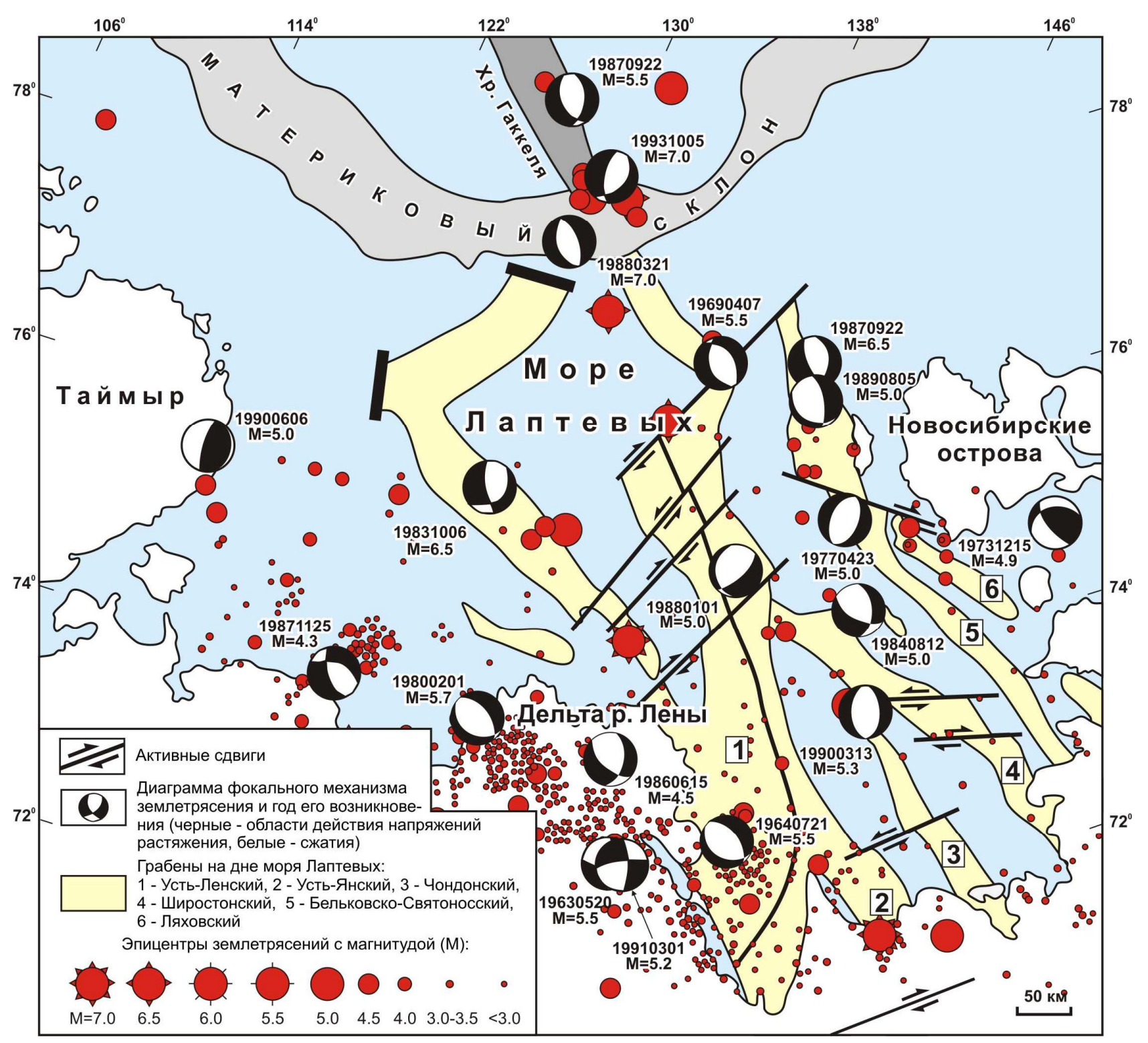

Рис. 5.6. Эпицентры землетрясений (М>4.5) и фокальные механизмы шельфа моря Лаптевых (nо (Fujita, Kozmin, 1994))

Хараулахский сегмент. Сопоставление местоположения очагов местных землетрясений с особенностями «живой» тектоники Хараулахской зоны показывает, что эпицентры землетрясений тяготеют, главным образом, к выявленным крупным системам разрывных нарушений (Хараулахской, Приморской, Буорхаинской и Западноверхоянской) подтверждая их активность в современное время. Эпицентры землетрясений фиксируются здесь в обширной (до 300 км) области между низовьями рек Лены и Яны (Козьмин, 1984; Имаев и др., 1990). Главные напряжения, действующие в очагах землетрясений, имеют различные азимуты простирания и углы падения от горизонтальных до субвертикальных (рис. 5.7). Это может свидетельствовать, что сейсмический процесс в Хараулахской зоне развивается как в условиях растяжения, так и сжатия. В целом, земная кора находится здесь под воздействием неоднородного поля тектонических напряжений. Для зоны характерно смешанное поле тектониче- 
ских напряжений, при котором в очагах землетрясений на севере Верхоянья наблюдаются сбросовые (Приморская система сбросов на западном побережье губы Буор-Хая), сдвиговые (Хараулахская система сдвиго-сбросов), надвиговые (Западно-Верхоянские чешуйчатые надвиги) и взбросовые (Найбинский кряж) смещения (судя по характеру фокальных механизмов и данным геолого-геофизических наблюдений за морфокинематическими характеристиками разломов).

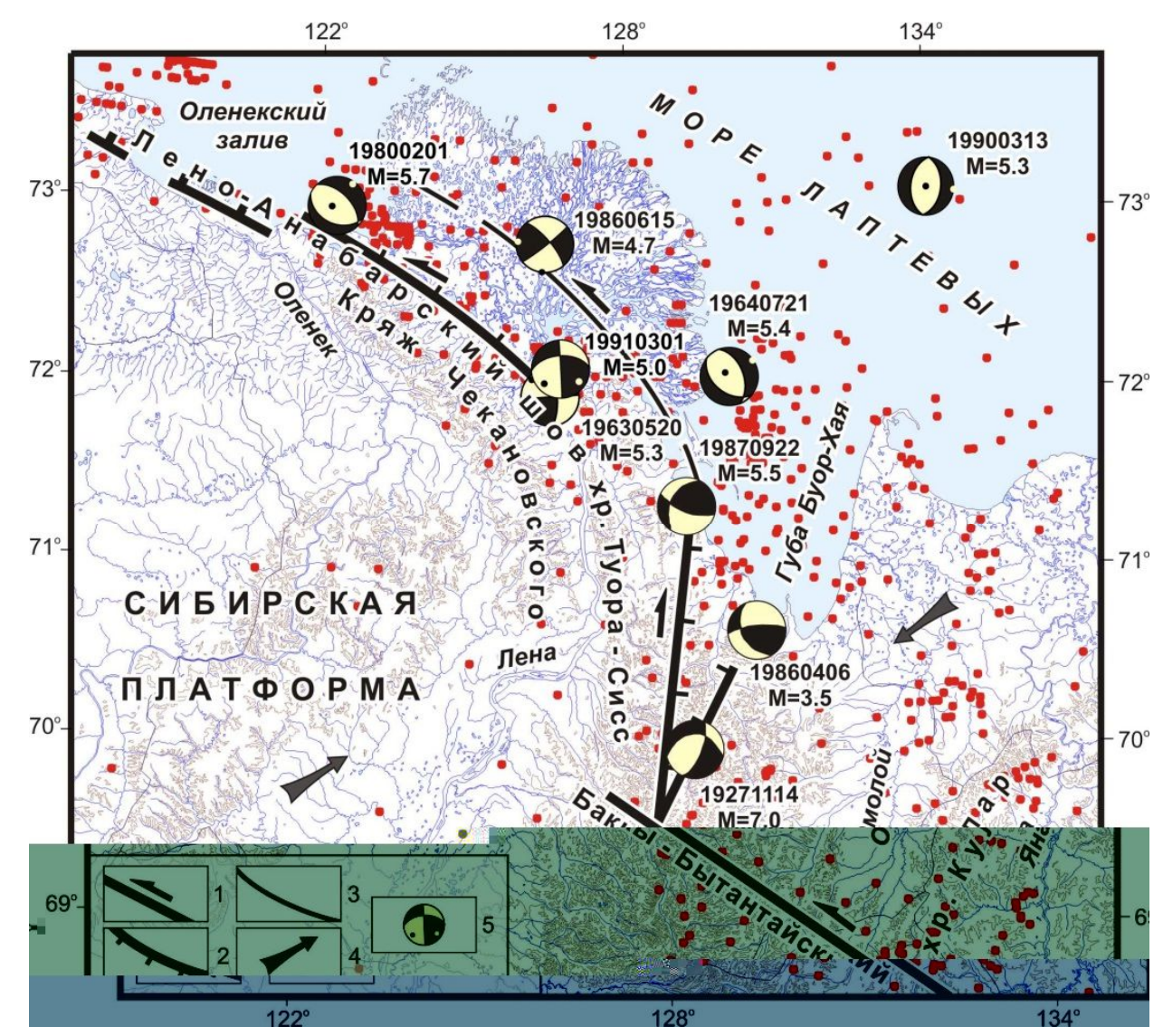

Рис. 5.7. Хараулахский сегмент.

Эпицентры землетрясений, фокальные механизмы и динамика

Структурообразуюшие разломы: 1 - сдвиги; 2 - сбросы; 3 - надвиги; 4 - направление относительного движения плит; 5 - круговые диаграммы механизмов (светлье области - действие напряжений сжатия, темные - напряжений растяжения)

Таким образом, на севере Якутии существует уникальная переходная область изменения полей тектонических напряжений растяжения на сжатие, в пределах которой сочленяются срединноокеанические и континентальные структуры земной коры. На земном шаре существуют лишь несколько подобных областей. К ним, например, относятся район Афарского рифта (Восточная Африка), структуры которого взаимосвязаны со структурами срединноокеанического хребта в Индийском океане, и район Северной Калифорнии, где северное окончание Восточно-Тихоокеанского поднятия, через разлом Сан-Андреас, соединяется с системой срединноокеанических хребтов Горда, Хуан де Фука и Эксплорер в Тихом океане. 
Сейсмотектоническая зона Черского. Обобщение материалов инструментальных наблюдений, принадлежащих филиалам Геофизической службы РАН, СО РАН и Университета штата Мичиган (США), отображенных на карте сводной сейсмичности северо-востока России (Fujita et al., 2009; Mackey et al., 2007), а также совместный анализ данных геологоструктурных (Парфенов и др., 2001) и морфотектонических (Имаева и др., 2009) исследований позволили уточнить динамику сейсмогенерирующих структур составляющих сегментов сейсмотектонической зоны Черского и разработать региональную структурно-динамическую модель. По особенностям структурных парагенезисов, связанных с определенным типом напряженного состояния земной коры (Гусев, 1979; Имаева и др., 2011; Парфенов и др., 2001), строению геофизических полей (Суворов, Корнилова, 1986; Fujita et al., 2009), а также общему морфотектоническому плану (Имаев и др., 2000, 2009) и динамике главных сейсмогенерирующих структур (Имаев и др., 2009; Имаева и др., 2009) в системе мезозоид сейсмотектонической зоны Черского выделяются Яно-Индигирский и Индигиро-Колымский (Охотский) региональные сегменты, расположение которых нанесено на рисунок 5.8. 


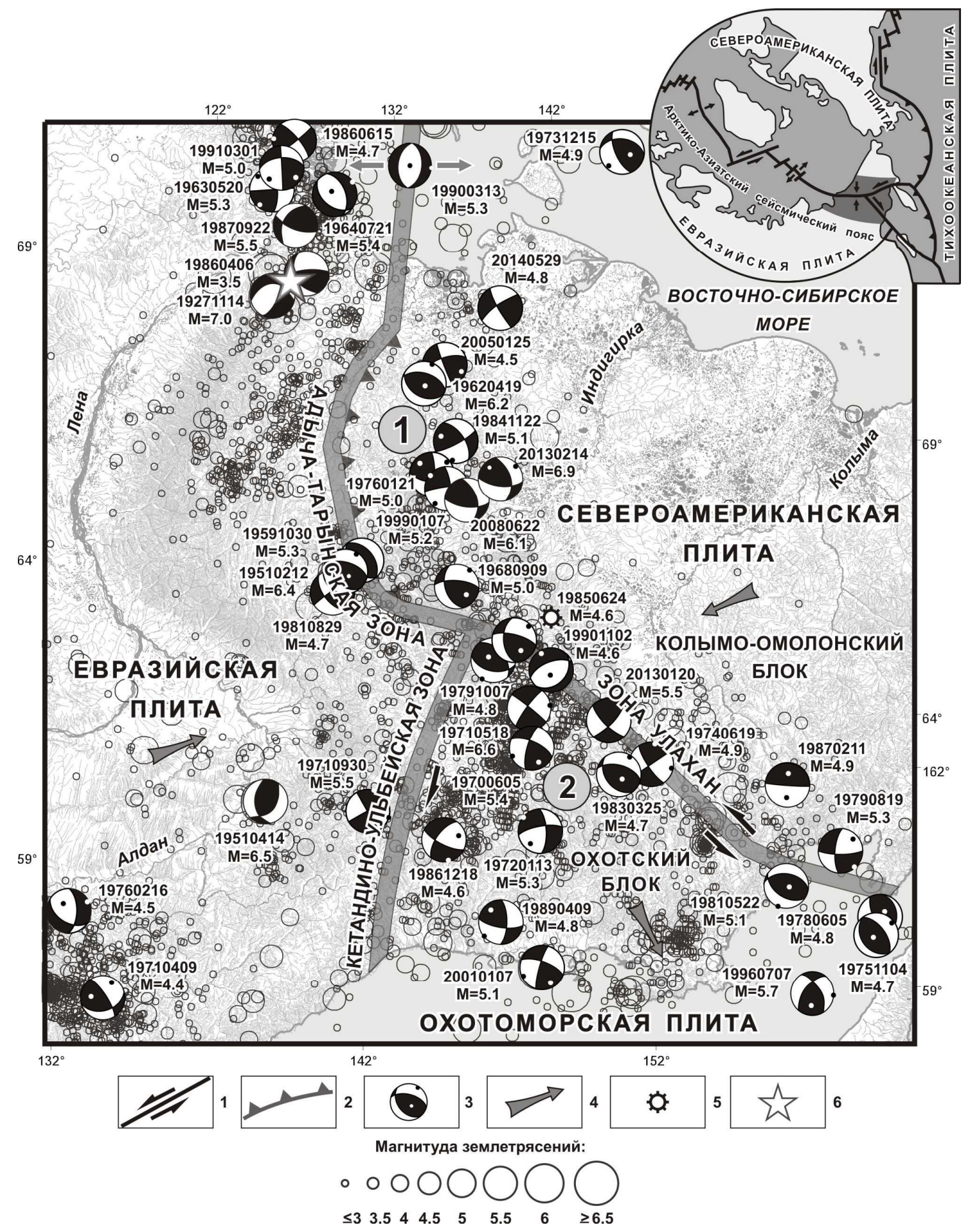

Рис. 5.8. Схема эпицентров землетрясений и механизмов очагов сильных сейсмических событий сейсмотектонической зоны Черского (континентальная часть Арктико-Азиатского сейсмического пояса).

Составлена по материалам ГФ РАН и СО РАН

1-2 - активные разломы: 1 - сдвиги, 2 - надвиги и взбросы; 3-механизм очагов сильных землетрясений с указанием их даты и магнитуды, бельм изетом обозначены области сжатия. 4 - направление движения литосферных плит и блоков; 5 - вулкан Балаган-Тас; 6 - полюс вращения плит. В кружках иүифрами обозначены составляющие сегменты сейсмотектонической зонь Черского: 1 - Яно-Индигирский; 2 - Индигиро-Колымский 
Яно-Индигирский сегмент сейсмотектонической зоны Черского в морфотектоническом плане представлен деформационными структурами северного и северо-западного флангов фронтальной зоны взаимодействия между Евразийской и Североамериканской плитами (рис. 5.9). Зона коллизии, обладающая специфическим от смежных деформационных зон глубинным строением (Суворов, Корнилова, 1986; Fujita et al., 2009), включает коллаж тектонических структур (террейнов), возникших в определенных геодинамических условиях (Парфенов и др., 2001) и характеризуется комплексом морфотектонических и разрывных элементов (разломно-блоковых структур) (Имаев и др., 2000, 2009).

В структурно-тектоническом плане сегмент включает фронтальные зоны КолымоОмолонского блока и ряд террейнов (Полоусно-Дебинский, Омулевский, Нагоджинский и др.) различной геодинамической природы, расположенных к северу и северо-западу от среднего течения р. Индигирка. По серии северо-западных разломов, преимущественно левосдвиговой кинематики, террейны разобщены на серию разломно-блоковых структур (Имаева и др., 2011; Имаев и др., 2000), наиболее крупные из которых-Чемалгинский, ТасХаяхтахский, Селенняхский.

В становлении современного рельефа Яно-Индигирского сегмента основную роль играют разломы позднемезозойского времени заложения и активизированные в кайнозое. Анализ кинематических типов активных разломов и деформаций в кайнозойских отложениях (Имаева и др., 2009, 2011; Имаев и др., 2000, 2009), установленных на северно-восточном фланге Яно-Индигирского сегмента, показал, что на этой территории развиты дизъюнктивы различного ранга и генезиса преимущественно надвиговой, взбросо-сдвиговой и сдвиговой динамики. Амплитуды горизонтальных перемещений по разломам оцениваются впервые десятки километров (Гусев, 1979).

Для анализа динамики формирования сейсмогенерирующих структур сегмента наиболее показательна разломная система, трассируемая в Илинь-Тасской складчатой зоне вдоль осевой части Момского хребта (рис. 5.9). В плане, южные кулисы разнонаправленной системы Илинь-Тасского (левый сдвиг) и Арга-Тасского (правый сдвиг) разломов сопряжены под косым углом примерно в центре Момского хребта, создавая к северо-западу и юго-востоку веерообразные зоны сжатия, представленные широким спектром складчатых деформаций в кайнозойских отложениях Индигиро-Зырянского прогиба и Момо-Селенняхских депрессий (Имаева и др., 2009, 2011; Имаев и др., 2000, 2009). Перед фронтальной областью сопряжения закономерно расположена зона растяжения, морфологически представленная субширотной долиной среднего течения р. Мома, где расположен кайнозойский вулкан Балаган-Тас, крупнейшая в мире наледь Улахан-Тарын и отмечаются многочисленные минерализированные термальные источники подземных вод (Грачев, 1996). 


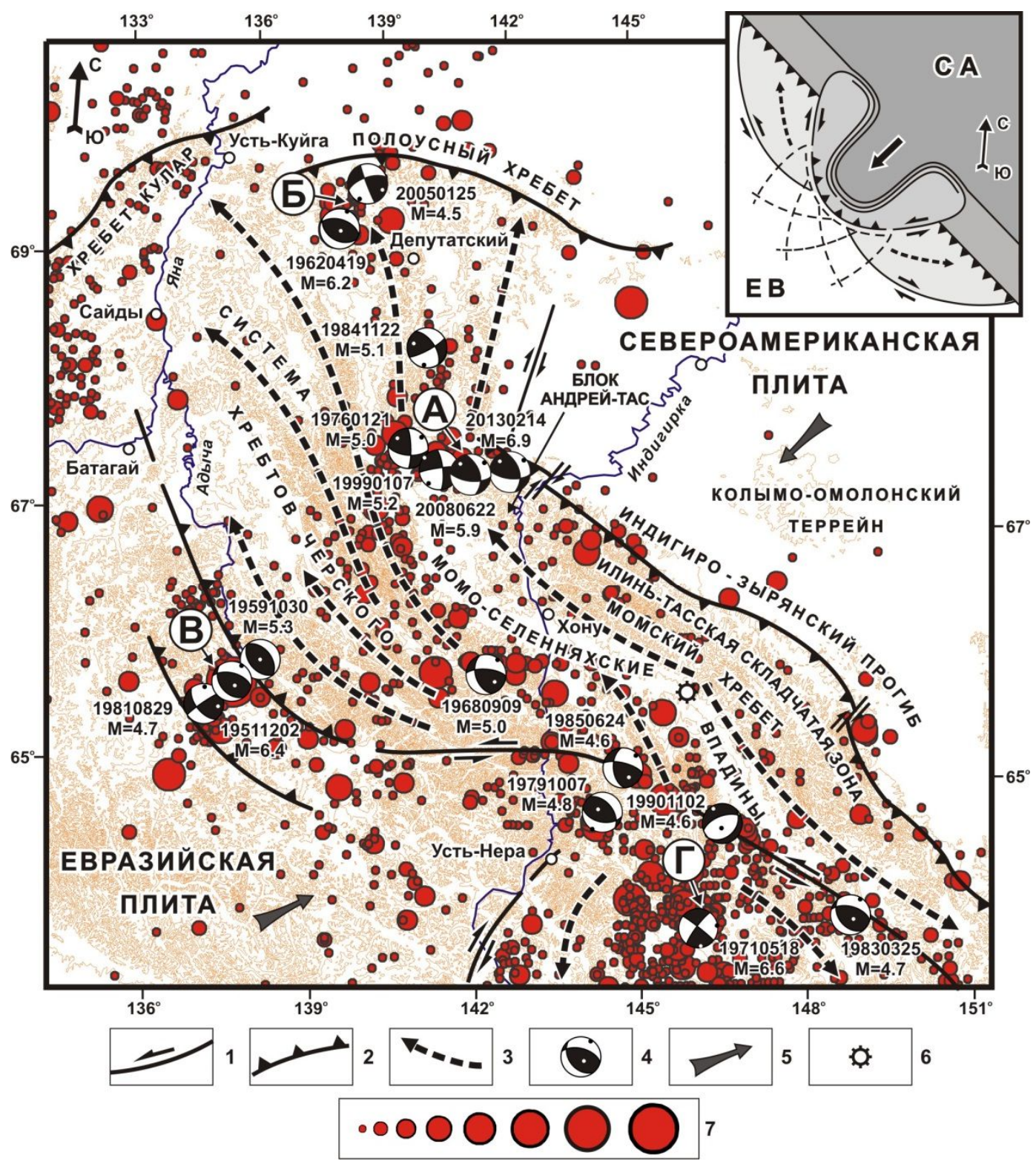

Рис. 5.9. Схема современной динамики и эпицентров землетрясений

Яно-Индигирского сегмента сейсмотектонической зоны Черского (Арктико-Азиатский сейсмический пояс) (по (Имаева и др., 2009, 2011), с дополнениями)

1-2 - активные разломы: 1 - сдвиги, 2 - надвиги и взбросы; 3 - направления перемещчения блоков; 4 - стереограммы механизмов очагов землетрясений, рядом проставлена дата их возникновения и магнитуда; 5 - направление движения литосферных плит; 6 - вулкан Балаган-Тас; 7 - энергетический класс землетрясений ( $K=\lg$ Е Дюс.), равный соответственно: $\leq 9,10,11,12,13,14,15, \geq 16$. Во вставке показана упрощенная модель пластической деформации Альn (no (Moores, Twiss, 1995))

Совместный анализ особенностей активной тектоники и проявлений сейсмичности выявил определенную закономерность в кинематических характеристиках фокальных механизмов сильных землетрясений и пространственного распределения очагов сильных землетрясений (рис. 5.9). Напряженное состояние земной коры исследовано на основе механизмов очагов землетрясений в зоне взаимодействия Колымо-Омолонского блока и Евразийской 
плиты (табл. 5.1). Для землетрясений сейсмотектонической зоны Черского характерно то, что все они происходят в условиях устойчивого северо-восточного сжатия. При этом сжимающие усилия близгоризонтальны (углы падения 3-44º и действуют вкрест простирания структурных элементов территории. Напряжения растяжения часто совпадают по простиранию с линиями разломов и ориентированы как горизонтально, так и близвертикально по отношению к земной поверхности (углы падения 2-85²). Оси промежуточного напряжения имеют беспорядочную пространственную ориентацию и широкий интервал углов падения от 0 до $82^{0}$. При этом названная ориентация напряжений в очагах землетрясений господствует на всем протяжении от Северного Верхоянья до Охотского моря (рис. 5.8).

Таблица 5.1

Параметры фокальных механизмов землетрясений в зоне взаимодействия Колымо-Омолонского блока и Евразийской плиты

\begin{tabular}{|c|c|c|c|c|c|c|c|c|c|c|c|c|c|}
\hline \multirow[t]{2}{*}{ № } & \multirow[t]{2}{*}{$\begin{array}{c}\text { Год. мес. } \\
\text { число }\end{array}$} & \multirow{2}{*}{$\begin{array}{c}\text { Время } \\
\text { в } \\
\text { очаге } \\
\text { час. } \\
\text { мин. }\end{array}$} & \multirow{2}{*}{$\begin{array}{l}\varphi, N \\
\text { гра- } \\
\text { дус }\end{array}$} & \multirow{2}{*}{$\begin{array}{l}\lambda, E \\
\text { гра- } \\
\text { дус }\end{array}$} & \multirow[t]{2}{*}{$\mathrm{M}$} & \multicolumn{2}{|c|}{$\sigma_{1}$} & \multicolumn{2}{|c|}{$\sigma_{2}$} & \multicolumn{2}{|c|}{$\sigma_{3}$} & \multirow[t]{2}{*}{$\begin{array}{c}\text { Тип } \\
\text { под- } \\
\text { виж- } \\
\text { ки }\end{array}$} & \multirow[t]{2}{*}{$\begin{array}{l}\text { Ис- } \\
\text { точ- } \\
\text { ник }\end{array}$} \\
\hline & & & & & & Azm & $\mathrm{Pl}$ & Azm & Pl & Azm & $\mathrm{Pl}$ & & \\
\hline 1 & 1951-02-12 & $17-22$ & 65.0 & 137.0 & 6.4 & & & & & & & & \\
\hline 2 & 1959-10-30 & 04-00 & 66.0 & 137.5 & 5.2 & - & 90 & 320 & 00 & 230 & 00 & $\mathrm{~B}$ & \\
\hline 3 & 1962-04-19 & $23-16$ & 69.5 & 138.5 & 6.2 & 151 & 83 & 292 & 06 & 22 & 05 & B & \\
\hline 4 & 1968-09-09 & $02-20$ & 66.2 & 142.1 & 5.0 & 130 & 43 & 300 & 46 & 38 & 07 & B-C & \\
\hline 5 & 1970-06-05 & $10-31$ & 63.3 & 146.2 & 5.4 & 154 & 30 & 346 & 60 & 247 & 06 & $\mathrm{C}$ & \\
\hline 6 & 1971-05-18 & $22-44$ & 64.0 & 146.1 & 6.6 & 172 & 09 & 334 & 80 & 82 & 03 & $\mathrm{C}$ & \\
\hline 7 & 1971-09-30 & $21-31$ & 61.6 & 140.4 & 5.5 & 16 & 00 & 283 & 88 & 107 & 01 & $\mathrm{C}$ & \\
\hline 8 & 1972-01-13 & $17-24$ & 61.9 & 147.0 & 5.3 & 309 & 02 & 44 & 60 & 219 & 29 & $\mathrm{C}$ & \\
\hline 9 & 1974-06-19 & 03-09 & 63.2 & 151.0 & 4.9 & 10 & 08 & 236 & 78 & 101 & 08 & $\mathrm{C}$ & \\
\hline 10 & 1976-01-21 & 06-02 & 67.7 & 140.2 & 5.0 & 313 & 27 & 163 & 58 & 50 & 14 & C-B & \\
\hline 11 & 1979-10-07 & $01-29$ & 65.0 & 144.0 & 4.8 & 304 & 69 & 120 & 21 & 211 & 02 & $\mathrm{~B}$ & \\
\hline 12 & 1981-08-29 & $22-24$ & 65.5 & 136.4 & 4.7 & 101 & 28 & 245 & 57 & 03 & 17 & $\mathrm{C}$ & \\
\hline 13 & 1982-09-03 & $07-29$ & 66.9 & 133.3 & 4.5 & 72 & 05 & 177 & 67 & 339 & 20 & $\mathrm{C}$ & \\
\hline 14 & 1983-03-25 & $10-37$ & 63.6 & 149.9 & 4.7 & 144 & 69 & 298 & 18 & 32 & 09 & $\mathrm{~B}$ & \\
\hline 15 & 1984-11-22 & $13-53$ & 68.5 & 140.8 & 5.1 & 288 & 31 & 79 & 56 & 190 & 14 & C-B & \\
\hline 16 & $1985-06-24$ & $03-55$ & 65.3 & 144.7 & 4.6 & 148 & 44 & 304 & 44 & 46 & 12 & C-B & \\
\hline 17 & 1987-02-11 & $00-58$ & 62.8 & 156.9 & 4.9 & 04 & 48 & 274 & 00 & 184 & 42 & $\mathrm{~B}$ & \\
\hline 18 & 1999-01-07 & 18-14 & 67.6 & 140.9 & 5.2 & 309 & 06 & 59 & 74 & 218 & 15 & $\mathrm{C}$ & \\
\hline 19 & $2005-01-25$ & $22-22$ & 69.8 & 138.3 & 4.5 & 112 & 21 & 332 & 64 & 208 & 16 & C-B & \\
\hline 20 & 2006-10-19 & $07-16$ & 64.1 & 148.9 & 5.2 & 356 & 31 & 139 & 53 & 254 & 18 & $\mathrm{C}$ & \\
\hline 21 & $2008-06-22$ & $22-57$ & 67.7 & 141.3 & 6.1 & 313 & 50 & 131 & 40 & 222 & 01 & C-B & \\
\hline 22 & $2013-01-20$ & $10-48$ & 64.9 & 146.7 & 5.7 & 355 & 30 & 150 & 57 & 258 & 12 & $\mathrm{C}$ & \\
\hline 23 & $2013-02-14$ & $13-13$ & 67.6 & 142.5 & 6.9 & 324 & 76 & 129 & 13 & 220 & 3 & $\mathrm{H}$ & \\
\hline 24 & $2013-05-10$ & $08-38$ & 67.5 & 139.3 & 5.4 & 37 & 74 & 127 & 0 & 217 & 14 & $\mathrm{H}$ & \\
\hline
\end{tabular}

Примечание: $\varphi, N, \lambda, E$ - координаты эпицентра землетрясения: северная широта и восточная долгота соответственно; $M$ - магнитуда землетрясения; $\sigma_{1}, \sigma_{2}, \sigma_{3}$ - напряжение растяжения, промежуточное и сжатия соответственно (Аzm - азимут оси напряже-

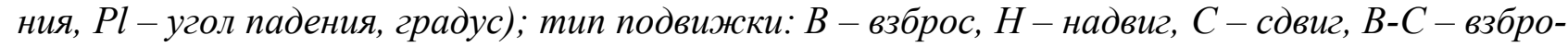
со-сдвиг, $C$-В - сдвиго-взброс 
Кинематика главных тектонических напряжений, выявленная по сейсмологическим данным, указывает на то, что большинство фокальных механизмов землетрясений сейсмотектонической зоны Черского соответствует взбросам, надвигам и сдвигам. Из 30 таких определений 39 \% составляют взбросы, 30 \% - сдвиги, 17 \% - надвиги, остальные - сочетание сдвигов и сбросов (14 \%). Полученные материалы свидетельствуют, что сейсмический процесс в СЗЧ протекает в условиях сжатия по зоне генеральных сдвигов, сопряженных с системами надвигов и взбросов.

На рисунке 5.8 хорошо прослеживается структурная организация главных сейсмогенных зон всей сейсмотектонической зоны Черского. Так, сгущение эпицентров, группирующееся вдоль линии разлома Улахан, продолжается на левобережье р. Индигирки по трассе Чибагалахского разрывного нарушения, но затем вблизи $140^{\circ}-141^{\circ}$ восточной долготы круто меняет своt северо-западное простирание на долготное. При этом, полоса эпицентров землетрясений пересекает почти вкрест простирания систему Момо-Селенняхской впадин и вдоль западного склона кряжа Андрей-Тас следится к Полоусному хребту, тяготея к Селенняхскому разлому.

В Яно-Индигирском сегменте выделяется несколько максимумов сейсмической активности (рис. 5.9). Наиболее интенсивен из них, сейсмический максимум блока Андрей-Тас (рис. 5.10), где наряду с многочисленными слабыми сотрясениями ранее отмечены 7 балльное Уяндинское событие 1984 г. с $\mathrm{M}_{\mathrm{s}}=5.6$, 6-7-балльное землетрясение 1999 г. с $\mathrm{M}_{\mathrm{s}}=5.2$, 8-балльное Андрей-Тасское событие 2008 г. с $\mathrm{M}_{\mathrm{s}}=6.1$. Для многих сильных землетрясений в пределах всей сейсмотектонической зоны Черского ранее были составлены схемы изосейст (Имаева и др., 2011; Имаев и др., 2000; Козьмин, 1984). Для них обнаруживается четкая тенденция: все изосейсты, оконтуривающие территорию определенной балльности, представляли собой эллипсы, большая ось которых вытянута в северо-западном направлении вдоль простирания трасс главных сейсмоактивных разломов (табл. 5.2). Исключение составили лишь землетрясения сейсмического максимума блока Андрей-Тас (Имаева и др., 2009, 2011). 


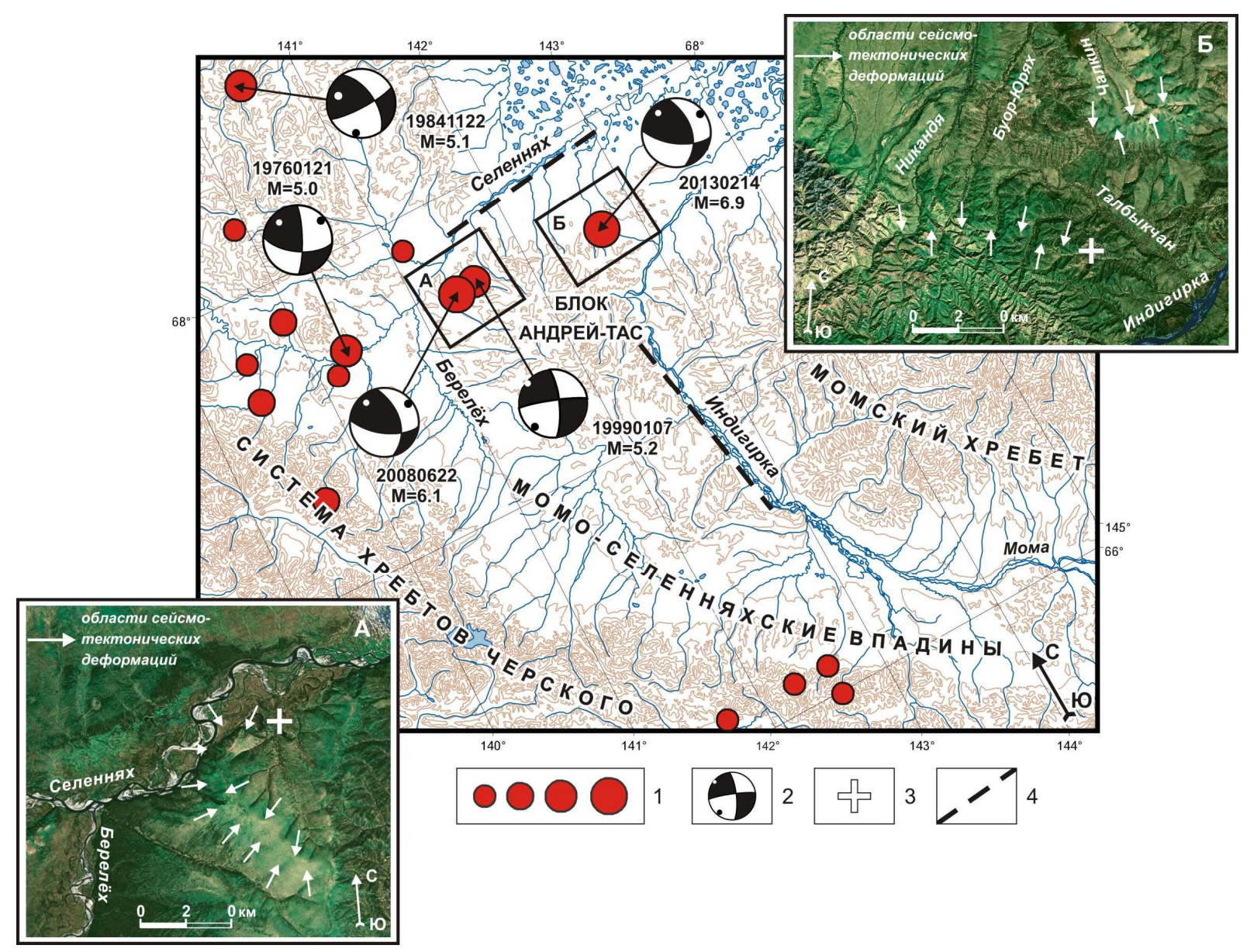

Рис. 5.10. Сильные землетрясения северо-восточного борта

Момо-Селенняхских впадин в пределах Андрей-Тасского сейсмического максимума (по (Имаева и др., 2011) с дополнениями)

1 - эпицентры землетрясений с магнитудой $M$ (икала Рихтера), соответственно: 3.0-3.9, 4.0-4.9, 5.0-5.9, 6.0-6.9; 2 - стереограммы фокальных механизмов землетрясений, рядом проставлена дата их возникновения и магнитуда; 3 - эпищентр Илин-Тасского (Абыйского) землетрясения. $B$ квадрате $A$ - обозначены эпицентральные области землетрясений 07.01.1999 и 22.06.2008 г2., в квадрате Б - эпищентральная область Илин-Тасского землетрясения 14.02.2013 г., после которых возникли сейсмотектонические деформачии, показанные во вставках рисунка

Различие между плановым рисунком изосейст, которые вкрест простирания пересекают зоны активных тектонических нарушений в сейсмическом максимуме блока Андрей-Тасс и контурами изосейст, расположенных вдоль трасс разломов в других частях сейсмотектонической зоны хр. Черского, можно объяснить динамикой зоны максимального сжатия со стороны Колымо-Омолонского блока (рис. 5.9). В рассматриваемом районе в зоне контакта между Евразийской Североамериканской плитами происходит накопление значительных тектонических напряжений, что способствует активизации сейсмотектонических процессов. Генеральное направление воздействия индентора определяется пространственным положением изосейст, которые под его влиянием оказались вытянутыми поперек структурных элементов в направлении северо-восток-юго-запад по азимуту 50-85․ Данная динамическая обстанов- 
ка способствовала созданию к северу и северо-западу поперечных зон сжатия в виде системы взбросов и надвигов (Полоусно-Дебинский блок), а также широкого спектра складчатых деформаций в кайнозойских отложениях Индигиро-Зырянского прогиба.

\section{Макросейсмические особенности сильных землетрясений в сейсмотектонической зоне Черского}

Таблица 5.2

\begin{tabular}{|c|c|c|c|c|c|c|c|}
\hline $\begin{array}{c}\text { Дата возникно- } \\
\text { вения } \\
\begin{array}{c}\text { землетрясения } \\
\text { год мес. число }\end{array}\end{array}$ & $\varphi^{\mathrm{o}}, \mathrm{N}$ & $\lambda^{\mathrm{o}}, \mathrm{E}$ & $\mathrm{M}$ & $\mathrm{I}_{\mathrm{O}}$ & $\begin{array}{c}\text { Форма } \\
\text { изосейст }\end{array}$ & $\begin{array}{c}\text { Направление про-- } \\
\text { стирания большой } \\
\text { оси изосейст }\end{array}$ & $\begin{array}{c}\text { Площадь } \\
\text { ощутимых } \\
\text { сотрясений } \\
\text { тыс. км }\end{array}$ \\
\hline $1951-02-12$ & 65.0 & 137.0 & 6.4 & $8-9$ & круговая & - & $\sim 400$ \\
\hline $1962-04-19$ & 69.5 & 138.5 & 6.2 & $7-8$ & эллипс & с-запад-ю-восток & 170 \\
\hline $1970-06-05$ & 63.3 & 146.2 & 5.4 & 7 & - & - & $\sim 100$ \\
\hline $1971-05-18$ & 64.0 & 146.1 & 7.0 & 9 & эллипс & с-запад-ю-восток & 900 \\
\hline $1971-09-30$ & 61.6 & 140.4 & 5.5 & 7 & эллипс & субдолготное & 200 \\
\hline $1972-01-13$ & 61.9 & 147.0 & 5.3 & 7 & эллипс & с-запад-ю-восток & 200 \\
\hline $1974-06-19$ & 63.2 & 151.0 & 4.9 & $6-7$ & эллипс & с-запад-ю-восток & 160 \\
\hline $1984-11-22$ & 68.5 & 140.8 & 5.1 & 7 & эллипс & с-восток-ю-запад & $\sim 100$ \\
\hline $2005-01-25$ & 69.8 & 138.3 & 4.5 & 6 & эллипс & с-запад-ю-восток & $\sim 50$ \\
\hline $2006-10-19$ & 64.1 & 148.9 & 5.2 & 7 & эллипс & с-запад-ю-восток & 220 \\
\hline $2008-06-22$ & 67.7 & 141.3 & 6.6 & 8 & эллипс & с-восток-ю-запад & 300 \\
\hline $2013-01-20$ & 64.9 & 146.7 & 5.7 & $7-8$ & эллипс & с-запад-ю-восток & 160 \\
\hline $2013-02-14$ & 67.6 & 142.5 & 6.9 & 9 & эллипс & с-восток-ю-запад & 500 \\
\hline
\end{tabular}

Таким образом, в пределах Яно-Индигирского сегмента в условиях транспрессии (сжатие со сдвигом) имеет место определенная динамическая обстановка, инициированная взаимодействием фронтальных структур зон контактного сопряжения Евразийской и Североамериканской литосферных плит. Подобные условия возможны, если при сближении литосферных плит роль активного индентора выполнял Колымо-Омолонский блок, находящийся во фронтальной части Североамериканской плиты. Результат такого воздействия проявился в формировании перед фронтальной частью индентора расходящихся северо-западных (левых) и юго-восточных (правых) сдвигов, формирующих на своих окончаниях сейсмогенерирующие зоны взбросов и надвигов, обладающих максимальным сейсмическим потенциалом.

Индигиро-Колымский (Охотский) сегмент является северным фрагментом Охотоморской коровой плиты и соответствует одноименому террейну. Он располагается к востоку от Южного сектора Верхоянского складчато-надвигового пояса, от которого отделен Билякчанским разломом северо-восточного простирания. Фундамент Охотского террейна сложен архейскими и раннепротерозойскими кристаллическими сланцами и гнейсами гранулитовой и амфиболитовой фаций метаморфизма (Гусев, 1979; Парфенов и др., 2001). Большая часть террейна перекрыта полого залегающими континентальными вулканитами ОхотскоЧукотского пояса. 
Пространственное распределение сейсмичности позволяет выделить в пределах сегмента зоны повышенной сейсмотектонической активности, где основную роль играют активные разломы и проявления сейсмичности. Инструментальные сейсмологические данные и структурно-тектонические исследования позволяют выделить здесь три активные зоны, где сейсмичность сгруппирована в протяженные диффузные полосы, приуроченные к зонам динамического влияния разломов, ограничивающих Охотский блок с запада, северо-востока и юга.

В первой из них, землетрясения концентрируются вдоль Кетандино-Ульбейской системы сдвигов субдолготной ориентации. Фокальные механизмы землетрясений, возникших здесь в 1977, 1984 и 1986 гг., имели восток-северо-восточную ориентацию напряжений сжатия и правосдвиговые смещения в их очагах. Вторая полоса сейсмичности приурочена к Индигиро-Колымской системе разломов северо-западного простирания. Большинство крупных сейсмических событий в 1974-1992 гг. произошло в зонах влияния разломов: Улахан и ЧайЮреинский, при этом кинематика движений в очагах землетрясений по данным фокальных механизмов соответствовала левым сдвигам, а сжимающие усилия действовали в северовосточном направлении (Имаев и др., 2000; Козьмин и др., 2001).

Третья, относится к зоне влияния близширотного Челомджа-Ямского левого сдвига с взбросовой компонентой. Механизм землетрясения 2001 г., эпицентр которого отмечен в плоскости сместителя рассматриваемого разрыва, также соответствовал левобоковым перемещениям в его очаге. Восточный фланг этого разлома сечет Ланково-Омолонский правый сдвиг северо-восточного простирания, следящийся, как и Челомджа-Ямский дизъюнктив, параллельно береговой линии Охотского моря. С юга к ним примыкает субширотная СевероОхотоморская система разломов, развитая в прибрежной части Охотского моря между полуостровами Лисянского и Пьягина. Названные системы разрывных нарушений отчетливо выделяются в геофизических полях. Наиболее мобильна северо-восточная граница этого блока, находящаяся в зоне контакта между Североамериканской и Охотоморской плитами и принадлежащая юго-восточному флангу сейсмотектонической зоны Черского.

Меньший уровень сейсмичности отмечен на западной границе блока в КетандиноУльбейской зоне. Повышенная плотность землетрясений фиксируется также на южной границе, где скопление эпицентров землетрясений наблюдается вдоль побережья Охотского моря от г. Охотска до пос. Палана на западном берегу Камчатки и в прибрежной к нему северной части ложа Охотского моря, совпадая по простиранию с древней сейсмофокальной зоной. Все сейсмические события Охотского блока возникают на глубине до 30 км в пределах земной коры (Имаев и др., 2000; Козьмин и др., 2001). 
Совместный анализ параметров фокальных механизмов сильных землетрясений и морфо-кинематических характеристик активных разломов, развитых в пределах ИндигироКолымского сегмента, указывает на широкое развитие здесь горизонтальных движений в виде крупных сдвиговых систем (табл. 5.1). При этом вертикальные подвижки (взбросы, надвиги и сбросы) имеют соподчиненное значение. Наиболее ярко горизонтальные смещения представлены эшелонированной системой левых сдвигов на северо-восточной границе блока. Среди них наиболее активным является разлом Улахан.

Южная часть блока, охватывающая акваторию Охотского моря, представляет жесткое ядро Охотоморской плиты, которое фактически асейсмично. Краевые части этого блока являются зонами высокой тектонической и сейсмической активности (Камчатка, Курилы, Сахалин и др.). Исключение составляет «асейсмическое окно» между северным сектором Сахалина и Кетандино-Ульбейской зоной в Приохотье, где практически отсутствуют местные землетрясения.

Таким образом, выявленная структурная организация главных сейсмогенерирующих зон и динамика очаговых областей сильных землетрясений Яно-Индигирского и ИндигироКолымского (Охотского) сегментов позволяют представить региональную структурнодинамическую модель сейсмотектонической зоны Черского. Активные тектонические структуры системы Черского развиваются в обстановке транспрессии (сжатия со сдвигом), обусловленной взаимодействием сближающихся Евразийской и Североамериканской литосферных плит, движущихся друг к другу с разными скоростям (Грачев, 1996; Имаев и др., 2000; Козьмин и др., 2001). Результатом северо-восточного давления на Евразийскую плиту со стороны Североамериканской плиты стало формирование перед фронтальной частью Колымо-Омолонского блока (индентора) расходящихся северо-западных левых и юго-восточных правых сдвигов, способствующих появлению на своих окончаниях поперечных взбросов и надвигов (рис. 5.9).

Указанные особенности современной геодинамики сейсмотектонической зоны Черского отражаются в структуре эпицентральных полей местных землетрясений. На участке наибольшего горизонтального сжатия со стороны Колымо-Омолонского инденторасупертеррейна наблюдается максимум сейсмических проявлений в виде Андрей-Тасского сгущения эпицентров землетрясений и продолжающейся от него к юго-западу полосы эпицентров вплоть до р. Адычи (рис. 5.8, 5.9). Такие же скопления подземных толчков фиксируются по обе стороны от Андрей-Тасского максимума на периферии зоны Черского на участках выжимания горных масс к северу (максимум хр. Полоусного) и юго-востоку (Верхненерский максимум). При этом наибольшим сейсмическим потенциалом будет обладать зона блока Андрей-Тас, куда направлены основные тектонические «усилия» со стороны Колымо- 
Омолонского супертеррейна, расположенного во фронтальной части Североамериканской плиты. Его генеральное северо-восточное направление (азимут 50-85²) совпадает с ориентацией большой оси эллипсов-изосейст, которые были установлены по данным наблюдений макросейсмических эффектов на земной поверхности при Уяндинском, Андрей-Тасском и Илин-Тасском землетрясениях (Имаева и др., 2011).

Следует отметить, что закономерное развитие разломов противоположной кинематики, расходящихся в разные стороны от индентора (одновременное развитие правых и левых сдвигов), типично для многих коллизионных зон и было детально изучено на структурах, возникающих при деформации горизонтального (латерального) выжимания в АльпийскоГималайском поясе (Имаев и др., 2009; Имаева и др., 2009; Козьмин, 1984). При этом отмечалось, что на участках коллизии литосферных плит, подвергающихся горизонтальному сжатию, материал может выжиматься по латерали вдоль орогенного пояса в места ослабленного сжатия. В результате сгруживания выжатых масс коры формируются раздувы орогенных поясов и поперечные складчатые зоны. Не исключено, что утонение земной коры, установленное под всей системой хребтов Черского, западнее местоположения системы МомоСеленняхских впадин (Суворов, Корнилова, 1986; Fujita et al., 2009), своим происхождением обязано процессам растяжения, происходящим в результате вертикального выжимания вещества и дальнейшего перемещения отдельных пластин (блоков) в противоположном направлении друг от друга (рис. 5.11).

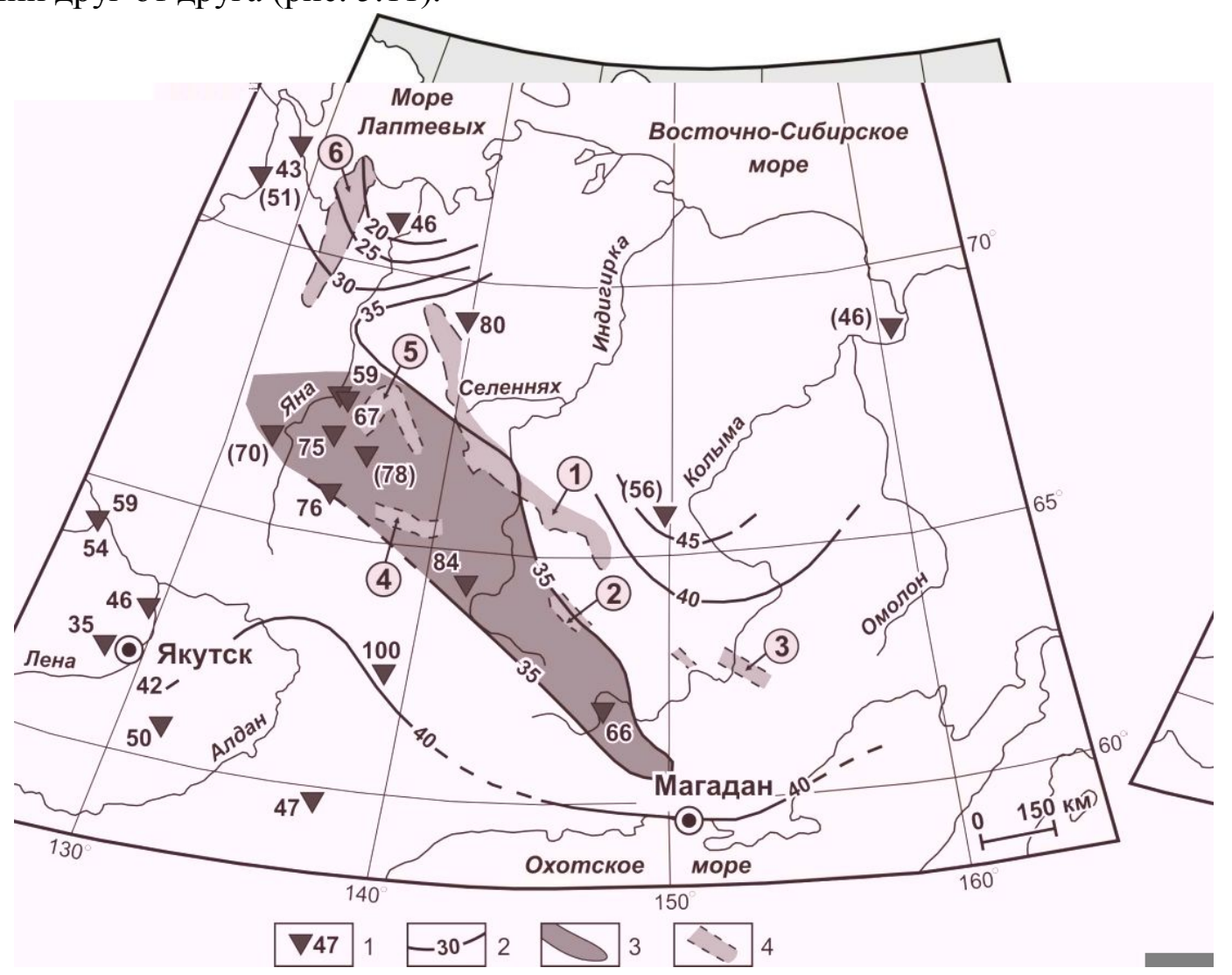

Рис. 5.11. Схема мощности земной коры Верхояно-Колымской системы мезозоид (no (Fujita et al., 2009; Mackey et al., 2007)

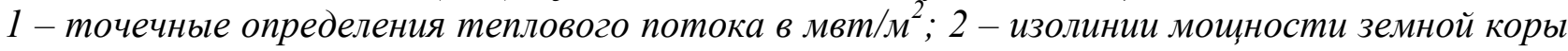
в км; 3 - область утонения земной коры; 4 - кайнозойской впадины (название в кружках): 1 - Момо-Селеняхские; 2 - Верхненерская; 3 - Сеймчано-Буюндинская; 4 - Верхнеадечанская; 5 - Туостахская; 6-Омолойская 
Подобная динамическая ситуация наблюдается в Яно-Индигирском сегменте сейсмотектонической зоны Черского на участке между реками Яна и Индигирка (рис. 5.9). Недостаток пространства в районе среднего течения р. Индигирки подчеркивается сужением разрывных структур в этом месте, а к северу и югу от шейки, разломы расходятся с заметным расширением деформируемого пространства. Отдельные пластины выдвинуты в направлении хр. Полоусный и кряжа Кулар на север и северо-запад, а их взаимоотношение со структурами субширотной ориентации хр. Полоусного выражается разнонаправленным типом смещения по ограничениям блоков (правые и левые сдвиги) и указывает на тенденцию выдавливания материала. На рис. 5.12 отчетливо дешифрируется первоначальное выжимание гранитоидов Буордахского массива и их направление дальнейшего перемещения в северном и северо-западном направлениях.

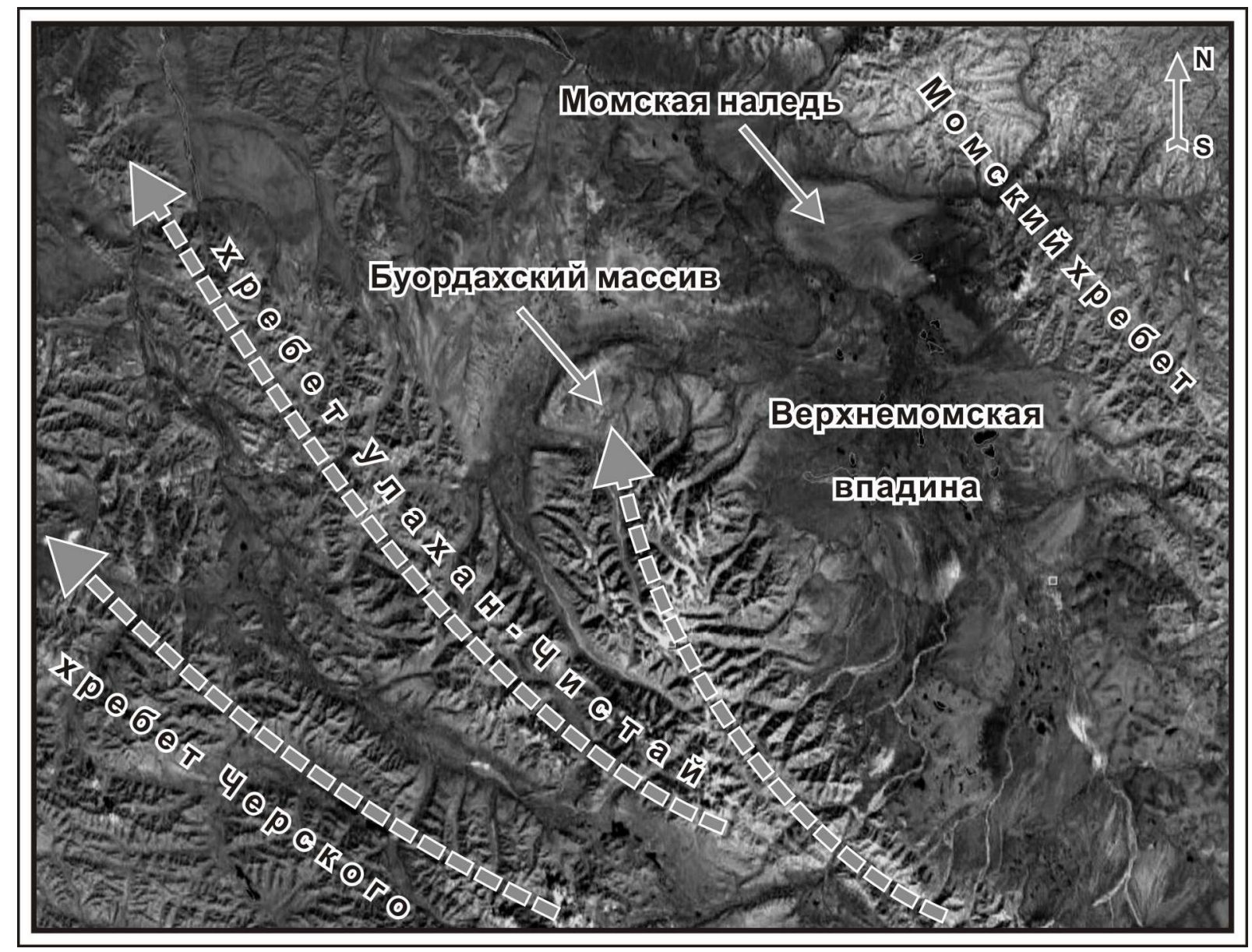

Рис. 5.12. Структурно-кинематический план и направления перемещения вещества массива Буордах (хребет Улахан-Чистай)

Под воздействием сжимающих усилий Охотоморская плита выталкивается к юговостоку и востоку (Fujita et al., 2009; Mackey et al., 2007), способствуя конвергенции Североамериканской и Евразийской плит с развитием левосторонних движений по разломам в северо-западном сегменте зоны Черского и заливе Шелехова Охотского моря, а также правосто- 
ронних перемещений в бассейнах рек Кетанда, Ульбея и Охота в Северном Приохотье и на о. Сахалин. Полученные результаты детальных сейсмотектонических исследований и структурно-динамические модели главных сейсмогенерирующих зон ААСП могут являться базовой основой для проведения общего сейсмического районирования, палеогеодинамических реконструкций и поиска полезных ископаемых.

\section{3. СОВРЕМЕННАЯ ГЕОДИНАМИКА}

Принципиальная схема современной геодинамики северо-востока Азии приведена на рис. 5.13, где показано пространственное распределение эпицентров землетрясений, главные тектонические элементы - плиты-гиганты, закономерно взаимодействующие друг с другом, и проведены границы этих литосферных плит.

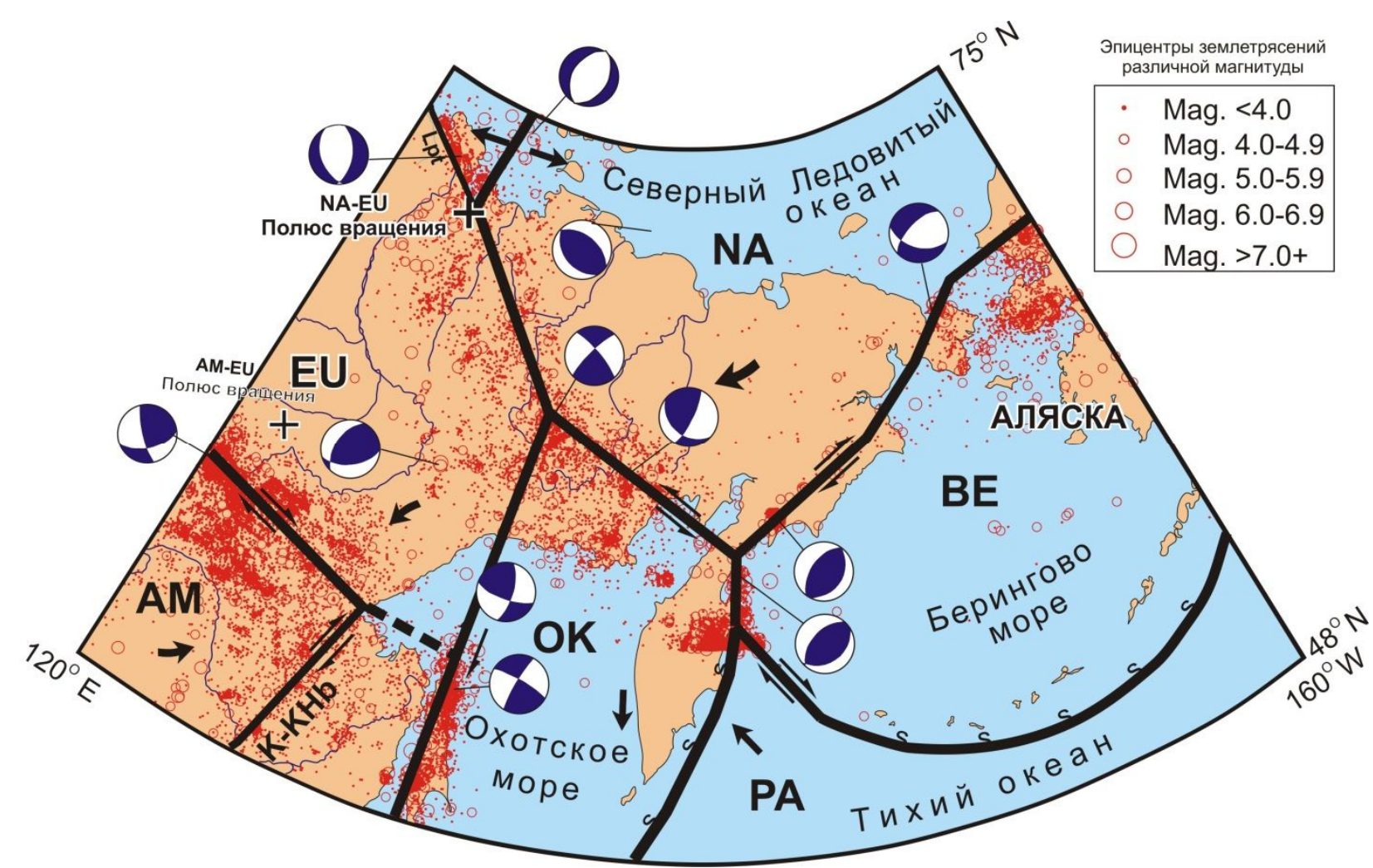

Рис. 5.13. Схема современной геодинамики северо-востока Азии

NA - Североамериканская плита, АM - Амурская плита, ОК - Охотоморская плита, ВE Беринговоморская плита, EU - Евразийская плита, PA - Тихоокеанская плита, (по (Масkеу et al., 1997; Имаев и др., 2000, с дополнениями))

Сейсмотектоническая позиция взаимодействия отдельных сегментов границы Североамериканской и Евразийской литосферных плит обусловлена характером напряженнодеформированного состояния верхних частей коры. При этом полюс вращения между плитами располагается на севере Верхоянского хребта, несколько южнее широты губы Буор-Хая 
моря Лаптевых, хотя его точное местоположение изменяется в зависимости от используемого метода определения полюса (Cook et al., 1986; DeMets et al., 1990; Kogan et al., 2000; Sella et al., 2002).

Такое расположение согласуется с наблюдаемым изменением фокальных механизмов от растяжения в губе Буор-Хая до сжатия и анализом геолого-геофизических данных проведенных в пределах сейсмотектонической зоне Черского (Имаев и др., 1990, 2000). Согласно дополнительным исследованиям, проведенным в последнее время (Rowley, Lottes, 1988; Gaina et al., 2002), можно предположить, что полюс вращения перемещался по северовосточной части России в кайнозое, с чередованием режима напряжения от растяжения к сжатию.

Результаты сейсмотектонического анализа показывают, что хребет Черского в данное время находится в режиме транспрессии (Cook et al., 1986; Имаев и др., 1990; Fujita et al., 1990; Riegel et al., 1993). Анализ геодинамических условий в сейсмическом поясе Черского показывает, что они многократно менялись в течение кайнозоя с чередованием растяжения и сжатия (Савостин, Драчев, 1988). Структура Момских кайнозойских впадин, соответсвовавшая формированию на этой территории Момского рифта, по-видимому, существовала на этой территории во время эпизода, когда полюс вращения между Северной Америкой и Евразией располагался около побережья Охотского моря (Грачев, 1996), помещая континентальную северо-восточную Азию в условия растяжения. Это растяжение кончилось около 0.5 млн. лет назад, когда полюс вращения мигрировал на северо-запад, к своему нынешнему положению около моря Лаптевых (Cook et al., 1986; Kogan et al., 2000), помещая хребет Черского в условия сжатия, но с сохранившимися остатками вулканической активности и высокого теплового потока (Имаев и др., 1990).

Таким образом, в пределах ААСП и АСТБСП наблюдается закономерная смена геодинамических режимов и сейсмотектонических зон или сегментов. Так, в ААСП наблюдается зона растяжения земной коры - хребет Гаккеля, промежуточная зона - смешанное поле тектонических напряжений (режим транстенсии - растяжение со сдвигом) на шельфе моря Лаптевых и в Хараулахской зоне, зона сжатия со скольжением (режим транспрессии), вызванное сближением плит в северо-восточном направлении - зона хребта Черского. В БСП сжатие в сдвиговых зонах Алтая, Саян и Тувы сменяется растяжением, наблюдаемым в Байкальской рифтовой зоне, далее на восток сменяется структурами сжатия со скольжением в восточной части - в ОСЗ. Кроме того, различные формы «поведения» сейсмичности (распределение в пространстве, сейсмический режим, характер фокальных механизмов землетрясений), совместно со сведениями по «живой» тектонике и структурной геологии, GPS 
данными позволили рассмотреть особенности сейсмического процесса отдельных структур и блоков, происходящие на исследуемой территории.

Сейсмический пояс Черского представляет собой зону интенсивной деформации между Североамериканской и Евразийской плитами. Она изменяется от растяжения в море Лаптевых до транспрессии в хребте Черского и к югу от него. Зона деформации ограничена двумя главными системами разломов - системой разломов Улахан на севере и несколько менее ярко выраженной Кетандинской системой на западе. Характер фокальных механизмов указывает на левосторонние сдвиговые движения по разлому Улахани связанным с ним разломом с преобладающим правосторонним движением по Кетандинскому разлому, что хорошо согласуется с юго-восточной экструзией Охотской плиты.

Можно предполагать, что при общем конвергентном движении Североамериканской и Евразийской плит навстречу друг другу в субширотном направлении в пределах большей части континентального отрезка взаимодействия этих плит формируется устойчивый сегмент этой границы - сейсмотектоническая зона Черского, главным типом сейсмогенной деформации в котором - левые продольные сдвиги (Улахан, Чай-Юреинский, Арга-Тасский, Илинь-Тасский и др.) и параллельные им надвиги и взбросы (Мятисский, Адыча-Тарынский и др.).

Охотоморская плита испытывающая сжатие сближающимися плитами, как бы выталкивается к югу, в направлении Тихоокеанской зоны субдукции. Примечательно, что на севере, в районе побережья моря Лаптевых, и на юге, на острие угла, образуемого Охотоморской, Евразийской и Североамериканской плитами формируются точки тройного сочленения, обозначающие существенное повышение уровня сейсмической активности в них. Так, для северной части характерно отклонение фоновой сейсмичности на северо-запад вдоль границы Лаптевоморской микроплиты. Именно здесь, совпадая с точкой тройного сочленения и полюсом вращения, рассчитанным для Евразийской и Североамериканской плит, устанавливаются палеосейсмодислокациии связанные с Булунскими землетрясениями 1927-1928 гг.

Такое же повышение уровня сейсмической опасности характерно и для Оймяконской точки тройного сочленения, к которой тяготеет Артыкское землетрясение 1971 г. (М>7.0). Что касается южной границы Евразийской и Амурской плиты, то в восточной части можно допустить отделение от нее небольшого Хабаровского-Корейского блока (или микроплиты), которая ограничивается системой сдвиговых разломов Тян-Лу. Рассчитанный полюс вращения Амурской и Евразийской плит пространственно тяготеет к междуречью Алдана и Вилюя.

В конечном итоге материалы по сейсмотектонике и новейшей геодинамике сейсмических поясов на северо-востоке Азии дают возможность весьма успешно вести прогноз возможных сценариев поведения сейсмической активности территории, предполагая место и 
предельную величину возможной сейсмической катастрофы. Определение структурной позиции позволяет предполагать наиболее опасные направления выделения сейсмической энергии и снижать степень риска расположения потенциальных народнохозяйственных объектов.

Вместе с тем вся рассматриваемая территория все еще представляет собой весьма сложный и малоосвоенный регион России, где происходят активные деформации между несколькими тектоническими плитами. Для того чтобы лучше понять геодинамическую обстановку формирования сейсмогенных разломов и сейсмотектоническую природу региональной сейсмичности, необходимо использовать многосторонний подход, включающий многочисленные базы данных по сейсмичности, геофизике, геоморфологии, геологии и т.д. 


\section{ЗАКЛЮЧЕНИЕ}

Из анализа всего имеющегося материала можно утверждать, что континентальная окраина Восточной Сибири - одно из немногих оставшихся на Земле мест, где современная тектоническая обстановка изучена все еще довольно поверхностно и слабо. После обобщения всех материалов сейсмологических наблюдений над землетрясениями, фиксируемыми здесь сейсмическими станциями, принадлежащими Якутской, Магаданской и Байкальской опытно-методическим сейсмологическим партиям, и составления сводной карты сейсмичности, использующей данные сейсмических каталогов всех подразделений на востоке России, удалось установить более сложную геодинамическую обстановку взаимодействия здесь трех главных литосферных плит - Североамериканской, Тихоокеанской и Евразийской, и четырех коровых плит (Сибирской, Амурской, Охотоморской и Лаптевоморской), где основные деформации связаны с процессами перемещений происходящих в пределах границ корамантия. Тектонические границы и движения всех этих плит подтверждаются детальным картированием активных разломов (тех, с которыми связываются движения, приводящие к землетрясениям), палеосейсмодислокаций, фокальными механизмами и геоморфологическими наблюдениями. Проведенные комплексные геолого-геофизические и сейсмологические исследования позволили установить на северо-востоке Евразии два протяженных сейсмических пояса - Арктико-Азиатский и Южно-Сибирский, состоящих из отдельных сегментов. ЮжноСибирский сейсмический пояс соединяет сейсмичность Алтае-Саянско-Тувинского сегментов, Байкальской рифтовой зоны, Олекмо-Становой зоны с сейсмичностью Охотского моря. Проявления сейсмотектонических процессов в Лаптевоморском, Хараулахском, Черского и Охотоморском сегментах объединяет сейсмичность Северно Ледовитого и Тихого океанов (Арктико-Азиатский сейсмический пояс). Пояса возникли в результате сближения крупных литосферных плит - Евразийской, Североамериканской и Амурской - и представляют собой их активные границы. Взаимодействие континентальных участков этих плит охватывает широкую полосу (до нескольких сотен километров), в пределах которой смещение отдельных неотектонических блоков и связанное с ними выделение сейсмической энергии происходят по серии активизированных разломов определенного парагенезиса (Fujita et al., 2010; Riegel et al., 1993; Имаев и др., 1990, 2000; Mackey et al., 2003, 2010).

Каждый из выделенных сейсмических поясов обладает своими специфическими чертами строения и особенностями пространственного проявления землетрясений внутри них и в конечном итоге определяет особенности проявления сейсмичности в каждом конкретном месте самих поясов и прилегающих к ним районам.

Подводя итог сейсмотектонических исследований, можно констатировать: 
1 - карта сейсмотектоники Восточной Сибири является первым наглядным примером построения карты нового поколения (электронная база данных сейсмотектонических параметров), которая объединяет элементы геолого-геофизических параметров и сейсмичности и объясняет особенности современной геодинамики (а соответственно и сейсмическую опасность) региона;

2 - построение таких карт позволяет перейти к созданию карт детального сейсмического районирования отдельных частей активно промышленно - осваиваемых районов Восточной Сибири и обоснованно установить уровень сейсмической угрозы тех или иных районов проживания коренного населения Сибири. Данный подход позволит приступить к новому этапу исследований проблемы сейсмобезопасности, а созданные региональные сейсмогеодинамические модели будут способствовать уточнению исходного сейсмического балла существующих нормативных карт общего и детального сейсмического районирования;

3 - карта должна использоваться в органах исполнительной власти отдельных районов, комитетах по чрезвычайным ситуациям (ГКЧС) с целью владения информацией о возможных негативных влияниях сильных местных землетрясений, определения балла сейсмической угрозы конкретных населенных пунктов.

Данное научное исследование выполнено при поддержке интеграционного проекта СО РАН и гранта Министерства Науки и Образования РФ (Госуд. задание № $5.1771 .2014 / K)$.

Сбор, обработка фактических данных и сейсмотектонические построения для Арктического сегмента Восточной Сибири выполнены при поддержке Гранта РНФ-1517-20000. 


\section{ЛИТЕРАТУРА}

Аветисов Г.П. Сейсмоактивные зоны Арктики. - Л.: ВНИИ Океанологии, 1996. $185 \mathrm{c}$.

Аветисов Г.П., Гусева Ю.В. Глубинное строение района дельты Лены по сейсмологическим данным // Сов. Геология, 1991. № 4. С. 73-81.

Аветисов Г.П. Сейсмоактивные зоны Арктики. - Санкт-Петербург: ВНИИ Океанологии, 1996. - 185 с.

Аплонов С.В. Геодинамика. Учебник. - СПб: Изд-во С.-ПбГУ, 2001. - 360 с.

Аржанников С.Г., Зеленков П.Я. Сильные палеоземлетрясения хребта Академика Обручева (Восточная Тува) // Сейсмичность и сейсмическое районирование Северной Евразии. - М.: ОИФЗ РАН, 1995. ВЫп. 2/3. С. 323-330.

Аржанников С.Г. Сейсмотектоника Восточно-Тувинского нагорья. Автореф. дис. канд. г-м. наук. - Иркутск: Институт земной коры СО РАН, 1998. - 16 с.

Аржанников С.Г. Палеосейсмодислокации в зоне влияния Оттугтайгино-Азасского разлома (Восточная Тува) // Геология и Геофизика, 2000.Т. 41. № 11. С. 1501-1510.

Аржанникова А.В., Аржанников С.Г. Проявления новейших тектонических деформаций на юге Сибирской платформы // Геология и геофизика, 2005. Т. 46. № 3. С. 273279.

Богданович К.И., Карк И.М., Корольков В.Я., Мушкетов Д.И. Землетрясение в северных цепях Тянь-Шаня 22 декабря 1910 г. // Труды Геол. ком, 1914. Вып. 89. - 270 с.

Бочаров Г.В., Замараев Н.Н. Геодезические измерения на геодинамических полигонах Южной Якутии // Геодезия и картография, 1991. № 3. С. 30-34.

Важенин Б.П. Палеосейсмодислокации в сейсмическом поясе Черского // Сейсмологические и петрофизические исследования на северо-востоке России. - Магадан: СВКНИИ ДВО РАН, 1992. С. 79-102.

Важенин Б.П. Принципы, методы и результаты палеосейсмогеологических исследований на Северо-Востоке России. - Магадан: СВКНИИ ДВО РАН, 2000. - 205 с.

Ваков А.В. Геометрические параметры и магнитуда очагов землетрясений при различных типах подвижек // Вопр. Инженерной сейсмологии. Вып. 33. - М.: Наука, 1992. C. $40-53$.

Введенская А.В., Балакина Л.М. Методика и результаты определения напряжений, действующих в очагах землетрясений Прибайкалья и Монголии // Бюл. Совета по сейсмол. № 5. С. 73-84.

Вдовин В.В., Зеленков П.Я. Сейсмогенные формы рельефа Тувы и Западного Саяна // Закономерности развития рельефа Северной Азии. - Новосибирск: Наука, 1982. С. 99106.

Геодаков А.Р., Овсюченко А.Н., Платонова С.Г., Рогожин Е.А. Материалы предварительного изучения сильного землетрясения 2003 г. на Горном Алтае. Электронный научно-информационный журнал «Вестник отделения наук о Земле РАН», 2003. № 1(21). С. 123.

Гитис В.Г., Миронов М.А., Бунэ В.И. и др. Прогноз Мmax землетрясений на основе аппроксимации интервальных экспертных оценок // Физика Земли, 1986. № 4. С. 24-31.

Гоюй Д. Краткий обзор последних исследований в палеосейсмологии (перевод с китайского) // Шицянь дичжень юй дисыцзы дичжи вэньцзи. Сб. ст., 1982. С. 3-7. 
Грамберг И.С., Деменицкая Р.М., Секретов С.Б. Система рифтогенных грабенов шельфа моря Лаптевых как недостающего звена рифтового пояса хребта Гаккеля // Докл. АН СССР, 1990. Т. 311, № 3. С. 89-94.

Грачев А.Ф., Деменицкая Р.М., Карасик А.М. Проблемы связи Момского континентального рифта со структурой срединно-океанического хребта Гаккеля // Геофизические методы разведки в Арктике. - Л.: НИИГА, 1973. Вып. 8. С. 56-75.

Грачев А.Ф. Основные проблемы новейшей тектоники и геодинамики Северной Евразии // Физика Земли, 1996. № 12. С. 5-36.

Гусев Г.С. Складчатые структуры и разломы Верхояно-Колымской системы мезозоид. - М.: Наука, 1979. - 207 с.

Гусев Г.С., Имаева Л.П., Акатова К.Н. Зонирование геодинамической активности неотектонических структур для целей общего сейсмического районирования территории Российской Федерации - ОСР-2012 // Труды VII Общероссийской конференции «Перспективы развития инженерных изысканий в строительстве в Российской Федерации», г. Москва 15-16 декабря 2011 г. С. 207-208.

Гусев Г.С., Имаева Л.П. Новейшая и современная тектоническая (геодинамическая) активность территории России // Разведка и охрана недр, 2014. № 12. С. 29-35.

Гусев Г.С., Имаева Л.П., Имаев В.С. Анализ новейших (позднекайнозойских) структур; принципы выделения и параметризации доменов для создания карт сейсмического районирования нового поколения (ОСР-2012). Тезисы докладов Всероссийского совещания с участием приглашенных исследователей из других стран. - Иркутск, 11-16 августа 2014. С. 47.

Зоненшайн Л.П., Савостин Л.А. Введение в геодинамику. - М.: Недра, 1979. - 311 с.

Еманов А.Ф., Еманов А.А., Лескова Е.В., Селезнев В.С., Филина Е.Г. Тувинское землетрясение 27.12.2011 г., ML=6.7 и его афтершоки // Вестник ОНЗ PAН: Электронный научно-информационный журнал «Вестник», 2012. Т. 4.

Имаев В.С., Имаева Л.П., Козьмин Б.М. Активные разломы и сейсмотектоника Северо-Восточной Якутии. - Якутск: ЯНЦ СО АН СССР, 1990. - 138 с.

Имаев В.С., Имаева Л.П., Козьмин Б.М., Фуджита К. Активные разломы и современная геодинамика сейсмических поясов Якутии // Геотектоника, 1994. № 2. С. 89-97.

Имаев В.С., Имаева Л.П., Козьмин Б.М., Макки К., Фуджита К. Сейсмотектонические процессы на границе литосферных плит северо-востока Азии и Аляски // Тихоокеанская геология, 1998. Т. 17. № 2. С. 3-17.

Имаев В.С., Имаева Л.П., Козьмин Б.М., Сурнин А.А. Сейсмоактивные сдвигигенераторы современных впадин «pull-apart» на Северо-Востоке Азии // Тектоника, геодинамика и процессы магматизма и метаморфизма. Материалы XXXII Тектонического совещания. - М.: ГЕОС, 1999. Т. 1. С. 283-285.

Имаев В.С., Имаева Л.П., Козьмин Б.М., Гунбина Л.В., Макки К., Фуджита К., Сейсмичность и современные границы плит и блоков Северо-Восточной Азии // Геотектоника, 2000. № 4. C. 44-51.

Имаев В.С., Имаева Л.П., Козьмин Б.М. Сейсмотектоника Якутии. - М.: ГЕОС, 2000. - 227 c.

Имаев В.С., Имаева Л.П., Козьмин Б.М. «Сейсмическое районирование Южной Якутии» // Отечественная геология, 2001. № 5. С. 49-53.

Имаев В.С., Барышников Г.Я., Лузгин Б.Н., Осьмушкин В.С., Имаева Л.П., Барышникова О.Н. Архитектура сейсмоопасных зон Алтая. - Барнаул: Изд-во Алт. ГУ, 2007. $234 \mathrm{c}$. 
Имаев В.С., Имаева Л.П., Маккей К.Г. и др. Геодинамика отдельных сегментов литосферных плит на северо-востоке Азии // Геофизические исследования, 2009. Т. 10. № 1. C. 5-17.

Имаев В.С., Стром А.Л., Чипизубов А.В, Смекалин О.П., Имаева Л.П., Лободенко И.Ю. Перспективы использования лазерного сканирования при проведении палеосейсмологических исследований в Сибири // Геотектоника, 2013. № 3. С. 78-86.

Имаева Л.П., Имаев В.С., Козьмин Б.М. «Живые» разломы и сейсмичность Токинского Становика // Отечественная геология, 2000. № 5. С. 53-57.

Имаева Л.П., Имаев В.С., Козьмин Б.М. и др. Сейсмическая опасность и современная геодинамика Токинского Становика. - Нерюнгри: Изд-во Технического ин-та (Ф) ЯГУ, 2009. - 167 c.

Имаева Л.П., Имаев В.С., Козьмин Б.М. Сейсмотектонический анализ ЯноИндигирского сегмента зоны Черского // Физика земли, 2010. № 12. С. 79-86.

Имаева Л.П., Имаев В.С., Козьмин Б.М. Сейсмотектонический анализ ЯноИндигирского сегмента зоны Черского // Физика земли, 2011. № 12. С. 1-14.

Имаева Л.П., Козьмин Б.М., Имаев В.С. Динамика очаговых зон сильных землетрясений северо-восточного фланга Момо-Селенняхских впадин // Отечественная геология, 2011. № 5. C. 113-119.

Имаева Л.П., Имаев В.С., Козьмин Б.М., Смекалин О.П. Сейсмогеодинамика Алдано-Станового блока // Тихоокеанская геология, 2012. Т. 31. № 1. С. 5-17.

Имаева Л.П., Козьмин Б.М., Имаев В.С. Динамика сейсмогенных структур Индигиро-Колымского (Охотского) сегмента зоны хр. Черского // Отечественная геология, 2012. № 5. C. 55-61.

Имаева Л.П., Имаев В.С., Козьмин Б.М., Смекалин О.П. Закономерности сейсмотектонической деструкции сейсмического пояса Черского (СПЧ) // Материалы Всероссийского совещания «Современная геодинамика Центральной Азии и опасные природные процессы: результаты исследований на количественной основе». - Иркутск: ИЗК СО РАН, 2012. T. 2. C. $28-31$.

Имаева Л.П., Мельникова В.И., Имаев В.С. Сейсмотектоническая деструкция северо-восточного фланга Байкальской рифтовой зоны // Доклады академий наук, 2012. Т. 443. № 4. C. 492-494.

Имаева Л.П., Козьмин Б.М., Имаев В.С. Активизация сейсмотектонических процессов на западе Олекмо-Становой сейсмической зоны // Отечественная геология, 2013. № 6. C. 37-43.

Имаева Л.П., Козьмин Б.М., Имаев В.С. Активизация сейсмотектонических процессов на западе Олекмо-Становой сейсмической зоны // Отечественная геология, 2014. № 1. C. $48-54$.

Имаева Л.П., Козьмин Б.М., Имаев В.С. Особенности сейсмотектонических процессов в зоне Илинь-Тасского (Абыйского) землетрясения 14 февраля 2013 года (СевероВосточная Якутия) // Отечественная геология, 2014. № 5. С. 33-38.

Карасик А.М. Магнитные аномалии хребта Гаккеля и происхождение Евразийского бассейна Северного Ледовитого океана // Геофизические методы разведки в Арктике, 1968. Вып. 6. С. 8-19.

Козьмин Б.М. Сейсмические пояса Якутии и механизмы очагов их землетрясений. - М.: Наука, 1984. - 125 с. 
Козьмин Б.М., Имаев В.С., Имаева Л.П. Сейсмичность и современная геодинамика // Тектоника, геодинамика и металлогения территории республики Саха (Якутия). - М.: Наука, 2001. С. 33-67.

Комплект карт общего сейсмического районирования территории Российской Федерации - ОСР-97. Масштаб 1:8000000. Объяснительная записка и список городов и населенных пунктов, расположенных в сейсмоопасных районах. - М., 1999.

Копп М.Л. Горизонтальное выдавливание при сжатии орогенических поясов // Бюл. МОИП. Отд. геол., 1981. Т. 56. № 2. С. 14-28.

Копп М.Л. Структуры латерального выжимания в Альпийско-Гималайском коллизионном поясе // Труды ГИН РАН. - М.: Научный мир, 1997. Вып. 506. - 314 с.

Логачев Н.А., Шерман С.И., Леви К.Г. Геодинамическая активность литосферы Азии: основы анализа и принципы картирования // Геодинамика и развитие тектоносферы: Труды Тектонического совещания. - М.: МТК, 1991, С. 31-39.

Макаров В.И. О региональных особенностях новейшей геодинамики платформенных территорий в связи с оценкой их тектонической активности // Недра Поволжья и Прикаспия, 1996. Спец. вып. 13. С. 53-60.

Малышев Ю.Ф., Романовский И.П., Подгорный Б.Я., Каплун В.Б., Горнов П.Ю. Глубинное строение структур ограничения литосферных плит Восточной Азии. Тектоника, глубинное строение и минерагения Востока Азии. V Косыгинские чтения. Материалы конференции. 24-27 январи 2006 г. - Хабаровск, 2006. С. 97-101.

Мельникова В.И. Деформационные параметры земной коры Байкальской рифтовой зоны по сейсмологическим данным / Автореф. докт. диссертации. - Иркутск, 2008. - 37 с.

Мишарина Л.А. Напряжения в земной коре в рифтовых зонах. - М.: Наука, 1967. $136 \mathrm{c}$.

Мокшанцев К.Б., Гусев Г.С., Козьмин Б.М., Третьяков Ф.Ф. Сейсмичность, современные и древние поля напряжений северо-восточной Азии в связи с проблемой Момского рифта // Континентальный рифтогенез. - М.: Сов. радио, 1977. С. 76-82.

Мушкетов И.В., Орлов А.П. Каталог землетрясений Российской империи. (Записки Русского географ. общества по общей географии, т. XXVI). - Спб.: Типограф. Императорской Академии Наук, 1893. - 583 с.

Николаев В.В., Семенов Р.М., Солоненко В.П. Сейсмогеология Монголо-Охотского линеамента. - Новосибирск: Наука, 1979. - 112 с.

Николаев В.В., Семенов Р.Ф., Семенова В.Г., Солоненко В.П. Сейсмотектоника, вулканы и сейсмическое районирование хребта Станового. - Новосибирск: Наука, 1982. $150 \mathrm{c.}$

Никонов А.А. Голоценовые и современные движения земной коры. - М.: Наука, 1977. $-240 \mathrm{c}$.

Никонов А.А. Голоценовые и современные движения земной коры: Геологогеоморфологические и сейсмотектонические вопросы. - М.: Наука, 1977. - 240 с.

Никонов А.А. Определение магнитуд и повторяемости сильных землетрясений прошлого по сейсмодислокациям (на примере зоны сочленения Памира и Тянь-Шаня) // ДАН СССР, 1980. Т. 250, № 3. С. 336-339.

Никонов А.А. Датирование сейсмотектонических подвижек и древних землетрясений с помощью радиоуглеродного анализа и археологических данных (на примере гор Средней Азии) // Доклады АН СССР, 1981. Т. 257. № 2. С. 440-444.

Никонов А.А. Активные разломы: определение и проблемы выделения // Геоэкология, 1995. № 4. С. 16-27. 
Палеосейсмология. В 2-х томах. / Ред. Дж.П. Мак-Калпин. М.: Научный Мир, 2011. $878 \mathrm{c}$.

Парфенов Л.М., Прокопьев А.В., Спектор В.Б. Рельеф земной поверхности и история его формирования // Тектоника, геодинамика и металлогения территории республики Саха (Якутия). - М.: Наука, 2001. С. 12-31.

Прокопьев А.В., Дейкуненко А.В. Деформационные структуры складчатонадвиговых поясов // Тектоника, геодинамика и металлогения территории Республики Саха (Якутия). - М.: МАИК «Наука», 2001. С. 156-198.

Разломная тектоника территории Якутской АССР. - Якутск: ЯФ СО АН СССР, 1976. $-173 \mathrm{c}$.

Радзиминович Н.А., Мельникова В.И., Козьмин Б.М., Татомир Н.В. Олдонгсинский рой землетрясений 1997-2002 гг. на северо-восточном фланге Байкальской рифтовой зоны. Геодинамика и геологические изменения в окружающей среде северных регионов. Архангельск: ИЭПС УрО РАН, 2004. № 2. С. 193-196.

Рейснер Г.И. Геологические методы оценки сейсмической опасности. М.: Недра, 1980. - 175 c.

Рейснер Г.И., Иогансон Л.И., Рейснер М.Г., Баранов Ю.Е. Типизация земной коры и современные геологические процессы. - М.: ОИФЗ РАН, 1993. - 208 с.

Рогожин Е.А., Платонова С.Г. Очаговые зоны сильных землетрясений Горного Алтая в голоцене. - М.: ОИФЗ РАН, 2002. - 130 с.

Рогожин Е.А., Овсюченко А.Н., Мараханов А.В., Бурканов Е.Е., Платонова С.Г. Тектоническая позиция и геологические проявления Алтайского землетрясения 2003 г. // Сильное землетрясение на Алтае 27 сентября 2004 г.: материалы предварительного изучения. - М.: ИФЗ РАН, 2004. С. 25-37.

Рогожин Е.А. Очерки региональной сейсмотектоники. - М.: ИФЗ РАН, 2012. - 340 с.

Савостин Л.А., Драчев С.С. Кайнозойское сжатие в районе Новосибирских островов и его связь с раскрытием Евразийского бассейна // Океанология, 1988. Т. 28. № 5. С. 775781.

Сидоров В.А., Кузьмин Ю.О., Хитров А.М. Концепция «Геодинамическая безопасность освоения углеводородного потенциала недр России». - М.: ИГиРГИ, 2000.

СНиП II-7-81*. Строительство в сейсмических районах. - М.: ГУП ЦПП Госстроя России, 2000.

Смекалин О.П., Имаев В.С., Чипизубов А.В., Семенов Р.М. Изучение сейсмогенных сбросов Кичерской структуры в разрезах канав // Тихоокеанская геология, 2007. Т. 26. № 2. С. $82-92$.

Смекалин О.П., Чипизубов А.В., Имаев В.С. Палеоземлетрясения Прибайкалья: методы и результаты датирования // Геотектоника, 2010. № 2. С. 77-96.

Солоненко В.П. Определение эпицентральных зон землетрясений по геологическим признакам // Изд. АН СССР. - Сер. геол., 1962. № 11. С. 58-74.

Солоненко В.П., Тресков А.Л., Жилкин В.М. и др. Сейсмотектоника и сейсмичность рифтовой системы Прибайкалья. - М.: Наука, 1968. - 220 с.

Солоненко В.П. Палеосейсмогеология // Изв. АН СССР. Физика Земли, 1973. № 9. С. $3-16$.

Старовойт О.Е., Чепкунас Л.С., Габсатарова И.П. Параметры землетрясения 27 сентября 2003 г. на Алтае по инструментальным данным // Электронный научноинформационный журнал «Вестник отделения наук о Земле РАН», 2003. № 1(21). 
Строительные нормы и правила. Строительство в сейсмических районах. СНиП ІІ-781*, 1981.

Строительные нормы и правила. Строительство в сейсмических районах. СНиП II-7$81 *, 2000$.

Стром А. Л. Сопоставление параметров современных и палеосейсмотектонических дислокаций // Физика Земли, 1993. № 9. С. 38-42.

Стром А.Л., Никонов А.А. Корреляция между параметрами сейсмодислокаций и магнитудами землетрясений // Физика Земли, 1997. № 12. С. 55-67.

Суворов В.Д., Корнилова 3.А. Глубинное строение Алданского щита по данным сейсмологии близких землетрясений // Геология и геофизика, 1985. № 2. С. 86-93.

Суворов В.Д., Корнилова 3.А. Мощность земной коры на юго-востоке ВерхояноКолымской складчатой области // Тихоокеан. Геология, 1986. № 4. С. 32-35.

Тектоника, геодинамика и металлогения территории республики Саха (Якутия). М.: МАИК «Наука/ Интерпериодика», 2001. - 571 с.

Тектоника Якутии / Под ред. Ю.Н. Трушкова. - Новосибирск: Наука, 1975. - 198 с.

Теркот Д.Л., Шуберт Дж. Геодинамика: геологические приложения физики сплошных сред. Ч.1. Пер. с англ.- М.: Мир, 1985. - 376 с.

Толковый словарь английских геологических терминов. - М.: Мир, 1977-1978. Т. 12.

Трифонов В.Г. Позднечетвертичный тектогенез. - М.: Наука, 1983. - 224 с.

Трифонов В.Г. Особенности развития активных разломов // Геотектоника, 1985. № 2. C. $16-26$.

Трифонов В.Г., Востриков Г.А., Кожурин А.И. и др. Неотектоника и современная геодинамика подвижных поясов. М.: Труды Геол. ин-та АН СССР, 1988. Вып. 427. 365 с.

Трифонов В.Г., Кожурин А.И., Лукина Н.В. Изучение и картирование активных разломов // Сейсмичность и сейсмическое районирование Северной Евразии. - М.: ОИФЗ РAH, 1993. Т. 1. С. 196-206.

Трифонов В.Г. Неотектоника Евразии. - М.: Научный мир, 1999. - 254 с.

Трифонов В.Г., Востриков Г.А., Трифонов Р.В., Соболева О.В. Активные разломы Евразии: геодинамический аспект // Тектонические и геодинамические феномены. - М.: Наука, 1997. С. 174-195.

Трифонов В.Г. Живые разломы земной коры // Соросовский образовательный журнал, 2001. Т. 7. № 7. С. 66-74.

Трифонов В.Г., Соболева О.В., Трифонов Р.В., Востриков Г.А. Современная геодинамика Альпийско-Гималайского коллизионного пояса // Труды ГИН РАН. Вып. 541. М.: ГЕОС, 2002. -225 c.

Трифонов В.Г., Караханян А.С. Геодинамика и история цивилизаций. - М.: Наука, 2004. $-668 \mathrm{c}$.

Уломов В.И. Об основных положениях и технических рекомендациях по созданию новой карты сейсмического районирования территории Российской Федерации // Сейсмичность и сейсмическое районирование Северной Евразии. - М.: ОИФЗ РАН, 1995. Вып. 2-3. С. 9-26.

Уломов В.И., Шумилина Л.С. Комплект новых карт общего сейсмического районирования территории Российской Федерации // Сейсмостойкое строительство. - 1998. № 4. C. 30-34.

Уломов В.И., Шумилина Л.С. Комплект карт общего сейсмического районирования территории Российской Федерации - ОСР-97. Масштаб 1:8000 000. Объяснительная за- 
писка и список городов и населенных пунктов, расположенных в сейсмоопасных районах. - М.: ОИФЗ РАН, 1999. - 57 с.

Уломов В.И., Шумилина Л.С. Проблемы сейсмического районирования территории России // Всероссийский НИИ проблем научно-технического прогресса и информации в строительстве. - М.: ВНИИНТПИ Госстроя России, 1999. - 56 с.

Уломов В.И. Актуализация общего сейсмического районирования территории Российской Федерации и создание нормативных карт следующего поколения - ОСР-2012 // Труды IX Российской национальной конференции по сейсмостойкому строительству и сейсмическому районированию (с международным участием), г. Сочи 06-09 сентября 2011 г. С. 232-235.

Уломов В.И. Актуализация нормативноого сейсмического районирования в составе единой информационной системы «Сейсмобезопасность России» // Геориск, 2011. № 6. С. 78-93.

Флоренсов Н.А., Хилько С.Д. Рельеф и сейсмичность // Проблемы эндогенного рельефообразования. - М.: Наука, 1976. С. 259-279.

Хромовских В.С. Разломы и сейсмичность Байкальской рифтовой зоны // Сейсмические исследования в Восточной Сибири. - М.: Наука, 1981. С. 68-87.

Чипизубов А.В., Смекалин О.П. Палеосейсмодислокации и связанные с ними палеоземлетрясения по зоне Главного Саянского разлома // Геология и геофизика, 1999. Т. 40, № 6. С. 936-947.

Чипизубов А.В., Семенов Р.М., Аржанников С.Г., Смекалин О.П. Новые данные о палеосейсмодислокациях в зоне Баргузинского разлома (Байкальская рифтовая система) // ДАН, 2000.Т. 372, № 3.С. 393-396.

Чипизубов А.В. Реконструкция и прогноз изменений сейсмичности Земли. Иркутск: Институт земной коры СО РАН, 2008. - 240 с.

Чипизубов А.В., Смекалин О.П., Семенов Р.М., Имаев В.С. Палеосейсмичность Прибайкалья // Вопросы инженерной сейсмологии, 2009. Т. 36. № 1. С. 7-22.

Чудинов Ю.В. Новейшие тектонические движения в районе бассейна р. Улуг-О и хребта Таскыл в северо-восточной Туве // Бюлл. МОИП. Отделение геологическое, 1959. Т. 34, № 5. С. 55-71.

Шерман С.И. Физические закономерности развития разломов земной коры. Новосибирск: Наука, 1977.- 102 с.

Шерман С.И., Семинский К.Ж., Черемных А.В. Деструктивные зоны и разломноблоковые структуры Центральной Азии // Тихоокеанская геология, 1999. Т. 18. № 2. С. $41-53$.

Active tectonics. Washington, D.C.: Nat. Acad. Press, 1986. -266 p.

Allen C.R. Geological criteria for evaluating seismicity // Bull. Geol. Soc. Amer, 1975. Vol. 86, № 8. P. 1041-1057.

Apel E.V., Burgmann R., Steblov G., Vasilenko N., King R., Prytkov A. Independent active microplate tectonics of northeast Asia from GPS velocities and block modeling. Geophys, 2006. Res. Let. V. 33. L 11303. P. 1-5.

Bonilla M.G. Historic surface faulting--map patterns, relation to subsurface faulting, and relation to preexisting faults, in Proceedings of Conference VIII, Analysis of Actual Fault Zones in Bedrock, 1-5 April, 1979: U.S. Geological Survey Open-File Report 79-1239. P. 36-65. 
Brogan G.E., Kellog K.S., Slemmons B., Terhune C.L. Late Quaternary faulting along the Death Valley - Furnace Creek fault system, California and Nevada // US Geol. Surv. Bull, 1991. № 1991. P. 1-23.

Calais E., Lesne O., Deverchere J., San'kov V., Lukhnev A., Miroshnichenko A., Buddo V., Levi K., Zalutzky V., Bashkuev Y. Crustal deformation in the Baikal rift from GPS measurements / Geophys, 1998. Res. Let. Vol. 25(21). P. 4003-4006.

Cook D., Fujita K., McMullen C.A. Present-day plate interactions in Northeast Asia, North American, Eurasian, and Okhotsk plates // J. Geod, 1986. № 6. P. 33-51.

Chapman M.E., Solomon S.C. North American-Eurasian plate boundary in northeast Asia // J. Geophys. Res, 1976. V. 81. P. 921-930.

Deng Q., Liao Y. Paleoseismology along the range-front fault of Helan Mountains, North Central China // Journal of Geophisical Research, 1996. Vol. 101.№ B3. P. 5873-5893.

DeMets C., Gordon R.G., Argus D.F., Stein S. Current plate motions // Geophys. J. Intern, 1990. V. 101. P. 425-478.

Fujita K., Cambray F.W., Velbel M.A. Tectonics of the Laptev Sea and Moma rift systems, Northeastern USSR // Marine Geology, 1990. V. 93. P. 95-118.

Fujita K., Cook D., Hasegava H., Forsyth D., Wetmiller R. Seismicity and focal mechanisms of the Arctic region and North American plate boundary in Asia // Geology of North America.Vol.L.: The Arctic ocean region / Eds. A.Grantz, J.F Sweeney; Geological Society of America. Boulder, 1990. P. 77-130.

Fujita, K., and Koz'min, B. M. Seismicity of the Amerasian Arctic shelf and its relationship to tectonic features // Proc. Int. Conf. on Arctic Margins., 1992. P. 307-312. / Eds. Thurston D.K., Fujita K., 1994.

Fujita K., Sella G., Mackey K.G., Stein, S., Park K.-D., Imaev V. S. 2004. Relationships between seismicity and GPS determined velocities in northeast Asia (abstr.): Transactions of the American Geophysical Union (Eos), 2004. V. 85(47). Supplement. P. F667.

Fujita K., Kozmin B.M., Mackey K.G. et al. Seismotectonics of the Chersky seismic belt, eastern Russia (Yakutia) and Magadan district, Russia // Geology, geophysics and tectonics of Northeastern Russia: a tribute to Leonid Parfenov, 2009. Stephan Mueller Spec. Publ. 2009. Ser. 4. P. 117-145.

Gaina C., Roest W.R., Müller R.D. Late Cretaceous-Cenozoic deformation of Northeast Asia // Earth Planet. Sci. Lett, 2002. V. 197. P. 273-286.

Grachev A.F. Geodynamics of transitional zone from the Moma rift to the Gakkel ridges. Cont. margin Geol. / Eds. Watkins J.S. and.Drake C.L. // Amer. Assoc. Petrol. Geol. Mem. 33. Tulsa. OK, 1982. P. 103-113.

Huang W., Gao W., Ding G. Neogene volcanism and Holocene earthquakes in the Tanlu fault zone, eastern China // Tectonophysics, 1996. V. 260. P. 259-270.

Imaeva L.P., Koz'min B.M., Imaev V.S. and Mackey K.G. Structural-dinamics analysis of the epicentral zone of the Ilin-Tas earthquake (14.02.2013, Ms =6.9) // Journal of seismology, 2015. P. 341-353.

Kogan M.G., King R.W., Steblov G.M., Lezner-Lam A., Levin V.E. Collision of Eurasian and North American Plates ib Eastern Siberia: Evidence from contininuous and relative GPS // Fall meeting American Geophysical Union, 1998. P. 218.

Kogan M.G., Steblov G.M., King R.W et al. Geodetic constraints on the rigidity and relative motion of Eurasia and North America // Geophys. Res. Lett., 2000. V. 27. N. 14. P. 20412044. 
Kumamoto, T. Long-term conditional seismic hazard of Quaternary active faults in Japan // J. Seismol. Soc. Japan. 1998. 50. 53-71.

Mackey K.G., Fujita K., Gunbina L.V., Kovalev V.N., Imaev V.S., Kozmin B.M., Imaeva L.P. Seismicity of the Bering Strait region: Evidence for a Bering block // Geology, 1997. V. 25. P. 979-982.

Mackey K.G., Fujita K., Gounbina L., Koz'min B., Imaev V., Imaeva L., Sedov B. Explosion contamination of the northeast Siberian seismicity catalog: implications for natural earthquake distributions and the location of the Tanlu fault in Russia // Bull. of the Seismol. Soc. of Amer. 2003. V. 93. P. 737-746.

Mackey K., Fujita K., Hartse H.E. et al. Seismicity of Eastern Russia 1960-2007: map, 2007. LAUR-04-1381.

Molnar P., Tapponier P. Cenozoic tectonics of Asia // Science, 1975. V. 189. P. 418-426.

Moores E.M. and Twiss R.J. Tectonics / W.H.Freeman and Company. New York, 1995. $415 \mathrm{p}$.

Nikonov A.A. Active faults: Definition and identification problems // Research on active faults, 4. Beijing: Seismol. Press, 1995. P. 140-152.

Paleoseismology / Edited by J.P. McCalpin. - San Diego: Academic press, 1996. - 585 p.

Plate-tectonic map of Circum-Pacific region.Circum-pacific map series / U.S. Geological Survey. Washington, 1984.

Qidong D., Peizhen Z. Research on the geometry of shear fractures zones // Journ. Geophys. Res, 1984. V. 89. № 137. P. 5699-5710.

Reid H.F. The California earthquake of April 18 1906. Vol. $2 / /$ The mechanics of the Earthquake: Rep. of the State Invest. Com. Wash.: Carnegie Inst. Publ., 1910. 87. Vol. 2. - 192 p.

Riegel S.A., Fujita K., Koz'min B.M., Imaev V.S., Cook D.B. Extrusion tectonics of the Okhotsk plate, northeast Asia // Geophys. Res. Lett, 1993. V. 20. P. 607-610.

Rowley D.B., Lottes A.L. Plate-kinematic reconstructions of the North Atlantic and Arctic: Late Jurassic to Present // Tectonophysics, 1988. V. 155. P. 73-120.

Sanders C.O., Slemmons D.B. Geomorfic evidence for holocene earthquakes in the Olinghouse fault zone, Western Nevada // Bull. Seismol. Soc. Amer, 1996. V. 86. № 6. P. 1784-1792.

Savostin L.A., Karasik A.M. Recent plate tectonics of the Arctic basin and Northeastern Asia // Tectonophysics, 1981. V. 74. P. 111-145.

Sella G.F., Dixon T.H., Mao A. REVEL: A model for Recent plate velocities from space geodesy // J. Geophys. Res, 2002. V. 107. - 27p.

Shebalin N.V., Ulomov V.I., Tatevossian R.E., Trifonof V.G., Loffe A.I., Kozhurin A.I. Unified Seismogeological Taxonomv of the Northern Eurasia. IUGG-Abstracts. SB21C-14. Boulder. - U.S.A, 1995.

Shebalin N.V., Trifonov V.G., Kozhurin A.I. et al. A unified seismotectonic zonation of Northern Eurasia // J.Earthquake Predict. Res, 2000. Vol. 8, № 1. P. 8-31.

Sieh K.E. Prehistoric large earthquakes by slip on the San Andreas Fault at Pallett Creek, California // J. Geophys. Res, 1978.Vol. 83, № B8. P. 3907-3939.

Slemmons D.B. and dePolo C.M. Evaluation of active faulting and related hazards. In Active Tectonics. Studies in Goephysics (R.E. Wallace, chairman). - Natl. Acad. Press, Washington, DC, 1986. Pp. 45-62.

Sylvester A.G. Strike-slip faults // Geol. Soc. Amer. Bull., 1988. V. 100. №. 11. P. 16661703. 
Tapponier P., Molnar P. Active faulting and Cenozoic tectonics of the Tien-Shan, Mongolia and Baykal // Journ. Geophys. Res, 1979. V. 84. N B7. P. 4325-3459.

Trifonov V.G. World map of active faults. Quarter. Internat. Spec. Issue, 1995. № 25. P. $3-16$.

Ulomov V.I., Shumilina L.S., Trifonov V.G. et al. Seismichazard of Northern Eurasia // Ann. Geofis, 1999. V. 42, № 6. P. 1023-1038.

Wallace R.E. Structure of a portion of the San Andreas rift in southern California // Bull. Geol. Soc. America, 1949. V. 60, № 4. P. 781-806.

Wallace R.E. Profiles and ages of young scarps, North-Central Nevada // Bull. Geol. Soc. America, 1977. V. 88. P. 1267-1281.

Wallace R.E. Degradation of the Hebgen Lake fault scarps of 1959 // Geology, 1980. V. 8. P. 225-229.

Wallace R. E. A perspective of paleoseismology // Direction in paleoseismology.Open file report 87-673. Denver, Colorado, 1987. P. 7-16.

Wells D.L., Coppersmith K.J. New empirical relationships among magnitude, rupture length, rupture width, rupture area, and surface displacement // Bull. Seismol. Soc. Amer, 1994. V. 84, № 4. P. 974-1002.

Yeats R.S., Sieh K., Allen C.R. The Geology of Earthquakes.Oxford university press, 1997. $-568 \mathrm{p}$.

http://www.ceme.gsras.ru (сайт Геофизической службы РАН)

http://earthquake.usgs.gov/earthquakes/

http://earthquake.usgs.gov/ earthquakes/pager/events/us/c0007dax/index

http://earthquake.usgs.gov/earthquakes/ pager/events/us/b0008672/index.html

http://www.scgis.ru/russian/cp1251/h_dgggms/1-2003/screp-8. pdf

http://www.scgis. ru/russian/cp1251/h_dgggms/1_2003/screp_7.pdf

http://www. scgis. ru/russian/cp1251/h_dgggms/1_2003/screp_6. pdf

http:// www.seismos-u.ifz.ru/

http://pubs.usgs.gov/of/1979/of79-1239/

www.USGS.gov 


\title{
Научное издание
}

\author{
Имаева Людмила Петровна \\ Имаев Валерий Сулейманович \\ СмекалинОлег Петрович \\ Козьмин Борис Михайлович \\ Гриб Николай Николаевич \\ ЧипизубовАнатолий Васильевич
}

\section{КАРТА СЕЙСМОТЕКТОНИКИ ВОСТОЧНОЙ СИБИРИ}

Технический редактор Л.В. Николаева

Подписано в печать 03.07.2015. Формат 60x84/8.

Бумага тип. №2. Гарнитура «Таймс». Печать офсетная.

Печ. л. 8. Уч.-изд. л. 10. Тираж 350 экз. Заказ №

Издательство ТИ (ф) СВФУ, 678960, г. Нерюнгри, ул. Кравченко, 16.

Отпечатано в МУП «Нерюнгринская городская типография».

г. Нерюнгри, ул. Северная, 8. 